
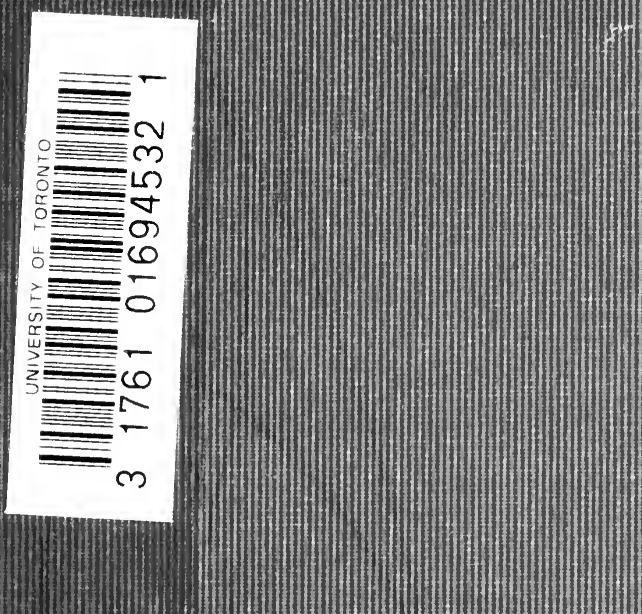
, 
4.5 

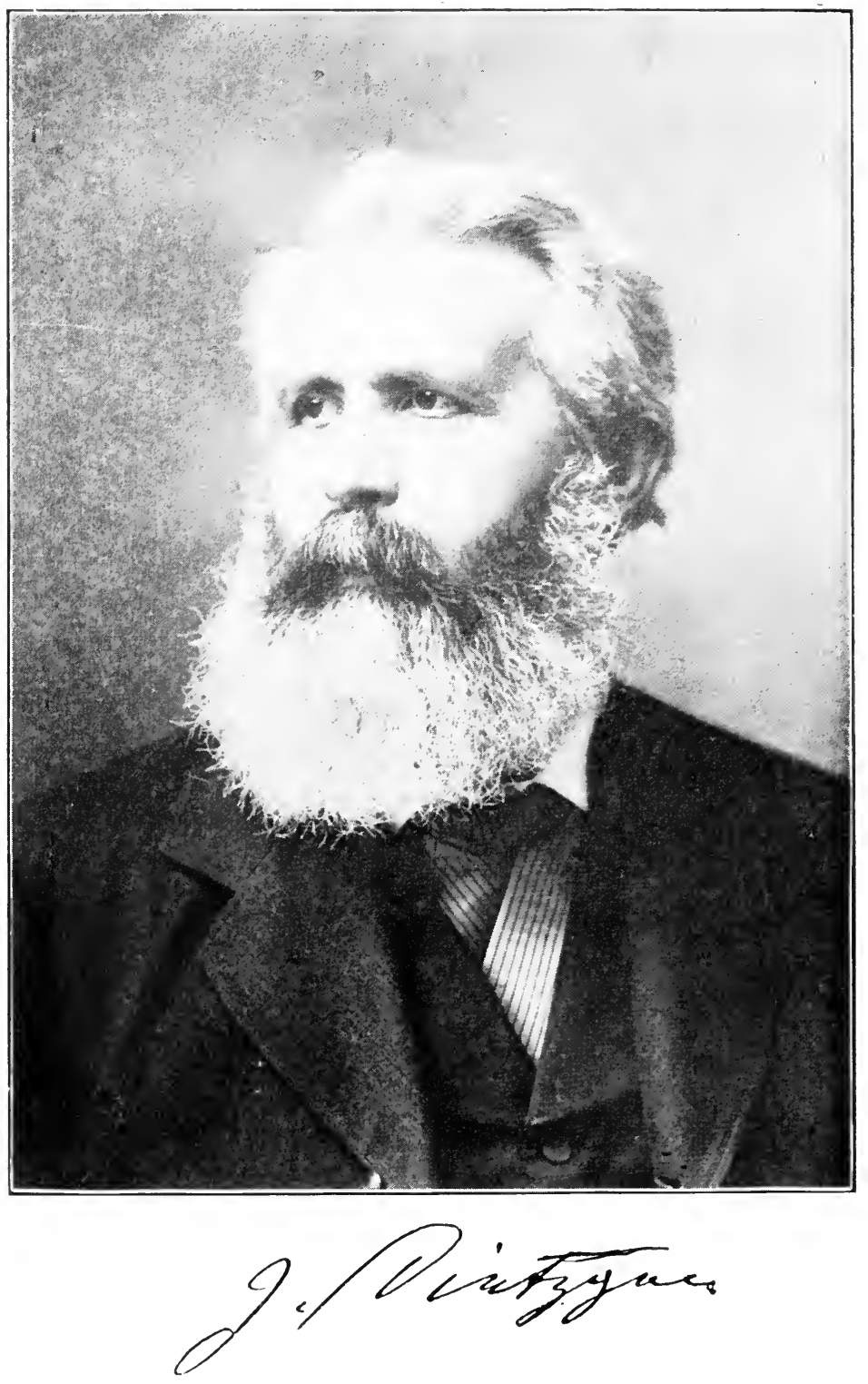
SOME OF THE

\section{PHILOSOPHICAL ESSAYS}

ON

Socialism and Science, Religion, Ethics,

Critique-of-Reason and the

World-at-large

\section{BY \\ JOSEPH DIETZGEN.}

TRANSLATED BY M. BEER ANU TH. ROTHSTEIN

WITH A BIOGRAPHICAL SKETCH AND SOMN INTRODUCTORY RRMARKS BY WUGENE DIGTZGEN: TRANSLATED BY ERNEST UNTERMANN.

FDITED BY DUGENE DIETZGEN AND JOSEPH DIETZGEN, JR.

\section{CHICAGO}

CHARLES H. KERR \& COMPANY

CO-OPERATIVE 
COPYHight 1906

By Eugene Dietzgen

$$
\text { काivis } 3
$$

pinios

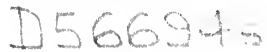

(अ)

19.3 .57 


\section{TABLE OF CONTENTS}

Joseph Dietzgen: a Sketch of His Life by Eugene DietzGen . . . . . . . . . . . . . . . . 7

An Illustration of the Proletarian Method of Research and Conception of the World: Max Stirner and Joseph Dietzgein. By Eugene Dietzgen . . . . . 35 Scientific Socialism . . . . . . . . . . 79 Thie Religion of Soctal-Democracy . . . . . . 90 Ethics of Social-Democracy . . . . . . . . . 155 Social-Democratic Philosophy . . . . . . . . . 173 The Limits of Cognition . . . . . . . . . . . 224 Our Professors on the Limits of Cognition . . . . . 236 The Inconceivable: a Spectal Chapter in Soctal-Democratic Philosophy . . . . . . . . . . . 254

Excursions of a Socialist into the Domain of Epistemology

Preface . . . . . . . . . . . . . . . 263

I. "The Innermost of Nature No Created Mind Can Enter" . . . . . . . . . . . . . . 266

II. The Absolute Truth and Its Natural Manifestations 278 III. Materialism versus Materialism . . . . . . . 29I IV. Darwin and Hegel . . . . . . . . . . . 314

V. The Light of Cognition . . . . . . . • • 342 


\section{JOSEPH DIETZGEN}

A SKETCH OF HIS LIFE BY EUGENE DIETZGEN 1

My father, Joseph Dietzgen, was born in Blankenberg, near Cologne, Germany, on December 9, 1828. The place is a former stronghold of a robber baron, romantically situated. A part of the walls and four massive ruins of towers of the old stronghold still lend a picturesque character to the landscape, the effect being heightened by the location of Blankenberg high upon a mountain covered with woods and vineyards, at the foot of which the Sieg, a charming tributary of the Rhine, winds its way.

My grandfather, who was a well-to-do master tanner and a genuine little bourgeois, transferred his tannery, about the year I835, to the nearby village of Uckerath, a place of about four hundred inhabitants. It owed its relatively busy life to the fact that it was a relay station on the postal route between Francfort and Cologne, which was then much frequented.

My father was the eldest of three brothers and two sisters and resembled more than any of them his mother, a woman of high endowment, who at the age of 74 still attracted attention by her beautiful and stalwart appearance. The Dietzgen's were one of the oldest families in the valley of the Sieg, and the chronicle of the county seat Siegburg mentions some Dietzgen's in the

${ }^{1} A$ revised and completed reproduction of an article in "Die Neue Zeit," 1894-95, Vol. II. 
capacity of civil councillors and master tradesmen as far back as 1674 .

My father went to the public school in Uckerath, and later on for a short time to the high school in Cologne. $\mathrm{He}$ is described as being, up to his fifteenth year, an exceptionally bright boy, always up to some pranks and giving much trouble by his high spirits to the pastor, the mayor, and other prominent citizens of Uckerath and its neighborhood. For this reason, my grandfather sent him for a short while away from Uckerath to the Latin school of a very strict disciplinarian pastor in the village of Oberpleis.

However, his years of adolescence and the awakening of love's longing made a thoughtful young man of him, who in the hours of recreation from tanning in grandfather's shop assiduously studied literature, political economy, and philosophy. He derived some inspiration Irom the companionship of a playmate of his childhood who attended the university at Bonn.

In those days, $1845-1849$, in the shop, where a book was generally found open by the side of his work, he also learned to read French fluently without a teacher and to speak it so well that in 1871 , when French prisoners of war were quartered in the town of Siegburg where we lived at that time, he was able to converse with them, while to my surprise the teachers of French in the preparatory college could not do so. A small number of poems of my father, dating from his period of adolescence, 1847-1851, were found among the papers left by him. I reproduce two of them herewith:

\section{THE PROLETARIAN.}

By chains of poverty my life is bound, And superstition's mists obscure my brain. 
The curse of toil, the never-ending strain, Oppresses me and weighs me to the ground.

Made in a mould divine, yet I was found Amid the filthy garbage of a drain, The offspring of the outcast and profane, Doomed to the level of a soulless hound.

A vagabond! Sufficient for my kind The beggar's meal, doled out from day to day With drops of hollow faith to ease my mind.

Bear I my cross until this mortal clay Shall totter to its grave? Where will you finc My soul? Where Satan holds eternal sway!

$$
\text { HARD TIMES. }
$$

Little woman, little song, Oh, I love you, love you long.

-Fr. v. Schleges

In my good young days of gladness, When I felt my nature thrilling With creation's sweetest madness, Maidens fair were always willing, And there was no room for sadness.

In my happy exultation, And 'mid kisses, songs, and dances,

I defied with animation

Care's and worry's darkest glances.

Woe is me! The tide has turned!

Times have changed. Now frank devotion, Tender glances, sweet embraces, Conjure up the marriage notion, Altar, wedding-ring, and laces, And a family commotion.

Sadly do I face the question:

Why is love abomination,

Why a shame the sex suggestion, 
Unless bless'd by rank and station?

Woe is me! The tide has turned!

Pretty maiden, bright and bonnie, Winsome, charming, blithe and rosy!

If I only had the money For a homestead snug and cosy, You would be my bride, my honey! But, alas! though Cupid's craving Is as wild and strong as ever, Yet in vain is all my raving. Never shall I hold you, never!

Woe is me! The tide has turned!

At an early stage of his development, my father felt attracted toward Socialism-aside from the lessons taught by the times and conditions in which he lived by the study of the French economists; the Communist Manifesto of Marx and Engels made a class-conscious socialist out of him in 1848 .

'He tried his hand at the trade of a "preacher of discontent" in the "mad" year 1848 , by addressing the peasants from a chair standing in the main street of the village.

In June, I849, the reaction drove him to America, at the age of 2I. There he worked for two years as journeyman tanner, painter and teacher, but only at intervals, spending most of his time as a so-called tramp without means, and walking, or riding on canal boats, over a large part of the United States, from Wisconsin in the North to the Gulf of Mexico in the South, and from the Hudson in the East to the Mississippi in the West. Apart from acquiring the English language, he regarded as the best result of these travels, as he wrote to me to New York in r882, "the feeling of having become acquainted with a land and with conditions, where 
one can make light of the pressing care for the daily bread which weighs upon one so hard in Germany."

In December, 1851, we again find him at work in grandfather's shop at Uckerath, and two years later he married a devoutly religious orphan from the little country town of Drolshagen in Westphalia. Her goodness of heart and love of life cheered him, until her death in 1877 made him a widower.

In spite of their utterly different mental propensities my mother having the prejudiced bourgeois mind and being a devout Catholic, while my father was a thoroughgoing naturalist and proud of his proletarian convictions - they lived in rare harmony.

It is significant for the relations of my parents that even after twenty-one years of union with my father, my mother urged me on the occasion of my first communion, which seemed to her an especially opportune moment, to send the fervent prayer to God that he might convert my father and lead him back into the embrace of the alone-saving church. Although this prayer. remained unfulfilled, my father nevertheless occupied the place next to God in the devotion of my mother throughout all her life.

Shortly after his marriage, my father opened a grocery store, a bakery, and a tannery combined in the nearby Winterscheid, much after the manner of the enterprising Americans. He was so successful in his business that he soon opened a branch store in the village of Ruppichteroth. But as was his custom in Uckerath, so also in Winterscheid and in his later enterprises my father devoted only half of the day to material gain, while the rest of his time was spent in diligent study, from pure thirst of knowledge and without other incentive.

In order to secure economic independence for himself 
and to be enabled to devote himself entirely to science at an earlier date than would have been possible by the help of his country store, he again emigrated in 1859 to the United States, where he tried to establish a larger business in the South. But the Civil War breaking out soon after that, his business in Montgomery, Alabama, came to an end. One morning he found some of his friends strung up in front of their houses, because their sympathy for the North had become inconvenient to their neighbors. He left Alabama in 1861 and returned to the Rhine, where he took charge of grandfather's tannery which he operated, as the grandfather had done, with the occasional help of a day laborer.

It happened one day that his eldest sister called his attention to an advertisement in the "Kölnische Zeitung," in which a man familiar with advanced methods of tanning was wanted for a large government tannery in St. Petersburg, Russia. My father applied for this position, and in the spring of 1864 the Russian counsellor of state, Goureaux, visited him in Uckerath and engaged him at a high salary. In a few years, my father succeeded in increasing the productivity of the establishment fivefold, by the introduction of improved machinery and methods. But in 1869 he was back once more in the Rhineland, this time at Siegburg, where he had inherited a tannery from one of his uncles. It was this inheritance, together with his desire for greater independence, and the political conditions of Russia, that induced him to leave St. Petersburg. The administration regretted his departure and promised to continue his salary, if he would inspect the factory for a few months every year. My father visited St. Petersburg several times for this purpose, but later the administration decided to dispense with his costly services. 
During his sojourn in Russia, my father wrote his first work: The Nature of Human Brain Work, discussed by a workingman. A renewed critique of pure and practical reason. This critique of reason first appeared in 1869, published by Otto Meissner in Hamburg. It contains for the careful reader, among other things, an epistemological confirmation and explanation of the consistency of the materialist conception of history, on the basis of the monist-naturalist theory of understanding; furthermore, the beginning of a dialectics developed beyond Hegel and his successors, Feuerbach, Marx and Engels.

However, Joseph Dietzgen formulated his discovery of a dialectics expanded into a cosmic-monistic philosophy more clearly and usefully in his "Positive Outcome of Philosophy" which appeared in 1894 . In this work his dialectics is more definitely and perfectly elaborated, not only as the "science of the general movement and development of nature, of human society, and of thought" (Engels), not only as the science of the eternally changeable diffusion of things, the individual connections of which must be studied, but also as the science of the infinitely constant and monistic interrelation of all things in the universe. It was only by means of this perfection that dialectics could grow into a consistent monism, a uniform world philosophy. From this moment dates the discovery of a cosmic-dialectic method of thought which guarantees a strictly systematic and logical uniformity in the theory of all studies, no matter how wide and irreconcilable may seem the contradiction of the questions treated. This is the only method of research which exterminates dualism and superstition in all fields of studies, and clears the road for every science to its very last conclusions where each science merges into the universal 
interrelation of nature. These words may here suffice to indicate the principal accomplishment of Joseph Dietzgen.

In St. Petersburg, he also wrote his articles on "Capital," by Karl Marx, which appeared in the "Demokratische Wochenblatt," at Leipzig, in 1868, which paper was the precursor of the "Volksstaat" and the present Berlin "Vowärts."

Karl Marx makes a highly commendatory reference to the economic understanding of my father in the preface of the second edition of the first volume of "Capital." $\mathrm{He}$ also visited my father in Siegburg.

At this point I must remember another friend of my father's, who deeply influenced his mental development. This is Ludwig Feuerbach, with whom my father entertained a correspondence. When in 1871 the news of the poverty and death of this philosopher reached my father, I remember seeing him cry for the first time.

His small tannery in Siegburg permitted him to study with little interruption, since he did not care to accumulate material wealth, his Siegburg heirloom guaranteeing in a modest way the necessities of life for himself and family, so long as it was kept together. That he did not succeed in keeping this heirloom intact, was a cause of much subsequent trouble to my father. There were al. ways a great number of friends who needed assistance that injured him. In one case he went to Denmark in order to assist a comrade financially in his tanning business. But the attempt failed, with great loss to himself. At the same time, his leather store and tannery in Siegburg were less and less able to compete with the growing great capitalist industries and to yield profits. Finallv his last customers were almost wholly lost when he was taken into custody for three months, pending his trial 
in Cologne, in 1878 . This arrest was made under the influence of the momentary excitement which had seized the German authorities after the attempt of Hödel and Nobiling, in 1878 , to kill the German emperor. The direct cause of his arrest was a speech on "The Future of the Social-Democracy" which he had delivered in Cologne. This speech appeared in print in Cologne in 1878 and many new editions of it are being used up to the present for propaganda.

During his stay in Siegburg from 1869 to 1884 , my father wrote a large number of articles on economic and philosophical questions for the "Volksstaat," Leipzig, 1870-1876; "Vorwärts," Leipzic, 1877; " Sozialdemokrat," Zürich, I880-I888; “ Neue Gesellschaft," Zürich ; " Neue Zeit," Stuttgart; "New Yorker Volkszeitung," New York, and a number of pamphlets. I am familiar with the following: "The Religion of Social-Democracy" (five sermons, Leipzic), "Bourgeois Society," Leipzic; "Thoughts on Political Economy," Leipzic; “An Open Letter to Heinrich von Sybel," Leipzic; “The Faith of the Faithless," Solingen.

At the international congress at The Hague, in 1872 , to which my father was a delegate, Karl Marx introduced him to the assembled delegates with the words: "Here is our philosopher."

In spite of his reluctance, due to his lack of training and, perhaps, also to lack of talent for parliamentary functions, he was induced in I881 to accept a nomination for the Reichstag in the county of Leipzic. However, he was beaten by a coalition of the parties of "law and order." In I880, when his Siegburg business had been undermined and his means reduced by half by unfortunate relatives and friends, he suggested to me, his eldest son, after completing my studies at the Siegburg "gymnasium," to 
emigrate to the United States and to become the pathfinder for the existence of our family. After luck had favored me in this respect, my father was enabled to devote himself in peace to his life's work, which unfortunately was cut short prematurely when he had just completed his "Positive Outcome of Philosophy."

How seriously he took his task, may be inferred from statements made before his death and from the following letter to me, written October 16, 1880:

"An essential part of myself, the existence of which you may have suspected intuitively, but which you cannot really know, because we have never spoken of it, since you were too young, shall now be revealed to you. It will enable us to understand one another still better. To come to the point: I have been haunted since the days of my youth by a logical problem, viz., that of the "last questions of all knowledge.' It presses on my brain like a stone. Whenever in the course of past years the cares of providing for the necessities of life were urgent, I might forget about it for a few years. But as soon as matters would go along more smoothly, it would always return, ever stronger and clearer, until finally of recent years $I$ have come to the conclusion that this is the work of my life. My peace of mind as well as my moral duty demand that I should devote myself to it and accomplish it. If $I$ had been aware of this in St. Petersburg as I am now, we might still be there. This is the reason why $I$ have been continuously striving to find an associate who would help me to carry the economic burden. Hence we have had that experience in Denmark and Solingen (he had made an unlucky venture in leather also in Solingen), and for the same reason I cannot carry on my little business here without help. My efforts are always directed toward the end of keeping 
my brain disengaged from business, so that I may occupy myself with my problem. For the last years I have had a hard time of it, for this problem rises with me and goes to bed with me, and the material cares do not permit me to pay much attention to it. Let this be enough for the present. I cannot say much about the subject itself, until you have become more mature. J. H. von Kirchmann, the publisher of the 'Philosophische Bibliothek,' names as the first requisite for the pursuit of philosophy a life rich in experience and events, a life that has seen much, tasted every happiness and every pain, and done and suffered right and wrong.

"Now I want to impress you with the desirability of genuine culture. Above all, do not forget, while in America, that one should do business for the sake of life, not live for the sake of business. Never be harsh in your judgment of others, but make allowance for their environment. In order to be able to act courteously, you must think courteously. Virtue and faults are alway: combined. Even the rascal is a good fellow, and 'the just sins seven times per day.' Now enjoy life and work bravely."

The private letters which my father used to write me regularly every week or two from the time of my emigration in May I880 up to his third landing in America in June 1884 , I have collected in one volume. They may interest a wider circle, not only on account of the deep insight which they afford of the soul-life and character of my father, but also on account of the wisdom of life and invaluable guides for the development of young and inexperienced people contained in them.

My father wrote two series of letters on logic during the period 1880-1883. But only that dealing with a critique of the theory of understanding was published 
by Dietz in Stuttgart in 1895, together with the "Positive Outcome of Philosophy." Of the series dealing with economics, only the first seven letters appeared in print, in the "Sozialdemokrat" (Zürich, I883-84). In reference to these letters, he wrote me on November 7 , 1883 :

“. . . Sorge will be more interested in these last three letters of the economic series than in the first series which is philosophical. For my part, I think more of the logical than the economic element, since what I have to say on the art of thinking is, so to speak, my own work and discovery, while I received my understanding of economics ready made from Marx."

In the beginning of the eighties, my father was frequently visited by a number of students of the university in Bonn, among them Dr. Bruno Wille, who published, in the April number, 1896 , of " Der Sozialistische Akademiker" (Berlin) his impressions in these words:

"When I inquired in pleasant Siegburg for the home of Dietzgen, I was shown a little house covered with vines and situated in the middle of a garden on the bank of a creek. Skins soaking in water and the smell of oak bark indicated the presence of a tannery. A pretty girl of tall stature showed me into the parlor and called her father. The cozy room bore evidences of the literary inclinations of its owner, being filled with books which were plainly more than mere articles of decoration. There was also a portrait of Béranger.

"Dietzgen entered and saluted me cordially. He was a man of giant stature, whose strength and animation did not betray his 54 years, although his luxuriant beard was grey. The first glance at his noble features convinced me that here was a man of genius. His large fiery eyes recalled the well-known potraits of Goethe. His beauti- 
ful forehead bore the imprint of the placid serenity of the antique philosophers. His manliness was combined with a loving and tender mind. His cordial sociability and the endearing melodiousness of his speech announced the best type of the Rhinelander. His voice sounded metallic, with a little nasal twang. Dietzgen came direct from his work in the shop, and he was not in the least embarrassed by meeting his visitor in his shirt sleeves. Thus he was an ideal illustration of the title of his first work, "The Nature of Human Brain Work, by a working man.'

"Dietzgen made ready for a walk with me. He abandoned his tannery without any ado. He carried it on only so far as it was required to maintain his modest household. This philosopher did not feel inclined to be a slave of work for gain. I discovered by his very first sentences that he was perfectly at home in the regions of higher mental life. Not a trace of the dust of the shop was on his soul. No professor could rise from his desk more spiritualized than this tanner did from his manual labor. In a few minutes, we were deeply engaged in a discussion of philosophical books and problems. I was surprised at Dietzgen's expert knowledge and general education, which was calculated to put to shame those conceited intellectuals who look down with disdain on the man without a university training. This philosophical working man had even occupied himself with antique literature, and with better success than is generally shown by a graduate of a college, in spite of the fact that he was not familiar with Greek and only a beginner in Latin. When on a later occasion I visited him with a student who excelled in history, Dietzgen proved himself qualified to discuss with the greatest understanding a rather obscure special question of history. Such evi- 
dences of knowledge and mental superiority were given with extreme naturalness and simplicity, in which there was not an atom of that boastfulness which I have not unfrequently observed in self-educated men. Dietzgen was far too objective and wise to pose.

"While I was in Bonn, my pilgrimages to Siegburg were one of my favorite pastimes. As a rule I brought with me some books from the library of the university for Dietzgen. Sometimes I was accompanied by my student friends. And I learned to love the workingman philosopher more and more. The versatility, strength and freshness of his talents were as inspiring as the oak tree distinguished by the luxuriance of its trunk, branches and foliage. Dietzgen was not a one-sidedly abstract and sober nature. His finely and sharply chiseled mental life was imbued with a certain poetic quality. His eye sparkled when resting on the beauties of nature during our walks. He was fond of poetry, especially of lyrics, which are generally neglected by inartistic minds. Once he recited for me a translation of a poem by Burns which he had clad in well-rounded German verse. If I am not mistaken, he then told me that he had paraphrazed several poems by Burns and Béranger. His mind had remained young in spite of his years. With joyful humor, fraternizing and freely conversing without restraint, he would sit among us young and frivolous folk drinking beer or punch. But he always held aloof from the trivial and maintained a mental level which compelled the respect of even the most forward. Otherwise, as a citizen of Siegburg, he led a rather lonely, almost hermit-like, existence. The bourgeois were not to his liking. Moreover, they had a certain distrust of Socialism, especially the officials. He had little intercourse with comrades of the party, though there were quite a number of them in 
nearby Cologne. He seemed to feel no attraction for party life. He told me that he had given a few lectures in party meetings, and, if I am not mistaken, that he had been nominated for the Reichstag, but declared that he was no speaker and no politician. In his pleasant way, he related his experience with the authorities. Shortly after Hödel's attack on the emperor, he accepted an invitation of comrades of the party and gave a lecture on 'The Future of the Social-Democracy' in Cologne. His manuscript was published in pamphlet form under the same title. In his own words: "In the meantime the second attack, that of Nobiling, had occurred, whereupon the uniformed, decorated, titled and official world of Germany leaped up as if bitten by a tarantula. They confiscated my pamphlet, handcuffed me to another vagabond, and delivered both of us on the eve of Pentecost to the prison of Cologne. After keeping me there for two months, they dragged me, together with the editor of the "Neue Freie Presse" and my Friend Kröger, who had committed the dangerous crime of acting as agent for my pamphlet - I don't know what - incited class against class, desecrated religion, endangered the public peace, etc., etc. After the court had dismissed us without any penalty and costs, I was again handcuffed by the gensd'armes and led to my cell. The public prosecutor had appealed the case. And when the second trial once more ended in my acquittal, the obstinate prosecutor appealed again, this time to the court of cassation in Berlin, where the author and his pamphlet were at last set free. A few days after that the anti-socialist laws put a radical end to all freedom, and the authorities gave me the documentary assurance that the future of the Social-Democracy was forbidden. Did not Xerxes whip the sea when it was rough? Now let the Prussians go 
ahead with their whipping. The Social-Democracy will attend to its own future." "

For the third time, my father emigrated to the United States in June, I884. Soon after his arrival he accepted the editorship of the newly founded party organ in New York, "Der Sozialist," which he retained until he moved to Chicago, in I886, at my solicitation, with my two sisters and one brother. One of his daughters, who had married in Russia was the only one of the family remaining in Europe.

In Chicago, my father wrote in 1886 a work of 60 pages, entitled "Excursions of a Socialist into the Domain of Epistemology," which was published in 1887 by the People's Book Store in Hottingen-Zürich. In 1887, he wrote "The Positive Outcome of Philosophy."

When in 1886 the editors of the "Chicagoer Arbeiterzeitung" were arrested, to be condemned to death a year later in the well-known anarchist trial, my father temporarily assumed the post of chief editor and remained a contributor to this paper up to the time of his death.

At this point, I should like to insert a few statements about my father which F. A. Sorge, the intimate friend of Marx and Engels, and the Nestor of the American socialist movement, published in the Pioneer Calendar of the "New-Yorker Volkszeitung," in I902:

"When he came to America for the third time, he rented, in a remote part of North New-Jersey, an old, almost dilapidated, house which was barely habitable. and there he felt quite satisfied, although visitors trod with misgivings on the steps of the rickety stairs which led to his rooms. In 1884 , he wrote to a friend in regard to "the Marxian statement . . . that economics is the basis (also for the individual) on which the mental superstructures are reared. Our world desires to live, to 
eat and drink in a civilized style, even though it be barbarian inside. But for my part, I can be at ease in barbarian surroundings, provided my private economy is arranged so that I can devote myself without care to the superstructure."

Speaking of a proposed trip to Germany, he says in a letter of November 27, 1887: "I shall travel in the steerage, because a man who does not make any money has to turn his pennies over three times, before he spends them. Besides, I feel more at home in a humble role than on the high horse."

His simplicity of living made him by no means morose or indifferent to the things of the outer world. That he enjoyed life and work is clearly shown by the following letter to a friend of his youth, who lived in New York:

SiegBurg, September 25, 1869.

. . I I have returned from Petersburg to the scenes of my childhood, on the banks of the Sieg, have built huts in Siegburg, and am tanning the skins of the people. It occurs to me to express the wish that you might likewise be so strongly attracted by the home recollections that you leave the Hudson and the American chase after the dollar and come home with your better half and the material products of your loins, in order to dig for treasures which neither the rust nor the moths corrupt, that is, the general truths of science and of the historical evolution of the human race. Although man, according to Karl Vogt, is descended from monkeys, he is nevertheless the sublime object.

At Otto Meissner's, the well-known embryo of my youth, the child which I have long carried under my heart, has at last been born. It has been baptized with the name of "The Nature of Human Brain Work, Discussed by a Working Man. A Renewed Critique of Pure and Practical Reason," and the preface is signed "Joseph Dietzgen, Tanner." I commend it to you.

Another event which moves my heart and which will interest 
you is a visit which was paid to me about fourteen days ago by our venerated hero, Karl Marx. He stayed a few days in Sieburg with his charming daughter. Joseph Dietzgen.

Personally, Joseph Dietzgen was a tall and handsome man, who strikingly resembled the oft-described figure of Goethe, symmetrically built and of noble and unaffected bearing, with a frank and open eye full of intelligence and goodness. His whole being inspired respect and veneration. He went almost too far in his modesty and unselfishness, especially in his relations with the publishers of the "Sozialist" in New York, the National Executive of the Socialist Labor Party, who made life very unpleasant for him while he acted as editor of their paper. But with all his modesty and unassuming bearing, he still showed manliness and true courage. While the National Committes, after the throwing of the bomb at the Haymarket in Chirago, thought only of repudiating all connection with the anarchists, and with anarchism, Dietzgen, in the very midst of lawlessness of the heroes of "law and order," went to the persecuted and reviled and offered them his help and comfort in the hour of their need. It required real courage and strength of character to do so at that time. It was a purely humane and manly act on his part, for which the Chicago police rewarded him by searching his house and scaring his children.

One of the contributors to the "Chicagoer Arbeiterzeitung" of that period described Joseph Dietzgen's actions and bearing in those times as follows: "When in May, 1886, the waves of the labor movement began to rise, when the Haymarket bomb had exploded and the reaction followed with a police rule similar to that of Russia, when cautious and soberminded men censidered 
it well to deny any connection with the arrest of editors of the "Arbeiterzeitung," an old gentleman introduced himself, on May 6, to those of the publishers who had not preferred to take to the woods. He offered them his services, because he considered it his duty to jump into the breach and fill the place of those comrades who had been torn out of the ranks of the fighters, and because he considered it necessary that the Chicago workers should not be without an organ in those trying times.

This old gentleman, of giant stature, with the bearing of a patriarch, such as we see in good old pictures, was Joseph Dietzgen, who had shortly before joined his children in the young metropolis, in order to pass the remainder of his days in the circle of his adoring family. It was the same Dietzgen who had often been reviled and ridiculed in this Chicago paper by Spies and his companions, in a spiteful controversy, which, starting from a principle, had been directed by them against the unknown personality and sometimes old-fashioned and ornamental style of Dietzgen.

That this offer of Dietzgen's, who asked no pay for his services, and did not expect any, was brave and unselfish, was not only admitted by those to whom he had made it, but was also admired and appreciated by all who learned of it then and later. His offer was accepted, and when two weeks later the administrative board of the Socialist Publishing Society convened, they elected Dietzgen unanimously to the position of chief editor of the three papers published by this society, "Arbeiterzeitung," "Fackel," and "Vorbote."

When the new editor in chief assumed control, he made the following little address to the employees which is typical of the whole man: "Gentlemen: I have beer elected chief editor of your papers. If this position re 
quires the duties of an overseer or driver, then I am not fit for it. I shall confine myself to the writing of my articles. It is said that there is no harmony in this office. Well, if you can have confidence in me, I shall be pleased to have you present your differences of opinion to me. I shall then try to act as arbitrator and to establish peace."

Well, the dissension was not so very great, but the editorial staff learned to have confidence in their chief and to venerate him like a father. This relationship remained undisturbed, although Dietzgen did not stay in his position very long, but resigned his title and was satisfied to contribute articles up to the time of his death in April, I888. Being almost too modest and avoiding publicity with excessive bashfulness, he became very little known personally in Chicago. But all who were fortunate enough to become acquainted with him, loved the man and respected his character."

And Sorge continues: "Dietzgen was assailed by friend and foe for his stand in defending the prisoners and taking editorial charge of the 'Chicagoer Arbeiterzeitung, during the prosecution of Spies and his comrades. He tried to lessen the differences between socialists and anarchists ${ }^{1}$ by emphazing that which was common to both, in accordance with the requirements of a cultivated use of the intellect which teaches that 'there are only differences of degree, not radical differences, not absolute differences between things. Contradictions are

\footnotetext{
1 Wherever we mention anarchists, it should be remembered that wa refer to the Chicago anarchists, so-called "communist anarchists," wbr were no individualists, but sincere, though very radical and theoreti all. unclear proletarian revolutionaries. It was these men whom my fatio tried to win back for the socialist labor movement, not individuah. anarchists, as was thought by comrades in New York and Europe.
} 
solved by reasonable distinctions,' he says in his 'Positive Outcome of Philosophy." "

To a friend in the East of the United States he wrote on April 20, I886: “For my part, I lay little stress on the distinction, whether a man is an anarchist or a socialist, because it seems to me that too much weight is attributed to this difference. While the anarchists may have mad and brainless individualists in their ranks, the socialists have an abundance of cowards. For this reason I care as much for the one as the other. The majority in both camps are still in great need of education, and this will bring about a reconciliation in good time."

On May 17, 1886, he wrote: "I was of the opinion that the difference between socialists and anarchists should not be exaggerated, and when the bomb exploded and the staff of the 'Arbeiterzeitung' was imprisoned, I at once offered my services, which were accepted." $\mathrm{He}$ wished to be only collaborator, not editor, and said further: "Anarchism would not have disturbed me so very much, only Mostism, which makes a system of violent assaults and private vengeance, could never have been congenial to me. I do not believe that this or that row hurts the party as much as the oversensitive are trying to make out. On the contrary, a nation should also be taught to assert itself."

When Dietzgen went to Chicago, he had been asked by the National Executive Committee of the Socialist Labor Party to write articles on the situation in Chicago. But when he sent his report on the Haymarket riot, it was rejected, because "it was diametrically opposed to the views of the Committee." Dietzgen then made sharp attacks on the "Sozialist" and the National Executive Committee by various articles in the "Chicagoer Arbeiterzeitung:" and he wrote to a friend about this on June 9, 
I886: . . . "I call myself an anarchist in this quotation, and the passage left out explains what I mean by anarchism. I define it in a more congenial sense than is usually done. According to me,- and I am at one in this with all the better and best comrades, - we shall not arrive at the new society without serious troubles. I even think that we shall not get along without wild disturbances, without 'anarchy.' I believe that 'anarchy' will be the stage of transition. Dyed-in-the-wool anarchists pretend that anarchism is the final stage of society. To that extent they are rattle brains who think they are the most radical people. But we are the real radicals who work for the communist order above and beyond anarchism. The final aim is socialist order, not anarchist disorder. If the Chicago comrades would now avail themselves of the state of affairs in their city, I could help them considerably. The anarchists would then join our ranks and would form, together with the best socialists of all countries, a united and active troop, before which such weaklings as Stiebeling, Fabian, Vogt, Viereck, and others would be dispersed and forced to crawl under cover. For this reason, I think, the terms anarchist, socialist, communist, should be mixed together so that no muddle head could tell which is which. Language serves not only the purpose of distinguishing things, but also of uniting them, for it is dialectic. The words, and the intellect which gives meaning to language, cannot do anything else but give us a picture of things. Hence man may use them freely, so long as he accomplishes his purpose." . . .

The dispute was carried along for some time, and when finally his friend in the East rebuked him also, Dietzgen wrote on April 9, r888, a few days before his death: "I am still well satisfied with my approach to the anarchists 
and am convinced that I have accomplished some good by it."

Dietzgen was full of humor, always inclined to tease his friends and members of his family, and was in no way a Philistine. When some acquaintance reminded him of a promise, he replied: "Never take my word for anything, but consider it to be like mercury."

And to a female friend of the family, he wrote: "If the children or one of them should complain about my making more promises than I keep, I wish you would not think evil of me. It is the fault of the credulous shildren whom I have taught from their youth that they must not believe everything I promise, but they are incurable in this respect."

Another time he announces that he still has an income of two marks per day in Germany and continues: "I shall try next summer, and anticipate great pleasure from so doing, to live on this sum in some German village like some cavalier in reduced circumstances."

In a letter of July 18,1887 , he sounds a ribald note: “I have read Düntzer's 'Life of Goethe' of late. This noble poet was a great Don Juan! How well he could love and jilt! His many loves have inspired me with a strong desire to imitate him, only I fear that I should have more trouble in being faithless. On the whole, the man is an admirable character."

In November, 1887 , he announces that he has received money for some literary work and adds: "Now I am a rich man, and as soon as my engagement with the paper here has expired, I shall return to Germany and try the pleasure of a hermit life in my native village. That is my ideal. Then, if I could find some old sweetheart of my youth in that place, I challenge my century."

On February 2, 1888 , he wrote: “. . . There is 
still another thing which occupies me a great deal and which I can mention to you only quite confidentially. I am engaged in deepening an old friendship of my youth into love. If I knew that you were in a better mood to listen, I should tell you a little more about the foolishness of the aged; but now I shall wait for a better time

While Dietzgen accomplished remarkable work in philosophy, and especially in dialectics, he was not less at home in political economy, in the study of the industrial development of society. With his sharp foresight, he soon recognized the trend of modern modes of capitalist production and their reaction on the political conditions of the various countries.

As early as $188 \mathrm{I}$, he wrote from Germany: "The United States will in my opinion remain the land of the future in bourgeois society. By means of the competition of the New World, the oppressive atmosphere of Europe will be cleared. Agriculture is visibly on the decline in Germany. The land is becoming more and more an appendage of the cities and is turned into hunting grounds, parks, and country homes. And if our nation does not rally soon and overthrow its exploiters, the whole of Europe will soon become a sporting place of Americans. Our working men emigrate to America, and the fatted bourgeois immigrate from over there. Then they will have their factories in America, and their residences in Europe."

And a few years later, in the first letter on logic written to his son, he declares that democratic and proletarian interests are identical and continues: "If this is not yet well recognized in the United States, it is due more to the fortunate natural resources of that country than to the scientific insight of its democracy. The spreading 
primeval forests and prairies offered innumerable homesteads to the poor and glossed the antagonism between capitalists and laborers, between capitalist and proletarian democracy. But you still lack the knowledge of proletarian economics which would enable you to recognize without a doubt that precisely on the republican ground of America, capitalism is making giant strides and revealing ever more clearly its twofold task of first enslaving the people for the purpose of freeing them in due time."

This is not the place to dwell on the main works of Dietzgen, "The Nature of Human Brain Work" and "The Positive Outcome of Philosophy." But it may be said that Monism, the science of the unity of all being, did not find a more eloquent, convinced and convincing champion than Joseph Dietzgen in the second half of the XIXth century. He handled his dialectics, the midwife of his philosophical productions, in a wonderfully refreshing and original manner. In that very interesting work "Feuerbach, The Roots of the Socialist Philosophy," Frederick Engels explains the nature of dialectics and says: "And this materialistic dialectics, which for years has been our best tool and our sharpest weapon, was discovered, not by us alone, but by a German workman, Joseph Dietzgen, in a remarkable manner and utterly independent of us and even of Hegel." — Here I leave the data furnished by Sorge.

Those who had become acquainted with my father's impressive and high-spirited style, were surprised at his mildness and modest reserve, when they made his personal acquaintance. But behind these qualities, there stood the just pride of his true convictions. We children had the utmost liberty in our intercourse with him, but when we tried to abuse this freedom or to be too smart, 
then he quickiy shamed us by a few words or by a meaning glance. A happier man than my father would have been hard to find, and none who was more loyal in all his relations.

Death was to him, as to Feuerbach, not an evil. But he dreaded long suffering and admitted that he was afraid of it, while he bore short attacks of illness with resignation and even with good humor. Death finally proved a friend to him, for it left him only a few seconds of time to feel the shortness of breath and consternation which I read in his face when he fell into my arms, breathing his last. Paralysis of the heart killed him within two minutes. It was on a pleasant Sunday, April 15, 1888. In the morning, after a walk in springclad Lincoln Park, we had emptied a bottle of wine between the two of us and had come home to dinner in the best of spirits. My father enjoyed his meal with his customary hearty appetite. When coffee was served immediately after dinner, one of my acquaintances happened to drop in. This was the cause of my father's lighting a cigar (instead of taking a half hour's nap as usual) and taking part in our conversation on the social question. My acquaintance had not even a superficial knowledge of the subject, which did not prevent him, however, from making offhand statements. In spite of my remonstrance against such ignorance, my father became more vivacious and excited than I had ever seen him. With a seriousness and emphasis which I shall never forget, he related that he had foreseen the modern labor-movement forty years before this date, and proceeded to explain his views on the imminent collapse of capitalist production, when suddenly he stopped in the middle of a sentence, with his hand uplifted, and died in the manner described above. He was not quite sixty years old. 
Simply and without any show, in harmony with the character of my father, we buried him by the side of the murdered anarchists in Forest Home Cemetery near Chicago, on April 17, 1888.

(Translated by Ernest Untermann.) 


\section{AN ILLUSTRATION OF THE PROLETARIAN METHOD OF RESEARCH AND CON- CEPTION OF THE WORLD.}

MAX STIRNER AND JOSEPH DIETZGEN.

BY EUGENE DIETZGEN.

LOCARno, March, 1905.

Stirner's work "The Individual and His Property" (Der Einzige und sein Eigentum), by its fundamental conception and frank advocacy of the principle of selfcentered individualism, reminds one of Macchiavelli's work, "The Book of Princes." Stirner is the most consistent modern champion of the individualist-anarchist, or bourgeois, manner of thought, which is represented in literature by such stars as Schopenhauer, Hartmann, Nietzsche, Hauptmann, Ibsen, Lombroso, D'Annunzio, Tolstoi, Maeterlinck, or men like Chamberlain and Brooks Adams. For this reason, we shall employ "The Individual and his Property" for the purpose of illustrating the proletarian monist method of research and world-conception, elaborated for the first time on the basis of a theory of understanding by Joseph Dietzgen, by comparing this theory with the dualist bourgeois conception of the mind and of the world.

Stirner is unique, stimulating, and brilliant in his negative criticism of the supernatural belief in the creative power of the absolute, or "pure," spirit. But he fails completely, and becomes himself sterile and be- 
witched, as soon as a positive criticism of his subject is demanded. On this field, he has long been outdone by the historical materialism of Marx and Engels and the theory of understanding of Dietzgen.

Stirner declared war against all spooks and their supporters, because christianity, liberalism, and utopian communism, instead of seeing through the hallucinations of the socalled pure spirit and its catchwords of god, liberty, morality, law, state, society, authority, etc., welcomed it and its creatures as allies for the degradation and enslavement of the individual. However, while Stirner flattered himself with having discovered an impregnable method of combat, he did not follow the example of Marx and Engels, who confronted the aprioristic hallucinations with the sober demonstration of the historical fact, that they were but necessary phenomena and companions of tendencies, which are conditioned on particular processes of social life and cannot, therefore, disappear until these do. Nor did it occur to him to forge a mighty weapon against obsolete conceptions after the manner of Dietzgen, who, inspired by historical materialism, deepened and elabo. rated it into a conception of the world by means of his analysis of the force of thought and understanding which revealed the dependence of the human mind on social conditions as well as its interrelation with nature and the universe. We shall show in the following lines, that Dietzgen's theory of understanding was the first to thus completely demonstrate the fantastic nature of all purely deductive abstractions and of the "pure" spirit. Stirner does not do anything of the kind, but contents himself with pointing out the injuriousness of pure catchwords for the trusting individual, without suspecting the social and cosmic origin and basis of those catchwords. Consequently he necessarily remains in the same circle of mental 
hallucinations as his bourgeois opponents. And accordingly he recommends as a panacea - the same as all anarchists after him - that the consciously egoistic self, that is to say the individual with his psycho-physical power, who considers himself above society, be seated upon the world-throne as an individual and independent power, enjoying in his capacity of autocrat and hyperman only individual rights, without regard to society and nature and without any duties.

Stirner's ideas are not completely intelligible, unless one takes into consideration the most advanced intellectual tendencies preceding the March revolution, under whose influence he wrote his work. In this category belong especially the speculative communism of Babeuf, Proudhon, and Weitling, the first attempts of critical communism made by Marx and Engels in the "DeutschFranzoesischen Jahrbuecher" (German-French Annals), in March, 1844, which Stirner understood merely in an ideological way, furthermore Hegel's dialectic, and finally Feuerbach's realistic humanitarianism (The Essence of Christianity) and Bauer's idealistic humanitarianism (in the "Allgemeine Literaturzeitung").

In this storm and stress period, Stirner deserves mention as one of the most brilliant minds of liberal intellectualism, excelling by his quaint natural wit and his artistic imagination.

In his vain struggle with the ideological method of speculation and its spook of a pure spirit, he has many a flash of bright thought, which strikes one like that of some modern thinker, making a passionate appeal to one's selfreliance and independent thought, selfdependence and selfemancipation, as opposed to the servile degradation of one's personality by religious, philosophical, liberal, and social spooks. It is this spirited appeal to selfrespect, 
which constitutes the important merit of Stirner's work, for by means of it he creates at least strong doubts as to the authority of any and all spooks, which are the creations of the aprioristic conceptions of the clerically divine, liberally moral, and socially humanitarian ideologies.

Stirner also takes occasion to say words full of warmth and strength about the proletariat, without, however, realizing the definite historical role of this class and economic category of society.

The entire work of Stirner is pervaded as much by his strong side, the negative ridicule of the catchwords of speculative idealism, as by his weak side, the fantastic and idealistic deification of pure egoism.

The reader will look in vain for some positive point of vantage in this hymn of egoism. It has neither bottom nor boundaries. Stirner is not content to use egoism as an indispensable and sound weapon against the hypocritical, sentimental, and servile selfdenial, which is being preached by the priesthood of all creeds. Instead, he has such an exaggerated and fantastic conception of egoism, that it loses all definite outlines and becomes quite as much of a spook as the clerical and liberal liberty, law, humanity, authority, etc.

With equal lack of insight into the natural differentiation and at the same time natural unity of all things and phenomena christianity worships the spirit of god, liberalism the spirit of the individual, Hegel the absolute ideal, Feuerbach human love. And so Stirner worships self-love. In his egoism, the immediate, more remote, and most remote personal interests all merge without distinction into one, so that love, selfsacrifice, selfdenial, and even selfdestruction have an indiscriminate place in it.

It is this peculiar antidialectic conception of abstract 
ideas, which gives to Stirner such a confused notion of egoism, and of the importance and power of the individual separated from society, and by this means he places his followers, the anarchists of every shade and the supermen of the Nietzsche stamp, on strained terms with all sober logic.

Experience teaches, that a man becomes possessed as soon as he falls so completely into thraldom to catchwords, that he only believes in them and makes no conscious effort to analyze them and bring them into accord with the array of facts which can be tested empirically. With naive faith, superstition and fantasy simultaneously begin their confusing play. Then the intellectuals among the liberal and confessional preachers know how to inaugurate their partly brilliant, partly artistic, scintillation of words, which enables the shrewdest of them to hoodwink the gullible. It is a perplexing music which the leading preachers make for their faithful lambs in order to fish in troubled waters, either consciously or unconsciously. Among others, apart from Stirner, it is by the way, especially Nietzsche, who is such an unconscious fisherman, and who even excels his master in his confusion of abstract ideas. In spite of the perfect form of such works as "Thus Spake Zarathustra," it will be hard to find any reader, who would be able to cull from this tinkling of words a single clear and new thought, which would stand the test of scientific analysis.

Because morality, order, law, the state, etc., have so long been employed as bogies, therefore Stirner opines that this whole plunder should be thrown away.

$\mathrm{He}$ derives the right of sterile negation from his extravagant lack of discernment. But for this very reason, Stirner cannot detach himself from faith and arrive at science. For him, in true bourgeois fashion, 
the dependent nature of the individual on the universe and society has remained as much of a riddle as the equally dependent nature of those abstract ideas. And thus he struggles helplessly in his own snares. Because the individual is abused by those catchwords, which neither the liberals nor himself could digest, therefore they have no right to existence at all in the opinion of Stirner and are supposed to fall at the mere commano of his self, his individuality. And such a harebrained mentality is taken seriously by the anarchists, by Nietzsche, and his disciples!

The work of Stirner naturally ends in making a saint of the pure ego. This is the insane idea of the "Indi. vidual " and his unenviable "Property," as we shall now try to demonstrate more clearly.

We certainly agree with Stirner in opposing the priestly and illadvised use of catchwords, but we do not spill the child with the bathing water. If Stirner had not himself remained entrapped in priestly conceptions, he would have made short work of the absolute sacredness of those great catchwords, by analyzing them and demonstrating that they were relatively sacred, that is to say wholesome, according to time and place.

It is no wonder, that the fundamentally utopian statements of Babeuf, Proudhon, and Weitling did not lead the most typical apostle of anarchism into a new road. The same is also true of the romantic articles of Bruno Bauer. But at least Hegel's dialectics and Feuerbach's theses should have stimulated Stirner to more fertile thoughts than a mere negative critique, granted that such a critique on his part was in some respects justified, if he had only possessed a little more aptitude for historical interdependence and the theory of understanding.

For want of study of the laws of thought and society, 
Stirner's struggles for a positive conception of the world did not yield any clear result concerning the relation of the individual toward society and nature. This is the final reason that prevents him from culling the sound kernel from the catchwords which he criticizes. It is therefore but a consistent act of helpless desperation and a bowing to the undefeated spooks, that he always hides behind the armor of a knight of pure egoism.

$\mathrm{He}$ sees, indeed, the interaction of mind and body and that of these two in society and nature, so that their mutual interdependence is revealed. But he does not arrive at a clear understanding of the degree and importance of the dependent role of the individual factors in this interrelation, because the actual mutuality and opposition of phenomena obscures for him their equally real social and cosmic unity. But it is this total interrelation of all phenomena, which compels man to distinguish the individual relations, according to their importance, by genera, species, classes, families, etc., in order to orient himself in the universe. Stirner lacks appreciation for the dialectics and interrelation of things and thoughts. Hence the understanding does not come to him, that the human individual, being a product of nature in body and soul, is so inseparably and universally connected with nature, that his growing individuality and power is conditioned on the increasing understanding and utilization of this natural, and socially ever-increasing, dependence. $\mathrm{He}$ ignores furthermore the fact, that such an understanding and utilization is not due to the individual personality as such, but to its capacity as a member of society and nature, because the individual can exist only in this capacity, and develop, gain power and exercise it by this means. And finally he remains ignorant of the fact, that a society and its egos are mainly determined, so 
far as the historical peculiarity of their existence is concerned, by the particular degree of development of the social forces of production of their time. This understanding came to Engels by a study of the English, to Marx by that of the French revolution, and it came to both of them at the time of Stirner. While Feuerbach had demonstrated, that men and human existence were not created by god (spirit, consciousness), but that man had created god after his own image, Marx, having studied also social science, taught furthermore: "It is not the consciousness of men that determines their existence, but their social existence which determines their consciousness."

Mehring has shown in volume II of the "Posthumous Writings of Marx, Engels, and Lassalle," that Marx had found the enlightening sentences almost literally in the works of the oldest French socialists: "If man is formed by external circumstances, then circumstances must be modeled to suit man. If man is by nature social, then he can develop his true nature only in society, and the power of his nature must not be judged by the power of the single individual, but by that of his social surroundings." In the further development of this thought, Marx wrote in the "German-French Annals": "Not until the real, individual man discards the abstract citizen of the state and realizes that he, as an individual, in his actual life, his individual work, his individual relations, is a generic being, not until man has organized his individual powers into social powers and ceased to separate his social powers from his political powers, will human emancipation be accomplished." (See Mehring, "Posthumous Writings, etc.," volume I, page 352, German edition.)

The Marxian term "generic being," which is plainly defined at this place as an individual conscious of his social 
power, is ridiculed by Stirner as an empty abstraction, because he did not know what to do with it from mere ideological narrowmindedness. Stirner also passed without understanding by the other attempts at critical communism, which Engels published in the same periodical in his "Outlines For A Critique Of Political Economy."

"I have built my affairs on nothing (but myself)." With this pert statement, Stirner begins and concludes his book.

It is not nature, the creator of the human individual, nor society, the supporter of his life, which are the determining powers, according to Stirner, but the single individual, who acknowledges them only so far as they serve him. But if they refuse to do him this favor, the individual places himself above nature and society and becomes - a superman. "Why do you hesitate to take courage and constitute yourselves into the center and main factor of things? Why do you pine for liberty as you do for your dreams? Are you your own dream? Do not stop to inquire of your dreams, your imaginations, your thoughts, for all that is but a 'hollow theory.' Inquire of yourselves and care for yourselves - that is practical, and you love to be 'practical' - Therefore turn rather to yourselves and be your own gods or idols. Bring forth that which is in you, show it in the light, reveal your own selves." Thus speaks Stirner.

And how does he propose to realize this? Very simple! "I secure for myself liberty against the world to the extent that I make the world my own, that I conquer and take possession of it, be this done by any force whatever, by persuasion, request, a categorical demand, or even hypocrisy, fraud, etc.: for the means which I use for this purpose depend on what I am." And again, "My freedom does not become perfect, until it is my power; and 
by this means I cease being merely a free man and I become a selfpossessed free man. Why is the freedom of nations an 'empty word'? Because the nations have no power. With one breath of the living ego I blow down whole nations, whether it be the breath of a Nero, a Chinese emperor, or a poor writer."

These words remind one of "Uncle Braesig," who thought he had explained poverty, when he called it "pauvreté." Without power no liberty; but how do I get power? All that Stirner has to say in reply is that power dwells in myself, in the individual, who becomes a selfpossessed free man, when he brings forth power out of himself. The "free" will of the individual is supposed to suffice for this purpose! Leaving aside the fact that Stirner himself has nothing but words to show in substantiation of his claim- - for we learn from his biographer that he ended in poverty and misery in spite of his mighty Ego - where are there in authenticated history any individuals endowed with such mighty wills and power by their own unaided personality? The superhumanly powerful role ascribed by historical fables to chiefs of savage hords, those " selfpossessed free men " by virtue of their physical strength and ability, has been reduced to its modest and dependent measure, and no one has accomplished this more thoroughly than Lewis $\mathrm{H}$. Morgan in his "Ancient Society." We need not, therefore, pause for any further consideration of the exaggerated power of such "strong men." The "selfpossessed" power of the individuality is merely that spleen, of which Stirner cannot rid himself. This is his misfortune and that of all liberals, who have this in common with the anarchists and the autocrats, in short with the entire bourgeoisie, that they believe, in perfect harmony with their system of "free" competition, in the 
spook of the selfpossessed free individual. It is the merit of Marx, Engels, and Dietzgen, to have demonstrated, that the fundamental explanation for this dogma, which deserves a place by the side of the infallibility of the pope, is found in definite conditions of production and existence giving rise to the dualistic method of thought of a bourgeoisie operating with absolute contradictions.

Marx and Engels have shown more clearly than their predecessors the role of the individual as a social power, while Dietzgen fortified and extended this proof, which is of such great consequence for the study of society and history, by showing in his theory of understanding that the human faculty of thought is no more and no less than an ordinary cosmic force and phenomenon, and that it is in its activity absolutely dependent upon the connection with other natural phenomena. In this way Dietzgen cleared the road for a scientific conception of the world. On the other hand, whether we believe with the worshippers of a god in a supernatural being, or with the liberals in a supernatural human spirit and will, we believe in the same dualism and agree in the last analysis with the anarchist confusion concerning the position of the personality in society and nature.

Religious dualism: God and nature; liberal dualism: intangible spirit and tangible matter; anarchist dualism: individual and society - nature.

The dualistic relationship between the believers in a god, free thinkers, and anarchists is palpable. For the believers in a god, the rule of the individual over mankind is a divine dogma; for the liberals, it is a spiritual dogma; and for the anarchists, it is a demand of the "free" personality. For all three of them, this dualism obstructs their grasp of the monistic interrelation of in. 
dividuals, society, and nature, thus preventing their radical rupture with all spooks.

Stirner ridicules the universal abstract liberty, but clings to an equally abstract power of the "self-possessed " individual. However, he does not take the least trouble trying to expose this power and its anything but individual origin.

In opposition to him, Engels, standing on the shoulders of Hegel, drew the veil from the verbose individuality and will-power of Stirner with the following words, to be found in his "Anti-Dühring": "Hegel was the first to correctly represent the relation of freedom and necessity. For him, freedom consisted in the understanding of necessity. Necessity is "blind" only to the extent that it is not understood. Freedom is not found in the fancied independence from laws of nature, but in the understanding of these laws and the resulting possibility to make them produce definite effects according to our plans. This applies equally to the laws of nature outside of society and to those which regulate the physical and intellectual well-being of man inside of it, for these two classes of laws, while they may be separated in thought, cannot be held apart in reality. Freedom of will means, therefore, simply the faculty of making decisions based on understanding. The more a man's judgment concerning a certain question is free, the greater will be the necessity by which the substance of this judgment is determined. On the other hand, ignorance engenders a vaccillation, which chooses between various opposing possibilities with apparent arbitrariness, but proves by this very fact its lack of freedom, its subjection to the very thing, which it ought to dominate. Freedom therefore consists of our control over ourselves and nature based on an understanding of natural necessities. Hence 
it is as a matter of course a product of historical development."

We observe, then, that Engels understands the art of combining freedom and necessity dialectically, by declaring that freedom results as a historical product from a study of necessity and its social and natural interrelations, in such a way that any one may make the test himself and thus arrive at a scientific understanding. In the same way, Marx shows that the power of the individual is from natural necessity a social power, and that the past great struggles of mankind were fundamentally social and class struggles. We thereby secured practical illustrations of the fertility of the critical and inductive method taking its departure consciously from facts and classifying them into laws, or rules. Both Marx and Engels were enabled by this method to secure quite as exact results on the field of historical, economic and political science, as natural science, strictly speaking, in its own field. On the other hand, the purely deductive method, resting on the irreconciled antagonism of a supernatural mind and natural matter, which made it dualistic, has demonstrated its scientific impotence, because it pretended to derive understanding in an $a$ priori fashion, that is, independently of an analysis of the general laws of experienced facts, by means of "pure" spirit. So far as the past is concerned, we are obliged to recognize that the fantasies generated by the purely deductive method had a certain merit, because they were a necessary social product of their time, which made further progress possible. But in our day, these fanciful imaginations have become injurious and reactionary on account of changed social conditions, and even Stirner's example proves this.

The substantiation of the critical and inductive method 
by means of the analysis and synthesis of understanding and nature, and the demonstration of its fertile and consistently monistic applicability to all social and cosmic phenomena, was the particular work of Joseph Dietzgen. It accompanied the rise of the proletariat, which assisted Marx and Engels in realizing the nature of social movements and interrelations. Their studies enabled Dietzgen to make another step forward by founding the monistic conception of the world on his theory of understanding.

Seeing that the consistently dialectic and monistic, or critically inductive, method of thought with its cosmic crowning was a necessary concomitant of the rise of the proletariat as a social-economic class and had for its premise the existence of such a class, we are justified in calling it the proletarian method. This term is furthermore fitting for the reason that all other social classes, owing to their economic interests, are necessarily advocates of the dualistic, or purely deductive method of thought, in all fields of abstraction, such as those of the state, society, morality, freedom, etc. If we comprise all ruling classes on account of the identity of their interests as opposed to those of the proletariat as one bourgeois class, then we find that this economic antagonism expresses itself also as an antagonism of the bourgeois and proletarian method of thought. On one side we have the bourgeois, dualistic, or purely deductive method, on the other the proletarian, dialectically monistic, or critically inductive method. This applies even to the most advanced bourgeois natural scientists in every case, where they pass from their specialties to the fields of the socalled science of the intellect.

How is it, now, that a proletarian arrives more easily at a consistently monistic method of thought, and at a clearer understanding of social and cosmic interrelations? 
Is it, perhaps, because proletarians are individuals of deeper insight and better than men of other classes? By no means. So far as personality is concerned, a proletarian is equipped no better than a bourgeois. That which distinguishes him to his advantage from a bourgeois is not due to him as an individual, but as a member of a definite economic class. Being a member of the wage-working class, of the proletariat, he is left by virtue of his economic condition with no other inalienable property but his intellectual and physical labor-power. This state of things carries with it the growing understanding of the fact that his might and power are not due to his own unaided individuality, but to his connection with the labor-power of his class. The proletarian is thus taught by his economic condition, that he must use his power as a social one. By this means he becomes classconscious, conscious of the importance and power of his class in society. It is not difficult to understand, that the socialist aim of the socialization of the means of production must necessarily follow from this class-consciousness. The bourgeois, on the contrary, being an advocate of the private ownership of the means of production, favors the opposite individualistic representation of his interests. If a bourgeois unites with the members of his class, he does so merely under the pressure of competition or of the proletarian organization, but always with the reservation of Stirner to the effect that the "freedom" of his organization shall permit him at any moment to sell his shares and leave his club as soon as it interferes with his individualist principles. $\mathrm{He}$ is enabled, by virtue of the above-named property, to avail himself of the "freedom" of his association, of course at the expense of others. Not so the proletarian. His economic condition necessarily prescribes to him a permanent 
association with equals, who shall use the means of production co-operatively for their common interest, in order to secure for each member the greatest possible happiness in the freest development of his or her physical and intellectual faculties. Owing to the fact, that no society, not even one without privileges, can exist without definite regulations, and that among equals two are more powerful than one, the majority determines the rules of common work and life for all. This is resented by the individualism of the liberals and anarchists, because they want to be more than equals, that is to say, supermen. Unfortunately for them, necessity enforces its decrees against all pious wishes. And this necessity consists of the fatal law compelling everybody's dependence on socially useful labor, without which even the greatest genius cannot live. The liberal-anarchist dream of the individual and his absolute property, free from the bonds of society, could not be realized, even if nature were to grant freely and lavishly the most excessive demands for food, clothing and shelter. For even in that case, we should still be bound to respect definite laws regulating the association of men in such a way that the development and care of all would be promoted, including minors and sick, children and aged.

In order to be able to use the proletarian, consistently monistic, conception and its critically inductive method with assurance, we must first become aware of the perversity of the liberal-anarchist, self-centered, dualist mode of thought, and overcome its allegedly aprioristic and deductive method.

An isolated man in his natural state is helpless against the forces of nature, which include other men and wild animals. He must rely for protection and sustenance on the assistance of his fellowmen. Therefore he associates 
with them from necessity. But the overpowering forces of nature, such as fire, wind, water, disease, inspire him with fear, because he does not understand and know how to control them. He feels that they threaten his existence. Therefore he tries to meet these mysterious forces by equally mysterious measures. The first result of the feeling of helpless dependence on nature was the rise of religious cults. These cults remained natural religions, so long as man had not learned to understand the natural character of elementary forces and to make them tributary to himself. Later on, the dual nature of individual power, which is at the same time individual and socially cosmic, tormented man with religious pains. Natural religion then became spiritual religion, transforming the idolization of nature and of the present world into an idolization of the spirit and the next world. History teaches us in accord with the theory of understanding, that this transformation took place in the course of thousands of years as a corollary of the transition from communist property in means of production to private property. So long as men lived in primitive communities and applied their individual powers directly as social ones, natural religion prevailed. Exchange of products with neighboring communes, in other words, the removal of products outside of the producing commune, did not arise, until the individual communes had raised their productive power to the point where they could produce more than they needed for their own consumption. For a time, the commune remained the owner of the articles of exchange in the interest of its members. But no sooner did the products find a market outside of the commune, than the wedge of dissolution was driven into primitive communism. As a rule those individuals, who had the function of placating the idols, or who had some 
other prominent social position, succeeded by means of their authority in managing the exchange of products for their own benefit and transforming themselves from servants into masters of the commune, by securing control of the means of production. The institution of such private ownership was naturally the end of communism. The way was cleared for the development of the production of commodities, leading toward modern capitalism. The assumption of superiority on the part of an individual over society, as a permanent feature, was made possible only by private ownership, which on its part owed its rise to a definite point of development of the productive forces of the commune. Thanks to private property, the power of the individual seemed to be due less to social labor and to the further interrelation with nature, than to his own individuality. The articles of exchange of such independent individuals necessarily assumed the character of commodities, owing to the lowly developed state of the productive forces. By this means, the plain social nature of individual labor in the commune assumed the mysterious character of products of individual labor, of commodities. Individualism triumphed over communism. The gods of nature of consciously social men gave way to the supernatural gods of individuals misapprehending their own social and cosmic interrelations. Individual property led to the condensation of polytheism into monotheism. Finally the "pure" spirit of the individual became the god of "enlightened" capitalism. Just as the virgin Mary of the catholics gave birth to Christ without having become pregnant, so pure reason begets thought without being impregnated by the objects of sense perception. Thus results the unconditional and aprioristic " science," which is still being taught quite generally by the modern universities. The 
characteristic mark of this science is that it takes its departure from the principle of pure spirit. Hence it remains theological and theosophical. We propose to confront it later with proletarian science, which takes its departure consciously from verifiable and matter of fact premises.

The indissoluble interrelation of the individual with society rests, according to us, on his helplessness, if left with no other resource for his maintenance and defense but his own labor-power. Man is, therefore, compelled to seek the assistance of other men. This dependence explains the inevitable social nature of individual laborpower. Marx calls the understanding of this nature of individual labor-power the essential point which is required for an intelligent discussion of political economy. It is the great merit of Marx and Engels to have substantiated and propagated this knowledge. This is the basis of the analyses in Marx's "Capital ", this reveals the dual nature of private property, this furnishes the key for an understanding of the nature of commodities, value, money, capital, and of the entire social science. It also lays bare the kernel of such terms as morality, right, state, authority, etc.

It was the misfortune of Stirner to regard these terms as arbitrary catchwords, while the Marxian Dietzgen knows how to show up the sober social nature of these spooks. With regard to morality, he says in his "Nature of Human Brain Work": "Morality is the aggregate of the most contradictory ethical laws which serve the common purpose of regulating the conduct of man toward himself and others in such a way that the futrre is considered as well as the present, the one as well as the other, the individual as well as the genus. The individual man finds himself lacking, inade- 
quate, limited, in many ways. He requires for his complement other people, society, and must, therefore, live and let live. The mutual concessions which arise out of these relative needs are called morality."

"The inadequacy of the single individual, the need of association, is the basis and cause of man's consideration for his neighbors, of morality. Now, since the one who feels this need, man, is necessarily an individual, it follows that his need must likewise be individual and more or less intensive. And since my neighbors are necessarily different from me, it requires different considerations to meet their needs. Concrete man needs a concrete morality. Just as abstract and meaningless as the concept of mankind in general is that of absolute morality, and the ethical laws derived from this vague idea are quite as unpractical and unsuccessful. Man is a living personality, whose welfare and purpose is embodied within himself, who has between himself and the world nothing but his needs as a mediator, who owes no allegiance to any law whatever from the moment that it contravenes his needs. The moral duty of an individual never exceeds his interests. The only thing which exceeds those interests is the material power of the generality over the individuality."

"If we regard it as the function of reason to ascertain that which is morally right, a uniform scientific result may be produced, if we agree at the outset on the persons, conditions, or limits within which the universal moral right is to be determined; in other words, we may accomplish something practical, if we drop the idea of absolute right and search for definite rights applicable to well-defined purposes by clearly marking the boundaries of our problem. The contradiction in the various standards of morality, and the many opposing solutions 
of this contradiction, are due to a misunderstanding of the problem. To look for right without a given quantity of sense perceptions, without some definite working material, is an act of speculative reason, which pretends to explore nature without the use of senses. The attempt to arrive at a positive determination of morality by pure perception and pure reason is a manifestation of the philosophical faith in understanding a priori."

And with regard to right, Dietzgen writes in the same work: "Reason cannot discover within itself any positive rights or absolutely moral codes any more than any other speculative truth. It cannot estimate how essential or unessential a thing is, or classify the quantity of its concrete and general characters, until it has some perceptible material to work upon. The understanding of the right, or of the moral, like all understanding, strives to single out the general characteristics of its object. But the general is only possible within certain definite limits, it exists only as the general qualities of some concrete and perceptible object. And if any one tries to represent some maxim, some law, some right, in the light of an absolute maxim, law, or right, he forgets this necessary limitation. Absolute right is merely a meaningless concept, and it does not assume even a vague meaning, until it is understood to stand for the right of mankind in general. But morality, or the determination of that which is right, has a practical purpose. Yet, if we accept the general and unconditional right of mankind as a moral right, we necessarily miss our practical aim. An act, or a line of action, which is universally or everywhere right, requires no law for its enforcement, for it will recommend itself. It is only the determined and limited law, adapted to certain persons, classes, nations, times, or circumstances, which has any practical value, and it is 
so much more practical, the more defined, exact, precise and the less general it is."

What signifies, furthermore, the state which Stirner denies offhand and which individuals are supposed to be able to blow over by sheer will-power? It is well known to be nothing else but the executive committee of the ruling minority, who can impose their rule, thanks to the private ownership in means required for the production of the material necessities of life, so long as this rule and this private ownership are necessary for the development of the productive forces to a climax where the development of personality becomes possible for all. With the advent of this climax, and after the victorious struggle of the proletariat, driven forward by its material requirements, minority rule, or the state, disappears and gives way to universal suffrage and rule. Where all rule, nobody serves, and vice versa, where all serve, nobody rules. We refer the reader, who would inform himself or herself further about this point, to Kautsky's “ Erfurt Program " or to Marx's "Capital." These works will throw a bright light on some more catchwords of Stirner.

The elaboration and demonstration of the following axioms: The human individual is a social laborer, and: Human labor is a social organism, which determines the nature of the interior world of the individual member, that is, his consciousness and mental activity in all lines of thought such as religion, ethics, law, politics, science and art, by producing changes in the economic nature of the society and the world surrounding him,- are the fundament of Marxism in a strict sense. They furnish the key for an understanding of critical communism as a science of society and a conception of history.

Social labor produces the requirements for the existence of individuals. The organization of the productive 
process is determined by the available forces of production, that is to say, by the means and methods of production. The degree of development of these determines the character of a society and its members. It explains the introduction of private property, slavery, feudalism, and capitalism. It justifies on the ground of historical necessity the rule of minorities as well as the abolition of class-rule by the proletariat. We are indebted for this knowledge to Marxism in the strict sense.

However, this scientific theory, known as Historical Materialism, which is substantiated by a critical investigation of any period where sufficient economic facts were so far available and looked into, does not satisfactorily reply to the question, why mental activity is to such a determinating degree influenced by economics. Is our mind not free to think as it pleases? Such, at least, is the belief of most people and even of many socialists who, therefore, consider Marxism rather as one-sided and dogmatic.

Thanks to the epistemological researches of Joseph Dietzgen, Marxism was here again confirmed and, besides, expanded. It now culminates in these additional proofs: The force of thought operates only by means of an inseparable interrelation with material furnished by sense perceptions. This material exists not only in thought, but also in an objective and perceptible form as a part of the cosmos, that universal organism which is the premise of all others. Hence all phenomena, including the force of thought and the human individual endowed with it, are organic members of the cosmos, and this natural, infinite, and organic interrelation is the long-sought final and unitary explanation for all phenomena. By substantiating these theses with his critique of understanding, Dietzgen has furnished the reply to the ques- 
tion, why it is that within the universal interrelation economics has a predominating influence over mental activity. In this way Dietzgen deepened and perfected the Marxian conception of social evolution and elaborated it into a scientific conception of the world. Herein lies the significance of Dietzgen's life's work.

Dietzgen left no bulky volumes behind him. He was not a professional writer, and the struggle for existence granted him no leisure, save for occasional writings. So much the more valuable is the little that he wrote. The fact that his importance for Marxism has not been duly recognized so far is partly attributable to Dietzgen's great bashfulness and reserve, and to his excessive confidence in the perspicacity of his readers. Thus, in all his works, more particularly in his "Excursions of a Socialist into the Domain of the Theory of Understanding " and in "The Outcome of Philosophy," he gives any reader not familiar with the positive work of classic philosophers the impression that he is discussing them rather than presenting his own researches. Nevertheless, the soberly scientific and cosmic theory of thought and conception of the universe presented in these works of his are the original achievement of Dietzgen, for which his predecessors have naturally built the steps, without, however, climbing to the height of this thinker. In order that Dietzgen's cosmic and monistic dialectics and its particular method of thought and enlightment may be used in the service of the proletariat more than heretofore, it seems to us appropriate to emphasize at this point, that they are a valuable perfection, supplement, and therefore development, of Marxism. This is not the place for a complete demonstration of our claim. Here we simply desire to make use of the outlines of Dietzgen's consistent monism for an explanation of such terms as re- 
ligion, conscience, infinity, and conception of the world, for which Stirner and the bourgeoisie vainly sought a clear and scientific understanding.

Whoever wishes to get a clear understanding of the world and its phenomena, must first grasp the relation of the human individual to nature. To this end, again, it is indispensable that we should have a clear perception of the force, by means of which we seek understanding. This is the force of understanding and thought, the human mind.

An analysis of this force shows, that we cannot think without any material furnished either in the present or the past by sense-perceptions. Thinking signifies, therefore, to operate the force of thought by means of material furnished by present sense-perceptions or by means of material of past sense-perceptions stored away in memory. This material is an indispensable premise of thought.

This fact may be substantiated by every one who will test himself and see whether he or she can formulate any thought, which did not originally arise in some way out of the contact of the mind with some material perception. If any one should present to us any term, which we cannot trace to some perceptible fact, then we cannot get any meaning out of it aside from the fact that we hear or read the mere word and later on repeat it in a similar connection without regard to other sense-perception and without formulating any clear idea, until we have experienced the perceptible mate of the mere term in some form. Our thought becomes so much clearer and more scientific, the more consciously it takes its departure from the critique of experienced facts, and vice versa it becomes so much more confused, the less we stick to experience and yield to imagination, that is to say, the more rein we give 
to inexperienced and therefore inexact reasoning without any conscious touch of reality. For this reason thoughts which are suggested to children, such as morality, liberty, justice, god, and devil, have such powerful influence over their minds, the same as fairy tales, because children are especially apt to assimilate ideas without criticism, on account of their untrained faculty of thought and their limited experience. What is true in this respect of children, applies also to nations in their childhood - fantastic thought appeals to them more strongly than a scientific reference to verifiable facts.

Though Neo-Kantians and garret-philosophers claim that the world is merely a matter of consciousness, we know now that this is but a half-truth, for the world of phenomena exists not only in our consciousness, but also outside of it in perceptible reality, otherwise it would not exist for us at all. Consciousness does not register anything that has not been supplied by sense-perceptions. Indeed, the universal being, or the universe, consisting of intellectually and sensually perceivable phenomena, is the primary fact. It is not, in the last analysis, a product of man, but on the contrary, man is the product of the universe and to this extent the secondary fact.

We know this to be true as positively as we can know anything. In the first place, it is evident, that we human beings must first exist, before we can perceive any phenomenon. We cannot entertain the idea to attempt, without the premise of human existence, an analysis of the way in which the world of phenomena affects us, and to find out whether it exists merely in us as the content of our consciousness, or also outside of us as the thing which determines our consciousness in the last analysis. Otherwise we should not be trying to solve a problem, but suffer from insanity. The existence of man is, there- 
fore, the first premise of human thought and research.

How do we prove, then, that, aside from the existence of man, the other premise of the psycho-physical interrelation, or of the inseparable connection of mind and senses characteristic of all thought, is the existence of material furnished by sense perceptions? That this material does not exist merely in human consciousness, but also has its own objective existence and is even the primary fact which produces men and their consciousness as secondary phenomena?

We answer: Our proof is given in no other way than all proofs are, namely, by reference to facts which are universally verifiable by experience. Such facts would not exist, and there could be neither any possibility of understanding nor any science in that case, unless there were phenomena outside of us which exist independently of individual man, although they can not exist for mankind independently of human consciousness. It is due only to this obvious fact that one man can convince another of the reality of some objective phenomenon and of its existence independently of himself, by making another perceive and experience the same phenomenon through his senses and intellect. We know and prove furthermore, that this same phenomenon still remains and continues to exist outside of our mind, even if we, as concrete individuals, do not remember and perceive it any more with our senses.

Owing to the fact that man has the intellectual faculty of dispensing later on with the objective form of some phenomenon previously experienced at a certain time and place, and of studying its relations, especially as regards its origin and end, without further actual contact with it, and seeing that individual phenomena are relative and perishable as compared to the absolute universe, philoso- 
phers have hitherto attempted to disregard also the premise of this universe and to penetrate with their studies even beyond it. When they did not succeed in this, they did not overcome their traditional theological bias in order to arrive at the plain understanding that the absolute universe is the fundamental premise of their individual existence and their force of thought as well as the premise of the concrete existence and life of every individual phenomenon. On the contrary, their failure induced them to return to the mere faith in the supernatural existence of a god and finally to the faith in a supernatural pure spirit. Particularly since the time of Descartes (Cartesius) the pure spirit was elevated to the position of the only and actual being, while all other beings, things or phenomena were reduced to products of thought. The senses then appeared in the role of nonessential tools of the spirit, transmitting nothing but imaginary realities which had no existence, save in thought. This is the theological or dualist conception, for since it contradicts the experienced mind and all verifiable facts, and is, therefore, opposed to all science, it necessarily had to seek refuge in a divine spirit, or transform the human mind into an object of supernatural faith. By this means absolute dualism, or the contradiction between thinking and being, was established. Dietzgen finally solved this unreconciled contradiction, by pointing out the universally verifiable fact, that every individual phenomenon, including man and his force of thought, is not of itself whatever it is, but exists only in and derives its particularity from the connection with all other phenomena of nature, so that this natural and universal interrelation, this universal being, is recognized as the absolute and uniform premise for every concrete phenomenon. Just as in a mathematical problem the 
solution is contained in the given magnitudes, without which the problem could not be solved at all, so the existence of the universal being, known as Cosmos, Universe or Nature, is the premise for the solution of every problem encountered by human beings. The possibility of understanding must be contained in the germ in human consciousness, for otherwise a more developed consciousness could never have arrived at it. Man cannot attempt to ask himself questions about the nature of consciousness, until this consciousness has developed. Not until man realized after many researches that he would have to make a special study of consciousness, did he perceive, that the process of thinking takes its departure from some given phenomenon furnished by sense-perceptions in such a way, that it exists objectively for us as well as for all others whose attention is called to it. And if man further analyzes a given phenomenon, he finds that, on the one hand, it does not enter into his thoughts in all its details without leaving anything unknown about it, but rather retains its separate existence and can be further perceived by us and others, and, on the other hand, that every individual phenomenon does not exist in itself alone, but is always a link in that chain of existence which we call the universe. It is this chain of existence against which the individualist-anarchist bourgeois philosophers, whose starting point is the free will and independent mind, are rebelling. They do not like to abandon their self-centered aprioristic sailing of the clouds, nor trace their steps down to the universal being. In such fashion they come by their supernatural aim, the faith in some spook by which their own imagination deceives them. We, on the other hand, can lead them easily ad absurdum, for we have but to remember that thinking is the consciousness of being, an inseparable 
connection with some object outside of thought, the ex istence of which may be verified by sense-perceptions. Both this phenomenon and our faculty of thought must be given, before we can think. But if we have recognized that the universal existence outside of our force of thought is the absolute premise for our thought, then it is simply inane to attempt to go with our mind beyond this universal being to where there are neither phenomena nor thought. In order not to become inane, we must, therefore, make our peace with the universal existence and rest content with it. We know, then, that this existence is the absolute truth; we no longer search for abstract truth in general, but rather for the relative truth of given phenomena by extracting the general unity from the manifold contradictions, by separating the rule from the exceptions. And these scientific truths we find exclusively by a conscious reference to such verifiable parts of the universe as become the object of our study. We leave pure speculation and faith to the philosophers and theologians, and prefer to study and work by means of mind and senses. The theological conscience is seen to be nothing else but a vague and unconscious memory of conceptions that were originally gained in a psychophysical manner. Therefore it belongs in the same class with faith and fantasy, and is called conscience as distinguished from science.

The fact that the human mind is compelled to connect itself with definite parts of the universe and take its departure from them in the quest after the general, the truth, the rule, or the law, implies that we construct the concept of a universe ourselves, recognizing that it consists of parts which are organically arranged in time and space as well side by side as one following the other, limiting and supplementing one another. We understand, 
then, that the universe is the all-combining and all-embracing organic being, and that the mind, or consciousness, is one of its parts endowed with the peculiar power of serving as an instrument of orientation in the general interrelation. The universal existence is therefore recognized as the fundamental and absolute premise of our mind, and of all other phenomena, substances, or forces. We can affirm this in such a positive manner, because we found by the above test of the force of understanding that it can operate only by means of given natural origins and facts, and that these origins and facts are members, together with the subjective mind, of the infinite interrelations of nature, as any one may ascertain for himself.

Now we are at last done with speculations about absolute truth. For we have found it to be the absolute universe, the aggregate relations of all phenomena perceptible to psycho-physical man. Whatever does not partake of the psycho-physical nature of the universe, cannot exist for us. All spooks disband and stand revealed as products of fantasy, that is to say, as unconscious connections of the mind with objective senseperceptions, present or past, provided we test them by a conscious combination of the mind with the senses.

The absolute and sober truth of the universe is recognized as the absolute eternity, the infinite, all-embracing, and all-combining, the thing independent of space and time, the beginning and end of all phenomena. The universe has all the attributes of divinity without its dualism, without that faith which would believe in a supernatural mind and a supernatural world apart from the natural mind and the natural world.

Whoever looks about with open eyes, sees that every phenomenon of nature is connected organically with innumerable others. Every one of them has countless 
causes, but only one general cause, the universe. In the universe we possess at last the reliable, monistic, and, therefore, logical beginning and end of a consistent conception of the world, which harmonizes with all the results of science.

What, then, does our thinking, understanding, explaining, etc., accomplish? Evidently nothing else than that it explains the cosmic phenomena in their direct and indirect interrelations, classifies them and arranges them for our orientation and use. The mind operates always post factum, that is to say, after having been furnished with material by objective sense-perceptions. Even prophesying has any meaning only when it is a conclusion from definite premises. Thinking, understanding, explaining, realizing, are so many terms for a formal classification and description of the interrelations of given phenomena. We think and understand truly when we know how to distinguish the essential or general from the unessential or exceptional of any given object. And since objective reality is the final test, any one can verify whether he has been thinking truly, as soon as he compares his thought with the available material of the studied object. Whenever we can do this, we are independent of any and all authority.

We declare that the universe is an organism, because we find it to be a universal fact that every phenomenon is that which it is not of itself, but by grace of its interrelation with the universe. A phenomenon is so much better understood the more we know about its interrelations. These change continually in time and space, hence a phenomenon does likewise. On account of this eternal movement, we are compelled to detach any phenomenon, which we desire to study, from out the flow of interrela- 
tions, to fix it in time and space. By this means we ascertain its direct relations and secure, as it were, a flashlight-picture of it as a reference specimen for further studies. In this way we obtain terms for concepts and boundaries, or distinctions, in the infinite universe. It is the cosmic and organic interrelation of simultaneous and successive, eternally changing phenomena, which explains the operations of the force of thought, showing that this force does not only create distinctions, but is also a unifying force aside from its discriminating nature.

Being a part of the cosmos, the human mind is cosmic, partakes of the eternal and infinite nature of the cosmos, the same as every substance and force. This universal miraculousness is natural for the entire cosmos. However, as a cosmic member associated with other cosmic members, and compared to the cosmos as a whole, the mind is limited in space and time and perishable. Only the cosmos as a whole remains unalterable and stable in spite of the eternal transformation of its parts. The indestructibility of matter and the conservation of energy are explained by the constancy of the cosmos. This is a demand of reason due to critical experience.

The inductive critique of the force of thought leads us to a cosmic dialectics, to an organic interrelation and interpenetration of all phenomena. It teaches us to conceive of every phenomenon as an organic part of the cosmos, and to make this our point of departure and of return as the given absolute truth and the uniform basis. The cosmos does not assume the aspect of an aprioristic fantasy, because it is the all-embracing and sober reality verifiable by every and all experience. The concept of the cosmic organism, being consciously constructed out of this reality, furnishes us with a basis for a consistent monism. It leaves no room for any other but the one 
and natural cosmos, which is the arch-premise and impassable boundary of our mind. To attempt to go beyond this ultimate boundary of existence is as foolish as the idea of ascertaining the nature of consciousness without any existence. Only he, who attempts the one can attempt the other, in order to find in the fantasies of pure faith a fool's consolation. One who thinks like that is nearer to unconsciousness than to consciousness, and this is no compliment for his intellectual force.

"And then, above all other things, Give metaphysics due concern.

Then strive to grasp by deep reflection What is beyond the mind's conception."

These words characterize the essence of the purely deductive and unconditional "science." Or, to use another variation:

"I tell you this: A man who speculates

Is like a beast upon some arid heath,

Led in a circle by some evil sprite,

While round about is pasture fresh and green."

The human mind can form abstract concepts only by combining impressions derived from concrete objects and ascertaining in what respect they are generally identical. Hence we do not fully understand abstract concepts, until we have had practical intercourse with the concrete phenomena which are their premise. All concepts are more or less abstract and flexible. Because the parts of the universe, and our experiences relating to them, are in a process of continuous development, our concepts of them likewise remain fluid and flexible. The green pasture of the concrete phenomena turns into the arid heath of abstract concepts as soon as we forget the interrelation of 
the latter with the former. The fact that this interrelation has been overlooked in the first place, is due to the circumstance that man, overawed by the supreme power of nature and the wealth of its phenomena, and feeling his dependence upon them, mistook the way of fantasy and faith for the only one which would lead to the blessedness of an explanation of the world satisfactory to the mind and heart. The faculty of memory, which permitted him to retain and collect past impressions, forsook him when it would have been proper for him to recollect the objective and perceptible origin of all impressions, especially after such great abstracta as god, morality, liberty, immortality, etc., had been instilled in his mind without criticism for generations in the shape of dogmas or eternal truths. It was not until he had reached a high stage of development, when an understanding of social and natural interrelations had convinced him more and more of the passing nature and relative truth of all dogmas, that he restored consciously this psycho-physical connection on one field of research after another. Many sciences had far advanced before the theory of understanding became scientific. An epoch-making advance in this direction is due to Kant, who ascertained that experience, that is to say, the interrelation of mind with sense-perceptions, is the indispensable premise of all science. But Kant left to faith the task of replying to socalled final questions concerning the origin and end of the universe and man, because he did not acquire a clear understanding of the relation of man to the cosmos. Owing to historical conditions, he was still so enveloped by traditional faith, particularly the faith in eternal moral law, that he did not even attempt to employ the only scientific method, namely, that of consciously connecting the mind with sense-perceptions, for the study 
of metaphysical riddles. What Kant failed to accomplish was carried further by Dietzgen, thanks to the higher social stage on which he stood. Dietzgen's "The Nature of Human Brain Work" is devoted to the analysis of the scientific method of thought. In this little work he ascertains that the inductive or empirical method of thought is the one peculiar to the force of thought, that we cannot in reality think in any other way, but merely imagine we are doing so, because meditation is nothing else but associative elaboration, by means of memory, of the mental material obtained originally from objective sense-perceptions. But apart from many allusions, Dietzgen did not go very far beyond the standpoint of historical materialism in applying his method in this work, that is to say, he did not explicitly pass from the social to the cosmic interrelations. This is done, however, in his "Excursions" and in his "Outcome of Philosophy." Here he develops the dialectics of Marx and Engels, which is a theory of development through antagonisms to a higher stage, by perfecting it and pointing out that the universe is the last and highest organic unit, which combines monistically all other syntheses. By means of this understanding, the dialectics became a theory of the cosmic and organic interrelation and interpenetration of all phenomena. While in "The Nature of Human Brain Work" it was ascertained that phenomena exist outside and independently of individual man, in the "Excursions" and the "Outcome of Philosophy" the world of phenomena, the universe, or cosmos, were shown so to exist. Dialectics in its restricted sense found its culminating point in the cosmic interpretation. Antagonisms are henceforth recognized as merely relative, and the task of the mind is seen to consist in analyzing this relative nature. In the cosmic basis, we find the 
explanation of the fact that all antagonisms do not only exclude one another, but are also conditioned on one another. The point of view of an organic cosmos shows that all interrelations are parts of the absolute and come into opposition to each other as individual phenomena only because they mutually limit one another in time and space, being either contemporaneous or succeeding one another, in ceaseless flow. While Engels in his "AntiDühring " endeavors to show by many illustrations that the dialectic process is universal, not alone in society, but also in nature, Dietzgen reveals by means of his theory of understanding, by one stroke, as it were, that the dialectic movement is natural to all phenomena, seeing that they are all organic parts of the universe. All discoveries of natural and social science furnish daily further proofs for the correctness of this revelation by Dietzgen.

Now let us supplement Stirner's negative criticism of religion and world-conception positively by means of the positive critique of verifiable facts. The theory of understanding elaborated by Dietzgen is our pilot.

Religion arose from the feeling of human dependence on nature. Later this feeling was intensified by the equally inevitable feeling of infinity and the need for some unifying principle. Driven by his need to search for a final explanation of the world's phenomena, but as yet unable to see through the interrelations of society and nature, man misconstrued the natural final cause into a supernatural one. In this way, he created the metaphysical mode of thought, the absolute distinction between the natural and supernatural, which found its modern expression in the antagonism between physical matter and metaphysical spirit. This dualism is to blame for the habit of man to see only the differences, but not the interrelations and identities, in making distinctions. Man 
reasoned metaphysically, not dialectically. Stirner felt that the former method was wrong, but he did not succeed in escaping from metaphysics into physics. For we read in his work that he elevated the ego, the psychophysical individual, to the position of the supreme and most powerful being. Now, if we mean by the term supreme being the most developed member of the cosmic organism, then the human individual is doubtless the highest being known to us. But inasmuch as every fellow-man is an equally supreme being, it follows that two men are more supreme and powerful than one. This relation of power is the basis of the rule of the majority among equals. A society of equals is evidently more powerful than any individual member, and the cosmos, finally, is more powerful than human society and any other phenomenon. Therefore, it is not the individual, who in the last analysis determines the world of phenomena, but it is the cosmos which determines the nature of body and soul of the individual. An egoist, who ignores the interrelation and interdependence of the individual on nature and society, injures himself and the community, and is possessed like Stirner. On the other hand, a man understanding these relations is useful to himself and society, he is a "free" egoist. Stirner is a dogmatist of the priestly order, inasmuch as the priestly point of view is characterized by the habit of alleging that some concrete phenomenon, in this case an individual, is the phenomenon in general. Thus we are entangled in the meaningless dualism of the concrete and the general, while the theory of understanding demonstrates beyond peradventure that the general arose out of the concrete, that the absolute is composed of the relative, the eternal of the temporal, the infinite of finite phenomena.

Since every part of the universe partakes of its infinite 
nature, a finite infinity might appear as an absurd contradiction. But this contradiction is solved as soon as we consider any concrete phenomenon in relation to the universe, in which the former is relative as compared to the absolute cosmos. We arrive at the concept of the infinite only by means of finite phenomena, in such a way that the force of thought is compelled to draw always certain lines of distinction, which on closer scrutiny appear as merely formal ones. For we may positively range one phenomenon after another in line, either downward in the dissection of the atom, or upward in the agglomeration of the universe, without ever coming to a beginning or an end. In the same way we arrive at the concept of eternity by means of incessant additions of time. The concept of an organic universe has at least the same importance for a scientific conception of the world that the changeability of magnitudes to the infinitely small or infinitely great has for higher mathematics, or that the scientific role of the atom is playing in chemistry, or the molecule in physics. The statement of the fact that our mind can take its departure only from objective senseperceptions in order to arrive at general concepts, the revelation of this peculiarity of the force of thought, furnishes us with the basic method for all scientific work, namely, the critically inductive method. We have but to apply this method consistently in order to find that it leads to the dissolution of religion and of all theological, purely deductive and dualistic, philosophies. Religion is then replaced by the organic conception of the world, which satisfies sentimental fantasy as well as sober reason. The religious feeling of infinity and need of a unifying principle are satisfied by the understanding of the organic universe. Speculative philosophy renounces its seat in favor of the science of understanding. The breast 
of man is delivered from the nightmare of all spooks, because at last he may exult freely and acknowledge with modest pride that he is a conscious member of society and of the universe. Dietzgen's theory of understanding completes the victory of Marxism over all priests, philosophers, anarchists and champions of the dualistic method of thought, by supplementing and perfecting the unitary and organic conception of society typical of historical materialism by the monistic conception of the universe. It proves far more thoroughly than the many wellfounded references to the results of natural science, especially of biology, quoted by Haeckel, that the social determinism of typical Marxism for the human individual is substantiated by the determinism of cosmic interrelations. The monism of Haeckel suffers in the first place from the fact that he fancies he can discover the peculiar nature of the force of thought by biological analyses. Haeckel does not understand that his biological researches will, indeed, supply us with proofs of the interielation of mind and body, but can give but scant information as to the peculiar nature of the force of thought. HJe overlooks the fact that the force of thought as such can be studied only by an analysis of its expressions and functions, so that it is the critique of the faculty in action which alone can give us any clues. Apart from the fact that Haeckel has taken little heed of the study of social interrelations and their laws, so that he imagines that he can abolish social evils after the manner of the liberals by first educating the masses intellectually, instead of realizing that intellectual training can produce such results only upon the basis of definite economic conditions, his monism is infected by dualistic spooks especially for the reason that he has not settled his account fully with the crowning result of philosophy, the theory of understand- 
ing. This becomes particularly plain by his Igth thesis for the "organization of Monism," Frankfort on Main, 1904, where he says: "For our modern science, the concept of a god is tenable only on the condition that we mean by 'god' the last unknowable cause of all things, the inscrutable hypothetical 'arch-cause of substance.'"

There we have once again that sad half-heartedness of the so-called free-religious, but at bottom still theological "ignorabimus" of Dubois-Reymond, after the tune of: "Religion, that is to say, bondage to supernatural ideas, must be preserved for the people."

The reader sees, then, that Haeckel belongs to those biased thinkers, who have not become conscious of the absolute premise of thought, the existing natural and objective reality of the universe. We, on the other hand, know, thanks to our understanding of the interrelations of the mind, that the law of causality is necessary to the human mind merely as one of its forms of explanation, and applies indeed to all concrete phenomena of the universe, but not to the universe itself, because the latter is its own cause and effect, without beginning and end, in short the absolute.

We agree to the natural unknowableness of the known final cause of all things. But this natural miraculousness does not apply to the cosmic final cause alone, but also to every one of its phenomena, which are likewise inexhaustible. However, it must be emphasized that this is merely a trivial and natural miraculousness, which is founded in the nature of our force of understanding, for this phenomenon of the universe cannot get beyond the universe, it cannot exhaustively perceive the nature of things either in general or in concrete, and dissolve, as it were, the objective reality of any phenomenon by pure reason. It is because Haeckel does not explain this point 
from the standpoint of a consistent theory of understanding, that his monism retains a last refuge for the mystic faith in a supernatural force of understanding, or a mystic final cause. But Dietzgen's critique of the force of understanding demonstrates, that a supernatural force or cause is an absurdity, as every one may verify for himself. Haeckel is one of the most advanced and frank liberal thinkers. A proletarian conscious of his position in society and the universe is grateful to this prominent scientist for his painstaking research on the field of biology, which furnishes valuable proofs for the world-conception of critical communism. But Haeckel's monistic half-heartedness in matters of the "final unknowable cause of all things" is supplemented on the part of the enlightened proletariat by Dietzgen's monistic theory of understanding. This theory, coupled to historical materialism, offers a reconciliation also to the socalled communist-anarchist, who is interested in the freest possihle development of everybody's personality.

The proletarian conception of the world overcomes among other contradictions also the antagonism between egoism and altruism, for it is critical communism which makes the harmonious development of all the indispensable condition for the development of the individual. Individual powers will reach their highest development only when critical communism will have triumphed. Then the individual will make all others happy, and vice versa. It will be a society of all and of the individual on the solid basis of consciously socialized means of production, which were created by the proletariat and organized by capitalism.

Then begins the era of godless freedom, which proclaims that evolutionary revolution will endure for ever. The egoistic altruists scatter the clerical, liberal, and so- 
cial priesthood. The cosmic dialectics takes root in the heart and brains of men. Objective reality sits victoriously enthroned, and stamps its ruling seal at last, with the conscious knowledge of mankind, upon all terms, conceptions, and actions, which seek favor in the eyes of the majority. Dialectically organized society secures the freest expression to science and art by abolishing the cares for the daily bread. The proletariat is the bearer of this greatest of all social movements ever recorded. The individual who consciously takes part in it, avows to himself: I entrust my affairs to the understanding of the laws of society and of the universe, to which I owe the knowledge that I must develop my personality, not in a struggle against, but in alliance with those social and cosmic interrelations, whose proudiy modest nember I am.

(Translated by Ernest Untermann.) 



\title{
PHILOSOPHICAL ESSAYS
}

\author{
SCIENTIFIC SOCIALISM
}

\section{(VolksstaAt, I873)}

A considerable number of readers of the $V$ olksstaat are opposed to elaborate and searching essays in these columns. I doubted therefore whether the following would be suitable for publication. Let the editor decide. Yet I beg to consider whether it is not as valuable to engage the more advanced minds and to gain qualified thoroughgoing comrades as to strive for great numbers by publishing popular articles. Both these aims, I think, should be kept in view. If the party is really of opinion that the emancipation from misery cannot be accomplished by mending particular evils but by a fundamental revolution of society, it necessarily follows that an agitation on the surface is inadequate and that it is moreover our duty to undertake an enquiry into the very basis of social life. Let us now proceed:

Contemporary socialism is communistic. Socialism and communism are now so near each other that there is hardly any difference between them. In the past they differed from each other as does liberalism from democracy, the latter being in both cases the consistent and radical application of the former. From all other political theories communistic socialism is distinguished by its principle that the people can only be free when they free themselves from poverty, when their struggle for 
freedom is fought out on the social, i. e., on the economic, field. There is this difference between the modern and the older socialistic and communistic theories: in the past it was the feeling, the unconscious rebellion, against the unjust distribution of wealth, which constituted the basis of socialism; to-day it is based on knowledge, on the clear recognition of our historic development. In the past socialists and communists were able only to find out the deficiencies and evils of existing society. Their schemes for social reconstruction were fantastic. Their views were evolved not from the world of realities, not from the concrete conditions surrounding them, but from their mental speculations, and were therefore whimsical and sentimental. Modern socialism, on the other hand, is scientific. Just as scientists arrive at their generalizations not by mere speculation, but by observing the phenomena of the material world, so are the socialistic and communistic theories not idle schemes, but generalizations drawn from economic facts. We see for instance that the communistic mode of work is being more and more organized by the bourgeoisie itself. Only the distribution still proceeds on the old lines and the product is withheld from the people. The small production is disappearing while production on a large scale takes its place.

Those are facts resulting from the economic development of history and not from any conspiracy of communistic socialists. If we define work as an industrial undertaking whose products the worker uses for his own consumption, and an industrial undertaking as the work whose products go to the market, then it is not difficult to perceive how the development of industry must finally result in an organization of productive work. On the 
material organization of society scientific socialism is based.

Scientific socialists apply the inductive method. They stick to facts. They live in the real world and not in the spiritualist regions of scholasticism. The society we are striving for differs from the present but by formal modifications. Indeed, the society of the future is contained in the present society as the young bird is in the egg. Modern socialism is as yet more of a scientific doctrine than of a political party creed, though we are also rapidly approaching this stage. And strange to say, the International is of purely national descent: it proceeds from the German philosophy. If there be a grain of truth in the prating of "German" science, then the scientific German can only be found in his philosophic speculation. This speculation is on the whole an adventurous journey, yet at the same time a voyage of discovery. As the clumsy musket of our forefathers represents a necessary stage to the Prussian needle gun of the present time, so the metaphysical speculations of a Leibnitz, Kant, Fichte, Hegel are the inevitable paths leading up to the scientific proposition, that the idea, the conception, the logic or the thinking are not the premise, but the result of material phenomena. The interminable discussions between idealism and materialism, between nominalists and spiritualists on the one hand, and the realists or sensualists on the other hand, as to whether the idea was produced by the world or the world by the idea, and which of the two was the cause or the effect - this discussion, I say, forms the essence of philosophy. Its mission was to solve the antithesis between thought and being, between the ideal and the material. A proof of this view I find in the fortnightly review Unsere Zeit for the second half of January, 1873 , in an essay on intoxicating 
articles of consumption, as wine, tobacco, coffee, brandy, opium, etc. The author, after having stated that the use of intoxicants was to be found among all nations, at all times and under all conditions of human society, proceeds to declare that the cause of that fact must be looked for there, "where the cause of all religion and philosophy lies, in the antithesis of our being, in the partly divine, partly animal nature of man." This antagonism between divinity and animality in human nature is in other words the antithesis between the ideal and the material. Religion and philosophy work towards a reconciliation of those conflicting principles. Philosophy proceeded from religion and began to rebel against its conception of life. In religion the idea is the primary element which creates and regulates matter. Philosophy, the daughter of religion, naturally inherited a good deal of her mother's blood. She needed ages of growth to generate the antireligious, scientific result, the apodictically safe proposition, that the world is not the attribute of spirit, but, on the contrary, that spirit, thought, idea is only one of the attributes of matter. Hegel, it is true, did not carry science to that height, yet so near was he to it that two of his followers, Feuerbach and Marx, scaled the summit. The clearing up of speculation helped Feuerbach to give us his wonderful analysis of religion, and enabled Marx to penetrate the deepest recesses of law, politics and history. When we see, however, Herbart, Schopenhauer, Hartman, etc., still going on speculating and philosophizing, we cannot regard them as more than stragglers, lost in the phantastic depth of their own thoughts, lagging behind in the back-woods and not knowing that the speculative fire has been overcome in the front. On the other hand, Marx, the leader of scientific socialism, is achieving splendid success by apply- 
ing inductive logic to branches of knowledge which have hitherto been maltreated by speculation. As far back as the year 1620 Francis Bacon declared in his "Novum Organon" the inductive method as the savior from unfruitful scholasticism and as the rock on which modern science was to be built.

Indeed, where we have to deal with concrete phenomena, or, as it were, with palpable things, the method of materialism has long since reigned supremely. Yet, it needed more than practical success: it needed the theoretical working-out in all its details in order to completely rout its enemy, the scholastic speculation or deduction. In his famous "History of Civilization in England" Thomas Buckle speaks at great length of the difference between the deductive and inductive mind, without, as it seems, having grasped the essence of the matter; he but proves what he admits himself in the introduction to his work that, though having made German philosophy a serious study, he did not fully penetrate it. If this happens to ripe and ingenious scholarship, what shall become of immature and superficial general knowledge which deals not with specialties but with the general results of science? In order to indicate clearly the scientific basis of socialism, I venture to enter more fully into the general result of philosophy, into the solution of the antithesis between the deductive and inductive method. But I fear lest the result of metaphysics, so ostentatiously announced, may appear to the reader as somewhat insignificant and commonplace. I beg, therefore, to remind you of Columbus who by means of an egg once for all furnished the proof that great discoveries resolve themselves into an ingenious, yet simple, idea.

When we retire to the solitude of our cell to search there in deep contemplation, or, as it were, in the inner- 
most of our brains, for the right way we want to follow the next morning, we must remember that our mental effort can be successful only because of our previous, if involuntary, experiences and adventures which we, by help of our memory, have taken along into our cell.

That tells the whole story of philosophic speculation or deduction. These philosophers imagine they have drawn their theories, not from concrete material, but from the innermost of their brains, while, as a matter of fact, they have but performed an unconscious induction, a process of thought, of argument not without material, but with indefinite and therefore, confused material. Conversely, the inductive method is distinguished only by this that its deduction is done consciously. Scientific "laws" are deductions drawn by human thinking from empiric material. The spiritist needs material just as the materialist needs spirit. This thesis, when brought out with mathematical precision, is the result of philosophic speculation.

That may appear simple enough, yet even a cursory examination of any of our reviews will teach us how little familiar that truth is not only to our journalists and writers but also to our historians and statesmen who are untiring in their attempts to evolve views and theses not from the existing conditions but from their heads, hearts, consciences, categorical imperatives or from some other unreal, mystical and spiritual corner. The concrete questions of the day are, as a rule, solved by, or with the help of, given material. But in the discussion with Bismarck whether might goes before right or conversely; in the squabbles of theology whether the gods are made by the world or the world by the gods; whether catechisms or natural sciences enlighten the mind; whether history moves upward to a higher stage or goes 
down to its Day of Judgment; in political and economic questions : whether capital or labor creates value, whether aristocracy or democracy is the right form of government, whether we have to work on conservative, liberal or revolutionary lines; in short, in abstract categories, in matters of philosophy, religion, politics and social life, our leaders of science find themselves in the most unscientific confusion. They test human institutions by such principles or ideas as the idea of justice, of liberty, of truth, etc. "We," says Frederick Engels, "describe things as they are. Proudhon, on the other hand, wants our present society to arrange itself, not according to the laws of its economic development, but in conformity with the precepts of justice." Proudhon is in this respect the prototype of all unscientific doctrinairism.

A far superior guide in all such questions is modern socialism. Owing to its philosophical foundation it stands out prominently as a unanimous, firm and compact, method amidst the endless and shifting dissensions of its political opponents of every shade and opinion. What the dogma is to the religious belief, material facts are to the science of inductive socialism, while the views of liberalism are as whimsical and elusive as the ideal conceptions, as the ideas of eternal justice or liberty on which the liberals believe to be safely based.

The fundamental proposition of inductive socialism may be thus formulated: there is no eternal principle or an $a$ priori idea of the divine, just and free; there is no revelation or a chosen people, but there are material factors which govern human society.

Far from bewailing that fact, we acknowledge it as absolutely necessary and reasonable, as something which may be denied by power of imagination, but which cannot be altered, nor, indeed, ought it to be altered. By 
granting that society is dominated by material interests we do not deny the power of the ideals of the heart, mind, science and art. For we have no more to deal with the absolute antithesis between idealism and materialism, but with their higher synthesis which has been found in the knowledge that the ideal depends on the material, that divine justice and liberty depend on the production and distribution of earthly goods. In the wide range of human needs the bodily ones are the most indispensable; our physical needs must first be satisfied before we are able even to think of our mental ones and those of our heart, eye and ear. The same holds good in the life of nations and parties. Their abstract conceptions depend on the way they make their living. Tribes living by warfare and booty have not the same heaven, the same sense of justice or of liberty as our patriarchs are supposed to have had who, as is well known, were living on cattle-breeding. Knights and monks had notions of righteousness, of virtue and honour which were decidedly illiberal and anti-bourgeois, because their means of life were not supplied by factory labor and financial transactions.

Of course, the defenders of Christianity strongly object to those views. In order to prove the independence of spirit from matter and of philosophy from economics they make the assertion that the same Christian truth is invariably taught to all sorts and conditions of men, and under all climes. They forget, however, how they trimmed the sails to the wind. They forget likewise that the love preached by the apostles and churchfathers - the love which gave away the second coat is no more the many-coated love under the overcoat which strips the poor to the skin - of course, rightfully. To the diverse modes of property and trade correspond diverse Chris- 
tianities. The institution of slavery in U. S. A. was Christian, and Christianity was slave-holding there. The religious reformation of the sixteenth century was not the cause, but the effect, of the social reformation that followed upon the shifting of the economic center from the manor to the city. And that was preceded by the rise of navigation and the discovery of the New World and new trade-routes, which indicate the rise of manufacture. Industrial life having no use for ascetic bodies introduced the protestant doctrine of grace that abolished religious exercises in favor of stern industrial work.

That the materialist conception of history is scientific induction and not idle speculation manifests itself even more clearly when we apply it to political party problems. With its help the tangled mass of party struggles can be easily unravelled into a clear, running thread. The squire is enthusiastic over the absolute monarchy because the absolute monarchy cared for the squirearchy. Manufacturers, merchants, bankers, in short, capitalists are liberal or constitutional, for constitutionalism is the political expression of capitalism, which liberalizes trade and commerce, supplies the factories with free labor, promotes banking and financial transactions, and, in general, takes care of the interests of industrial life. Philistines, shopkeepers, small tradesmen and peasants join alternately one party or the other according to the promises made with regard to the promotion of their wellbeing and to the relief from the effects of competition with big capital.

The familiar accusation of political hypocrisy which the Parliamentary parties throw at each other was suggested to Bismarck by one of the renegades of our camp whom he likes to employ. That accusation is based on the recognition that the aristocratic and middle class con- 
sciousness was formed by the material requirements of the landed and manufacturing and trading classes, and that behind their idealistic watchwords of religion, patriotism, freedom and progress lurks the concrete interest as the motor power. I cannot deny that many of their followers are not conscious of their real motives, and that they sincerely believe their political work to be purely idealistic. But I should like to remark that it is with recognitions as with epidemics, they are in the air and people feel them scmehow. Indeed, the political hypocrisy of our time is half conscious, half unconscious. There are many people who take the ideological phrases as gospel truth, but also the artful are by no means rare who want them to be taken as such. The matter can be easily explained. Different classes, distinguished by their different material conditions, succeed each other to political power. The interests of the ruling class are always for a certain time in harmony with the interests of the community, that is with the progressive forces of civilization. And it is that harmony which justifies the ruling class in regarding itself as the spring of social welfare. However, the onward march of history changes everything, also the justification for ruling power. When the economic interests of the ruling class cease to be in harmony with the general welfare, when the ruling class loses its functions and falls into decay, then its leaders can only save their predominant position by hypocrisy; their phraseology has been emptied of all reality. It is no doubt true that some individuals rise above class interests and join the new social power which represents the interest of the community. So did Abbé Sieyès and Count de Mirabeau in the French Revolution, who, though belonging to the ruling classes, became the advocates of the third Estate. Still, these are excep- 
tions proving only the inductive rule that, in social as in natural science, the material precedes the ideal.

It may appear rather contradictory to make the Hegelian system of philosophy with its pronounced idealism the starting point of the materialist conception of history. Yet, the Hegelian "Idea" is striving for realization; it is indeed a materialism in disguise." Conversely, the Hegelian reality appears in the mask of the "Idea," or of the logical conception. In one of the latest issues of Blätter für Unterhaltung Herr J. Volkelt makes the following remark: "Our modern thinkers have to submit to the crucial test of empiricism. The Hegelian principle has no reason to be afraid of such a test. Consistently followed up it means that the spirit of history can only be conceived through the existing material." Gleams of truth like these we can find now here and there in the periodical literature, but for a consistent and systematic application of the theory we must go to scientific socialism. The inductive method draws its mental conclusion from concrete facts. Scientific socialism considers our views dependent upon our material needs, and our political standpoint dependent upon the economic position of the class we belong to. Moreover, this conception corresponds with the aspirations of the masses whose needs are in the first place material, while the ruling class must necessarily base itself on the deductive principle, on the preconceived unscientific notion that the spiritual salvation and the mental training of the masses are to precede the solution of the social question. 


\title{
THE RELIGION OF SOCIAL-DEMOCRACY*
}

\author{
SIX SERMONS \\ (VolksstaAt, 1870 to 1875 )
}

I.

Friends and Fellow-Citizens: The teachings of Socialism contain the material for a new religion which, unlike any other religion, appeals not merely to the heart and emotions, but at the same time to the brain, the organ of knowledge. From all other earthly knowledge socialism is distinguished by its religious form, by its fervid appeal to the heart and soul of man. Generally speaking the object of religion is to save the suffering soul from the gloom and misery of earthly life. This object it has thus far realized only in an unreal and fantastic manner, by referring us to an invisible God and to a Kingdom inhabited by ghosts. The gospel of to-day promises to save us from misery in a real and palpable way. God, that is the Good, the Beautiful and the Holy, is to be made man, and is to descend from heaven unto the earth, not as in the days of old in the flame of religion and in the spell of wonder, but in reason and reality. We want our saviour, our Word, to become flesh, and to be materialized not in one individual only. All of us desire, the people want to become sons of God.

- Used here and later on in the wider sense of the word as the most prominent representation of militant Socialism. The reader may, therefore, safely change "The Religion, Ethics and Philosophy of Social Democracy" into: Socialism and Religion, Ethics, Philosophy.- Edrror. 
Religion was until now a matter for the dispossessed. Now, however, the matter of the dispossessed is becoming religion, that is something which takes hold of the whole heart and soul of those who believe. The new faith, the faith of the proletariat, revolutionizes every thing, and transforms after the manner of science, the old faiths. In opposition to the olden times we say, Sun, stand thou still, and Earth, move and transform! In the old religion man served the gospel, in the new religion the gospel is to serve man. In order to emancipate humanity from religion not only vaguely but distinctly and really, it is necessary to overcome religion by analyzing and fully comprehending it. The new gospel asks for a thorough 'revision of the whole system of our thought. According to the old revelation the law was the primary, the supreme and the eternal, and man the secondary element.

According to the new revelation man is the primary, the supreme and the eternal, and the law the secondary, temporary and transitory element.

We do not live for the sake of the law, but, on the contrary, the law exists for our sake, to serve us, and to be modified according to our needs. The old gospel required of us patience and submissiveness; the new gospel requires of us energy and activity. In the place of grace it puts conscious work. The old bible was named authority and faith; the new has for its title revolutionary science.

Faith and science, my dear friends, form the contradiction which separates the old from the new gospel. Those who have clearly grasped this distinction are incipient socialists, even if they have not penetrated to the political or social consequences springing from it. This distinction between faith and science contains the germ of revolu- 
tionary development. Both pursue the same end, the salvation of mankind, yet their ways are as poles assunder. Faith refers us to fancy and imagination, science to reason and reality.

Our opponents, the scribes and pharisees of the old gospel, stand and fall with the dogmas of their faith; they are past redemption. Those, however, who stand on the ground of science, submit their judgment to the crucible of facts; they are the followers of the new gospel. The struggle between faith and science, the antagonism between the old and the new gospel, dates by no means from the days of socialism. It goes back to the ancient world, to the beginnings of scientific research, then it revives with the renaissance and grows more and more with the approach of the present era where it finds its embodiment in our leaders of scientific thought, though it reaches its full development only in the modern labor movement.

All great movements of the past were but the forerunners, the preliminaries of the general movement, of the coming great revolution whose birth we are witnessing. Greek civilization and Christianity, the Reformation, the French revolution of 1789 , philosophy and modern science are mere instruments, but industry is the great architect, and socialism the lofty structure which the nations of our time are rearing. The history of the past has diligently collected the necessary materials, and now, friends, the time has come to dig up the soil and to lay the foundations.

Valuable as the labors of the past may be, they are but fanciful ornaments in comparison with the fundamental work the future has to carry out.

"Man is free, even were he born in chains." This saying of Schiller needs correction. For man is born in 
chains and must struggle for freedom. The heaviest chains, the strongest fetters were put on him by Nature. Against her tyranny he struggles from the beginning of his days. Sustenance and apparel he must wrest from her. The whip of dire necessity in her hand she stands over him, and on her whims and frowns his existence depends. It was the tyranny of Nature which gave religion that predominant influence over the soul of man. Religion promised him relief from the heavy hand of Nature. How long and anxiously did Judaism wait for the Kingdom of the Messiah! "Consider the ravens: for they neither sow nor reap; which neither have storehouse nor barn; and God feedeth them; how much are ye better than the fowls?" Praying and fasting are the means recommended by Christianity against the inborn helplessness of man. Through the whole of the middle ages that advice was faithfully acted upon, until its futility became manifest. With the appearance of Luther religious thought changes. $\mathrm{He}$ proclaimed that Christ had performed for us in heavenly grace our religious salvation, thus relegating sacred exercises to Sundays chiefly and giving free the week-days for sober work. His challenge to the medieval Church heralds the era of industrial activity. Even though his followers afterwards misrepresented his teachings and though Luther himself left his work but half finished, it is nevertheless true that with the Reformation man starts out on a new earthly practice, the salvation through Labor. without exactly giving up his theories about heaven. He works, accumulates wealth, and with the accumulated wealth he rises to the height of a new conception, to the gospel of social salvation.

Religion has since time immemorial been so much cared for and hallowed, that even those minds who have 
given up the belief in a personal God, in a supreme protector of mankind, still adhere to some sort of religion. Let us for the sake of those conservatives use the old word for the new thing. This is not only a concession made to prejudice in order the more easily to overcome it, but is also justified by the thing itself. Indeed, religions differ not more nor less from each other than all of them from the anti-religious social-democracy. All religions have this in common, that they strive for the salvation of suffering humanity, and to lead it up to the good, the beautiful, the righteous and the divine. Well, social-democracy is all the more the true religion as it strives for the very same end, not in a fantastic way, not by praying and fasting, wishing and sighing, but in a manner positive and active, real and true, by the social organization of manual and mental work.

Work is the name of the new Redeemer.

Christ made a great number of proselytes long before the church was established, so did in many centuries the new redeemer, Work, before he could in our present age think to ascend the throne and to take the sceptre into his hand. Now he is endowed with the attributes of the Godhead, with power and knowledge. He did not come to his glory in an immaculate and miraculous way. He is born in pains, and grown up in struggle and affliction and sorrow. Although it is he who civilizes man and cares for him, and comes with the promise to fully release him from the bonds of slavery, and actually shows him the longed-for new land from afar, yet the crown of thorns is on his brow and the cross of contempt on his shoulders.

However, let us drop parables and allegories, and do away with metaphorical language. The thing is much too great and too prominent to need mystical drapery. 
We deal here with the salvation of mankind in the truest sense of the word. If there be anything holy, here we stand before the holy of holiest. It is neither a fetish nor an ark of the covenant, neither a tabernacle nor a monstrance. It is the real, positive salvation of the whole civilized humanity. This salvation was neither invented nor revealed, it has grown out of the accumulated labor of history. It consists in the wealth of today which arose glorious and dazzling in the light of science, out of the darkness of barbarism, out of the oppression, superstition and misery of the people, out of human flesh and blood, to save humanity. This wealth, in all its palpable reality, is the solid foundation of the hope of social-democracy.

The wealth of to-day does not consist in the superb mansions, inhabited by the privileged of society, nor does it consist in their costly apparel, or in the gold and the precious stones of their jewelry, or in the heaps of goods peeping through the show windows of our great cities. All that as well as the coin and bullion in the trunks and safes form but an appendix or, so to speak, the tassels and tufts, behind which the wealth is concealed - the rock on which our hope is built.

What authorizes the people to believe in the salvation from the long ages of torture - nay, not only to believe in, but to see it, and actively to strive for, is the fairylike productive power, the prodigious fertility of human labor. In the secrets which we have wrung from $\mathrm{Na}$ ture; in the magic formulas by which we force her to do our wishes and to yield her bounties almost without any painful work on our part; in the constantly increasing improvement of the methods of production - in this I say, consists the wealth which can accomplish what no redeemer ever could. 
All exertion and struggle in human history, all aspira. tions and researches of science find their common aim in freedom of man, in the subjection of Nature under the sway of his mind.

What is freedom? Is it a phantom of which the German poet Schenkendorf sings, "Freedom as I understand it," and of which, strictly speaking, only the name is known; after which the revolutionists of 1848 were hankering, like a boarding-school miss after some chivalrous knight? And verily, also those have but a philistine conception of its sublime character, who but see in it freedom from police interference or freedom of competition, of conscience, of speech, of organization and of public meetings. All that is but the fringe of freedom. Our Liberals and Progressives, who only fight for that tinsel, have long ago deprived the people of all reality of freedom which they consider as their exclusive privilege. What we want and what the Liberals largely possess in superabundance is freedom from the bonds of slave-labor, freedom from poverty, misery and sorrow, freedom from starvation and ignorance, freedom from the curse of being the beast of burden to the "higher classes" - this freedom for the masses of toiling humanity is the sacred aim which modern society could attain to by the infinite productivity of human labor.

Man, to be sure, is still dependent on Nature. Her tribulations are not as yet all overcome. Culture has yet a good deal to do; aye, its work is endless. But we have so far mastered the dragon, that we finally succeeded in forging the weapon with which it can be subdued; we know now the way to tame the beast into a useful domestic animal. From praying and fasting we have turned to thinking and working. The result of the 
change of method is plainly visible in the conquests of modern industry, whose soul is the productivity of our labor.

The hardships of mankind were perhaps until now inevitable, considering that there was no power to mitigate them. It certainly required thousands of years of development to bring forth that power. As long as the labor of the people was not fruitful enough to satisfy the needs of the masses, certain classes could usurp the privilege of governing the land. I am even inclined to go further and to admit that the task of developing our labor power to that degree of prodigious fertility which we see to-day, has necessitated a privileged governing class as well as the exploitation of the masses. I am thus ready to acquiesce patiently in the misery of the past, and bear it no grudge or malice. But all the more I am now justified in pressing forward the claims of social-democracy. The people are striving for real salvation, because the conditions are ready for it. Poverty, starvation and misery in the past were quite often the inevitable results of the deficiency of production. Now, or to be more accurate, since the second decade of the nineteenth century the case is quite the reverse: it is the superfluity of wealth, as manifested in the recurring periods of commercial and industrial depression, which interferes with production. However full the granaries and warehouses may be with goods of all kind, the people starve and freeze, because the possessing classes, satiated with wealth, do not require their labor power. The world is over-populated (hear! hear!), say our professors and politicians. Yes, the world is over-populated, because the means of sustenance can be so easily gotten. Human history had until now the task to organize production, to unfold labor power, to economize, and to produce wealth. 
To achieve that purpose, civilization used man ruthlessly as a tool. As far as that task can be fulfilled by means of oppression, it has been fulfilled. Civilization was until now the aim, and man the means of history. The time has now come to revert the case and to make man the end, and civilization the means. The prime necessity to an advance in civilization is freedom of the people to participate in consumption. Only occasionally and exceptionally there is suffering from a lack of supply, but generally and as a rule we witness misery caused by an abundance of goods in quest of consumers. Owing to free competition this abundance, called national wealth, has been the means to reduce prices and thus to stimulate advanced methods of production by the introduction of labor and cost-saving machinery. However, in consequnce thereof those who were unable to compete went to the wall and the purchasing power of society decreased. So it came about that wealth, once the stimulator of progress, is now turning into a factor of historical stagnation.

Some of you, dear friends, may think that I see something which is not warranted by fact. However great wealth might be, it was by no means so abundant as to stifle production and to deprive the laborer of his employment.

To be sure, new factories are being built and the old ones prosper; new railways, shipping lines and canals are being opened, and the land does not go out of cultivation. Yet all this is but the appearance, and not the reality of things, because truth is veiled by seeming contradictions. He who has eyes to see, sees the general tendency, despite the particular contradiction he sees the superfluity and the retrenchment of industry, despite the fact that the chimneys continue to pour forth smoke. 
What does not move as rhythmically as its nature requires, is lame. And who could deny that there is both the need and the power to expand production to many times its present dimensions? No matter how great or small the present improvements of agriculture or of machinery may be, on the whole it must be admitted that the growth of production is kept in check by the question of consumption. The salvation of humanity is involved in this question. It is so great and sublime, that all other problems which time may bear in its folds must wait in silence. The whole of old Europe is waiting with bated breath for the fulfilling of things which are coming.

The political events are but the surface, but a ripple of what is raging in the depths of history, at the bottom of social life. He who has eyes to see, sees how every rising tide of freedom has in the last decades been thrown back by an ebb twice as strong. In all leading countries of Europe every political step forward is followed by a forcible reaction. The tri-colored freedom alternates with Caesarism, Republics with Empires, lively enthusiasm with flabby apathy, each new era of liberalism is followed by a Bismarck. The English Parliament disestablishes the Irish Church and carries Crimes Acts which exceed in severity Prussian martial law. France, in the person of M. Ollivier, ${ }^{1}$ shows a strange attitude. Standing fast on one leg, she moves the other forward and backward, as if working the spinningwheel of time. The wheel is diligently kept in motion, but no yarn comes out of it. Neither in Paris, nor in London, neither in Madrid nor in Naples, neither in Berlin nor in Vienna. $O$, ye short-sighted and narrowminded, who cannot give up the fad of the moderate organic progress! Don't you perceive that all your great

\footnotetext{
1 This was written before the outbreak of the Franco-Prussian War, 1870.
} 
liberal passions sink to the level of mere trifling, because the great question of social salvation is on the order of the day? Don't you perceive that struggle and destruction must precede peace and construction, and that chaotic accumulation of material is the necessary condition of systematic organization just as the calm precedes the tempest and the latter the general purification of the air? Neither the emancipation of nationalities nor that of women, neither the reorganization of school nor that of education in general, neither the reduction of standing armies nor that of taxation - neither of those demands can be satisfactorily taken in hand before the working class is freed from the fetters which keep them riveted to starvation, sorrow and misery. History stands still, because she gathers force for a great catastrophe.

Social-democracy believes in the conquering power of truth, hopes for the salvation from material and mental slavery, and deeply desires justice for all.

The practical and the successful, the pharisees and the scribes, the selfish and the hypocrites think us therefore hopelessly fantastic. They argue that there have always been lucky and unlucky, rich and poor, master and servants, and they illogically conclude that this state of things will endure forever and ever. They don't conceive the possibility of salvation, because they don't understand the people. The people are not a mass of pleasure-seeking loafers. They despise the finery of your pseudo-culture. They desire a systematic organization of our economic life which shall make impossible the gluttony of the few and the privations of the many, but which shall secure plenty of the necessaries for all. Our kingdom differs toto coelo from yours. And your kingdom, the social order of to-day, have you constructed it consciously, or is it not true that you have 
organized it instinctively, experimentally, in the course of centuries? Consider the frugal needs of our people and at the same time the modern fertility of labor, and ask yourselves if the instinct alone would not be sufficient to teach us how to supply adequately our needs with the help of the existing means of production? However, socialdemocracy does not rely on instinctive feeling only. In contradistinction to the present system of production which works without clear purpose and measure, socialdemocracy is based on a clear comprehension of the scope and the tendencies and the aims of modern economic life according to which it consciously attempts to reconstruct human society.

Conscious, systematic organization of social labor is the redeemer of modern times.

\section{II.}

Before we proceed with our thesis let us, dear friends, sum up in a few words the essence of our first sermon. In the social-democratic movement we have found a new form of religion, inasmuch as both are striving for the same end: the salvation of man from poverty with which he helplessly began his struggle for existence in the midst of a world of adversities. Even the most superstitious soul cannot claim for religion more than the success of spiritual salvation. The pagan gods have scarcely any share in that spiritual world, while the Tri-personal God of Christianity could only mitigate the misery of the people by making it a virtue. I shall not deny that this doctrine was beneficial for a time. As long as man had neither the capacity nor the means to throw off his cross, resignation was not only a divine balm, but also an effective discipline which trained him for the rigorous 
mental work civilization requires. Mind was cultivated by religion. But what purpose could such a culture serve if it didn't enable us to cultivate the real world and to improve material conditions with the help of the mind? I am quite aware, my friends, that Christianity disowns this only earthly reason of its existence; I am quite aware, that Christianity claims its Kingdom not to be of this world, and that its only mission was the salvation of our immortal soul. We know, however, that we do not always achieve what we intend to achieve, and that we don't really always do what we mean to do. We distinguish intentions from realizations. And the materialistic social-democrat has made it his special duty, to judge people not by their flashes of thought, but by their palpable actions. Indeed, the aim of religion can only be attained by material culture, by a cultivation of the material. Work we called the redeemer of humanity. Science and mechanical arts, mental and manual labor, are, like God-father and Son, two different forms of one and the same being. This truth I should like to call the cardinal dogma of the social-democratic church, if social-democracy could be called a church, and reasonable knowledge a dogma. Science has been an idle speculation as long as it didn't reach the truth that thinking, perceiving and learining required external objects and sense-impressions. The combination of the activity of the brains and the senses distinguishes natural science from all ancient speculative sciences. The science of the ancients was largely speculation, that is, they believed it possible to evolve truth by mental activity alone, without the help of external objects and experience. But the result thus obtained was no science. No wonder, that the contents of many a library of folio-volumes with their wooden and pigskin bindings have now chiefly an antiquarian value. 
On the other hand, the craftsmen of the past did not sever manual from mental labor, and though their handwork has largely been consumed or damaged, yet the science of those practical investigators has been carefully guarded by tradition and handed down, nearly unimpaired, from generation to generation. There are among us a good many people who, instead of regarding science as a handmaid to civilization, idolize and worship it with boundless and servile admiration as something preternatural. They are like the barbarians who turned the natural and social law into a divinity and thus deprived themselves of the power to control that law and to use it for the benefit of mankind. It is incumbent upon social-democracy to destroy both the religious and the scientific superstition. Man shall not look up to science, but shall draw it down to earthly purposes. The mental shall be the tool of manual labor. With this we by no means disparage the just claims of science. The manifest futility of mere speculative brooding, the demonstrated barrenness of pure reason, may be a lesson for the learned profession, that there can be no science without the action of our senses upon material objects. Conversely, let the craftsmen learn from the wonderful results of modern industry that labor needs the co-operation of science.

The mutual permeation going on for centuries of those two forms of activity helped humanity to reach that point where the foundation-stone to the temple of social-democracy can be laid. It consists in the power of our material production, in the productivity of modern industry. But let us take care not to think in this connection of mental power only! The labor, which has been accumulated in the course of ages, does not consist of mental or scientific achievements only, but to a 
much higher degree in the material wealth existing around us, insofar as it constitutes a necessary instrument of modern labor. Although this instrument or wealth is at present under the control of private individuals, yet the social-democrat must learn to conceive that it could not be the creation of private efforts. All our material wealth as well as our scientific and literary achievements can only be due to the collective work of many and various generations, countries and races, and is therefore, despite the private control under which it is at present, the collective product of all.

Great inventions and discoveries, which are bound up with certain names, are but nominally the property of those famous individuals. They are in fact, like the material achievements, the result of collective labor, the product of society. And it is but a survival of the barbarian past to regard great historic names not only as brilliant leaders, but also as demigods, though such opinions are still prevalent among many learned as well as ignorant men. To be sure, had not Columbus made use of the accumulated means, ideas and aspirations to undertake the discovery of America, some other sailor would have done it; the talent and courage requisite for such a voyage are by no means rare among sailors generally.

Or as Thomas Buckle says of James Watt, the inventor of the steam-engine: " $\mathrm{He}$ would have surely not achieved what he has, without his predecessors." This may be applied to all men who distinguished themselves and achieved great successes as well as to common people.

It is, dear friends, the supreme duty of science to reduce the extraordinary, i. e., which appears to the general superstition as extraordinary, to the level of the ordi- 
nary, the usual, the natural or normal. The saints and the sanctuaries, the religious and the worldly ones, must disappear in order that the only eternal and true sanctuary: humanity or mankind, may live. To make brotherhood a reality; to make it impossible to despise any one, it is necessary to cease to humbly look up to any one. The social-democrat should not stare at the chief of a republic as the peasant does at the priest; he should not regard him as a biped God, as the chosen supreme master. We are all born chiefs, while the elected chief is simply the temporary administrator of the ordinary state of affairs, the business manager the like of whom there are hundreds among the people. The tribe of David should intermingle with the tribe of Melchizedek and form one tribe of citizens with equal rights.

Let us now return to the doctrine of our social-democratic church, the foundation-stone of which is the accumulated material and mental wealth, and which teaches us to believe that that heavy stone had been hewn and brought to light neither entirely without nor altogether by the effort of certain select individuals and noble families, but by the exceedingly hard labor, material and mental, of the whole society. Only knaves and fools call this a system of crude levelling-up. Those, however, who have studied our church-fathers know that our social hierarchy, the difference between the great and the small, the virtuous and the wicked, the noble and the common, the learned and the untaught, have only been established in order to endow the few with privileges and to keep the masses in servitude. No, fellow-citizens! the equality of social-democracy is by no means a fantastic equality. It does not exclude diversity. Nature has given us the same desire to satisfy our hunger, to clothe our body and to develop our capacities. Men have always 
and everywhere the same imperious instinct of self-preservation and the same desire to live in enjoyable activity, without misery or servitude. The equality in the desire does not interfere with the natural diversity, with the peculiar talents and proclivities given to each of us. Just as in nature as a matter of fact equality and diversity intermingle and form one united whole, so will the social order of the future make all men equal in rank and value, by giving them the equal right to the enjoyment of their individual life, without obliterating the diversity which requires of every one to act according to his gifts. A new era has dawned upon mankind. It bids us approach its message in the light of new ideas and a new understanding.

The first and foremost thing in this respect is to revise our present notion of the supreme being and our idea of perfection. Until now we have been taught to regard and to revere the sublime, the supreme, the divine and the perfect as a single thing or being. Here the barbarians found it in a tree, there in a golden calf, then in the thunder and lightning as the fierce justice, finally the Christians deified the spirit of love. Why was the spirit of love so imperfect? Because he lacked the antithesis, the flesh and bone. We shall give him reality when we search for the perfect, the great and sublime not in one single thing, nor in one single quality, nor in one particular personality, but in the communion and intimate connection of all men and things. Various peoples and various ages idolized the most diverse things as the supreme perfection. Here it was bodily strength and martial prowess, there it was Samaritan pity and spiritual power. But none of these single things has stood the test of time. The deified qualities have proved to be as transient as the gods themselves, and as the peoples who 
have for a long time been looking for the true God, until the truth has forced itself to the front that men as well as things are all equally sublime, equally perfect and divine. I hear already the shrill voice of the heretics, i. e., of the adversaries of our gospel, charging us with iniquitous blasphemy. Our respectable citizens cannot perceive a state of things without masters and servants, without nobles and commoners, without virtuous and wicked. They think it quite strange to ascribe the same value to the crooked as to the straight, to the donkey as to the miller. Verily, I tell you, the more reasonable the miller the more will he value his donkey. Both of them are in this point equal, that they serve each other, and that either of them is, in the right time and the right place, a valuable part of a united whole. Only that and no more is the meaning of the social-democratic doctrine of equality. The privileged divinity of the individual must be abolished if the general deviltry should once for all be done away with. Nothing shall be rejected as impure, everything shall be worthy of a place in the tabernacle, that it may be able, in its time and station, to serve for the best of all. Humanity, knowing how to live in mutual service and to supplement one another with the things of this world, is the bodily representation of the supreme being and of divine perfection.

The social-democratic equality, my friends, is therefore something quite different from the insipid political equality to which the liberal parties want to treat the people. They want political equality, that we may help them to establish a state of things in which they could use us unreservedly for the preservation and augmentation of their wealth, while the aim and end of our equality is to restore the wealth to those who in the course of centuries created it by hard, ceaseless toil, namely, to the 
people. The wealth of to-day is the instrument of future labor. In the present it serves private ends, in the future it shall serve social ends. The restoration of that instrument to the people shall not take the form of a division. It shall not be divided up in the manner which obtains to-day, where some get more than their due, while some get nothing at all and are consequently forced into the servitude of the rich; nor shall it be divided up in equal but petty shares so that each individual is to start out on his own hook on a life of drudgery, or is to run the risk of being cheated out of his heritage by the jugglery of the cunning. No, that instrument shall not be subjected to any partition, but it shall be handled with organized skill by co-operative labor; the product only shall be divided and consumed. That is the communism of social-democracy.

While Nature ruled with the overpowering force of fate or of a god, and cowed humanity into poverty, it might have been useful to entrust certain individuals or certain classes with the power of government that they might serve as guides for the people. The ancient, the feudal and to-day's bourgeois order of slavery are progressive steps to the organization of labor. Now, however, the time is approaching which calls upon us to take a much farther step than the liberal and democratic parties are dreaming of. By the productivity of labor the people have arrived at the point where they want that all class-domination shall cease. They feel themselves competent to continue the economic development without the help of privileged leaders. The liberty, with which the bourgoisie goads the people into a struggle against the landed interests or against bureaucracy; the equality and fraternity, which priestcraft promises us with the purpose of binding us to it with ropes of superstition, 
turns into the real liberty, equality and fraternity of social-democracy.

If religion consists in the belief in supernatural beings and forces, in the belief in gods and spirits, then socialdemocracy is without religion. In its place we put the consciousness of the insufficiency of the individual, who needs therefore to his completion and perfection the cooperation of the whole, and consequently acknowledges his submission to the whole. Civilized human society is the supreme being in which we believe; on its transformation to socialism we build our hope. Such a humanity will make love a reality, of which the religious enthusiasts have only been dreaming. The deluded and the obdurate, who cannot believe in the social-democratic development of society, may feel the necessity of transferring their hope from this earth to a Hereafter. Not so the social-democrat. In order to really participate in the consolation which the believer finds in the idea of a heavenly father who protects and defends his children, we are striving for a society which shall assist the helpless individual in all his needs. We call upon society and by virtue of its accumulated wealth we are entitled to call upon society - that it shall vouchsafe to each of its members not only work, but also daily bread, and that it shall feed the hungry, clothe the naked, care for the sick, in short, it shall carry out the work of love and mercy. We appeal to society, not only to call itself human but to be human. In the place of religion, socialdemocracy puts humanity, which shall no more rest on the basis of an ethical commandment, but on the recognition that its savior can only be found in co-operative, brotherly work: in economic communism. The original sin, from which mankind has been suffering, is selfishness. Moses and the prophets, all religious founders 
and legislators together have been unable to extirpate it. "The sin dwelleth in the flesh as the nail in the wall." No preaching or teaching and commanding could eradicate it, for the whole constitution of our present society hinges upon that nail. Bourgeois society rests on the selfish distinction of mine and thine, rests on social war, on competition, on the cunning devices of getting the best of each other.

In conclusion let me point out the moral : it demands and its whole being depends on this demand - that we reconcile the antithesis between love and selfishness; that we constitute our society on this reconciliation; that men shall join hands and with united strength and labor force Nature to yield us our daily bread in plenty.

\section{III.}

Friends:

Before we proceed to deal with the meaning of the moral, drawn from our previous remarks, I should like to call your attention to the essential characteristics, to the great and general outlines of religion. I shall not speak of any special denomination: neither of the Christian, Jewish, Mohammedan or pagan beliefs, but of idolatry in general.

We have found that religion and social-democracy have this in common, that they both strive for salvation. Yet, social-democracy is in this respect more advanced that it does not look for salvation in the realm of spirit, but in the world of material realities, taking human spirit only as its guide. The need for salvation, the misery of the primitive man is the psychological germ out of which religion evolved. This perplexity and helplessness in the midst of a world of adversities causes man to look for omnipotence and perfection in some other quarters, 
and suggested to him the worship of animals, stars, trees, lightning, winds, certain heroic personalities, etc. But eventually in the long run experience inevitably taught him that those things are themselves powerless. Man took a step further and looked for the supreme being no more in near-by and tangible things, but in a spirit reigning in the clouds. Removed from experience as the new godhead was, it became more difficult to get some reliable information about it. Yet modern science, which succeeded in fathoming many a mystery, penetrated also to the bottom of the secret of religion.

The "wealthy and cultured," whose care for science extends but so far as it helps them to accumulate treasure and to preserve their privileges, are in fact the mean materialists to whom nothing is of more serious concern than the selfish cultivation of the body. It is these people who are fain to declare that we must not discuss religion, as nothing could be known about it. Against all such assertions I may assure you, friends, that religion, despite its obscurity and lofty mysteriousness, did not escape the piercing eye of science, which penetrated into its most remote and darkest corners. Just as we know as a certainty that two and two equals four, or that there are no two mountains without a valley, on earth or in heaven or anywhere else, so do we know what and who religion and God are, where they begin and end, where they come from and how they dissolve.

The ruling classes and their conscious or unconscious flunkeys have an interest to contend against the austerity of religion, as it interferes with their worldly enjoyments. For those who really believe and trust in an eternal treasure which is eaten neither by rust nor by moths, lose their appetite for the evanescent joys of the world. Indeed, religious as well as political liberalism is closely 
connected with property and with the mode of business prevailing to-day. The aristocratic families of the past were the friends and followers of the monks, for both had their kitchen and cellar supplied by socage and tithes. The great houses of the present, which "earn" their sumptuous living by profit-making off the labor of others, and this on so liberal, i. e., plentiful, a scale, are more than alienated from the orthodox preacher of Christian discipline and sobriety; their attitude towards him is full of antipathy. Yet it would be a mistake to assume that liberalism is serious in its unbelief. They can't be serious. Their privileged social position condemns the " wealthy and cultured" to that nauseous luke-warmness, to that indifferentism which is neither cold nor warm. Their religious freemasonry, their protests against superstition - by the way, all belief is superstition - cannot be serious, for the religious discipline is one of the mainstays of class-rule. Though they have lost all belief in God they never tire of reminding us of his commandments: "Render unto Cæsar the things which are Cæsar's - . Be subject to principalities and powers, obey magistrates . . . Pray and work . . Bear the cross in all humility and patience . . ." While they are fiercely striving to climb up the ladder of might and wealth they actually delude us, and perhaps also themselves, into believing that they trust in God, who is supposed to humble the proud and to exalt the humble. The liberal bunglers are easily to be recognized as religious hypocrites. The great captains of industry, with their liveried and titled flunkeys as professors, justices, lawyers, etc., are passionately devoted to freedom of trade and competition as well as to freedom of religion. Every man shall be free to believe as his conscience dictates. But woe to those who try to live up to such 
maxims and free themselves of all religion! You may belong to a nonconformist congregation or to an undenominational school. But to have no religion at all, or to belong to a secular school - why, that's positively disgraceful! That's past all bearing! Such things must be put a stop to! If the people do no more believe in anything, who will sanctify our property and supply the dear fatherland with food for guns or cannon?

The small craftsman who feels and sees that the industrial revolution is undoing him, does not know and does not want to know of the inventions and discoveries of science. This is quite the case with our "wealthy and cultured" in matters of religion. They are used to say: If there is no positive proof for the truths of religion, there is still less any proof against religion. Because their interests are endangered by such knowledge, they refuse to admit that more than half a century ago Feuerbach particularly had brought the conclusive and irrefutable proof that all religion is simply a substitute for human ignorance.

The human race has this peculiar distinction, that at different times and places it values different things and qualities as the highest beyond all measure; - that, unlike the apes which but imitate what was shown them, humanity revolutionizes its highest standards, in short, it makes history. Of course, not that history as taught in our schools, which is simply a miserable index of the births and deaths of princes; an enumeration of wars, battles and treaties, while its real import consists in the great and solemn evidence that mankind, its generations and peoples, constitutes a living and continually developing organism, each part of which serves the whole. The aim or postulate of this development is to subdue all existing matter and forces to human needs, to cultivate 
nature, and to bring system into the world with the help of our mind. This process is going on slowly, by fits and starts. Those who by the study of nature and by the insight into its boundless possibilities attained to a wise humility, recognize without hesitation that the historic progress, though its aim is to make human consciousness the lord of the world, is still far from being a matter of consciousness. It is much more the instinct, the nature of matter, which impels its continual development, through the various geological periods to the formation of life, which began with the most primitive lifecells and developed to higher forms with plants and animals by variation and natural selection, until its highest product, man gifted with reason, was brought forth: The end and aim of the evolutionary process is to comprehend the manifold phenomena of nature and history in order to enable man to consider and to use the human race, its ethnological and political organizations and all existing mental and material energies as an organic whole. In the course of his development man passionately idolized anything that happened to range high in his estimation, be it an animal, a plant, a star, a human being or a law. God - the essence of religion - appears thus as a changeabla and temporary, and not as a permanent and eternal, character. The divine has changed so often that its evanescence became manifest to the scientific mind. Science has therefore formulated the proposition: That which religion values beyond measure is in historic reality but temporarily and locally valuable.

Religious people are wont to assert that all races, savage or civilized, have some sort of religion and believe in God. From which they infer that religion is inherent in man and needs, therefore, no further demonstration. That assertion is, however, only in so far truc as oeople 
without experience are credulous, and all the more so, the less experience and culture they possess. Nowadays it is but peasants and women that are the true believers. Those who have eyes to see perceive that there is not one, but many religions, and not one God, but many Gods. As man attains to the understanding of the world only by degrees, he idolizes many things, to-day the sun, tomorrow the moon, one time the dog, as the Persians, at another time the cat, as the Egyptians, until he finally gains the social-democratic truth that nothing and everything is divine, nothing and everything does invaluable services. What the heathen valued in their gods, in Bacchus - wine, in Venus - love, etc.; what the Israelites valued in Jahve - the punishing, reproving and lawmaking; what the Christians worship in their God - the incarnation, suffering and dying for others, boundless love and mercy, contempt for worldly matters, abstemiousness, celibacy, etc. - all this, my friends, is to be valued temporarily and locally, but never to be idolized. Not the objects of religion are reprehensible, but the essence of religion, which is boundless and inordinate in its veneration.

The essence of religion consists in this, that certain phenomena of nature and history, which, according to time and circumstances, acquired an unusual importance, have been personified and put on so high a pinnacle that they appear to be independent of time and space.

The religious truth is but a natural truth standing on its head. Not God created man, but always and everywhere man created God in his own image. If some outof-the-way people, possessed of wisdom, happen to get the sacred books of our churches, they will learn nothing about God and heaven, but a good deal about the civilization of men who wrote and esteemed those things. How 
near our time is to giving up all religion, is evident from the vague and confused ideas now circulating about God and his attributes. While man comes to the knowledge of the existence of all other things because he had known before how and what they are, he wants to be convinced of the existence of God before knowing anything in particular about his nature, whether he is of human or inhuman form, small or large, black- or blue-eyed, male or female. The theologians, being themselves in the dark, label such questions materialistic and improper. But the more advanced thinkers know already that the very few things their colleagues assume to know about God when they qualify him as just, good, wise, almighty, etc.- that all those qualities are not religious, but profane and earthly qualities, which we may find here on earth without taking the trouble of going up to heaven. Such qualifications are called by the scholars "anthropomorphistic," that is, where man over-estimates justice, he describes a just God, and where he has a liking for human flesh, he treats his God therewith. The advanced theologians are well aware of that and decline to give any description of their objects of worship. But is it not senseless to assert the existence of something and at the same time to confess complete ignorance of how, where and what its nature is? The more the idea of God recedes into the past the more palpable it is ; in olden times man knew everything about his God; the more modern the form of religion has become, the more confused and hazy are our religious ideas. The truth is that the historic development of religion tends to its gradual dissolution.

A little while ago I characterized religion as the substitute of human ignorance, that is, it fills up the gaps of knowledge. Where the gaps are wide, there the scope 
of religion is wide. The whole life of barbarian tribes, their work and their rest, their social customs and laws are under the strict control of God. The God of Abraham, Isaac and Jacob cares about the most insignificant details; he supervises the cleanliness of his people; he prescribes how to hitch their animals to the carriage, in short, there is nothing left to a true Israelite which is not regulated by divine command. The same may be said of all Asiatic religions. On the other hand, the civilized nations of to-day leave to God those things only whose laws have not yet been discovered, as the making of the weather, the healing of malignant diseases, etc. To an enlightened liberal the blessed name of the Lord is in reality no more than the $\mathrm{A}$, the beginning of the alphabet of his conception of the world. Once he passes beyond the beginning, he allows the world to take its natural course. To this un-Christian Christian everything in the world is natural except the beginning, which is unnatural and divine. It is this consideration which stands in the way of his giving up the belief in the existence of God, which has also the advantage of keeping the lower orders, the "illiterate," in check. The only link which connects this sham-religion of the Progressive-Liberal with the Catechism is the so-called " moral world." But inasmuch as he begins dimly to perceive that morality, too, has a worldly basis, his association of ideas becomes dim and shadowy. As soon as we are conscious of the fact that the ethical had not its roots in the divine will, but, on the contrary, that which, for social reasons, had become ethical receives subsequently divine sanction;- as soon as we recognize that ethics was antecedent to the "Eternal," the Church loses the ground from under its feet. If we compare the wide scope of religious life of the pagan past, when the trees and bushes, the hills and waters 
teemed with gods and goddesses;- if we compare the intense faith of early Christianity with its manifold saints and miracles;- if we compare all that with the position of to-day, when religion is pushed into the background by so many other considerations, then, I think, no impartial observer will be able to disagree with our proposition, that the progress or development of religion consists in its gradual dissolution. No doubt, this is the usual course of things in the world. With the first day of his life the new-born begins his pilgrimage towards the grave. And stronger words than those I could not conscientiously utter against religion. It is not an eternal or heavenly affair, but an earthly and temporal one.

The last and strongest religious argument, brought forward by rather unprejudiced minds, is the undeniable fitness of things in nature or in the universe. Who could deny the wonderful order of the universe, its harmony, organization and system? Apart from the numberless illustrations usually brought in favor of that argument, apart from the green, blue and speckled cuckoo's eggs, which, according to color and volume, always fit in with the bird's eggs to which they are added, we find in every step the proofs of a universal intelligence which uses everything that is living and existing as a part, as a suitable organic part of the whole. To recognize the evolution or the gradual organization, not only of nature but also of human society, is the special task of social-democrats. Their superior understanding consists just in this, that they regard all phenomena of nature and human history as being parts of the whole that are involved in the process of evolution, and even such things as religion, morality and property, which are usually looked upon as constant and eternal; there is no sacred exception to this rule. And how could they fail to recognize that 
there is in this whole something of a higher life to which the individual parts are subordinated? But when recognizing this, there is no necessity of going back to religion and mysticism. Experience has so much sharpened our wits that we spotted the rocks on which human reason, in its efforts to get at the truth, has hitherto often suffered shipwreck. The learned marked them with the ponderous name: anthropomorphism. It is the manner of the unsophisticated, which is so difficult to get rid of, to measure and to interpret the external world by the gauge of their own individual life. Because man pursues his aims deliberately and consciously he substitutes a being in his own image, gifted with deliberative power and consciousness, as the architect of the system of nature. And even among intelligent people whose sense of criticism is so far developed as to shake all belief in a personal God, we find that they cannot do away with all philosophic mysticism; they take refuge either in a philosophy of the unconscious, which attributes will and conception to unconscious things, or to spiritualism and theosophy.

It cannot however be denied that there is in dead matter a living impluse towards a higher form of organization, and that, consequently, the material world is not dead, but living. Yet, it is necessary to keep in mind that we can only speak of its will and purpose in a relative and comparative sense. For the manifestation of the universal intelligence is but gradual. The higher the organization of matter the clearer the manifestation of the intelligence. We see it in the animal instinct in a limited degree of clearness and it attains to a pure expression in the cerebral function of man, i. e., in our consciousness. To attribute purpose, will and conception to low-organized matter is therefore as wrong as to call 
twilight day because of the limited degree of light the former possesses. And if I ventured a little while ago to make use of those terms it was but with the intention to discredit them and to show their relative meaning. To be sure, there is reason in the natural things. But for this it was possible for the homo sapiens to appear without divine assistance on the stage of history. Those who recognize reason, the source of all system and of all fitness of things, as a product of nature, cannot fail to admit the suitability inherent in nature. Yet, the spirit of man is the only spirit. This name cannot be given to the reason which we find in the orderly revolutions of the solar systems, or in the cuckoo's eggs, or in the construction of the bee's cell, or in the working of the ants, or in the head of apes, but solely to its highest manifestation, to the consciousness, to the cerebral function of man.

Our spirit is the highest spiritual being. But, my pious friends, that is, my attentive friends, we must not put it on the high pinnacle of a religious godhead. High and low means in our materialistic philosophy as much as more or less organized. The less autonomous the parts of a thing are, the more they function as organs, the more interdependent and closely connected they are, the more numerous and varied their natural communications and services, the higher is the thing in the hierarchy of nature. Our consciousness is the universal center, the universal means of communication. But it does not exist by itself, isolated in aristocratic aloofness like our Lord God, but it is in its good democratic way only a point of contact, a connection with all other things. Even before natural science mastered the art of differentiation and unification, the logic or the science of mind had discovered that there is but one species, namely, worldly things, while everything else is but a variety. 
The conscious and unconscious, the plants and animals, the good and bad, all diversity, all antagonisms of the world must be considered as diverse forms of one and the same being, which gradually merge into each other, carrying on a perpetual struggle for existence, and renewing and perfecting themselves through natural selection. Out of chaos arose cosmos, which gradually evolved reason-gifted man, whose pleasant duty it is to further the progress of our world, to remove its imperfections. His task can be best effected by studying and organizing its forces. Indeed, man has always been working at his task, but until now in an unconscious manner: when his intellectual and civilizing efforts had sufficiently accumulated to form a great generalization and a new social stage he rested for a time; those were epoch-making instances which found their visible expression in a new religious conception: the animal-worship of oriental nations, the Law of Israel, the Humanity of Christ, etc. But where man becomes conscious of his task, where he recognizes in himself the absolute organizer, there the place of the religious conception is taken by the anti-religious social-democracy.

\section{IV.- I.}

It is in reality a priestly nuisance to address my comrades from the height of the pulpit. Pulpit, Christianity and religion have often been made to serve so many crooked purposes that it is very unpleasant for an upright man to come in close touch with them. Yet, we must approach them closely in order to do away with those things altogether. If you want to put a brawler out of the temple you must first embrace him,- that's one of the sensible contradictions of life. 
It is not an unusual phenomenon in history to see how one thing is being transformed into another thing with the name remaining the same. To the inexperienced the changed new thing is easily represented as the familiar old one. Such is the case with pulpit, Christianity and religion. This is a conservative trick which causes much confusion in the minds of the people. Even among our comrades there are some who are thus caught. They say: Christ was the first socialist. Yet, Socialism and Christianity differ from each other as the day does from the night. To be sure, there are points of resemblance between them. But show me the thing to which no analogy could be found! What does totally differ? Day and night have this in common, that they are both portions of time. The devil and the archangel are both of the same nature, though one be black- and the other white-skinned, inasmuch as both of them do claim some kind of a skin. It is the fundamental faculty of our mind to bring all diversity under one general heading. Though Christianity and Socialism may have some points in common, it is none the less true that whoever mistakes Christ for a socialist is surely a dangerous muddlehead. In fact, our knowledge is one-sided when based only on what phenomena have in common. We must look also for their differentiation. Not what the Socialist has in common with the Christian, but what distinguishes and differentiates him from the Christian shall be the subject of our consideration.

Christianity was recently qualified as the religion of servility. This seems to me a very apt qualification.

Indeed, all religion is servile, but Christianity is the most servile of the servile. Let us take the next best Christian saying we meet with on the road. On my way there stands a cross with inscription: "Mercy, gra- 
cious Jesus! Holy Maria, pray for us." Here we have the inordinate humility of Christianity in all its wretchedness. For those who build all their hope on mercy are wretched creatures, indeed. 'Those who start out in life with the belief in an Almighty God, and prostrate themselves before the destinies and forces of nature, and in their piteous feeling of impotency moan for mercy, are anything but efficient members of modern society. When we see that modern Christians act differently, that they brave the storm and courageously face danger, that they actively strive to remove calamity, it is only because of their defection from Christianity. Though they continue to keep their name, their song-books and their anxieties, they are in their doings and dealings perfect anti-Christs. We non-religious social-democrats must be fully conscious of this position. We want to be consciously and deliberately, in theory and practice, the energetic opponents of that sheepish and godly humility.

Rooted in the flesh like an old Adam is that disastrous human disposition to perpetuate a thing which was only meant to serve certain conditions. Inertia and selfishness are joined together to hush up, to deny or to conciliate the contradiction between Christian contempt of worldly life and the joyful, strenuous activity which distinguishes the present generation. Christianity wants resignation, while modern life wants us to work with all our might for the satisfaction of our material needs. Confidence in God is the foremost Christian virtue, while self-confidence, the exact opposite, is necessary to achieve success. Those who dare to put into the mouth of Christianity the maxim: "Trust in God, but thou shalt not hide thy talents," by which they mean to convey that work was not an un-Christian thing, but, on the contrary, a Christian command, are preposterous sophists. Wo $\mathbf{k}$ 
in the Christian sense differs wholly from modern and real work. The Christian works for Heaven, crucifies his flesh and subdues his passion. And when he works for his daily bread, then it must only be for such an unkeep as to prolong his tribulations in this valley of tears in order to be worthy of true eternal life. "He that loveth his life shall lose it; and he that hateth his life in this world shall keep it unto life eternal" (St. John, I2, 25). Heavenly eternity is the aim of the Christian; the earthly world is the aim of sensible men.

Herr Daniel Schenkel, D.D., of Heidelberg, is indignant at the assertion that the essence of Christianity is the negation of this world. "Is it true," he exclaims, " that Christianity does not regard this world as a worthy place, nay, not even as a possible place for religion this world of which the Gospel says: So did God love $\mathrm{His}$ world that $\mathrm{He}$ sent His only begotten Son unto it. Did the primitive Christians renounce the world? Didn't they rather expect Christ to appear again on earth and to substitute a new order of things for the old, rotten one?" Thus speaks a sophistical reasoner who cares very little for consistent reasoning, but a good deal for a compromise between his half-hearted rationalism and the Christian religion. Or does he feel the need of deluding others, if not himself, too? Does he not know that Christianity has two worlds like the Prussians, one that is white and the other black? The beautiful world of reality the Christian has painted black. Its glories are but temptations of the devil; its labor a curse; its love a sinful lust; the flesh a weariness to the spirit; the body a wretched carcass. As the enchanted prince dwells in a wild beast so does the white world of Christian imagination live in this black reality. To save us from this world God has sent His Son, who leads us into 
the heavenly world of Christianity. It consists of spiritual matter, which is just as possible as iron wood-blocks. Its men and women are sexless; its bodies have no gravity ; its work is painless. To be sure, the primitive Christians did have the desire to renounce the world. They expected the reappearance of Jesus at any moment; they expected the destruction of the world and the crack of doom. "My kingdom is not of this world."

However, the fantastic salvation of Christianity, which aims at removing the toils of the world, not by energetic work, but by believing and trusting, could not possibly suppress forever the sensible desire for the enjoyment of material life. The heretics, reformers, Protestants, old-Catholics, Unitarians and high critics have all of them contributed to the victory of the blackened and libelled truth over the whitewashed lie of religious imagination. Insofar we Socialists are at one with the Progressives. But we protest against this cowardice in clinging to the old name and in trying to pass off their defection from faith for a restoration of true Christianity. It is necessary to discredit the name in order to do away with the thing itself.

The religion of the Capitalists is as equivocal and contradictory as their political economy, liberty, equality and fraternity. The farce of the renunciation of the world, played by the fat monk, is being continued by the wellfed bourgeois. And the most ludicrous part of it is that the Progressive falls a long way behind the monk, who at least was conscious of the austere character of religion. The lukewarm and insipid Christianity of the modern humbugs claims to be the only genuine article. The old leaders of Christianity, the Saints of the Calendar, manifested a real contempt for the world and its pleasures; they loved the life of a hermit, wore the hair shirt, morti- 
fied their body and fed themselves on roots and herbs. Their life bore evidence of their doctrine: "God is a spirit." Our modern crusaders turn to another page where it is written: "He was made flesh and dwelled among us." No doubt, the germ of equivocation and senseless contradiction lay from the beginning in the Christian doctrines. The apostles and church fathers made sometimes concessions to the public. They taught how to drive out lust by marriage, and Satan by Beelzebub. From some passages it might appear that praying and fasting were the highest Christian duties, while from other passages the opposite conclusion might be drawn, that the Lord finds no pleasure in sacrifice. Christianity, not being above nature, cannot dispense with the joy of life altogether, and must end by compromising and trimming. The clear-sighted social-democrat will not be detained by the trees from recognizing the forest. The essence of Christianity is abstemiousness in this world and sweet peas in Heaven.

A doctrine which swayed nations and continents for centuries has surely its historic significance. But this granted, we must reject its claim to eternal domination. The good which Christianity contains, as, for instance, mortifying the flesh as a means against non-married lust, or brotherhood of man against national jealousies, is readily accepted by social-democracy. We condemn all jingoism which, however, the Christian church as a rule fosters. Yet we cannot regard that truth as divine and holy.

With that difference between religious and secular truth we arrive at the point which essentially distinguishes the Socialist from the Christian. To its elucidation I should like to ask you, my friends, to give me your special attention for a while. 
Truth is truth, undoubtedly! But in its religious form it is one-sided, insensate and intolerant. Take for instance the principle of brotherhood of man. It is an eternal truth, i. e., it is a human need that men shall live together. Sociability is in their nature, they must love one another; and where they fail to recognize it they suffer in their own well-being and happiness. Where, however, the religious believer has taken up that principle, where the Christian commands : Love thy neighbor as thyself, there he goes at it with such a fierceness that he knocks all rime and reason out of it. When he be smitten on the right cheek he is to offer the left one, too. When he preaches love he excludes hatred. On the other hand, Socialism does not only preach love of humanity, but is based on it. The anti-religious, reasonable love of humanity knows how to limit itself; it does not overshoot the mark or exclude its antithesis: the hatred, but includes it as a holy because necessary means for temporary use. We, too, desire to love the enemy and to do good to him who hates us - but not ere we have effected his unconditional surrender. Meanwhile we sing with Herwegh:

Die Liebe kann erlösen nicht,

Die Liebe nicht erretten, Halt du, O Hass, dein jungst Gericht, Brich du, O Hass, die Ketten.

Bis unsre Hand in Asche stiebt, Soll sie vom Schwert nicht lassen, Wir haben lang genug geliebt

Und wollen endlich hassen.

(Love cannot save, Love cannot redeem, Arise thou, $\mathrm{O}$ Hate, and break our chains.

Until our hand withers we shall not relinquish the sword, We've loved long enough, let us now hate.) 


\section{IV.-2.}

The question we are dealing with concerns the difference between religious and profane truth. That the Jew shall not run about unwashed, Moses prescribed cleanliness as a law. Cleanliness is a necessary requirement; it is a truism. In its religious form however it is of a solemn immobility, fixed to time, place and number; it prescribes when, in what manner and how often one must wash. The religious truth is a binding prescription; secular science and the free use of water cleanses more thoroughly than that prescription. In science the atom is as worthy an object as the starry sky. There is no fixed gulf in science between worthy and unworthy objects, and none in scientific ethics between good and evil. All things and qualities are useful and suitable; clean and unclean, love and hate, enjoyment and renunciation - all is relative, more or less, according to time and conditions. Scientific freedom, subordinating all things and qualities to human ends, is thoroughly antireligious. Religious truth consists just in this, that it lifts natural qualities above nature, that it separates them from the living stream of human progress and confines them in a stagnant pool.

In qualifying the common and profane truth as "scientific," I should like to remind you, friends and comrades, that the scientific truth is called profane and common. It is necessary to bear that in mind, seeing that a scientific priesthood has arisen which is aiding and abetting religious priestcraft. To destroy palpable superstition would be an easy matter if dualistic confusion were not on the lookout for the gaps of science in order to lay there its eggs. Such gaps are to be found especially in the field concerning epistemology, the theory of the 
method of cognition. As the Laplander or Firelander is terrorized by mighty natural phenomena, so is the professor by the wondrous working of the human mind. Enlightened freethinkers, who easily dispense with Christianity and religion in general, are still caught in the snares and pitfalls of superstition as long as they don't clearly distinguish between religious and profane truth, and as long as they are not clear about the organ of truth or the faculty of knowledge. Having materialized everything spiritual, there remained nothing for the professors but to spiritualize their own profession, science. They assume academic knowledge to be of a different stuff from, say, the knowledge of the peasant, of the dyer or of the smith. Scientific agriculture is, however, only insofar ahead of usual farming that its rules or its knowledge of the so-called natural laws are generalizations of a more comprehensive kind. They but differ from each other in degree and not in essence, as for instance a quart of legumes from a quart of peas. There must be no groping in the dark about the insipid difference between noble science and common understanding, if we want to overcome the claims of the aristocracy of intellect. Our opponents may indignantly protest against such crude notions of the democratic levellers who even refuse to recognize intellectual distinction. Yet, quite as the old struggle against aristocracy was not meant to disparage their glorious ancestors, so our shafts are not directed against the intellect of the intellectuals. We object only to the material privileges which the knightly highwaymen and academic scribblers lay claim to. Since it is no more possible to brutally coerce the people to the production of wealth, the learned satellites of our rulers cheat them with the miracles of intellectual labor. The distinguished and lucrative position of the professor 
as well as the profits of the employer are defended under the false pretences that intellectual labor stands far higher and is ten times more productive than manual labor. Because we social-democrats are treating such presumptions with contempt, we are nicknamed "blasphemers of art and science." We have the deepest contempt for the stilted phraseology of "culture and science" and for the talk of the graduated flunkeys who, like the pagan priests with their rudimentary knowledge of nature, use their sham idealism to keep the people in ignorance. The modern dualistic belief in the world of a scientific and of an ethical spirit, which is supposed to be superior to the common world and is therefore to control it, is nothing more than the rehashed superstition of an earthly and heavenly life. Professors who need the support of religion transform the Kingdom of God to a kingdom of scientific spirit. As Lord God finds his antipode in the devil so has the pious professor his antagonist in the materialist.

The materialistic conception of the world is just as old as the religious disbelief. And both have been worked up in the nineteenth century from their crude form to scientific precision. But our learned academicians fail to understand that, because they feel their social position endangered by the democratic tendencies inherent in materialism. Feuerbach says: "It is the characteristic feature of a professor of philosophy not to be a philosopher, and conversely, it is the characteristic feature of a philosopher not to be a professor of philosophy." To-day we are a step farther. Not only philosophy but science in general has left its official mouthpieces behind. Even where there are materialistic professors in the professional chair, there adheres to them some unscientific religious nuisance in the form of an idealistic remnant as 
pieces of egg-shell to the unfledged bird. Furthermore, one swallow makes no summer, and the really scientific conception of a professor cannot take off the blot which sullies his whole class. As long as the middle classes and their leaders had to fulfill a civilizing mission, their academies were nurseries of learning. Since then, however, history has moved forward, and the struggle for a higher civilization has been devolved on the working class, the nethermost stratum of human society. Despite this historic change the old decaying rulers are making great efforts to preserve their power and are looking to the academic dignitaries for support, thus turning the "free scientists" into well-paid attorneys to defend a dying cause.

The socialist demand for a more equitable and popular distribution of economic goods can be realized by a democracy only, by a government of the people who do not tolerate the rule of a clique which, under the pretence of intellectual superiority, seeks to appropriate the lion's share of the social wealth. In order to keep that presumptuous selfishness within reasonable bounds it is necessary to understand clearly the relation between mind and matter. Philosophy is therefore a subject which closely concerns the working class. This, of course, does by no means imply that every working man should try to become acquainted with philosophy and study the relation between idea and matter. From the fact that we all eat bread does not follow that we must understand milling and baking. But just as we need millers and bakers so does the working class stand in need of keen scholars who can follow up the tortuous ways of the false priests and lay bare the inanity of their tricks. Manual laborers do not sufficiently appreciate the real value of mental labor. Their healthy distrust against the leading scrib- 
blers of bourgeois society leads them too far. They see how much wrong-doing is going on under the cloak of intellectual work and are therefore inclined to undervalue mental labor and to overestimate manual labor. This brutal materialism must be counteracted. Physical vigor, bodily superiority was always the prerogative of the working classes. But in default of mental training they have so far been outwitted. The emancipation of the working classes requires that they should lay hold on the science of the century. The mere sentiment of indignation against the unjust conditions under which we suffer does not meet the case of freeing the working class, superior in numbers and physique as they may be. They must have recourse to the armory of intellect. Of all its weapons the theory of cognition or the theory of science, that is, the understanding of the scientific method of thinking, is the universal weapon against religious belief, driving it out of its last hidden recess.

The belief in Gods and demi-Gods, in Moses and the Prophets, the belief in the Pope, in the Bible, in the Kaiser, in his Bismarck and his government, in short, all belief in authorities, finds its definite and final reply in the science of mind. As long as we have not discovered how and where wisdom arises we are easily exposed to the danger of being bamboozled. The clear knowledge of how thoughts are being produced puts us on a coign of vantage which makes us independent of God, books and men. In dissolving the dualism of mind and matter, the theory of the scientific method of thinking destroys the last pillar which supports a society divided into rulers and ruled, into oppressors and oppressed.

I don't think here is the proper place to enter more fully into the discussion of the theory of mind. I shall confine myself to the statement of some of its most evi- 
dent and irrefutable propositions, in order to be able to oppose the presumption of the ruling classes which, by pleading intellectual work, endeavor to extenuate the charge of their exploitation of the people. The socialist attack on their economic, or class, position fills them with fanatic fury. They are therefore unable to bring the necessary impartiality to bear upon the study of subjects which may produce social changes. Mental and social science can hardly meet with the sympathy of an audience which, through their privileged and propertied position, are interested in clogging the wheel of civilization. Such a science appeals all the more to the judicious attitude of the have-nots, of the disinherited and oppressed.

Ad rem! Spirit is neither a ghost nor the breath of God. Idealists and materialists agree that spirit belongs to the category of "worldly things," dwells in human brains, and is nothing else than an abstract expression, a collective noun expressive of thoughts which exist simultaneously and follow each other in organic order. If spirit is understood to be no more than another word for our force of thinking, who could then deny the somewhat paradoxical, yet empirical, proposition that mental work is a bodily effort? With this I venture to introduce you to the rather difficult chapter of contradictions. As line and point are but mathematical conceptions, so are contradictions no real things, but logical niceties, and have only a relative and comparative value. Relatively the great is small and the small great. In this sense we may say matter and mind, like all opposites, are logically but not really in opposition to each other, since all opposites are such only in way of comparison. Our body is so closely connected with our spirit, that physical labor is absolutely impossible without spiritual collaboration. Even the simplest work of an unskilled laborer requires 
the co-operation of mind. Conversely, the belief in metaphysics or in disembodied spiritual labor is an absurdity. Even the purest mental exercise is undoubtedly an effort of the body. All human work is both mental and physical. From my preceding lectures at least as much is evident, that thoughts not only originate from the brains and therefore proceed subjectively from matter, but that they always and everywhere have some palpable thing as their object. Cerebral matter is the subject of thought, the infinite material of the world is its object.

The mind as well as the body is eager to produce, to bring forth fruit. Therefore intellectual work must become materialized and bodily work spiritualized. An analysis of the product of labor will never indicate how much the mind has contributed to it and how much the body, for they operate together in close companionship, and not in isolation from each other. A certain work may be characterized, either as mental or physical, the product however, is made both by mind and body. Their contribution to the whole cannot be separated. Who could indicate in a kitchen-garden what parts of the plants are due to the spade, the arm of the gardener, the soil, the rain and the manure? It has always seemed to me an idle and poor endeavor to divide up the products of labor according to the factors which contributed to them. It is a perverse bourgeois idea which cannot be consummated and leads, moreover, in practice to just the opposite result. This idea appears to be the outcome of that cardinal perversion which wants to turn man into an independent producer who, freed from all social trammels, should compete with his fellow individuals and thus realize the fantastic ideals of personal liberty. But you, my friends, know full well, that all 
work in the capitalist world is in reality performed in common. The intellect of the journalist works for the manufacturers, and the manufacturers produce linen for the journalists, police agents, shoe-polishers, etc. One for all. Nobody looks for his ultimate object in his own product, everybody aims at the products of all which are supplied by the world's market and find their realization in the form of money. If we judge the performance of each member of our society according to the money he receives, then the stockholders must have contributed an enormous amount of social labor.

The work of the individual and that of the family, the work of the factory and that of the whole society, is an organism, each part of which contributes to the whole. The contribution of each organ cannot be mechanically weighed or measured. The Socialist is quite aware that the workers are organs of the work process. $\mathrm{He}$ has completely given up the insipid idea of individualizing and dividing up a communistic product, and paying to each according to his deserts. Present society, with its misunderstood principle of suum cuique (each unto his own) and its grotesque justice, acts as unreasonably as the man who gives his eye an overweening care while utterly neglecting his leg. As the engineer is more careful about his smallest screws than about his big wheel, so do we desire that the product of social labor shall be divided according to the social needs, so that the strong and the weak, the swift and the clumsy, the mental and the physical labor, insofar as they are human, shall work and enjoy in human community.

That object, my comrades, is opposed by religion.

And not only by the formal, the common religion of priestcraft, but also by the most purified and sublime professional religion of hazy idealists. Since the 
publication of the first part of my sermon, I have been taken to task by several people that I was carried away too far by my criticism. Our friend Schäfer of Francfort thinks that I was condemning Jesus for the misunderstanding of his followers. They had made of His teachings what the Master had never intended; we should therefore discriminate between the ideal true Christianity and the degenerated one. My criticism against the inordinate Christian humility was not well-founded, for the Lord Himself was courageous enough to chase the money-lenders out of the temple.

To that I should like to reply: Christianity aims at the divine control of the world. What a vain endeavor! Christianity itself is being controlled against its will and desire by the nature of things. "Therefore it is so full of compromises," therefore the apostle, with all his desire for celibacy, must allow marriage, and therefore Christian non-resistance, which commands to tender the left cheek when the right one was smitten, is swept away by the indignation of the smitten. But, you see, it is not the consistency, it is, indeed, the inconsistency of Christianity, for it lays special stress on the necessity of absolute resignation, on the patience of the lamb carried to the shambles. Such humility has surely its limits, but that a revolutionary upheaval was a part of the divine mission is beyond doubt quite foreign to the spirit of Christianity, though we might find here and there an insignificant instance from which the contrary might be inferred. Whether Christ really meant or wanted such a humbleness, I cannot say. After all, why should such a question have any interest for us? Profane and true truth is not based upon personalities. It is based on external objects; it is objective. It does not lay claim to validity because it originates from a great 
master. The utmost we can say is that the master took hold of it because it was valid. And just in this lies the mistake and the superstition, of which our friend Schäfer is guilty and which makes me indignantly knock at the pulpit that people are full of hero-worship and cannot give up their belief in authority and their idolatry of the great spirit.

Great men, who carry forward the beacon of knowledge, surely deserve all honor, but only insofar and as long as their teaching is founded on realities.

\section{V.}

Love for the preceptorial office and for the prominence of the pulpit as well as the approval of a friendly and indulgent audience induce me to continue my sermons. It is, however, but fair to mention that there are a good many among you who blame me for being too "scholarly" or not "popular" enough. To that I reply that only trite sayings and truisms are easily comprehensible. The so-called popular things always move in the old ruts, while social-democracy has a new doctrine, based on principles which are generally misunderstood and require a total transformation of our mode of thinking, and therefore cannot be comprehended without a certain mental effort.

Religion, my comrades, is primitive philosophy. On the other hand, Social-democracy is a still growing product of the whole historic past. We are, therefore, justified in substituting historically developed, worldly, Science for Religion and do not deviate from our subject by dwelling on worldly, non-religious, matter in these hours of devotion. I called religion philosophy because it claims not only to redeem us, with the help of Gods, 
and by praying and whining, from the earthly miseries, but also to lend a systematic frame to our thinking. The universal significance of religion for uncultured tribes is founded on the universal need for a systematic knowledge of the world. Just as we generally have a practical need for the dominion over the things of the world, so do we generally have a theoretical need for a systematic view of life. We require to see the beginning and the end of everything. The insipid clamor about the universality, eternity and inevitability of religion is not without some justification. To flatly deny it would be Russian nihilism which was justly expelled from the "International." 1 We are far from senseless negation. We scorn the "Kulturkämpfer," in order to fight for real culture. We acknowledge that the need for a systematic view of the world is inherent in man who always requires a canon for his thoughts and deeds. The things which engage his attention, as for instance mind and body, the transient and the lasting, time and eternity, reality and appearance, ethics, state and society, he wants to see in a certain order and logical sequence. Man requires to have a reasonable connection of his ideas, so that he may bring a reasonable system into practical life. We, too, we social-democrats and defenders of revolutionary movements, feel the same want. Servile trimmers and bunglers may perhaps on that ground think us religious. We reject that qualification. Not because we refuse to admit that religious and social-democratic philosophy have something in common, but because we want to emphasize the difference between them and to break away not only internally, but

\footnotetext{
An allusion to the expulsion of Bakounin from the "Internationai" in 1872.- EpITor.
} 
externally also, in name and deed, in short completely from everything which smacks of priestcraft.

Yet, it is not sufficient to dethrone the fantastic and religious system of life; it is necessary to put a new system, a rational one, in its stead. And that, my friends, only the socialists can accomplish. Or, if the doctors of philosophy think this language too presumptuous, I will put it differently, though the meaning remains the same: our social-democracy is the necessary outcome of a non-religious and sober way of thinking. It is the outcome of philosophic science. Philosophers wrestled with the priests in order to replace a non-civilized mode of thinking by a civilized one, to replace faith by science. The object is achieved, the victory is won. Cannibal religion of primitive ages was softened by Christianity, philosophy continued in its civilizing mission, and after many untenable and transient systems produced the imperishable system of science, the system of democratic (dialectic) materialism.

The Prussian professor Treitschke thinks the selfconfidence of social-democracy to be a clever trick used with the purpose of imposing upon the people. Of course, he looks for us behind that hedge where he is sheltering himself. The professional sycophants, the prostitutes of the pen, having long ago sold their honor, are quite unable to grasp either the convincing power of truth or the self-confidence inspired by a consistent and systematic view of the world. The socialist philosophy, with which we are dealing, is a closely serried and well-knit system. A thorough treatment of it could only be carried out from a professional chair specially appointed for that purpose. My task is a different one. In the first place I want to interest you in the new philosophy and to stimulate you to further investigation and 
thinking for yourselves. I am to-day more of a raconteur who does not begin with the beginning nor finish with the end, but by a rambling method wants to excite the curiosity of his audience. I am giving you the outlines and the salient points only, which you should fill up and further develop by your own work.

We call ourselves materialists. Just as religion is a generic term for various beliefs, so is materialism a general name for various scientific conceptions. Reviewing the world from the lofty standpoint of the religious heaven, everything - even the purest ether appears to be common matter, dirt and clay. All philosophy, even idealist Platonism, all scientific investigation, all positive knowledge is in the distorted eyes of religion no more than material aspiration. Indeed, all philosophers are materialists in disguise, for all of them want real knowledge, knowledge of real truth. Materialists in the contemptible sense of the word, who find the whole object of life in eating, drinking and in the satisfaction of physical wants - simple philistines have no room in science, they form no particular school and do no theorizing whatever. Philosophic materialists, on the other hand, are those thinkers who put the real world at the beginning, at the head of their investigation, and the idea or spirit as the sequel and outcome, as the product, while their opponents follow the opposite method: they decree, after the religious method, the rise of reality from the logos (God spake and it was), the material world from the idea. No doubt, materialism suffered heretofore from the lack of sound logical evidence. But now we social-democrats accept the name, with which our opponents think to abuse us, because we know that "the stone which the builders refused is become the head stone of the corner." We would be 
equally justified to call ourselves idealists, inasmuch as our system is based on the final results of philosophy, on the scientific investigation of ideas, on the clear insight won into the nature of mind. How little our opponents are capable of understanding us is shown by the contradictory names given us. One time we are called crude materialists whose only desire is to lay hold of the wealth of the rich, and another time, when dealing with our communistic ideals, we are called inveterate idealists. As a matter of fact we are both materialists and idealists at the same time. Palpable, true reality is our ideal, the ideal of social-democracy is material.

The "Alphabet of Knowledge for the Thinking," published lately in the Volksstaat, designated the inductive method as the "impregnable basis of all science, which builds on facts." The application of this method to all problems of the world, that is the systematic application of induction shapes the socialist conception of the world into a system. Its categorical imperative is as follows: "Thou shalt not begin to speculate without material; thou shalt base thy deductions, rules and axioms on facts only, on palpable realities. Thinking must begin with data." We begin to speculate, but we don't speculate about the beginning. We know once for all, that all thinking must begin with some fragment of a real phenomenon, with a given beginning; the inquiry into the beginning of the beginning is therefore a nonsense, contradictory to the general law of logic. Those who speak of the beginning of the world imply that time was antecedent to the world. "Nothing was" are two words which preclude each other. That something was which was not, can only be asserted by a shrewd idiot who draws square circles. Nothing can only mean: not this nor that. Our philosophic system begins with the 
knowledge that beginning and end are, if I may say so, subjective modes, or categories, of the human mind.

And as logical as the beginning is our sequence. The whole metaphysics, which Kant sums up as the question after God, free will and immortality, finds its final solution in our system, through our knowledge that understanding and reason is an absolutely inductive faculty. That is, our comprehension of the world is perfect when we arrange and divide the empirical things according to their general qualities in species, classes, conceptions, etc. This is quite a truism which would hardly be worth discussing but for the superstitious and ideologues who are never tired of jabbering about deduction. They assert that our intellect possesses still a second method in ascertaining the truth, though simple, palpable truth is inductive. But they claim that in mathematics for instance, the deductive method is supreme and independent of experience. Knowing that two and two equals four we also KNOW that the same result would be obtained in heaven and on earth and always and everywhere. Insofar we also know of times and dimensions which no human eye ever perceived and no human ear ever heard. That a camel has two humps was a simple experience, but that two and two equal four, or that the part is smaller than the whole is claimed to be a transcendental, metaphysical truth, a deduction from pure reason. They believe, so to speak, in an inner light which revealed them the mysteries of mathematics, ethics, the existence of God, the immortality of the soul, freedom of will and other transcendental moonshine. Thanks to the idealistic studies of a Descartes, Spinoza, Leibnitz, Kant, Fichte, Hegel we were able to advance to our materialistic philosophy, to reveal the deductive ghost of the transcendentalists. The celebrities of phil- 
osophy have one after another so far promoted and strengthened the cause of truth that we social-democrats, standing on their shoulders, are able to understand completely the mechanical nature of all knowledge of the religions, the speculative as well as the mathematical. It may sound strange that that knowledge is due to our party standpoint, considering that a scientific result is a human affair. Yet, our assertion is easily comprehensible, for social-democracy does not represent a party, but humanity. The party of the disinherited is the party of the disinterested, is the party of impartial truth. We social-democrats have the easiest access to philosophy, for our mind is not dimmed by narrow selfishness.

The transcendental certainty, the deduction which is to be found in the proposition that two and two equal four, is, like any other deduction, a mere subterfuge; four and two times two are but different terms for one and the same thing. Everything has a certain substance. Smaller parts form the substance of the whole; handle and blade form the substance of a knife; two mountains have a dale between, and in the number four is contained two times two. Thus, because the substance is quite mechanically given in a thing, we are apodictically certain and transcendentally convinced that two times two equal four, the part is smaller than the whole, the knife is not without a handle and a blade, and two mountains are not without a valley. Where only the wet is called water, there we don't need any special transcendental faculty to know categorically that water must be wet. No special light is necessary to attain to the understanding that deduction, like any other profane knowledge, is based in the last resort on empirical facts. Yet, after all inquiries into facts, and after 
all understanding of their bearing, they are not a whit less miraculous than before. So, for instance, we know that grape-juice turns almost overnight into an intoxicating liquor. How is that to be comprehended? The chemist will tell you: "It is fermentation. Grape-sugar, exposed to the influence of heat and air, turns into alcohol." Thus the incomprehensible is explained, the production of wine is a chemical process belonging to the general class of fermentation. Facts are comprehended by ranging and classifying them into a certain system, and not by dissolving them into logical alcohol. Philosophic mysticism is an undigested remnant of the theological period. In order to dispose of both of them in a radical manner it is necessary to be imbued with the knowledge that facts do not rest on logical grounds, but conversely that the fundamental basis of all logic is ever the fact, the being, the external reality.

I must apologize, my friends, for troubling you with such hair-splitting dissertations. I am quite aware that there are but few among us who care for such discussions, but the few are just sufficient for our purpose. It is necessary that some of us should be able to face official philosophy. We must lay bare the foundation of zur theory in order that the sight of its granitic rock shall demonstrate in a striking manner to the impartial observer how shifty the sands are on which the braggarts of the existing order have piled up their contradictions. They reason without any system, without any logic or consistency. They have advanced the proposition that everything must have a cause, a beginning and an end. But how do they demonstrate it? They demonstrate it with the belief in a God who has no beginning, and in a life which has no end. The same lack of consistency is to be found in the politics of the existing order. One 
of its organic laws promises freedom of public meeting and speech; but where the people make use of that freedom and come together to express their sentiments and thoughts, there the policeman is set on them. Is this system, logic or consistency? $O$, yes! It is the system of infamy. All the deeds and thoughts of our rulers are concentrated in the logical idea: We are at the top and we mean to stay there for good.

\section{VI.}

Our last considerations were devoted to the traditional saying: "Man needs religion," which we ventured to translate into reasonable language by declaring: "Man needs system." It is his intellectual need to gain a safe standpoint from which he could survey the world. In order not to go astray in the midst of the bewildering multitude of phenomena, man divides the heavens into constellations of stars, the cosmos into regions, and likewise our earth into classes, species, families and individuals. In short, he gives diversity diversified names. To have system implies the ability of finding one's way and of classifying things. That an animal is the subject of zoology, and a plant the subject of botany is easily grasped, but it is by no means so easy to tell the branch of knowledge where such notions as truth, freedom, justice, etc., belong to. No system is perfect unless it has found a place for every phenomenon, has classified everything and has made provisions for everything. Founders of religion as well as philosophers attempted to make such systems, but none has stood the test. The stream of time has brought and is still bringing to light new phenomena, new experiences, new things for which no provision was made. They don't fit into the prevailing system, and therefore a new one 
was necessary, until social-democracy was wise enough to construct a system of thought sufficiently comprehensive for all present and future phenomena.

This is apparently an overweening assertion. In order to justify it I must somewhat retrace the steps we have taken until now. As the theologians look for a God who unites in his personality the omnipotence of the world, so the philosophers have been searching for a system which concentrates all knowledge in a single knot, so as to swallow all science in one bite. We know, however, that a color cannot be green and blue and yellow and black at the same time; that is, that the whole species cannot be incorporated in one individual. All science cannot be concentrated in a single human being and still less in a single conception. Yet, I ventured to assert that we possess such a concentration. Or does not the conception of matter contain all materials of the world?

So, too, has all science one general form in common, namely the inductive method. That the induction is the only general form of science, and that induction can be applied to all problems, to all objects - this conviction lends to social-democracy its systematic steadiness, its mental superiority, which astonish our opponents. We do not know everything, but we know the general form of all science and use it as a touchstone to find out all the tricks played against the people by the henchmen of our rulers. In natural science the inductive method is wellknown, but that there is in it a systematic philosophy which is destined to put an end to all religious, philosophical and political humbug, this is a social-democratic novelty and acquisition.

Our opponents, the rulers and the rich, the progressives, liberals and free-masons are also advocates of induction 
- but only insofar as it suits their purpose. They divide everything: the people into masters and servants; life into an earthly and heavenly one; the person into body and soul; and science into induction and deduction.

Now, dividing and classifying cannot be objected to, provided that there is system, that the divided parts are kept under one heading, and that the diversity is known to be but a gradual one. It is not unreasonable to divide life into an earthly and a spiritual one, but when so doing we must be conscious that both are forms of the selfsame life, and that both are of equal value. Social-democrats, too, have a body and a soul. Our body is the sum total of our corporeal qualities, and our soul is the sum total of our mental qualities. Yet, we must always remember that the empirical phenomenon comprises all matters uniformly, and that it is the common term for flesh and soul, for body and spirit. Soul or spirit is in our opinion an attribute of the world and not, as the priest asserts to the contrary, the world the attribute or the handiwork of the spirit. Darwin teaches the descent of man from animal. He, too, differentiates man from animal, but only as two products of the same material, as two varieties of the same species, as two sequences in the same system. A systematic and consistent classification of this kind, as well as the cosmic unity is unknown to our opponents. In this respect the good old religious life must be commended. It had at least a certain system. Earthly and heavenly life, lordship and slavery, faith and knowledge, were all under the united and centralized government of Him who said: "I am the Lord, thy God."

I know quite well, that the believers, too, have a dualism and are guilty of a relative lack of system. I am quite aware that they are fluttering between heaven and 
earth. However, before the liberal wedge of doubt had entered the religious flesh, when religion was a more serious affair, it was also less dualistic. The devil was but a tool, the earthly life but a transitional term of probation for the eternal life. One was subordinated to the other. There was a center of gravity and a system. In comparison with modern half-heartedness and freemasonry, religion did encompass the whole in a monistic manner.

This consistent encompassing of the whole, my dear friends, is a difficult problem with which the human mind has grappled since it began working. The nineteenth century has solved the problem and given philosophy a system. If in spite of all the light and leading of our thinkers and scientists, people are still groping in the dark, it must be due to political reasons. $\mathrm{Re}$ actionary ill-will has scented the revolutionary consequences of the inductive method. Hegel himself was already cautious enough to put his light under the bushel. And his more courageous followers could not make headway at a time when conservative vileness governed supreme. Even to this day the privileged classes are doing their utmost to keep the smouldering embers well under the ashes. Comrades, let us fan tham into flames. When they are aglow all the children of the night will disappear.

The stomach can't go on without food and Arink, nor the head without a system, that is, without a connected view of life, a "final cause" from which everything proceeds. This final cause is rather a ticklish thing.

According to the religious systems God is the final cause. Liberal ideologues believe it possible to base everything on reason. Prejudiced materialists find in hidden atoms the final cause of the universe, while social- 
democrats demonstrate everything by induction. We hold to induction on principle, that is we know that knowledge cannot be got by deduction, by drawing from pure reason, but that it is gained through the instrumentality of reason from experience.

That logical method is already known to other people, but they lack the systematic knowledge of it, they lack consistency. The philosophy of the anti-socialists is not homogeneous; it is rather a mixture of induction and deduction. They know how to induce, but they don't know the system of induction. They are well acquainted with details, but they utterly fail when dealing with the general aspect of the world. They can readily find the beginning and end of a certain thing, they can tell in concrete cases which is sham and which reality. But when confronted with the question of the general beginning or of the general relation of truth, justice, energy, matter, unity and multiplicity, cause and effect - they are at their wits' end and the rearing of the Tower of Babel begins. Some quote the Revelation, others take refuge in Kant or in some other venerable classic, still others forsake theology and philosophy altogether and apply themselves to scientific experiments and expect the solution of the problem from natural science.

In the face of such a helpless muddle international social-democracy is proud to know the "final cause" on which everything rests, and to possess a scientific basis for everything, and a systematic philosophy. Our decided superiority of principle is clearly manifested by the unanimity of our aspirations and demands, while our opponents are hopelessly divided on all questions of religion and politics. To be sure, there are differences of opinion in our ranks too, yet the anti-socialists have no reason 
whatsoever to rail at the dissensions among the socialdemocrats. We quarrel about detail, about forms of organizations, about practical and tactical questions, but in general principles and in matters of theory we stand as a solid and united phalanx, shoulder to shoulder, for we have what the Old- and New-Catholics, Protestants and Freethinkers would like to have: we have system. The beginning and end of all philosophy is clear to us.

Of course, comrades, this does not mean that every social-democrat possesses a full knowledge of the system. 'Not all of us have received a systematic training, else there would be no need for my preaching. What I ventured to assert is that your social-democratic aspirations proceed from systematic science. I assert that the inductive demonstration of a thing is the only, true, scientific demonstration, and that a consistent application of induction yields very remarkable anti-religious and revolutionary results. I should very much like to enter into details illustrating my assertion, but I must for the present abstain from that in order to first consolidate the foundation of our philosophy.

I repeat, and as a preacher who is anxious to drive home his teaching I am entitled to repeat: In the place of religion social-democracy puts a systematic conception of the universe.

This philosophy finds its "final cause" in the real conditions. The philosophy of the Liberals acts in the same way in natural science and in business only, while in matters of human society it looks for the final cause in the revelations of reason, instead of religion. They want their notions of justice, truth and liberty to be the models for an equitable, true and free society. The fact that feudal as well as liberal and clerical ideals of justice, freedom, political truth and wisdom have been moulded 
after the material interests of those respective parties, could not fail to teach us that ideals do not spring from the human head, but are formed by the human head from empirical materials.

Therefore we are able to mould consciously and with systematic consistency our notions of justice and liberty after our material needs, that is the needs of the proletariat, of the masses. The real bodily need and the present possibility of a "life worth living" is the "final cause" from which spring the equity, truth and rationality of the social-democratic demands. In the system of induction the body precedes the spirit and the fact the notion.

The frequent use of one and the same word having a soporific effect on the mind, I shall for a change call our system "The System of Experimental Truth." The dawdlers of the bourgeois parties talk a good deal of divine, moral, logical, etc., truths. We, however, know of no divine truth, we but know the empirical truth. We may divide it into parts and give them special names, but its general character will remain. Truths, no matter how we call them, are based on physical, corporeal, material experience. As such they are but parts or classes of the experimental system. We cut only from one, from one whole. We demonstrate our propositions empirically and really, and our procedure is systematic and logical. Could there be, my friends, anything more evident than such evidence?

Having laid bare the foundation we proceed to look at the structure of our universal system from the most elevated point of vantage. We see the infinite diversity of things to consist of the same homogeneous, empirical material. All diverse qualities possess one general quality. How different they may be, big or small, ponderable 
or imponderable, spiritual or physical, all things of the world have this in common, that they are empirical objects of our intellect. From the standpoint of the inductive system the world and all it contains forms but one homogeneous object. All its details are but modalities of the absolute unity. Physical phenomena or empirical materials are the universal species in relation to which all other classes are but subdivisions. It is the only substance and truth, everything else is but a quality and a relative manifestation. Solid and liquid, wood and metal, are quite correctly summed up under the notion "matter." Why should we not be justified in summing up all things under the term "empirical truth" or "empirical phenomenon?" Nothing can prevent us then from dividing it into organic and inorganic, into physical and moral, into good and bad, etc. Through the common origin all antagonisms are conciliated and bridged over. Diversity is but a form; in their essence all things are alike. The final cause of all things is the empirical phenomenon. The empirical material is the general elementary substance. It is absolute, eternal and omnipresent. Where it ends, all reasoning is at an end.

The inductive system may as well be called the dialectic or evolutionary system. Here we find what is more and more being proved by natural science, that seemingly essential differences are but differences in degree. However strict we may be in determining the specific characteristics which differentiate the organic from the inorganic or the plants from the animals, $\mathrm{Na}$ ture shows that the lines of demarcation disappear and the differences and antagonisms coalesce. The cause effects and the effect causes. The truth appears and the appearance is true. As heat and cold differ but in degree, so do good and bad - they are all relative manifes- 
tations of the same substance, and forms or classes of physical experience.

I see in the audience some new guests to whom the monism which I preach appears to be so strange and unheard of that they are very anxious to hurl against me the most insipid objections. They would like to ask how it was possible to prove that empirical material is the primary component part of all objects of science? And are there no such things as God, pure reason and moral world?

By such questions you may see, my friends, how deeply rooted irrationality is in man. God, pure reason, moral world and many other things do not consist of empirical material; they are not forms of the physical phenomenon and we deny therefore their existence. Yet, the ideas, with which this kind of reasoning operates, have appeared physically and have a real existence and can be made the subject-matter of our inductive examination. The terms physical, empirical, etc., are generally understood in their narrower sense. I supplement them therefore with the adjective "experimental."

The denominational systems of the religious, and the rational systems of the freethinkers put up different claims. The system of empirical truth, to which socialdemocracy adheres, can only be based on induction; it recognizes only those notions, doctrines and theories which are consciously taken from empirical material. From the height of that system we discover the bridge which unites philosophy with natural science. The bridge is constructed from one rock, the rock of all wisdom which consists of the knowledge that the human intellect is an inductive instrument. All specific disciplines are but applications of this general truth and science. The intellect is the commander-in-chief of all knowledge. 
The specialties of science are his subordinates. The systems of astronomy or chemistry, botany or optics are departments of the general system.

Those of my audience, who despite having carefully followed my dissertations, have not grasped yet the full bearing of socialist philosophy, I beg to consider how impossible it is to do full justice to a subject of that magnitude within the compass of a half an hour. And if I wanted to work it out more completely, I should fear to tire my audience.

However, many an opportunity will present itself in the course of our lectures to take up the matter again. For the present it must suffice to have laid bare the foundation and to have strengthened and solidified our party-consciousness by turning the attention of the comrades to the first principles of socialism. 


\section{ETHICS OF SOCIAL-DEMOCRACY}

TWO SERMONS

(VolksstaAt, 1875)

I

Comrades and Friends:

It is the desire of our party to realize that which the enlightened minds of all ages and nations wanted to realize: truth and justice. We do not want the truth and justice of the clergy. Ours is the material, empirical truth of applied science which we want first to know and then to practice. Impelled by the necessity of realizing a life worth living, we are interested in various kinds of truth, and especially also in that which is true justice, or in the " moral world."

The world cannot exist without morality and order, not because, as the parson has it, they came from heaven, or that they were, according to professorial wisdom, prescribed by some eternal code of laws, but because they are a universal, palpable need. In one of my last sermons I have already discussed the matter how we international social-democrats are trying to systematically demonstrate all our thoughts by real or experimental facts. Let us in our present disquisition of morality apply "our system" and see how it works. Also the ethical law cannot lay claim to more consideration and validity than is warranted by its material basis.

The animals, apes or rabbits, have neither shame nor 
morality, neither fidelity nor faith. At least, their moral degree equals naught. The Caffirs have but little of it, our bourgeois class slightly more, and it is left to the socialists to teach them what is really just. In other words : morality is the result of the historic development, it is a product of evolution. It has its origin in the social instincts of the human race, in the material necessity of social life. Seeing that the ideals of social democracy are one and all directed towards a higher order of social life, they must necessarily be moral ideals.

As long as mankind has been grouped in clans, hordes, tribes, nations and states, some kind of order and laws have been necessary. But we cannot tell beforehand what those laws and institutions contain, or in other words, what conduct is to be regarded as just and equitable, for that depends on the conditions in which determinate social organization lives. The most important conditions are those of production of material goods. They decide, in the last resort, what is to be regarded as just and equitable. But inasmuch as they are not unchangeable and abiding, the laws of morality cannot be eternal. Indeed, they change with the changes in political economy. The morality and laws of hunters, shepherds, knights and bourgeois differ greatly from each other. As far as political economy is based on small private means of production, the old saying holds good:

\section{"Remember hell and you are bless'd. \\ What's not your own let smartly rest."}

To-day private economy has reached its climax; the administrators of the national wealth are ardent individualists. Private property is the highest ideal; its whole mechanism, administrative and legal, constitutes the 
" moral world." What has until now been considered as moral and just is rapidly fading away. Honesty, uprightness, integrity, family discipline, diligence and thrift are virtues of the lower middle class, of respectable peasants, artisans, tradespeople, who are trying to get some legacy and to perserve it, or to carry on their little business in the way their forefathers did. Modern capital with its new instruments of production is slowly crowding out all those classes and their moral conceptions. People who get rich in one night, or who carry on machine bakeries, have a different moral standard from those who earn an honest dollar or two a day, or who knead the dough in the sweat of their brow. We don't know to-day whether five, five and twenty, or five hundred per cent. are "honest earnings" or not. Our pillars of society just manage to escape penal servitude and our state attorneys are getting corrupt. The capitalist economy has a disintegrating effect upon morality and property. Our higher classes, like the Turks, buy themselves as many women as their income permits. Polygamy and the keeping of mistresses have become the custom, the ethos, and are an ethical fact. Indeed, free love is not a whit less moral than Christian monogamy. But the reason why we object to polygamy does not lie in the great variety of one's love-making, but in the venality of the women, in the degradation of the human being and in the disgraceful rule of Mammon.

Morality in human evolution is similar to matter in natural evolution: the essence is abiding, the forms are fleeting.

"A great part of our lower classes," writes Treitschke, "have become in matters of dress and in several other external things, more like the middle classes, but in their sense of duty and honor they are 
farther than ever from the educated classes." But that "great part of the lower classes" are not only aiming at widening the ethical gulf between themselves and the other classes, they are also at work to acquire different philosophical conceptions. The religious conception of knaves and fools is selfish enough to mistake its own interests for those of the community. The ruling classes have always and everywhere shown the disposition to consider their own selfish morality as the general ethical law and have tried to impose it as such upon the people. Socialists are not likely to be caught by such priestly snares. As far back as 1848 our "Communist Manifesto" declared: "The ruling ideas of each age have ever been the ideas of its ruling class." Now Socialdemocracy rebels against all class-rule and against all ruling conceptions of duty, honor and culture. We quite admit that, despite all historical changes, there have always been officers and privates. "And so will it be forever," say the officers. But the privates have their own views about that; they cannot fail to notice that in the period which has passed since the warrior chiefs, the patriarchs, Cæsars and knights, to the present captains of industry, the people have become more and more self-conscious and independent; they find that there is such a thing as progressive development of history and arrive quite naturally at the reasonable conclusion to cut the rope which Treitschke, Sybel, etc., have laid down as the "foundation of society." The professors are undoubtedly right in saying that domination was heretofore a necessary evil or a fact justified by reason. But also human progress towards freedom is an undeniable fact. To our rulers, however, the lesson of history does not consist in freedom, but in dominion. They are only concerned with the question whether the officers will remain forever or 
whether they will have to go. We social-democrats boldly assert that they will have to go overboard in order that morality may prevail. We assert, furthermore, that the revolution of the present " moral world " is a necessary act of true morality. Thus our views of morality differ greatly from those of the ethical braggarts.

And now I should like to explain to you, dear comrades, in words as concise as possible in what the real essence of morality consists. Guided by our dialecticmaterialist conception and method, we look first, as usual in all our researches, for the material, also in this case for the ethical material, making use hereby of the terminology of every-day language. True peaches are all those which people usually call peaches. There are many kinds of them, as of morality. There it is a moral law to slaughter the enemy, to fry and eat him; here, on the contrary, the moral law commands to love the enemy and do good to him. Be a crafty rascal, says the Spartan law; sanctify property, pay the debts, commands the bourgeois. In view of such contradictions how are we to pull the sparks of truth out of the fire? Evidently by extracting the general out of the diversity, by finding what it is that has constituted the moral and just under all conditions. It cannot consist in something particular, but in the general in the abstraction of the whole moral material. To find such a rule it is therefore necessary to inquire into a sufficient quantity of moral facts; in other words, we must use the inductive method. By means of this method we find that the moral world generally consists of the considerations dictated by the social need of a given human organization. Then we find the undeniable fact that that social necessity develops with the progress of productive fosmes called civilization, that the social instinct of man grow; 
that human association becomes broader and deeper, and that morality becomes more moral. Even Christian morality demands that the limited brotherly feeling of the clan, horde, nation and state shall expand into international brotherhood. But its inordinate religious spirit, its admixture of hypocrisy and foolery, prevented the ideal from being realized. It is economic materialism only, it is but the communistic re-construction of society on the basis of material work, which will bring about the true association of men. Only from the abolition of class-rule, from the transformation of the selfish capitalistic organizations into co-operative instruments of production will issue the true brotherhood of man, the true morality and justice.

No divine oracle, no inner voice or pure deduction from the brain shall teach us moral truth or any other truth. That ideological way leads only to an insipid hankering after a supernatural, unchanging and unchangeable truth. A clear scientific result can only be won by induction; it is always based on experimental and verifiable facts; in our present case, on the established fact, that men need and serve each other. That what is right to one person is equitable to another one is as certain as that men need one another. With the growth of the necessity for mutual service among men, their association becomes more extensive and intensive, their intercourse more considerate, and their morality attains to a higher and truer standard. Social-democracy is thus quite aware that man is limited by the nature of things. But having recognized the general, or the socalled true essence of morality, we refuse to be mystified by those who want to palm off a particular phenomenon or form for the general essence of morality. Whether people marry or live in free-love, whether private prop- 
erty is sacred or wicked, whether revenge is permitted or prohibited, are customs which may be qualified as moral or immoral in the same measure as they promote or hinder human progress. And with social-democrats, human evolution is no mere ideological drivel or spiritual perfection for which there is no material test and which is therefore exposed to the wildest interpretations. With us, human progress means, as often stated, the growing control of man over nature to serve his needs. In view of that great purpose, religion, art, science and morality are simply helpmates. I repeat: the narrower or wider, the looser or closer state of social aggregation changes the law of morality. The higher or lower grade of morality is measured by the degree of social interdependence. Yet, the mere knowledge of the moral law is not sufficient to be able to make use of it in practice; the general conditions must be ripe for it. Theoretically we may easily grasp the highest degree of morality; in practice, however, things go through their historical stages. The customs of the barbarians must pass before we attain to higher ones. Where people live by hunting and fishing, there the sense of brotherhood of man cannot be as developed as where the proletarians of all countries are striving for unity.

That "all men are brothers" and that "thou shalt love thy neighbor as thyself," was well known before Christ. That thy neighbor meant any human being who most urgently needed help was likewise recognized several thousand years ago, it was turned into a dogma and hedged round with divine blessings and cursings. But that does not prevent our educated believers from maintaining in commerce and on the pulpit the diametrically opposed proposition: "Every man for himself."

Keligious truth is a fantastic ideology. According to 
it love of humanity is based on the belief in God and on freedom of will. And what is the result of 1t? The war of classes and of nations. We want to follow the opposite way and to establish eternal peace on a brotherly organization of economics. As in family life, where the man tills the soil, the woman cooks its produce and the children gather firewood, domestic harmony is based on domestic economy, and spiritual peace on material copperation, so will love of humanity only be realized when the production of material goods will be socialized. $\mathrm{Na}$ ture has undoubtedy implanted in our hearts a yearning for brotherhood. But the heart is a very unreliable compass, and even will and knowledge, as all ideological factors in general, are not to be trusted as guides if they are without any material basis. Else it would be quite incomprehensible why there is so little love of humanity among the ruling classes. If they have their pockets full of dollars they will surely help their destitute brother with a few cents. But can we call that loving kindness? However, it is not love nor help which is the guiding rule of our time, but hammer or anvil. In reality it is thus: who does not want to be a servant must try to become a master. Under such conditions it is idle to hope that people will sacrifice realities for ideal precepts. We are not sentimental enough to expect such things. Though we use moral arguments in our struggle against the bourgeois, we do all we can to stimulate our class ronsciousness. We preach eternal peace and stimulate the class struggle. We want to abolish all domination by establishing our own domination. These contradictions appear to our scholars and professors too scholarly. But already my grandmother knew that those who make every day Sunday have no Sunday, that is, where all govern nobody governs. When a handful of people now 
control all the means of production, then their rule is a curse to humanity. When however the working class overcomes their oppressors, wrests from them their power and takes over the administration of the commonwealth, then all class rule ceases and democratic rule begins. The working class is but nominally a class, in reality they are the people whose rule is no domination but a morally, that is, socially justified régime.

The bourgeois class are fantastic in theory, but in practice they are quite sober and provident moralists without any exaggerated notion of benevolence. Their practical morality is adapted to circumstances. That is as it ought to be, and we shall follow their example. But we reject their queer theories according to which morality is an idea which they believe to have received from some lofty regions. In their opinion this wicked world ought to be shaped after that idea. Here our ways separate. We conceive the real world with its human history as the living material, out of which we consciously produce the abstract idea of morality, the ideal morality. At the same time social-democracy is at work to realize the ideal of brotherhood by a social reconstruction of political economy.

Ideas, we again repeat that cornerstone of our philosophy, must be consciously based on experimental material, they must be won by induction if we desire to be clear about their meaning and import. And that applies to moral and political ideas no less than to scientific ideas. From the religious standpoint, the world is a machine which must have its mechanic. Here things are to be conceived as having their origin in the idea, as having sprung from the divine idea. The ideas are according to that a kind of transcendental matrix. Nowadays, however, sensible men are quite aware that the 
ideas of the vegetable and animal kingdom were not the models after which those objects were made, but, on the contrary, that the ideas are mental abstractions of those objects. Quite in the same manner we have to rid the ethical idea of its transcendentalism. Ideas are notions. Notions may arbitrarily be conceived in a narrower or wider sense. The notion of nature embraces the whole cosmos; the notion of organic embraces but a part of nature; the notion of plant or animal a part of organic, etc. With our ideas we embrace arbitrarily a smaller or larger part of the world wide sphere of experience. It is the nature of the idea to be arbitrarily conceived in a narrower or wider sense. The idea of animal kingdom may include animals which may be regarded as plants and, on the other hand, also men who may, perhaps, object to such a classification. The truth is that ideas cannot be strictly enclosed within their seeming boundaries. And so it is with moral ideas, their limits cannot be clearly marked. There are actions which are of less concern to society than to the person who performs them, yet we cannot deny them a certain moral value, as for instance cleanliness, temperance, etc. An eminently moral activity is the labor of the scholar, that drives him over ocean and deserts to face danger and privation, and to suffer and die in search of truth. Yet we call all these actions virtue and morality, because they have a collective or social value, which proves the correctness of our definition of morality.

In conclusion, I should like to reply to one objection: If morality has no divine origin, but is a bodily instinct, why should those be responsible who are deficient in that instinct and therefore commit crimes against the social order? Pray, remember, my friends, that the social sense is also a product of evolution; it may be 
missing or stunted in the ignorant and uneducated, who must therefore be taught by humanized disciplinary means.

In the eyes of our opponents we socialists are "materialists" - that is, people without enthusiasm for ideals who are dull-witted and only like to hear about eating and drinking - or who care only about matters which can be weighed and measured. In order to abuse us they give to materialism a narrow and disreputable definition. To such an artful idealism we oppose moral truth, that is, an idea or ideal which has either become flesh or is on the point of becoming flesh. Where in heaven or on earth or anywhere else is there an ideal which is as truly reasonable, as moral and sublime as the idea of international social-democracy? Here the word of Christian love is going to be materialized. The lamentable brothers in Christo shall become brothers indeed, and in the struggle for transforming the religious vale of tears into a real state of the people. Amen.

\section{II}

Dear Comrades and Friends:

Before we proceed with our discussion on morality I should like to sum up in a few words the essence of the foregoing chapter. We have found that different stages of human evolution have different moral laws, and even so contradictory ones that virtue is in one place what is vice in another. The ethical doctrines disagree as much as the religious denominations. Each of them claims to be the only true and genuine one. And in order to arrive at an undisputed view on a much disputed subject we followed the same course by which natural science arrives at its valid conclusions. We ac- 
cepted as moral everything which is generally regarded as such and searched as Humboldt advises, in the variety of facts for mental unity. We have founa that the various ethical codes are all at one in calling that moral which is conducive to a harmonious social conduct. Now, everybody knows, that people do not stand still like mountains, but meet each other an ${ }^{2}$ move ahead with one another. They also progress in their social relations. Society grows by degrees in volume and interdependence. The power and development of men grows in the same degree as their sociai relations become more intimate, as their sense of solidarity gains in strength and the more they consciously advance their personal well-being by furthering that of the whole community. The principle of morality is the principle of human association, and the principle of human association is progress. Social-democracy is nothing else, and desires nothing else, but social and co-operative progress, and that is the true moral perfection.

One cannot too often repeat the fact, and you, comrades, are quite aware of it, how shamefully certain words are abused, especially " morality" and " progress." The so-called progressives, who are crafty and cowardly enough to dabble all their life in politics and to ignore all social evils, have long been regarded by us as part and parcel of the "reactionary mass." Progress of that kind is just the opposite to morality. By calling retrogression "progress," and anti-social selfishness "morality," they corrupt the language and notions of the people. And they don't do it unconsciously either. It is a part of a deep scheme laid with deliberation by wicked immorality. Whenever morality demands freedom, freedom of expression, freedom of press, etc., or whenever human evolution demands any other con- 
cession, you will soon find certain people busy with castrating these ideals and pawning such gags, under the name of freedom, off on the public. Democracy wants universal suffrage, but some Napoleon or Bismarck, if he finds it necessary to accede to the democratic request, takes the sting out of it and presents a harmless toy to the masses. Such have always and everywhere been the ways by which the nations are misled. It is therefore necessary for social-democracy to know that words are but names for ideas and that ideas have a flexible meaning (in proportion to the scope, interrelation, time and place of the things they are based upon. Editor). The usual misunderstandings of this logical chapter are taken advantage of by our oppressors to juggle with words, ideas and things and to delude the people. Else it would be quite incomprehensible how such a natural thing as morality can be presented by our academic quacks as a metaphysical wonder!

In order to get a clear conception of morality let us compare it with a tool. The tool is as eternal and yet as changeable as morality. Can a knife of the stone period be regarded to-day as a knife? It is surely an antiquated knife, but no more a knife in the modern sense; a knife of to-day must be from steel, and of modern finish. But just as a knife consists generally of a handle and blade, so is morality in general the subordination of personal desires to the local, national and, finally, international welfare. Thou shalt subordinate thy immediate passions to general health and life, thy personal needs to the need of society - that is moral, reasonable and necessary. Whatever social welfare temporarily requires, is stipulated by some law. The ethical theory of social-democracy is in accord with the real state of things. We see in the political admin- 
istration of the nation the guardian of morality, but we regard it also as our duty to be vigilant and to prevent the government turning a changeable and transient institution like the state into an eternal and holy idol, or promoting immoral reaction instead of moral progress, and selfish vice instead of communistic morality. By subordinating private interests to the commonwealth, 1 social-democracy manifests the sense of true and genuine morality.

"The words," says Schopenhauer, " are no more masterless, and to lend them a different meaning from that they had until now, is simply an abuse." In colloquial use the word morality stands for an empirical and live fact, for a real, palpable need whose cry is: "To live and let live." Morality belongs to the same category with all other profane things. It is a natural quality inherent in man. Human beings without any moral sense are rare exceptions, which, when met with, are to be contemplated with the same judicious mental attitude as some other anthropological or physiological abnormities. According to recent researches in the domain of natural science "the image of God" is a product which with its hair, with its body and soul, with its religion and morality, descended from the animal kingdom. "As far as I am concerned," says Darwin, " I am as willing to derive my descent from that heroic little ape which defies its dangerous foe in order to save the life of its guardian, or from that old baboon which, coming down from the hills, victoriously takes away its young comrades from the amazed dogs - as from a savage who finds pleasure in torturing his enemies, offers up sanguinary sacrifices, commits child murder without any compunction, treats his wives as slaves, knows no decency

1 Of course in conscious furtherance of the personal interests.-- Edror. 
and is controlled by the grossest superstition." And indeed, my friends, it is more praiseworthy to work oneself up from brutality to the social-democratic ideal than to sink from a heaven-born Adam to the Christian worm, who, conscious of his sinful nonentity, creeps in the dust of humility.

Progress is moral, and morality is progressive. As all other things in the world, morality is in constant evolution. It begins its existence with the animal, but does not win the name until it has grown in man. Fitness and efficiency, that is morality and virtue in the life of our species must, as everything else, struggle for existence against arrant reaction. Worthless survivals are known in biology as rudiments, they are reactions of a past generation upon their posterity. We came to know the same reactionary element as the vicious enemy of historic evolution. Just as there are men who move their scalp monkey-like or their ears mule-like, so are there brutal progressives with an atavistic morality.

It is well known that one progressive reform supersedes the other: true progress is therefore the radical, the farthest-reaching progress. Truly moral is only the most intimate and altruistic social organization. That the big is small in relation to the bigger, the small is big in relation to the smaller; that what is a heavy burden to man is an easy thing to the ass - the relativity of qualities big, small, heavy, etc., is generally acknowledged. None the less I think it necessary to draw special attention to the relativity of the moral adjective. It happens with moral laws as with tools. In the course of time the cunningly contrived tools come to be regarded as ridiculcusly clumsy; and what was once moral becomes in the course of evolution immoral. Compared with socialistic morality, bourgeois morality is an immoral 
disgrace. Morality thus demands radical progress or an unbroken series of revolutions.

With the final triumph of social-democracy, human culture will start on its road of conscious and endless progress. Until now mankind advanced in a more or less unconscious manner. It is only we social-democrats who deliberately put the principle of progress to the front. Until now all progressive parties had defined limits which, when once reached, checked their movement and turned action into reaction. The greatest heroes of civilization and thought finished by clogging the wheel of progress which they had once accelerated. Moses, Aristotle, Christ, Luther, Kant and Hegel had a most beneficial effect on the course of history until they became saints. Then all their celebrated systems turned into as many stumbling blocks. Of course, our wiseacres have a ready answer to that. They assert that those men of light and leading have been misunderstood by humanity which corrupted their teachings. But as true progressives we know better. Those heroes could not have a permanent influence, because they had not penetrated to the true principle of morality. They mistook the particular for the general, and morals for morality. All ethical prescriptions are good, but in a limited sense. Only the limitless progress is always good and absolutely moral. To lay down regulations for all times and conditions, as our system makers claimed to have done, is in the highest degree immoral.

We have seen that morality is based upon the general need for social co-operation. With the growth of that need, morality and civilization grow. The continued development of morality is as necessary to the welfare of our race as food for the body. Any moral prescription which claims to be more than a local or temporary ex- 
pediency turns necessarily into an immoral limitation, just as a prescribed bill of fare turns finally into an unbearable diet. As bread is a general food, so is truth a general virtue. But remember, my friends, that that fact is by no means a metaphysical prescription with a claim to eternal validity, but an empirical rule which admits of exceptions. An absolute right is, like an absolute truth, theological or metaphysical moonshine. The moral world has but one commandment: permanent social progress, limitless social evolution.

Christian irrationality, which separates the soul from the body, separates also the moral from the physical progress. It removes morality from the sphere of life and action into the narrow closet of feeling, into the secret chamber of the heart. No doubt, a good heart is one of the conditions of sociability, but that is formed in human intercourse, in society, and not in a monastery. Although nobody goes now into the solitude of the forest to live on roots and herbs in order to get a moral education, yet the monastic principle of morality is still prevalent. Where the universe is believed to have sprung from God's head, and the truth from pure reason, or kindness and justice from the inner voice of the heart, there the wrong path of ideological deduction is still trodden. The undue separation of the moral from the corporeal and of mental culture from material well-being is a theory which appears to be especially made for the benefit of the exploiters of the people. The bitter toil of the people is to be sweetened by moral sugar. The ruling classes, while praising misery, sorrow and pain as a moral crucible, are giving themselves the immoral pleasure of the separated progress of their body. We social-democrats, though distinguishing things and conditions by names and conceptions, are quite aware that 
in practice all things merge into one another, especially the physical and the moral.

Spiritualistic as the language of the monks was, serfdom, tithes and charity were the material support of their moral twaddle. The same tune, though with some variation, is played by our capitalists. They know the hardships in the life of Robinson Crusoe, but refuse to know how their private wealth has been got out of social labor. Their interest prevents their seeing how deeply immoral or unsocial an economic system is which pays the "neighbor" a disproportionally small share of the product he created by an excessive amount of dire work.

Exact, inductive science teaches the social-democrat that the moral world or the brotherly progress is still a socialist scheme, though at the same time a categorical imperative which impels him to work on unswervingly and with all the moral earnestness at his command for a radical transformation of political economy. No parson and no professor shall talk us out of that. 


\section{SOCIAL-DEMOCRATIC PHILOSOPHY}

\section{SEVEN CHAPTERS}

(VolksstaAt, 1876)

I.

It is with pride and joy that our comrades look upon the successes achieved in a comparatively short time in the cause of Socialism. The numerous adherents, the large concourse we owe, I think, to the sense of degradation and misery which burns in the hearts of the people. But the splendid discipline, the never-failing tact and the harmonious working of the rank and file we must ascribe to the clear grasp and the systematic comprehension of our theory. Without that the socialist would be to-day what he was heretofore: tender-hearted, but muddleheaded.

The first English and French socialists whose thoughts flashed through the horizon of the end of the eighteenth century, were not slow in recognizing the exploiting and antagonistic character of our champions of " free property." They saw the negative element, the taint of the deadly disease, within the heart of the factory system. They foretold with ingenious lucidity the decay of the middle-class, the slow, but inevitable divorce of the peasantry and the artisans from their means of production, the transformation of the small producers into wage-slaves, finally the rapid increase of misery and of the number of the proletarian class. But they failed 
to recognize that the elements of the positive remedy are to be found in the laws underlying economic developments, and that human history in its evolution does not only bring forth problems, but organically contains their solution. In their purely ideological conception of the world they believed it ought to be possible to invent some scheme for the building up of a true and just society. This error of judgment could not but lead to day-dreaming. Every one of these amiable dreamers looked for proselytes and went with them to America or Icaria. One built up a Harmony, the other a New Jerusalem. There were as many sects as ingenious minds to found them. They exhausted themselves in discussing Republic and Monarchy, dictatorial or constitutional government, limited or universal suffrage, and all the intermediate forms of government. They brandished all manner of flags, two- and three-colored, blue and red ones. However, for logical saquence, scientific consistency and harmonious action, one searched in vain.

Amidst this chaotic state of social and political speculation appeared Marx and Engels who, besides their warm devotion to the cause of the penple and to socialism, possessed the necessary philosoph ${ }_{1 c}$ knowledge to clear social science of vague guessings and imaginings and to give it a body of positive doctrines. Philosophy revealed to them the basic principle that, ir the last resort, the world is not governed by Ideas, but, on the contrary, the Ideas by the material world. They agreed that the proper forms of government and sox.ial institutions are not to be looked for in the inner recenses of the mind, but must be found through the investigution into the material conditions of a given period. The materials for socialist investigations are supplied by the exiating. capitalist society with its political economy as ther 
pable body whch consumes and produces concrete commodities.

In his "Capital," Marx dissected that body and exposed clearly how our social misery is the necessary result of an economic system whose plentiful production by social labor stands in glaring contradiction to its mode of private usurpation. The small number of employers and their set receive as interest, rent, dividend, etc., the whole profit, while the workmen receive a wage, a kind of lubricant to keep the social machinery going. Marx was the first to recognize that, on the whole, human welfare does not depend on the enlightened statesman, but on the productivity of social labor. He recognized that the productive forces and the efficiency of society are by the nature of things impelled to expand, that this expansion led us from barbarism to civilization, that the progress of economic productivity must necessarily lead us out of the glaring contradictions of civilization to the socialist state, to communist liberty, equality and fraternity. $\mathrm{He}$ recognized - and this recognition is the bed-rock of social science - that human salvation depends on material work and not on spiritualist moonshine. Henceforward we look for salvation not to religious, political and judicial enlightenment, but we see it organically growing out of the development of social economy. Science or education cannot bring it; productive labor must do it, which, through science and education, can be made more productive.

To which does the primacy belong; to mechanical work, or to mental speculation? That's the question. At the first sight it might appear to be a scholastic conundrum; yet, for the purpose of gaining a clear mental vision, it is of vital importance to solve it. The question is, indeed, an old one; who is right, the idealist or the 
materialist; but now the question has been so far cleared up that there can be no doubt as to the answer. We, of course, are materialists and thus acknowledge the material factors to have the primacy. Our opponents brand us, therefore, as enemies of culture. In reality we are only opponents of those dreamers who divorce scientific training from material work, making out of the former something supernatural which transcends all laws of mechanics. Science and education are in our eyes very valuable means, but means only, while the productivity of labor is the higher end. It is in the first instance the necessity for an ever increasing productivity of labor which forms the real impulse of scientific investigation and progress. In the second instance, of course, science reacts most beneficially on the method of labor.

Yet the question as to where the primacy belongs has a more comprehensive meaning. It involves the cardinal problem, is the world "created" by some monstrous, transcendental schemer, or is our scheming, though no doubt of considerable importance to us, quite a secondary attribute of the monstrous every-day world; we want to know which takes the precedence: thought or being, speculative theology or inductive science. Men are, and have a right to be, proud of their intellect, but it is puerile to give to a thing, which appears to them of primary importance, the primacy of the world. Idealists we call those who exaggerate, idolize the worth of human understanding, turning it into a religious or metaphysical hanky-panky. This school is on the decrease, its last survivals are those who have long ago given up all religious superstitions, but somehow stick to the "belief" that conceptions of freedom, justice, beauty, etc., are shaping human destiny. To be sure, there is a certain truth in 
that; but in the first instance it is the material world which forms the substance of our conceptions, which determines what is meant by freedom, justice, etc. It is, as we have said before, of vital importance that we should be clear about that, for on it depends the method of giving our conceptions the proper meaning. Indeed, the question as to which is primary, mind or matter, contains also the problem as to the right way to justice and truth.

Impelled by material necessity, Socialists look for the salvation of humanity. Philosophic thought based on facts has given us the guide. We find salvation not in idealistic shuffling, but in the material production. If the nature of things demands that we should get the maximum of result in the minimum of time, then we must work as bourgeois society does: with colossal machinery and for a large public. The small workshop and the small holding must go. The great capitals shall flourish. That's the work of our liberals, and they have done it so well, that our Empire, our " free" institutions, our parliamentary talking shop, our party discussions about free trade and protection, our no-popery-struggles and other Bismarckian tricks are no more able to master it.

The productivity of labor has become so prodigious that all the legal and economic forms have become inadequate. The result is a series of crises with its usual symptoms: financial panics, bank failures, shutting up of factories, and unemployment in the ranks of the working class. Why? Because the productive forces have outgrown the miserable relation between capital and labor. Under such conditions the minority are able to live in luxury, while the majority are deprived of the necessaries of life. But the number of spendthrifts are 
too small and the stock is so embarrassingly great that capital cannot be profitably employed. Business is at a standstill, and there is no demand for goods. The only way out of this calamity is participation of the masses in the consumption; the wages must be increased and labor time reduced. But the well-fed capitalist, though in danger of suffocating in his own fat, is too narrowminded to pay the producer of his wealth, the worker, well and to keep him in steady employment. Our Liberals refuse even a liberal lubricant for human laborpower.

However, circumstances are stronger than the selfish will of the bourgeois. The stock is gradually sold, business revives, the old cycle of fraudulent booming begins again and the wages go up. What a strange, paradoxical thing this bourgeois world is: the more plentiful the supply the greater the misery. One should think men live on bread. But no. Let the soil yield thrice as much, as long as you don't work an overlong day, you will starve. Should the goblins of the fairy tale return and do all our work during the night, nine-tenths of the nation would have either to starve or to make a revolution. In the past the lack of capital made thrift a virtue. The increase of the wealth of the nation increased also the means of employment and thereby the sources of life of the people. For, as it was said before, the people have not in the first instance been living on bread, but on labor. But now with the increased capital the productivity has reached such a degree that there is not sufficient employment. Then the superfluity engenders misery. Not only Social-democracy, but the national economics demand a larger consumption, a wider market for its products. Even an increase of wages and a reduction of the labor time are no more than palliatives. As the 
productive forces in the past needed for their fuller development the abolition of serfdom and of restraint of trade, in short, demanded the liberal bourgeois policy, so do they demand to-day the abolition of the capitalist mode of wage-labor and its substitution by the Socialist organization of communistic labor.

The subjective creed breaks up into different denominations - and the various parsons are at loggerheads. Objective science is unanimous; engineers don't quarrel about principles of mechanics. The theoretical unanimity of Social-democracy, which we mentioned before, proceeds from the fact that we don't look for salvation in subjective schemes, but we see it growing as a sort of organic product out of the inevitable course of actual development. All we have to do is to facilitate its birth. The irresistible evolutionary process, which formed the planets, and hardened molten matter into crystals, and brought forth in succession plants, animals and men, is also tending irresistibly towards a rational application of labor and towards an uninterrupted development of the productive forces. It is imperative that production be rationally managed under all circumstances. In all periods of civilization, no matter how greatly they differed from one another, it was essential - and such is the logic of things - to achieve the maximum of results with the minimum of effort. This instinct produced by our physical constitution and need, is the universal, the primary cause and the foundation of all socalled higher, spiritual developments and progressive movements. The unfolding of the productive forces is the point of departure, the formative factor which builds up states, determines forms of governments, creates parties, and clears up and perfects the notions of liberty and justice. The productive forces, having been impeded in 
their development by guild regulations, broke those medieval fetters, and created the capitalist system which, in its turn, is rapidly becoming a hindrance to the further development of production. Therefore it is necessary to allow the people to take their historically-due part in the consumption and to extend the demand for goods. The old system must go in order to bring morality, liberty, equality and fraternity to a more perfect state. Forward! is our watchword, whether we like it or not.

The hope of Social-Democracy is based on the organic necessity of progress. We do not depend on the good will of any man. Our principle is organic, our philosophy materialistic, but our materialism is richer in essence and more positive than any of its predecessors. It absorbed the Idea, the antagonism of matter, it mastered the domain of Reason, and overcame the antagonism between the mechanical and spiritual view of life. The spirit of negation is with us at the same time positive, our element is dialectical. "Once my work on Economics finished," wrote Marx to me privately, "I shall write a Dialectics. The laws of Dialectics have been formulated by Hegel, though in mystical form. What we have to do is to strip it of that form." Being afraid it might be long before Marx could undertake such a work, and having since my youth independently thought a good deal on that subject, I shall try to throw some light on dialectical philosophy. It is in my opinion the central sun from whom light goes forth to illuminate not only Political Economy, but the whole course of human development, and it will finally, I expect, penetrate to the "final cause" of all science.

The comrades know that I am not an academician, but a simple tanner who learned Philosophy by himself. To its exposition I can but devote my hours of leisure. I 
shall therefore publish my articles at shorter or longer intervals, whereby it will be my endeavor rather to make each article readable for itself than to write a book with chapters depending upon each other. And not attaching much importance to the learned phraseology, it will be easier for me to avoid unessential matter and unnecessary flourishes which only tend to obscure the subject. On the other hand, I must ask the reader to bear in mind that the art of popular and easy exposition has its limits. To be sure, what one thinks out clearly, one can express clearly. But that truth is relative. Without some preliminary knowledge of a subject it is impossible to talk about it. The peasant is made fun of on the sea; he knows nothing of hawsers, square-rigs and sails, and the sailor cannot speak of his business to him. Neither could I enter into a philosophic discussion without taking some preliminaries as granted, else I could not help falling into platitudes which would neither serve my purpose nor satisfy my taste. Any reader who, in the course of my articles, might complain about obscure writing, would therefore do well to search first for light within himself.

II.

Like my sermons, which were preached with the intention of desecrating the pulpit, my exposition of Philosophy has the intention of degrading that high mistress which, as Ludwig Feuerbach stated, is the devotee and sister of Theology. Social-democracy will get those old spinsters out of the way. As far back as 1844 Frederick Engels spoke in the preface to his "Condition of the Working Class in England" of the end Feuerbach put to all philosophy. But Feuerbach was so intensely occupied with the theological devotee that he had very little 
time and mental energy left to join issue with the other sister, the philosophical one. His final solution of philosophy is more implicit than explicit. Yet this disciple of Hegel proves indirectly the truth of Marx's word: "The true laws of Dialectics are to be found in Hegel, though only in a mystical form." Feuerbach and Marx, both Hegelians, arrived at the same result by the same method which Feuerbach made use of in his analysis of religion, and Marx in his analysis of social economy.

This historic course proves that our social-democratic anti-philosophy is the legitimate descendant of Philosophy. Owing to this descent we may place it right next to that of our academicians and overtopping them by one length, we may ask them: What do you still want? And when it comes to the subject-matter itself and its proofs, we are so sure of our case that we safely may look from up high down on these learned gentlemen. For us there is no need to appeal to Aristotle or Kant, because we deal with a living thing which is patent to all unprejudiced and unbiased minds. Just as the proof of scientific laws is to be found in the experiment, so are our arguments in conformity with fact which is the basis of our anti-philosophic philosophy. Therefore, it is superfluous to corroborate our arguments by extracts from Greek, Latin or other learned authors.

It may be somewhat puzzling to the uninitiated to find that, while professing the intention of disparaging philosophy, we are proud of our philosophic descent. Yet the contradiction is easily explained: As the alchemistic errors generated modern chemistry, so have the errors of Philosophy generated a Universal Doctrine of Knowledge and Science. An old man who desires to be able to start his life again, does not mean to repeat it, but to improve it. $\mathrm{He}$ recognizes the ways he has walked as wrong ones, 
yet he cannot withhold the seemingly contradictory acknowledgment that they brought him wisdom. The critical attitude taken up by the old man towards his past is just the attitude of social-democracy towards philosophy. It was necessary to struggle through the wrong path in order to attain to the knowledge of the right one. Now, in order to be able to follow up the right way without being misled by any religious or philosophical maze, it is necessary to study the most mistaken of all mistaken ways, namely Philosophy.

Those who take this advice literally will surely think it absurd. For, how could the wrong path lead to truth? But the reader would do well not to stick to the letter but to seek the sense of it. The famous dictum: "My religion is no-religion" illustrates for instance that not always is $a a$, but that $a$ turns into $b$. It is the peculiar character of the things of this world that they are not crystallized or fossilized, but they are in an eternal flux, ever changing, ever in a process of transformation, of rising and decaying. All reality undergoes constant changes, and so limitless is the movement of the world that every thing at every moment is not the same thing that it was. The language therefore is not able to do otherwise than to give one name to various forms or things. Also philosophy could not escape the universal law of movement and mutability, and it has undergone such changes that it is a great question whether, like modern Christianity, the new thing should retain its old name for reasons of expediency, or should get a new name to match. Social-democracy has decided against " religion," and I am now pleading that we decide against philosophy too. Only for the period of transition do we use the expression "Social-democratic philosophy." In 
the future we shall probably speak of dialectics or of the general doctrine of knowledge.

Who are we, where do we come from, and where do we go to? Are men the lords and masters, the "crown of creation," or are they helpless creatures, subjected to wind and weather, and to trouble and toil? What is, what should be, our relation to the things and men about us? That is the great question of philosophy and religion. In the language of the former, the younger sister, that question is expressed in a more rational way. She does not expect the reply from supernatural, divine spirits, nor from ecstasy, but puts it before the sober intellect which exists empirically in the brain. It is the characteristic of philosophy that it snatched away this " great question" from religious sentiment and placed it before the organ of science, the faculty of knowledge, to find the solution.

Less than of our intestines can we know, without special study, of that mysterious thing which as force of thinking dwells in our head. Primitive wisdom used it as people use their stomach, without scientifically inquiring into its construction. Having, however, reached the point when men consciously set before the intellect the great question about existence, they gradually began to inquire into the intellect itself, and the critique of reason or the theory of cognition became the great question.

It is well known that the object of the medieval schoolmen was to support the religious dogmas by rational arguments. They did something that they didn't intend to do: they put reason above religion; they practically made reason the supreme being. Something like it occurred to Philosophy. She proposed to solve the great question of general existence scientifically, but not knowing how to take it in hand, she turned it upside down, 
and the scientific solution of the process of thinking, the theory of cognition, became to her the real and fundamental question. The most remarkable philosophical works, especially the most recent, prove, though unconscious to their authors, that change of procedure. Even the title of the principal works, from Bacon's "Organon" to Hegel's "Logic" and Schopenhauer's "Quadruple Root of the Proposition of the Adequate Reason" indicate at once the situation.

The past great philosophers, as well as their present small successors, could not help but acquire more or less of a presentiment of the fact that all the so-called mother of sciences brings home from her excursions really consists in no more than the special theory of cognition. Quotations by the yard could be brought together to prove that statement, but also to prove that that presentiment did not arrive at clear nor consistent consciousness, and that the professors and lecturers of philosophy are quite confused with regard to the problem, the object and the significance of philosophy. None of them has been able to clear his mind of the remnants of superstitions, of phantastic mysticism which dims their vision. Irrefutable evidence for this was given lately by Herr von Kirchmann, who in a "Philosophical lecture in popular language" said, according to the Volkszeitung of January 13, 1876, that philosophy was neither more nor less than the science of the highest conception of being and knowing. . . . With the special sciences she has in common the subject of their inquiry and contemplation, the Universe with all that is in it, and she uses the same means . . . those of the speculative thought which is striving for a higher unity. The main difference between the special sciences and Philosophy consists particularly in the method, for the latter proceeds 
from no given premises whatsoever, but from a purely spirit-born principle as a starting point. Of her usefulness Kirchmann didn't wish to speak, but of her significance for the great spiritual domains of life, of humanity in particular, for religion, state, family, ethics ; for neither the courts of justice nor the police, but Philosophy alone was able to protect those great institutions which were attacked with as much boldness as cynicism.

There you have the old devotee made young.

Her name is "Science of all the highest conceptions of Being and Knowing." That is her name in common parlance. But I should like to see that common sense that could make sense out of that common parlance. "The highest conception of Being" deals perhaps with the conception of the highest fixed stars, or is there still anywhere a higher "Being" left? But I take things too materially; we must remember we are not talking astronomy, but Philosophy, or "Science of the highest conceptions of Knowing." How can that be materialized; what positive sense can we derive from that phrase?

Philosophy "has in common with the special sciences the object of their inquiry: the Universe with all that is in it, and uses the same means to her work, namely the thought." But in what does the difference, the distinction of Philosophy, consist? Kirchmann says in the method. Granted that Philosophy and natural science have the same object of inquiry and the same instrument, but a different way of handling. Now, what is the result of that difference? The results of natural science are known. But what has Philosophy to show? Kirchmann tells us the secret: She protects religion, state, family and morality. Philosophy is not a science, but a safeguard against Social-democracy. Then there is no won- 
der that Social-democrats have got their own Philosophy.

One must not think that Kirchmann was an exception, and was no real philosopher. On the contrary, he is a man of great reputation and speaks quite in harmony with the Faculty. Especially the dictum about "proceeding from no given premises whatsoever," bears the hall-mark of the official Philosophy. The "special sciences," as well as common sense, get their knowledge through the intellect, from the material world. They make their researches with open eyes and ears, and what can be seen and heard the Philosophy calls "given premises." In her extravagant conceit which seeks the " eternal treasure," she looks upon the "appearances" of the world as upon rust-corrupted and moth-eaten things. It is true that it is generally asserted that she is based on all accessible results of the different sciences, but this is only a concession which she is compelled to make an inconsistency quite in keeping with the general philosophic confusion. She speaks thus with the left corner of the mouth, while with the right one she speaks of " the purely spirit-born or deductive principle to start from," of no materially preconceived notion whatsoever, which she is running after without ever catching up with it. The whole clap-trap comes really to this : Philosophy is no science but the radically false way used by the mind. Its result is to be found in our inference that by mind alone no truth and no principle can be attained, and no life problem can be solved, but that the human faculty of cognition is an inductive or matter of fact dependent instrument which always and everywhere presupposes experimental material.

This is the lesson that classical Philosophy teaches us. Its successors and epigoni are, for reasons easily understood, not able to grasp it. They are called upon to 
defend religion, state, family and morality. As soon as they renounce such calling they cease to be philosophers and become Social-democrats. All those who call themselves philosophers, professors, university lecturers, have. despite their: free-thought pretensions, not yet freed themselves from superstitition and mysticism; they are all of the same kidney and must be regarded, in the main, from the above social-democratic point of view, as a compact mass of uneducated reactionaries.

\section{III.}

Whence do we come, whence the world, and where are both going to? What is the meaning of existence, of our sentiments and of the natural phenomena? Thus asks man, and man is a great questioner - that is, a great fool. As the proverb has it, one fool can ask more questions than ten wise men can answer. Yet that question is the cardinal question which has been and will be put by all men at all times. Foolish is only the form in which the question was put first by religion and then by the progressists, also called philosophers. They questioned in a hazy, general way and - " only the fool waits for reply."

A reply, a clear, rational and positive reply, can only be expected when we specialize after the manner of the "separate" sciences. We can only get at the whole by means of its parts; the Universe can only be understood by climbing up, as it were, its particular forms; we can only reach the general through the special. One must first ask, where do I personally come from? Whence my father and grandfather? What is the eye? What is the ear? What function have the liver or the kidneys to perform? To such questions science replies in a definite 
and exhaustive manner. Botany deals with trees, shrubs and herbs. Astronomy with stars. The "great question" thus split up, specialized and reasonably formulated can be reasonably and scientifically answered. If, however, such reply does not satisfy the inquisitive student, if there still remains something obscure and unexplained, we have none the less this advantage over religion and philosophy, that we know the method by which we may proceed with our questioning and searching for a reply, and we need not foolishly wait, believe, hope and speculate.

Thus, the "method" is pointed out to us to be the distinguishing mark between Philosophy and the special branches of science. Now, the speculative method of Philosophy is nothing but a stupid questioning and groping in hazy generalities. The philosopher, having no material to work upon, tries to evolve his speculative wisdom from his head like the spider its web from its hindparts! Nay, the philosopher goes even farther than that, he refuses all material and given premises. His philosophic fabrics have thus less of a real connection than the cobwebs of the spider.

We greatly underestimate the bad effects of this abuse of method if we assume that it does no harm to practical life because it is locked up in those learned works which only few people care for. Those learned books are but the most palpable collection of a wide-spread poison with which humanity has been infected from the beginning, and from which it is still suffering. An instructive example was given lately by the learned Professor Biedermann in Leipsic in his controversy with the workingmen. He wanted the Socialists " to give him, instead of vague and indefinite suggestions, a clear picture of how the future society must be organized and according to their 
demands shall be built up; especially as to its practical consequences."

Before giving Biedermann a rational answer it would be, before all, necessary to teach him how to put a question rationally. He is not acquainted with the theory or the science of cognition. Therefore he fails completely to recognize our ways. We are not idealists who dream about the conditions of a future society "as they must be and ought to be." When we are trying to think about the future society we first proceed from the materials at hand. We think as materialists. God Almighty had the Universe in his head before he made it; his ideas were sovereign and had no need to take notice of realities. This superstition of the sovereignty of the Idea is still rooted in the heads of the philosophers; from it proceeds that demand that we should first project an elaborate picture in all its details of the future society, before attacking and "destroying" the present. The old Socialists, Fourier, Cabet, etc., committed that mistake and we are therefore told to take an example from them. Herr Biedermann fails to understand us, and our ways and our cause. We don't deal with the future in the way the speculative philosophers do; we deal with it as practical men. We don't build castles in the air and don't count the chickens before they are hatched. It is surely foolish to go into business without any forethought and plan, but it is still more foolish and quite after the manner of the fantastic enthusiasts not to reserve to oneself liberty of action with regard to the special conditions as soon as they are at hand - it is like a person who intends to deal in cotton prints and is quite in a hurry to project its stellular and flowery figures which might please the customers while he knows neither his customers nor their taste. We have surely a general con- 
ception of the constitution of future society, but we leave its details to the times and circumstances when that conception will have to be realized. Our opponents are undoubtedly entitled to demand from us a clear statement of principle, but they cannot reasonably demand the particulars beforehand. These must be reserved to the Socialist legislators who in their time will have to frame bills for the legislative bodies. And history bears out this statement: What leader of the bourgeoisie, when fighting against feudalism, would have been able to describe all those different and multifarious institutions of bourgeois society, as lawyers, notaries, mortgages, bills of exchange, shares, police and a hundred other things which capitalism has brought in its train? The leaders of the bourgeois movement of freedom of trade and commerce, didn't trouble themselves prematurely with particular projects; they simply demanded from their aristocratic. oppressors " the Rights of Man," and they left meanwhile the question concerning particulars unanswered. They reserved to themselves liberty of action to meet events as circumstances required.

Take care of the principles and the details will take care of themselves; time and circumstances will bring them out with unfailing certainty. Thus acted the leaders of the bourgeoisie. They refused to weave without material thread. And what all practical men of the past have done instinctively, we Social-democrats are doing with a clear consciousness given to us by the scientific method of cognition.

We, too, demand the restoration of our human rights, and demand our socially due portion of the products of labor. This wish and will of ours is no idle speculation, but the natural outcome of present material wants. And so is the communist economy quite in harmony with the 
nature of the present social system; it must come; its materials are being produced and multiplied daily. The capitalists are the real silk-worms. As soon as their silk in the shape of accumulated productive means is spun by the wageworkers, we shall know how to take it in hand and weave it. The premature question about the future When, Where and How need not trouble us, it is indeed an idle "philosophic" speculation.

Our platform demands from society, by means of the general duty to work, the satisfaction of all reasonable human needs. Our opponents want us to elaborate clearly the "practical consequences" of that idea. They don't like our negative and critical attitude. We should build up and show " how it could be done" - of course, not in a serious, not in a palpable and practical way, but on paper, by means of harmless theories and ideal descriptions. They fail to recognize that our method is not purely ideological. In our real work we use our brains after the manner of science, and not of idle speculators. Who wants to build must lay the axe unto the roots of the existing trees, and, before all, bring down the tallest and mightiest. But this radical cutting work we must not do. We should construct the future society in spirit only, in theory. And yet they want us to do this theoretical work in an exact and scientific way. Well, let us first critically assort the material on hand. However, the "negation" of the unfit is inseparably connected with the construction of the better. Criticism of the present is the indispensable condition of "improvement."

That work on a small scale is not profitable and that private property on a large scale exploits the workmen, is an empirical fact; it is won experimentally by induction and did not fall into our heads from the nebulous region of hazy generalities. From that fact we deduce, 
as a "practical conclusion," the demand for co-operative work on a rational and communal scale.

Since Adam Smith, and even earlier, it is acknowledged that labor, when applied to nature which is obviously nobody's property, is the creator of all capital and rent and profit. That labor is not carried out in a private way, but that it is divided among the members of society, is as much a truism as the phrase of the "division of labor." That the division of labor as practiced to-day, is not carried out in a systematic manner, but that it is more a matter of chance which produces a glut in some articles and scarcity in other articles of the market, moreover, that the division of the produce defies all justice and humanity, are bare facts which do not admit of any doubt. From all that we draw the "practical conclusion," that it is in the interest of the community to abolish private property of the soil, and to transfer all the means of production, created by labor, into the possession of the community, which will share out the duties and the rights, the labor and the produce of labor, in an equitable and democratic way among all its members, according to social needs and irrespective of individual whims.

The special question as to the time, means and method of the transformation, whether it should be done by means of a secret treaty with Bismarck, or by a petition to Parliament, or by a barricade fight in Paris, or by female suffrage in England - all such considerations are extravagant, untimely and foolish. We bide our time and the material which must be submitted to our understanding before we can rationally think the matter out. Our cause is getting clearer every day, and the people are daily becoming more enlightened.

Constant propaganda, the removal of prejudices of the public, untiring criticism, will effect much more than all 
speculation about the future state of society. Its general outline is given in an unmistakable manner by the present actual nature of things. The determination of its special forms and details must be left to the enquiries of future times.

The earth is wide, the sun warm, the soil fertile and the arms of the people are now strong enough to satisfy all reasonable needs of the masses, be they three times as numerous as at present. But men like Biedermann are in doubt if we have enough brains to be able to divide fairly the plentiful products of labor. $\mathrm{He}$ is especially anxious to know "whether all members will have the same claim to a share in the produce," that is, whether all workingmen will have only rye bread for breakfast, or whether professional work will be rewarded with an extra roll of white flour. I am not used to think much of my personal dignity, but such question I think unworthy of a Social-democratic philosopher, because its solution rests with the social needs of the future community.

Biedermann speaks of "all partners of a labor product." But rightly conceived, there is only one partner, the working people ; and only one product, the working people's product. Only from this social point of view is it possible to conceive of a just distribution, while the conception of different partners with different rights and privileges to their different products leads only to confusion and serves only those who want to fish in troubled waters. It is not good for man to be alone, says the Bible. It is likewise not good that he should work alone. The individual as well as the small societies should join the whole. Looked at from the standpoint of the whole the solution of the problem of the future society is clear enough, and from this general principle the "practical consequences" will follow in the right time 
and with the help of inductive enquiry quite rationally. But what about forced labor - " the limitation of one's liberty does not agree with the ideal state." Well, should we evolve the conceptions of liberty and ideal in a fantastic-speculative way out of the pure reason as the German professors do, then, of course, they would not agree with one another. We, however, do not seek in metaphysics for freedom, neither do we look for it in the salvation of the soul from the prison of the body, but in the adequate satisfaction of our material and intellectual needs which are all of them perceptible and bodily felt. Compulsion to labor is, properly speaking, a law of Nature and is only experienced as a limitation of our personal freedom as long as there are masters over us, who deprive us of the produce of our labor. Does the wellpaid official consider his prescribed service as a "limitation of his personal freedom?"

No doubt, the adequate satisfaction of all rational needs through society, that is, the social-democratic organization of economics, is a big problem. Such problems are not solved by any individual personality, but by history, by social evolution. And it is puerile to set them before any person, no matter how ingenious, for solution. We go to work in a practical manner, and the first thing is to organize the workingmen, teach them how to defend their own interests and to overcome their powerful and numerous opponents, at first symbolically, by logical arguments; and if they prove themselves impervious to all logic and persist in their actions against all morality that is born and bound by the facts of social necessity, and the analogous order of things, then with the mailed fist.

Yet, we need not fear that it will come to that. We gain daily in numbers, we gain in power and in prestige. 
As soon as the demoralized rulers will see the signs of the time and come to know our power they will court us and make friends. Those people are not the barbarians they would like to appear.

And now I must apologize to my readers for having occupied their time more with Biedermann than with Philosophy; they belong, however, insofar to the same category as they are both to be informed that we must not speculate in hazy generalities, but that we must inquire in a definite, precise and special manner into the material at hand in order to arrive at truth.

IV.

In the foregoing chapters we have represented Philosophy as the descendant of Religion and like it, though somewhat more respectable, as a fantastic speculator. To "solve the riddle of existence" - is the subjectmatter of those two madcaps.

The philosophers give their subject-matter various pompous titles. We have already seen that Herr von Kirchmann calls it "the science of the highest conceptions of existence and knowledge." The famous Kant defines it as "God, Freedom and Immortality." In more recent times Dühring defined it as "the development of the highest form of consciousness of the world and life" (Kursus der Philosophie von Dr. E. Dühring, Leipzig, 1875 , p. 2). "Highest form of consciousness" is scientific knowledge, and the " evolution" thereof is performed by researches. According to that we ought to define Philosophy as the scientific exploration of the world and life.

But if one speaks in such a common-sense way the faculty of Philosophy loses its halo, moreover it becomes 
quite superfluous, for such an investigation is carried on successfully by the special branches of science. It seems that Dühring felt the uselessness of his philosophic guild, for he ascribes to it also the function of " practical activity." Philosophy has thus not only the task to conceive world and life in a scientific manner, but to demonstrate that conception through the character and actions of its adherents. That way leads to Social-Democracy. Having advanced so far, the philosopher may, perhaps, get a deeper insight into things and do away with Philosophy altogether. To be sure no man can do without some conception of world and life, but that of Philosophy is of a kind which is utterly useless. Its wisdom is an intermediate stage between religion and science. The creation story of the Holy Books is too childish for the philosopher, and the airy, fact-removed and purely mindborn philosophical sommersaults are too fantastic for science. We said before the method is the distinguishing feature between religion, philosophy and science. All three look for wisdom. The method of religion is to look for wisdom on the Mount Sinai behind clouds or among ghosts. Philosophy applies itself to the human mind, but as long as the mind itself is befogged by religious mists, it asks and functions in a perverted manner, that is, without real premises, in a speculative way or in hazy generalities. The method of exact science operates with the material of the perceptible world of phenomena. As soon as we learn to know that method as the only rational one of the intellect, all fantasms are at an end.

If this disquisition happens to come under the eye of a professional philosopher he will surely sneer at it, and if he condescends to reply to it he will try to explain that the men of the special sciences are uncritical materialists who accept the perceptible world of experience without 
further examination into its truth. And as to his operating without any real premises he will refer you to the many pranks and delusions of the senses which lead us often into errors. Therefore he asks: What is truth and how do we arrive at it?

Right he is. Truth is a great question. It is, especially for Social-Democrats, an interesting question. In the domain of natural science all ghost-seeing has been removed by a rational method. But in social life, where we have to deal with masters and servants, with labor and its produce, with right, duty, law, morality and order, there the parson and the professor of Philosophy are still regarded as authorities and each of them has his special method to mask truth. Religion and Philosophy, once harmless errors, have now been turned into crafty tricks to bamboozle the people and to serve the interests of reaction.

From the lesson given in the preceeding article by Professor Biedermann we have learned that it is futile to put any question in an indefinite and hazy manner. In this respect Philosophy has put itself in opposition to sound common sense. For it does not seek, like the special branches of science, for definite empirical truths, but it seeks, like religion, for an extraordinary sort of truth, for an absolute, unreal and exaggerated one. What everybody thinks to be true, what we see, hear, feel, taste and smell, in short, our bodily sensations, do not commend themselves to Philosophy as sufficiently true. Natural phenomena are in its eyes only appearances or semblances, and she refuses to have anything to do with them. That Philosophy treats Nature with disdain, it dare not admit, because natural science has gained in the last hundred years a reputation which cannot be gainsaid. It is none the less certain that Philosophy seeks 
for a truth which is not to be found in Nature. Philosophic truth that can nowhere be traced must surely have an aroma of its own, and belong to a species totally different from the natural. It is just that the philosopher labors under religious delusions and wants to go beyond all natural phenomena and looks behind this world of phenomena for another world of truth by which the first could be explained - because of all that, I say, he has taken refuge in a method without any really given premises, which tries to weave thoughts into definite materials, or, in other words, blunders about in hazy generalities. Descartes is supposed to have discovered a tiny bit of that transcendental truth; it is at least that bit on which Philosophy has been living ever since. The parson's truth, the passive belief, which was then current, did not satisfy the philosopher. He began to make enquiries with the doubt which he exercised to such a degree that he doubted everything which is visible and audible. But he noticed that one thing was certain to him, viz., the bodily sensation of his own doubt. He, therefore, put forward the proposition: Cogito, ergo sum ( $\mathrm{I}$ am thinking, therefore do I exist). Since then it has been impossible for his successors to rid themselves of their exaggerated doubtfulness and of their quests after exaggerated truth.

Far be it from me to refuse to recognize the historic importance and the keenness of mind of that famous sceptic. He was right; the bodily sensation of existence, my consciousness, my thinking, feeling, in short, "my soul " is, as the parson says, beyond doubt. Yet I must add, that I am ascribing to Descartes much more than he really achieved. It is like this, the philosopher had two souls, a traditionally religious and a scientific one. His philosophy has a mixture of both. Religion deluded him into 
believing that the perceptible world was unreal, whilst his scientific cross-current tried to imbue him with the conviction that the opposite was true. With the unreality, with the doubt he started out and with the statement of his bodily sensation of existence he proved the opposite. Yet the scientific cross-current did not succeed in gaining a full and final victory. It is only the impartial enquirer who, when repeating the experiment of Descartes, finds out that it is the bodily sensation which gives us certainty of the existence of the process of thought when ideas and doubts are moving about in the head. The philosopher turned the thing upside down, he wanted to prove the bodily existence of the abstract thought - he assumed to be able to prove scientifically the exaggerated truth of a religious or philosophic soul, while in reality he has only confirmed the common truth that bodily sensation exists. The sensation of profane existence Descartes mistook for a proof of the existence of a higher being. His misfortune is the general misfortune of all philosophy: to be purely idealistic and spellbound.

I am introducing the readers of the Volksstaat to a subject-matter which they might consider too subtle. But we must make proselytes also among the scholars. So we must prove that we are well informed about "the last causes" of all things, and that our cause has its foundations laid in the deepest depths. We must make short work also of the philosophic bombast. Pure idealists! A clear-headed workingman, when coming to know them, will hardly think it possible that there are such foolish fellows. Idealists in the proper sense of the word are all aspiring men. All the more so the Social-Democrats. Our aim is a grand ideal. But the idealists in the philosophic sense are an irresponsible lot. 
They assert that everything we see, hear, feel, etc., that the whole world around us does not exist, but are simply flashes of our mind. They assert that our intellect is the only truth, everything else is an idea, a phantasmagory, a mirage, an appearance in the purely ideological sense of the word. Everything which we perceive of the external world, they say, is not an objective truth, not a real thing, but only a subjective drift of our intellect. And when common sense refuses to accept such an assumption they will in a plausible manner demonstrate and tell you that although you see every day the sun rising in the East and setting in the West, yet science teaches quite differently and you must have recourse to science in order that you may be able to use your senses intelligently.

Also a blind hen, says the proverb, finds sometimes a good grain. Such a blind hen is philosophic idealism. That the things which we see, hear or feel are not objects pure and simple, is its good grain. Also scientific physiology comes more and more to the conclusion that the various-colored objects which our eyes see, are sensations of our optic nerve, that all the crude, fine and heavy which we feel, are sensations of heavy, fine and crude. Between our subjective sensations and the objective things no absolute line can be drawn. The world is our perceptible world, that is, as perceived by our senses. Without eyes the objects would have no aspect whatsoever, and without a nose they would have nothing of an odor. "There is no noise without ears to hear it, and no heat and cold without a skin to feel it," said Professor W. Preyer in Jena in one of his latest articles on the "Limits of sense perception." The things of the world do not exist " in themselves," but they possess their properties only by their relation to each other. It is in 
relation with sunlight and our optic nerve that the forest appears green. With another light and with a different optic nerve they might appear blue or red. Water is only liquid in relation to a certain temperature, in a low temperature water becomes hard and solid, in a high temperature it turns into gas; it generally runs downhill, but when in touch with a loaf of sugar it runs upwards. It has no properties or existence in itself, but gets them by relation to other things. As with the water so it is with all other things. Everything is but the quality or predicate of Nature which is nowhere to be found in a transcendental objectivity or Truth, but is always round us in fleeting and form-changing appearances.

The questions as to how the world would look if there were no eyes, no sun, no space, no temperature or intellect or sensation, are idle, and fools may investigate them. No doubt, in science as well as in life we are allowed to differentiate, to distinguish and to classify ad infinitum, but in doing that we must never forget that all things form a single unity and a connected whole. The world is a world of senses, and our senses and our intellect are worldly. This is by no means a "limitation" to man, but to those distracted ideologists who want to go beyond Nature. When we demonstrate that the immortal soul of the parson or the undoubted intellect of the philosopher are of the same common Nature as are all the other phenomena of the world, then we have proved that the other phenomena are as real and true as the undoubted intellect of Descartes. We not only believe, assume, think that our sensation has existence, but we feel it truly and really. And conversely: The whole truth and reality is based on feeling, on bodily sensation. Soul and body, or subject and object as the old 
joke is called by its modern name, are of the same earthly, perceptible, empirical stuff.

"Life is a dream," said the ancients. Now the philosophers come with the latest: "The world is our Idea." Yes, but this Idea is not an absolute or transcendental Truth. It is quite sufficient when we distinguish the great, general and true dream in daylight from the more or less unconscious dreaming over night and in the dark, since in so doing we finish with pure Idealism which is the weakest and most shortcoming part of Philosophy.

To base truth not on the word of God and not on traditional principles, but our principles on bodily sensations - that is the cardinal point of social-democratic philosophy.

\section{V.}

"God formed the human body out of a clod of clay and breathed into it an immortal soul." Since that time we have the dualism or the two-world theory. The one, the bodily, the material world is dirt, and the other, the spiritual or mental ghost-world is God's breath. That little story has been secularized by Philosophy, that is, adapted to the $Z$ eitgeist. The visible, audible and tangible, the bodily reality is still regarded as dirty clay, while to the thinking mind is given the kingdom of a transcendental Truth, Beauty and Freedom. Just as the world has a bad name in the Bible, so also in Philosophy. Among all phenomena or objects which Nature offers, Philosophy finds only one object worthy of attention, namely, the mind, the old breath of God; and that only because it appears to those queer heads as a transcendental, unnatural, metaphysical thing. It is surely permitted to the inquirer to limit himself to one object, but he must not deify it, nor tear it from its interconnection, 
nor worship it in an exaggerated manner. The philoso pher who approaches the human mind soberly and make it the aim of his inquiries, like any other object of the many objects in the world, ceases to be a philosopher, that is, one of those who want to study the riddle of existence in a general, hazy, manner. He becomes a specialist and the special science of the theory of cognition becomes his special branch of inquiry.

Because Philosophy regarded all special objects of the world as dirty and material, nothing remained to it but the hazy speculation in indefinite, misty generalities. The philosophers possess, however, along with the religious soul, an exact Reason with a scientific tendency, a Reason which wants to achieve something definite. They are, therefore, compelled to look out for a definite object, for a scientific specialty. The logic of reality has driven Philosophy to become and to undertake something which it didn't want to become or to undertake. The reasonable desire for success in connection with the traditional worship of the divine breath gave thus to Philosophy as its object of inquiry the matter-of-fact Intellect.

That the common spirit of the human head is their true spirit, the philosophers hardly know; this must be made clear to them by Social-Democrats. The philosophers, as a rule university professors, have an interest in preserving for their professional intellect the character of the divine spark. All the more must it be the interest of the working men to know that this very intellect is a common natural object. Behind the question as to whether there is in our head a sublime idealistic spirit or a common human reason, we find the great social question hidden as to whether might and right are to-day on the side of the privileged class or on the side of the common people. 
Struggle of the good against evil is the eternal essence of history. Sometimes the struggle reaches an acute stage, as for instance to-day when the productive working class is struggling against the ruling parasite class. In this struggle a good many splinters are thrown about. Everything is affected by it; even the language is going to pieces. The "highest" conceptions, such as Truth, Freedom, Culture, are being corrupted. "Philosophy" and "seats of learning" must be put in inverted commas in order to mark the equivocal character which they have assumed. Professors have become generals in the army of evil. On the right wing are in command Treitschke, in the centre von Siebel, on the left wing Jürgen Bona Meyer, doctor and professor of Philosophy in Bonn. The latter delivered lately in the Berlin " Gegenwart," a logomachy against the "Unbelief of our Times," against the religion of Social-Democracy. He leads the crack regiments of his "science," the labored points of philosophic Idealism, into battle, and he comes just in time to be captured with his war materials in order to enable us to illustrate by them to the students of social-democratic Philosophy our subject-matter.

In the foregoing chapter we have already mentioned the feat of Descartes which the professors of higher magics or Philosophy are in the habit of producing before the public in order to dupe them. They try to demonstrate the breath of God as truth. To be sure that name fell into disrepute, and enlightened, liberal-minded people do not talk any more of the immortal soul. Instead of that they talk in a sober, materialist way of consciousness, faculty of thought and ideas. But to represent it as having a common non-transcendental nature, no enlightened man, even of the liberal class, would dare to do. It is only the Social agitator who represents it like that. To 
Jürgen Bona Meyer and Co., to the doctors of Philosophy, it is a foregone conclusion, a dogma, that the human mind is of a transcendental nature. Let us have a look at that dogma.

We feel in ourselves the bodily existence of thinking Reason, and with the same sensation we feel outside ourselves the clods of clay, the trees and shrubs. And that which we feel inside, and that which we feel outside ourselves are not far removed from each other. Both belong to the category of perceptible phenomena, of empiric material, and both become known to us through sensation. How to distinguish subjective from objective sensations, the inside from the outside, Ioo real dollars from 100 imaginary ones - of that we shall speak upon occasion. Here it is only necessary to grasp that the inner thought, like the inner pain, exists as objectively as the outside world exists subjectively in relation to our organs of sensation. The relation between subject and object, spirit and Nature, thought and existence, which has puzzled so many people, becomes clear when we gain the understanding that the opposition is but a relative one, that these opposites differ only in degrees.

It is the democratic equality of all things in Nature, of the body and the soul, which cannot enter the heads of the "philosophers." The said Meyer with his science without any given premises starts really from the supposition that the breath of God or the immortal soul or the philosophic intellect is of a higher and more direct Truth than any other children of the common mother Nature. As long as he does not relinquish that idea it is easy to prove that the "external world" is of mere clay, and that its existence does not rest on science, but on belief.

Let Jürgen speak for himself: "The man who is a 
non-believer on principle must again and again be referred to the truth proved philosophically that all our knowledge rests in the last resort on some sort of belief. Even the materialist accepts the existence of the world as a matter of belief. He does not possess a direct knowledge of it; he is only sure of the idea of the world which arises in his mind; he believes that there is something which corresponds with his idea, that the represented world is such as he imagines it to be; he does believe in the existence of an external world on the evidence of his mind. His belief in the external world is primarily a belief in his own mind. And why does he believe that the imagined world will be such as the human mind imagines it or must imagine it?- $\mathrm{Be}-$ cause it would be irrational to assume that the human mind which has the impulse and the power to imagine an external world, would necessarily be deceived in the exercise of its power. . . . Thus the belief in the senses is in the last resort a belief in the fitness of our mind. The preconceived notion of the fitness of the world forms thus the last basis of the materialistic conception."

There you have the feat of Descartes in a new and cheaper edition. "Only the idea is undoubtedly certain," but also this certainty is uncertain, for he speaks of "the belief in one's own mind." Meyer's belief is "philosophically demonstrated," yet he knows that he knows nothing, that all is merely belief. He is modest with regard to knowledge and science, but overconfident with regard to belief and religion. Science and belief are used by him in a confused manner, maybe that he does not attach any importance to either of them.

Ncw it is "philosophically demonstrated" that all our knowledge is done for. For the benefit of the reader I may add that the guild of Philosophers at their last 
general meeting in all solemnity carried a resolution to purge our language from the word "science," and to put belief in its stead. All knowledge is henceforth merely a believing. All knowledge is now at an end. Sure enough, Jürgen speaks of "direct certainty" and "philosophically proved truth ;" but that is simply an unconscious relapse into the bad manners of old. Or, maybe, he uses the words like the theologians who regard the mother of Jesus with her eternal virginity, or the talking ass of Balaam as a " demonstrated truth" and " direct certainty." The Professor, however, corrects himself, for he says explicitly: the belief in the perceptible world is a belief in one's own mind. Thus everything, spirit and Nature, rests on belief. But, alas, he is surely wrong in trying to impose upon us dialectic-materialists the resolution of his guild. For us the resolution is not binding. We remain true to the use of the language in reserving to ourselves knowledge, and in surrendering all mere believing to the parsons and Doctors of Philosophy.

No doubt "all our knowledge" rests on subjectivity. The wall yonder, against which we could split our heads and find it, therefore, impenetrable, may be passable like mere air for goblins, angels, demons and other ghosts, or for such people who deny the whole dirty clay of the perceptible world-but what of that? Why bother about a world which we can't perceive? Maybe, that what people call fog and wind are really, purely or " in themselves," heavenly flutes and counterbasses. But for all that we can have nothing to do with that transcendental moonshine. Social-democratic materialists deal only with things which man perceives empirically. To those things also belongs his own faculty of thinking. The empirical we call truth, and only that do we make 
an object of science. If Professor Jürgen Bona Meyer and the pure Idealists want to introduce a perverted nomenclature, to give science the name of belief and priestcraft the name of science, then it becomes evident to a good many people that the official Philosophy has turned from a devotee to a servile " menial of the Lord."

Since Kant made the critique of Reason a specialty of philosophic research we know that the five senses are not alone sufficient to gain experience, but that the intellect must co-operate to that end. The critique of Reason has also taught us that the divine spark can only become active in the material domain, that is, in the empirical world; that Reason without the help of the senses has no sense or understanding, and is therefore a thing of common relationship with all other things. Yet the great philosopher found it too difficult to forget the story of the divinely inspired clod of clay so as to liberate the mind from its ghostly effect and to consummate the emancipation of science from religion. The conception of the disdainful, clay-like matter and of the "thing in itself " or the transcendental truth enveloped all philosophers more or less in a purely idealistic delusion which solely rests on the belief in the metaphysical character of the human mind.

That weak spot of our great critic is now taken advantage of by our Prussian and Imperial philosophers in order to make out of it a new religious idol, and a wretched one to boot. "The idealistic belief in God," says J. B. Meyer in the above mentioned article, "is surely not knowledge and will never become such, but it is likewise sure that the materialist's unbelief is not knowledge, but a materialist belief which can no more become knowledge than the idealistic belief." The metaphysical craving of our philosopher would be quite satis- 
fied if the Social-Democrats would but confess that they understand as little of the question, or that they are as much in the dark about their basic principles as Meyer is about his. He wouldn't perhaps mind atheism; it is the Social-Democratic self-consciousness which he can't stand - the self-consciousness which turns even against the thin, consumptive belief of the Prussian and Imperial philosophers. "All religious belief," continues Meyer, "begins with some exaggeration, with some fallacy, and needs, therefore, constant cutting of its false excrescences. . . . The progress of belief consists just in this, that through the increase of knowledge, belief rids itself of superstition." But he forgets to inform us about that true philosophic miracle of a religion free from superstition which is to remain despite the "constant cuttings." He goes on angrily: "The popular champions of the materialistic and atheistic unbelief are with few exceptions not leaders of science, but misguided braggarts of knowledge." Well, dear Jürgen, they do not at all claim the leadership of general science, but are limiting themselves to the study of a specialty, namely, to the theory of cognition, in order to be able to send the parsons of Philosophy about their business.

\section{VI.}

The philosophic apologies of Jürgen Bona Meyer, quoted in the last chapter, are the last make-shifts of religion. And it isn't he alone who plays this tune. He has with him in the literature of the day a whole company of musicians who are in the same boat. All of them repeat the same reactionary refrain: "Back to Kant." The question has therefore an importance which goes beyond the little person of General Jürgen. They 
do not want to go back to Kant because this great thinker has made short work of the story of the immortal soul that he has undoubtedly done; but they would like to return to him, because he, on the other hand, has left in his system a narrow entrance through which a little metaphysics can be smuggled back into it - that he has undoubtedly done, too.

Idolatry, Religion and Philosophy are three slightly different kinds of the same thing, which is called metaphysics or cracked Truth. I apologize for the use of the latter adjective, but an unequivocal characterization demands a strong terminology. The cracked Truth has played a great part in the history of the world. Idolatry, Religion and Philosophy have been evolved from one another in the course of time; and now, in the time of Social-Democracy, we have arrived at the point when Philosophy, the "last Mohican" of the metaphysical tribe, must be transformed into rational Physics.

It is clear: all perverted wisdom rests on the perverted use of our intellect. And nobody has been more successfully and courageously engaged in the inquiry of the intellect and in the foundation of the theory of cognition than Immanuel Kant. Still, there is an essential difference between him and his successors of to-day. In the great historic struggle against superstition he stood on the side of progress; he put his genius into the service of the revolutionary development of science, while our Prussian philosophers serve reactionary politics.

As long as the philosophers were sometimes in danger of being sentenced to take poison, like Socrates, or of ending their life on the stake, like Giordano Bruno, of being expelled by the Prussians and threatened with the gallows, like Wolf, or of being placed under Police supervision, like Kant and Fichte - in short. as long as 
Philosophy was a dangerous occupation, it was also an honest endeavor to struggle through the mists of metaphysics to Reason, to rational thinking. Now, however, when philosophers have given up the struggle and are sounding retreat, it is time for Social-Democracy to learn with what kind of "science" and with what sort of "liberal" fellows they have to deal.

The push with which Kant has thrown metaphysics out of the Temple, and the narrow back door which he left open are clearly indicated in a few sentences in the preface of the second edition to his "Critique of Pure Reason." Not having the volume at hand, I quote from memory. They are as follows: Our knowledge is limited to the experienced things, to the phenomena; what they are in themselves we are not able to know. Yet, the things must be something in themselves, else we would arrive at the inconsistent proposition, that appearance exists without the something which appears.

The great thinker argued seemingly quite logically, and yet his argument is altogether faulty. On his fal. lacy rests the metaphysical remains which Philosophy still drags along.

It cannot be denied that where there are appearances there is also something which appears. But how would it be if that something were the appearance itself, when appearances simply appear? There would be nothing illogical or irrational in that, if subject and predicate were everywhere in Nature of the same kind. Why should the something which appears be of a quality totally different from the appearance? Why can the things "for us" and the things "in themselves"- why can appearance and truth not be of the same empirical material, of the same Nature?

Reply: Because the superstition about the metaphys- 
ical world - because the belief in the dirty clay, which is evident, and the belief in an imperceptible exaggerated or divine truth, which must somewhere dwell in it, has not been cleared completely out of Kant's mind. The syllogism: Where there are appearances which we see, hear and feel, there must also be concealed in them something quite different, a so-called higher or divine Truth which cannot be seen, heard or felt - this syllogism is a fallacy despite Kant.

The scholastic squabble about God, Freedom and Immortality was repulsive to that thinker. Therefore he put the intellect to the test and asked, whether something cracked, or metaphysics, could be possible as a science. No, was his reply after a wonderfully clear and thorough inquiry. No, our instrument of cognition depends on experience as well as our experience on that instrument. In other words, our mind cannot produce science but with the help of perceptible material, and science must and can have nothing to do with the "other world." Only in its conscious connection with the materialist experience may the intellect become operative, and all questioning into hazy generalities can lead only to confusion and failure.

But the Königsberg Professor had, as Heine relates, a valet, a common fellow of the people, by the name of Lampe, to whom, it is said, air castles were an emotional necessity. The Professor took pity on him and argued: whereas the world of experience is closely connected with the intellect, we have really nothing else but mental experiences, that is, mental appearances or flashes. Empirical material things are no real truths, but apparitions in the transcendental sense of the word, cobwebs of the mind or something like it. The real things "in themselves," the metaphysical truths, are beyond our experi- 
ence, and must therefore be believed, in consequence of the well-known argument: Where there is appearance there must be something (metaphysical) which appears.

Thus was the belief, thus was the cracked truth snatched from the fire of rational inquiry, which was very welcome, not only to the valet Lampe, but also to the German Professors in the "Kulturkampf," for "popular enlightment" and against the hated and radically unbelieving Social-Democrats. Immanuel Kant was henceforth the proper man; he helped them to attain the requisite, though not scientific, balance of mental attitude.

The theologians are now no more in need of telling us how the old Lord Zebaoth looks, in how many choirs the angels are divided, and in how many regiments the devils, or whether the commanders are called Gabriel, Michael or Lucifer - for Kant's philosophy has proved once for all that nothing can be known about them, and that, therefore, the parson must shut up.

But when the Social-Democrats appear on the scene and rejoice over the good news that superstition has disappeared and that the cracked hopes have ceased troubling, and that the earthly salvation has begun, then - of course, things look different, then they will preve to you by the same Kant that, though we cannot see, hear or perceive the metaphysical truth which dwells behind the natural phenomena, we must believe in it. Thus we cannot get rid of belief, if not in Rome, and if not in the Bible, then in the "Back to Kant," Jürgen Bona Meyer and his ilk.

The Social-Democrats are convinced that the clerical Jesuits are less dangerous than the "Liberal" ones. Of all parties the party of the middle-roaders is the most wretched. It uses the terms Enlightenment and Democracy as a false label in order to offer to the peo- 
ple adulterated goods and to discredit the genuine ones. They, of course, offer their goods on their best knowledge and conscience. And we do believe that they know little; but the worst of it is that they don't want to know and don't want to learn. The superstition is with them not as much a matter of brains as of instinct. They are alarmed at ghost-freed thought, for they feel instinctively that it is dangerous to their interests. And it is that instinctive fear which paralyzes them and renders them unfit for courageous and consistent research.

Under such circumstances it would be a mistake to treat them as equals, to meet them in a friendly spirit and to try to bring them back on the right path. They are by no means stray lambs, but bitter foes. Since Kant a century has gone; Hegel and Feuerbach have come and gone, and before all, the capitalist system has fully developed which exploits the people and, finally, when no profits can be made out of them, throws them pitilessly on the street and leaves them to starvation. Then the people open their innocent eyes. All ideology is driven out of them, and thus we need no tender pedagogues, nor Moses and the Prophets to educate the masses. Our pupils, the wage-earners, possess all qualifications necessary to gain an insight into the Social-Democratic Philosophy, which regards the natural phenomena as the material for theoretical or scientific truth, the empirical and materialist, or, if you like, also subjective truth, which, however, must be clearly distinguished from the extravagant or cracked truth of metaphysics.

Just as in politics we see the nation dividing itself into two camps, on one side the wage-earners and on the other the capitalists, corresponding with the economic development which is thinning the ranks of the middle classes and leaving only two classes: the Have and the 
Have-not, so is science divided in two general divisions: into metaphysicians there and into physicists or materialists here. The intermediate members and conciliating quacks with their different appellations: Spiritualists, Sensualists, Realists, etc., etc., fall underway into the current. We are steering full steam ahead to a definite and clear outline of things. Pure Idealists are those who sound the retreat, and dialectic Materialists must be the appellation of all those who strive for the liberation of the human mind from all metaphysical magics. In order that names and definitions may not confuse us we must steadily keep in mind that the general want of clearness has not allowed yet of establishing a distinct terminology in this field.

In comparing the two parties with solid and liquid matter we find pulpiness as the intermediate stage. Such indistinctness is the general nature of all things in the world. It is only the faculty of cognition, or science, which clears them and puts them asunder, just as it has distinguished heat from cold by inventing a thermometer and agreed to regard the freezing point as the fixed limit where the indistinct temperature is divided into two different classes. The interest of Social-Democracy demands that we should apply the same process to Philosophy, that we divide the general species of thought into two classes: into purely idealistic, religious, emotional twaddle and into a sober, inductive or materialist methor of thinking.

\section{VII.}

This series of lectures, published in the Valksstaat, have been temporarily interrupted. I shall not speak of the reasons which led to the interruptions, but let me 
simply say that I am going to continue them, or rather start them anew.

Dialectically speaking, the continuation of the old is at the same time a fresh start, especially in our subjectmatter, for the social-democratic conception of the world is a complete system which, in the form of an inverted pyramid, moves, like a whipping-top, on its point. And as the whipping-top spins only in connection with its broad head and with its level plane and with its string which sets it in motion, so can the point of our new, systematic conception of the world not be represented in an isolated manner in itself, but only in the closest connection with the manifold questions which agitate the world. This subject-matter, " the fixed pole in the ceaseless motion of events," needs thus continuous variations in order to go on with the old continuation by a fresh start.

Though we Social-Democrats are atheists without religion, we are not irreligious, that is, the gulf between us and the religions is great and deep, but has, like other gulfs, its bridge. It is my intention to lead the socialdemocratic comrades to that bridge and to show them from there the difference between the wilderness in which the believers are wandering about and the promised land of serenity and truth.

The supreme commandment of the Christian is: Thou shalt love God beyond everything and thy neighbor as thyself. Well, God beyond everything. But who is God? $\mathrm{He}$ is the beginning and the end, the Creator of Heaven and earth. We don't believe in his existence, and yet we find something reasonable in the command which orders us to love him beyond everything.

Those who contemplate the Eternal, Omnipresent and 
Most Honored cannot fail to perceive that $\mathrm{He}$ is in reality nothing else but the personification of the Universe; no mortal can claim nowadays to have seen the All-Father and to have spoken to him. Yet the atheists, too, must acknowledge that reason-gifted man is, despite his intellect and his science, a subordinate creature, dependent on sun and winds, earth, fire, air and water. That means that our mind, destined though it is to rule over matter, is none the less a limited ruler.

With our intellect we can rule in a formal manner only. On a small scale we are able to control the changes and movements of matter according to our will, but taken as a whole, as the substance of things, cosmic matter is superior to all mental capabilities. Science is able to transform mechanical energy into heat, electricity, light, chemical energy, etc., and it may succeed in transforming all phenomena of matter and of force into one another and to reduce all its forms to one element; but all this granted, science can only change the form, while the essence remains eternal, imperishable and indestructible, a given material. The intellect can get out of matter the secret of its physical changes, but they are after all material ways which the proud intellect can only follow but not command. Sound thinking must always be conscious of the fact that it is, together with the "immortal soul" and the knowledge-proud reason, only a subordinate piece of the Universe, though our present "philosophers" are still occupied with the jugglery of transforming the real world into an "idea" of man. The religious commandment: Thou shalt love God beyond everything, means in plain social-democratic language: Thou shalt love and honor the material world, the corporeal Nature or the perceptible existence as the final cause of all things, as the Existence without a begin- 
ning and an end, which was, is and will be from eternity to eternity.

As it is well known and as we have repeatedly stated, the philosophers are a more or less progressive offshoot of the theologians and doctors of divinity. All of them are, consciously or unconsciously, "one reactionary mass," that is, their common characteristics are to be found in the fact that they regard the Universe as the product of the Intellect, while we regard the Intellect and all other forces, like heat, gravitation and all which is audible, visible and tangible, as a form or species, as a piece or product of the general force, which is identical with the omnipresent, eternal and indestructible cosmic matter. Language has so far treated the conception of force and matter rather arbitrarily. Palpable things like wood, stone, clay, etc., are ponderable forces, while those things which we cannot touch with our hands, for instance, light, heat, tunes, we call imponderable matter. The world of tunes constitutes the matter of the musician. And those who dislike this generalization of the word "matter" may, instead of that, speak of "phenomena." Bodily, physical, perceptible, material phenomenon is the name of the general species, to which everything belongs, the ponderable and the imponderable, body and soul.

In order to clear ourselves of the "metaphysical craving" it is absolutely necessary to keep in mind that al! differences which we may make are but the manifold forms or the attributes of one indivisible unity. Though we differentiate between the bodily and the mental forms, the difference is none the less but a relative one; they are but two kinds of one and the same existence. This difference is no greater than that between cat and dog, who, regardless of their well-known animosity, belong 
to the same class or species, namely, to that of domestic animals.

Natural science in its narrower sense cannot give us the monistic conception of the world (that is, unity of $\mathrm{Na}$ ture : unity of matter and mind, of the organic and inorganic, etc.) which is so eagerly looked for in our time, even if science succeed in proving satisfactorily the origin of species and the evolution of the organic from the inorganic. Science achieves all its discoveries through the intellect. The visible, tangible and ponderable part of that organ undoubtedly belongs to the domain of natural science; but the function, the thinking, is investigated by a separate science which some call Logic, or Epistemology or Dialectics. The latter department of science, the understanding or misunderstanding of the mental function, is the common ground of religion, metaphysics and the anti-metaphysical investigation. Here the bridge is to be found which leads from servile, superstitious oppression to modest freedom. Also in the democracy of epistemological freedom modesty governs, that is, submission to material, physical necessity.

The inevitable religion changes in the heads of the philosophers into metaphysics, and in the heads of clear thinkers into the undeniable necessity of a monistic conception of the world. The existing matter-force, also called Universe or Existence, becomes mystified in the heads of the theologians and philosophers, because they do not understand that matter and mind are of the same species, and because they pervert the relation in which they stand to each other. Materialism is, like Political Economy, a scientific, a historical result. Just as we distinguish between modern and utopian socialism, so also between modern and $\mathrm{I} 8$ th century materialism. With the latter we have only this in common that we assume 
matter as the premise, as the cause of the idea. Cosmic matter is to us the substance, while mind is the incidence; the empirical phenomenon is to us the species, and the intellect but a variety or form of it, while all religious and philosophic idealists assume the idea to be the primary, the causative and the substantive force.

What we see, hear, feel, etc., say the idealists, are the intellectual phenomena, insofar as the intellect must exist where things are to be seen, heard and felt. Good and well, say their opponents, but with it there is also matter. Where there is intellect, thinking, consciousness and knowledge, there must be an object, too, a matter which is perceived, and that is the main thing. What is the main thing, matter or mind? That is the old question which separates idealists from materialists. But that question, too, is but a piece of hazy phraseology. The real difference between the two camps is that the one turns the Universe into witchery, while the other camp will have nothing to do with that. All natural phenomena being only perceptible with the aid of our intellect, all our perceptions are intellectual phenomena. Quite so. But in that sum total is included a special sensation, a phenomenon, which especially deserves the adjective " intellectual," and that is human reason, mind or the faculty of forming ideas, while the other phenomena are collectively called material. Therefore it really comes to this: matter, force and intellect are of the same origin. It is indeed a miserable logomachy to quarrel about the adjectives "intellectual" and "material." The main thing is to know whether all things are of the same species or whether the Universe is to be divided in a supernatural, mysterious witchery and a natural, ordinary clay.

Those who desire to gain a clear notion about that must not be satisfied with simply following the example 
of the old materialist who reduced everything to ponderable atoms. Cosmic matter has not only gravity, but aroma, light and sound - and why not also intelligence? If the smellible, visible and audible is more spiritual than the ponderable - if the comparative is natural, why not also the superlative? Gravity cannot be seen nor light be smelled, nor the intellect be touched, but we may perceive everything which exists. Don't we perceive our thoughts as physically as we feel pain, light, heat or stones? The prejudice that ponderable objects are more perceptible than the phenomena which are communicated to us through hearing or feeling in general misled the old materialists to their atomistic speculations, misled them to make the ponderable the final cause of things. The conception of matter must be given a more comprehensive meaning. To it belong all phenomena of reality, also our force of thinking. To the idealists who call all natural phenomena "Ideas" or "intellectual phenomena" we say that the natural phenomena are by no means "things in themselves," but objects of our sensations. Since also the particular phenomenon called subjective feeling, soul or consciousness is an object of sensation, there is no use here splitting up things into subjective and objective. The objective thing can only be perceived subjectively, and vice versa. Both exist and both are of the same kind; body and soul are of the same empirical material. An impartial observer can have no doubt that spiritual material, or, to be more exact, that the phenomenon of our force of thinking is a part of the world and not the reverse. The whole governs the part, cosmic matter the mind, at least in the main, though it is true that mind reacts on cosmic matter. And it is in this sense that I said we must love and honor the mate- 
rial world as the supreme being, as the cause of all causes, as the creator of heaven and earth.

That confession does not in the least prevent us from regarding the intellect as the primus inter pares, as the first object of all the objects in the world.

When Social-Democrats call themselves materialists, they only want to emphasize their view that they refuse to acknowledge anything which pretends to lie beyond human cognition in a metaphysical way. All witchery must go overboard.

But - so do our philosophical ravens croak - what about "the limits of natural cognition?" Has not the learned Du-Bois-Reymond proved conclusively that the haughty intellect has its limits? And has not our late socialist friend, F. A. Lange, the expert historian of Materialism, agreed to all that and expressly declared that all our knowledge could not penetrate the essence of things, and that, after all, something mystical and inconceivable must remain unsolved forever?

That theory of the limited understanding of common humanity is a fool's theory, which we shall still further discuss. 


\section{THE LIMITS OF COGNITION.}

(VoRWÄrTS, 1877)

An anonymous letter touching the above subject, written evidently by an expert, has recently been received by the Vorwärts, which in an unbiased manner attempts to show that Philosophy and Social-Democracy are two things apart and that, therefore, one may very well belong to our party without adhering to the "Social-Democratic Philosophy." Hence it is concluded that the central organ of the party was wrong in allowing philosophic discussion to become a party matter.

The editor of the Vorwärts has been good enough to show me that letter as it referred to my articles. Though the author has given clearly to understand that he had no wish to provoke by his protest any public controversy, since, as he maintains, newspaper controversies did not admit of a thorough treatment of the subject, nevertheless I hope he will not find it indiscreet if his objections are used here for the purpose of elucidating a question which both to him and to myself and, to judge from the general interest displayed at present with regard to it, appears to be of great importance to our whole generation. And as regards thoroughness, it seems to me that voluminous books are no better qualified for it than newspaper articles. On the contrary, there has been of late so much longwinded twaddle that a great portion of the public is losing all taste for the discussion of such matters. 
First of all I should like to contradict the statement that Philosophy and Social-Democracy were two things apart which had nothing between them in common. Quite true, one may be an efficient member of the party and at the same time a "critical philosopher," or even a Christian. The human soul is such a queer thing that it can easily find some sort of conciliation between the veriest contradictions. And not only in things philosophical and religious, but also in things economical, a great measure of heresy is permitted. We must in practice be tolerant to the extreme, and surely no Social-Democrat would ever think of putting any Party member into the straightjacket of uniformity. Nevertheless, theoretical uniformity must be demanded of all who devote themselves to scientific investigation. Theoretical uniformity, systematic homogeneity is the consummation to be desired as well as the advantage of all science. That Social-Democracy is scientific and science is social-democratic will, I hope, be granted by my esteemed opponent. Of course, there are many branches of science which bear less on the socialistic aspirations to emancipate enslaved humanity. But the philosophical question - the question whether there is beyond and above the world anything metaphysical, " anything higher," which it would be too monstrous for our intellect to attempt to conceive, or which is beyond the human understanding to explain - this special question of Philosophy about the "Limits of Cognition" bears very closely upon the slavery of the people.

Social-Demosracy does not seek to establish eternai laws, permanent institutions or unchangeable forms; it seeks in general the salvation of mankind. The indispensable mears toward attaining that object is mental anightenmexit. The question whether the instrument of 
cognition is a narrow makeshift, that is an inferior one whether scientific research supplies us with true ideas, with truth in its highest form and last instance, or merely with poor "substitutes" which have above them the Inconceivable - this problem of the Theory of Cognition is eminently a Socialist problem.

All the ruling powers which have exploited the people have to this very day appealed for justification to a higher destiny, to the grace of God, to the holy ointment, to the metaphysical incense. And if they also referred to enlightenment, religious freedom, political progress and critical philosophy, they knew very well that without "something higher," something inconceivable, something metaphysical, be it even a mere " moral world," the reins will break which keep the people straight and the ruling classes in wealth and dignity.

But let there be no misunderstanding. Not that the Social-Democracy are against the moral world. We, too, desire to arrange the world morally; but we desire this arrangement to emanate from the many below, and not from the few above, that is, we desire to arrange it ourselves. We, therefore, need no chimeras, no "limits of cognition" to effect and to keep up such an arrangement. It is, on the contrary, preeminently the business of Social-Democracy to make it clear to the perverted world that the individual intellect is a poor instrument in comparison with the fathomless problem of science, so that the individual must circumscribe his efforts within definite limits; but that, on the other hand, the faculty of cognition of the human race is as full of possibilities, as limitless, as fathomless as the problem which nature sets before it for solution. The doctrine of mental poverty, the doctrine of the limited understanding of man is the last remnant of the religious humbug. Those who, on 
the basis of the Social-Democratic program, strive to emancipate the working class through the workers themselves, must entirely divest themselves of all the foolish expectations and hopes and philosophical hairsplitting and speculation in so far as it all relates to another world.

This other world is now an exploded notion with science and scientific circles; there is only that portion of it left which deals with the "limits of cognition," and as long as these are supposed to exist, there is still a higher limitless cognition standing behind, and there is also the Inconceivable, and nobody who has before his eyes that phantom will ever arrive at a proper appreciation of, and confidence in, human energy and responsibility.

To transform radically the present immoral world, an energetic consciousness of the unlimited faculty of cognition of the human mind is required. This makes it imperative that we should place all talk of the possibility of a "higher cognition" in the same category where the bodies of the Saints stand who, indeed, have stomachs, but need no food, no drink. If another sort of cognition is possible than the one which is commonly called so, then, of course, flesh and blood are possible, too, which look, taste and are constituted like flour and water. In short: we ought, then, to become Catholics, and seek our salvation in prayer and not in active work; we must then give up Social-Democracy.

Our anonymous comrade is of a different opinion. He wants to take up the cudgels in behalf of something inconceivable, in behalf of a limited human cognition, and yet is not willing to stop and keep to those limits. Those who really believe that there is something inconceivable must and will keep away from it with their conception 
and not try to penetrate further and inquire,- else they treat the supernatural as if it were natural, and the inconceivable as if it were merely not yet conceived. An equation like this, our opponent thinks, is merely an " external" one, the contradiction only a superficial one, since it indicates only that the human mind, which involuntarily affects that equation, is reluctant to admit the existence of the Inconceivable and, therefore, pronounces it merely to be not yet conceived. "If it did do that; if, on the contrary, it were to accept that there really is something inconceivable, which to it is like a sealed book, then under such an acquiescence all incentive towards inquiry would be lost and there would no longer be any science."

From this it follows that man has two minds: one which must needs have something inconceivable, and another which must needs inquire into it. As against that I hold that the time has arrived when the human mind must be taught that the inconceivable is not a subject for science and that scientific inquiry has more than enough food in the domain of things yet to be conceived.

" This," says our opponent, " is really nothing but the old controversy over again about the limits of human cognition,- a controversy which your (the Vorzärts) correspondent has presented in a way of his own with which I am not quite in sympathy. "Let us see, then," he continues, "whether our professors of Philosophy have really treated this point so badly as to deserve a curt dismissal."

"The one who first carried out the investigation into the limits of cognition was Kant. However, he did not proceed beyond the ' Categories of Understanding,' and had in his 'Practical Reason' to assume hypotheses 
which gave his system a contradictory character. It was, however, this circumstance in his system which, although the limits of formal cognition had been defined sharply enough, made further progress a necessity. And what else was it than the endeavor to conceive the inconceivable, that is to solve the inner contradiction of thinking?"

"Fichte it was who attempted the solution, etc."

"Then it was Hegel who came nearer to the inconceivable by a far greater step by demonstrating, etc. . . He showed that, in order to understand the World-Reason, it is only necessary to understand our own Reason. This, it is patent, brought the Inconceivable appreciably nearer to us. And when we thus consider to what an extent those three philosophers have advanced our scientific understanding by attempting to conceive the Inconceivable we must take some care not to condemn the "official" Philosophy and to give her notice to quit."

The reply of the Social-Democratic philosophy is as follows: It never thought of refusing the philosophers of the past what is historically due to them. On the contrary, it starts from the premises that Kant, Fichte and Hegel have transformed the Inconceivable (i. e., the faculty of cognition) into the Conceivable to such an extent that the time has at last arrived when we can give all metaphysics with its official philosophers notice to quit,- and also all those thinkers who fail to recognize this important achievement and do not cease making an Inconceivable of everything which is not yet conceived. The ".Critique of Pure Reason," the "History of Science," the "Logic," or the theory of cognition has in its development advanced so far that now SocialDemocracy has a clear knowledge of what is meant by to 
know, and we may well speak with derision of those learned capucines who place above the knowledge of nature something " higher" still.

Kant is said to have "sharply enough defined the limits of formal cognition." This is precisely what we dispute with all our might - the point that separates radically the Social-Democratic philosophy from the official. Kant has not sharply enough defined the limits of formal cognition because, with his famous "thing in itself," he still left the belief in another, a higher cognition, in a superhuman monster-mind. Formal cognition is knowledge of Nature! The philosophers may sigh for another sort of knowledge, but they are, before all, bound to give us some indication where it is to be found and how it is constituted.

Of the real cognition, the one which is in daily use, they speak contemptuously like the ancient Christians spoke of the "weak flesh." The actual world is for them only an "appearance" and its essence a mystery. Long after this rotten phrase has become discredited in other branches of science, the fraud is still being perpetrated in the theory of cognition. Nobody will have any other sort of tin than natural tin, why should it be different with knowledge? If natural science is content everywhere with the phenomenon, why not with the phenomenology of mind? Behind the "Limits of formal cognition" there always hovers the higher, unlimited metaphysical mind; behind the official philosopher, the theologian, and behind both of them, the Inconceivable.

And when Hegel showed that, " in order to understand the mind of the world it is only necessary to understand our own mind," we declare ourselves perfectly in agreement. Only the Social-Democracy would correct 
the mystical expression: we know only one mind, the human mind is the mind of the world.

"But what is this Inconceivable?" asks the author of the letter to the Vorwarts. "When we are forced to acknowledge that every scientific attempt to conceive it brings us appreciably nearer to it, are we not bound at the same time to believe that it will eventually become the Conceived? Then we should have the demand of your correspondent fulfilled,- not, indeed, in his way, but in that of official philosophy. To this, too, the official philosopher has his reply, namely, that "Being," as in a state of absolute rest, can by no means be resolved into the absolute movement of thinking. This dictum, says our opponent, defines at once the limits of knowledge, that is, the Inconceivable. Does it follow, then, that we must deny its existence, and that we must keep away from it? Surely not. Every scientific attempt to approach it, to conceive it, or even to formulate the problem of it, leads us nearer to the obscure point and throws new light on it, though it may never bring us to an absolutely clear vision of it. And the pursuit of this object is the business of philosophy in contradistinction to natural science which only deals with facts and explains phenomena."

\section{Phenomena! Of course!}

Thus the subject of philosophy, the Inconceivable, is a kind of a bird from which we can now and then pluck out a feather or two, but are unable to strip it to the skin, and which must forever remain inconceivable. If we examine closely the feathers which the philosophers of the past have already plucked, we recognize by them the sort of the bird: it is the human mind. And here we are again at the decisive point which separates the dialectic Materialists from the pure Idealists: mind is to us a 
phenomenon of Nature, while Nature is to them a phenomenon of mind. If it only stopped there! But no, there lurks in the background the malicious intention to promote mind to an "entity," a thing of a higher descent and to reduce everything else to a platitude.

We are, therefore, bound to call attention to the fact, well known as it is to the world at large, that not only mind, consciousness or apperception, but all things are "in the last resort" inconceivable.

"We are unable to conceive the atoms, and we cannot explain out of the atoms and their movement the slightest phenomenon of consciousness," says Lange in his "History of Materialism," and another writer also says, "the nature of matter is absolutely inconceivable." And yet we continue to inquire into their nature, because of our need of causation or, as it is also called, "impulse towards research," which, in its irrepressible way, cannot help plucking feathers even from the Inconceivable.

As against this we say: that which allows of being possibly conceived is not inconceivable. Whoever wants to conceive what he considers inconceivable, cannot be taken seriously. Just as with my eye I can only perceive the visible, with my ear hear only the audible, so with my faculty of conception I can only conceive the conceivable. And when the Social-Democratic philosophy teaches that everything which exists can be perfectly conceived, it does not thereby deny the Inconceivable in a natural sense. We admit the same as the naturally invisible for our eyes; we only object to that double-dealing, shuffling "philosophical" sense which makes the Inconceivable again conceivable on a higher plane. We are earnest about this question, we know of no higher and other cognition than the ordinary human one, we know positively that our understanding is truly called under- 
standing, and there can as much or little be any other and essentially different understanding as square circles. We place the intellect among the ordinary things which cannot change their nature without changing their names.

The Social-Democratic philosophy agrees with the official one that "Being can by no means be resolved into thinking "- not even a particle of it. But neither do we regard it as the task of thinking to resolve Being, but merely to arrange, to order it formally in classes, to explain its rules and to find its laws,- in short to arrive at what is called "Knowledge of Nature." Everything is conceivable in so far as it can be classified, everything is inconceivable in so far as it cannot be entirely reduced to thought. This we cannot, must not and have no wish to do, and therefore we keep away from it. But we can very well do the reverse - namely, to reduce thinking to being, i. e., to classify the faculty of thinking as one of the numerous modes of existence.

My opponent appeals to the fact that Kant, Fichte and Hegel have come nearer to the Inconceivable by a few steps. But what those philosophers have grasped was nothing inconceivable, but merely the conceivable portion of the intellect or the "formal cognition." We only go a little step further and conceive the intellect as totally a formal instrument which can only perform in the theory of cognition what it practises in natural science. With us science is a homogeneous species of which philosophy and knowledge of nature are varieties,- - both observe "given facts" or explain "phenomena." We find intellect to be as much empirical as matter. Thinking and being, subject and object exist in the domain of experience. To characterize one of these natural objects as absolute rest and the other as absolute motion is, since 
natural science has reduced everything to motion, no more permissible. What our comrade said of the Inconceivable - namely, that every scientific attempt leads us a step nearer to the obscure point, though we can never gain an absolutely clear vision of it,- is also true, without mystification, of every object of natural science, of the inconceived. Also knowledge of Nature has its unlimited objective; even without mystic limits we approach the obscure point ever nearer and nearer without ever bringing it within full vision. That means simply that science, like nature, has no limits.

Granted, however, that impulse towards enquiry is inherent in man, it cannot be denied that, in order to use this impulse rationally, one must properly understand it. The rational impulse towards enquiry tends to a certain systematic arrangement of existence, i. e., to find out the laws of existence. If it exhibits the tendency to go beyond existence, it must go beyond itself, beyond all nature. With such aspirations Philosophy necessarily overshoots itself and falls into extravagance which it inherited from religion. Philosophy and religion miss the "final causes" of all conceivableness: namely, the empirical, the fact; our thoughts should be based on sense-perceptions, on experiences. Those who, on the contrary, wish to base fact on mind or logic must understand this merely in a formal sense. The last cause why the stone falls or heat expands is the fact, and the law of gravitation and the law of expansion are abstractions or formal reasons. Not only can Being not be resolved into Thinking, but even the philosophic aspiration to do so is a pure-ideological overstraining.

Just as man is possessed by the impulse to know everything, so he possesses also the impulse to see everything. Well, here is a pane of glass which is quite 
transparent. Yet it is not all transparent. Its specific gravity or degree of solidity cannot be seen; its quality to emit a sound can only be heard, etc. Precisely the same with the organ of knowledge: we are able to know everything completely, yet along with this everything is something more than knowable, and this fact that Being cannot be resolved into thinking can be a matter of lamentation only to the fantastic dreamer. If we could know of any one thing absolutely everything, then knowledge would be all and the object nothing. Knowledge and nothing left to know! Light and nothing left to see! Then it would be like of yore when nothing was - " and the earth was without form, and void." 


\section{OUR PROFESSORS ON THE LIMITS OF COG- NITION.}

(VORWÄrTS, I878.)

I

At the "Fiftieth Meeting of German Naturalists and Physicians," held at Munich, September, 1877, Professor C. V. Nägeli, of Munich, took up a well known lecture of his Berlin colleague, Du Bois-Reymond, and delivered a remarkable address on the "Limits of Scientific Knowledge." One is bound to admit that the Munich professor has, in point of truth and clearness, far surpassed his Berlin colleague; still he, too, was unable to rise to the level of his time.

He nearly explained the whole thing; but the small point which he missed at the conclusion is just the vital point, - the one which marks the wide gulf that divides physics from metaphysics, sober science from romantic belief. Such a lecture, proceeding as it does sharply up to that point, offers a welcome opportunity to show once more the superiority of the Social-Democratic conception of the world.

Prof. Nägeli treats his subject in the following manner: "Many methodical scientists who, by their exact mode of research, augment the stock of well based facts, while holding a fundamental solution inadmissible, answer the question as to the Limits of Knowledge of Nature by a simple statement of fact: 'Belief invariably begins where knowledge ends.' The statement that our 236 
belief begins where knowledge ends - the lecturer continues - is a practical solution for certain definite purposes. Our interest is not satisfied thereby. We turn our special attention to the theoretical side of the problem. We want to know whether the limits where human knowledge must stop are at all definable, and if so, how far can knowledge penetrate into the domain of Nature; how much of Nature could the human mind conceive, if it were to occupy itself during an unlimited time - say, an eternity - with natural sciences and have at its command all imaginable means of research,- in a word, what is the fundamental line of demarkation between the domain of knowledge and that of belief?"

As is well known, his predecessor, Du Bois-Reymond, tried to prove that there really is such an impassable line of demarkation, that consequently belief will, under all circumstances, have a domain of its own left to it. It is only owing to the reservation of this little refuge for religious romanticism that his lecture has gained its seeming importance and popularity. Since that time the champions of the Inconceivable have not ceased singing Hosanna. True enough, Prof. Nägeli is little edified by this song, but his official privileged position as a professor does not allow him to enter the fight in a wholehearted manner. After showing his predecessor clearly and by all manner of means that he has misunderstood the nature of scientific knowledge, he concludes as follows: "Du Bois-Reymond winds up his lecture with the crushing words, Ignoramus and Ignorabimus. I should like to conclude mine with the qualified, but withal, consoling expression of opinion that the fruit of our researches is not merely knowledge, but actual truth which contains within itself the germ of an almost (!) infinite growth, without thereby coming nearer by the 
smallest step to omniscience. If we adopt an attitude of a reasonable resignation, if we, as finite and transient beings that we are, content ourselves with human knowledge instead of claiming divine cognition, then we may say with full confidence in ourselves and in the future: 'We know and we shall know.'"

These concluding remarks contain the essence of the question. They also unmistakably express both the religious and subservient consciousness of the Berlin professor and the tame and timid inconsistency of the Munich one. The religious romanticism of Du BoisReymond calls all results of scientific research " merely knowledge," and not " real truth." Such true cognition is not attainable by the poor human understanding. The professor literally says that " the whole of our knowledge of Nature is in reality not cognition, but a substitute of an interpretation."

Our science, then, can only yield chicory instead of coffee. Our scientific interpretation may very well allow itself to be buried, perhaps it may rise transfigured on the day of judgment. And such reactionary wordsplitting wants to dominate our universities!

Then comes the other one, Nägeli, to whom that pious resignation seems rather too strong. The nice distinction between knowledge and cognition does not recommend itself to him. He is convinced that "we know and shall know." But observe how gently he breaks this news to us: "without thereby coming nearer to omniscience by the smallest step." $\mathrm{He}$, too speaks humbly of "human" cognition as against that of the higher NonHumanity. We must submit to a "rational" resignation and lay no claim to "divine knowledge." Is it possible that so learned a professor should " resign" himself monklike to divine cognition and even call such resig- 
nation rational? All natural cognition is divine, that is, glorious and wonderful. When, however, our professor opposes to human cognition a divine one, then he proceeds beyond the limits of Nature and lands in the same romanticism in which his predecessor has landed before him.

The Munich professor has clearly shown to his Berlin colleague that by not recognizing our knowledge of Nature as a real, true cognition, he demonstrated not the limits, but the inanity or absolute impossibility of scientific cognition. And, consequently, he stands at a purely negative point of view. According to Nägeli, Du BoisReymond teaches as follows:

I. Cognition of Nature is the reduction of a natural phenomenon to the mechanics of simple, indivisible atoms.

2. Atoms in this sense do not exist and, consequently. no real cognition exists.

3. Even if the world could be understood out of the mechanics of the atoms we would still be unable to understand out of these atoms apperception and consciousness.

On this Nägeli justly remarks: "Since the speaker does not proceed beyond mere negation, natural science cannot, in its lack of a proper domain, draw its limits either,-and if it is for ever unable to gain an insight even in the material phenomena, it matters little whether it may possibly lay claim to the spiritual domain." In other words, if our knowledge yields instead of coffee only chicory, then we only have one bad brew and nothing else. There is nothing good left which it would be worth while to investigate, to understand or to place within its proper limits. 
After one professor has thus settled the other, the pleasant duty remains for us to show, what, however, must be clear already, that the Munich professor, too, has landed where the other one was caught. Herr Nägeli differs from $\mathrm{Du}$ Bois-Reymond in that he has so far broken loose that it is difficult to judge whether it was because his strength has failed him or on account of decorum, that he felt himself obliged to keep to the " mysterious land of presentiment," to the "divine cognition and omniscience" and such like things which "surpass our human faculties."

"As regards the faculty of the Ego to know of natural things, the decisive and undoubted fact is that, however our faculty of thinking is constituted, only the sensory perception offers us any knowledge of Nature. If we did not see and hear, did not taste, smell or touch anything we could not altogether know that something exists outside us,- nay, that we ourselves are corporeal."

These are brave words. Let us adhere to them and see whether our professor sticks to them also.

Our sensory perception, says our lecturer, is limited to the present. "We cannot in a direct way perceive what was in the past and what will be in the future, nor what is too distant in space nor what is too small or too large in dimension."

Quite so. But what one man did not see yesterday another one will see to-morrow. Where the distances are too great and the dimensions too small, there we call to our assistance the telescope and the miscroscope. "Thus it is possible, theoretically speaking, for the human organism to get bodily impressions of all phenomena in Nature. But how does it stand in reality? What impressions are powerful enough to be noticeable 
to us and what are insignificant enough to pass by unnoticed?"

We are not going to follow the lecturer in all his details, but will readily acknowledge what always has to be acknowledged, "Our faculty to get direct perception of Nature through the senses is limited in two respects. We probably (!) lack the perception for whole domains of Nature (is it for that of goblins, ghosts and the like? J. D.) and so far as we possess it, it merely embraces in time and space an insignificant portion of the whole." (Yes, Nature surpasses the human mind, it is an inexhaustible object, J. D.) "Of the constitution, properties, history of a fixed star of the last magnitude, of the organic life on its obscure satellites, of the material and spiritual movements in those organisms - of all that we shall never know anything."

Here, again, our professor goes too far. Our faculty of research is only limited in so far as its object, Nature, is unlimited. We cannot arrive at any end, simply because there is no end. But where there is an end, there we may possibly arrive. No professor can tell how much of the fixed stars and their satellites we and our successors may yet find out, how infinitely deep we may yet penetrate into the past, into the future and into the smallest particles, since, as Nägeli himself says, we have "theoretically" speaking, every possibility for that. We know that no explorer will ever find two mountains without a valley, no cutter will ever make a knife without a blade and handle, for these are all theoretical impossibilities. But what results practice will still achieve - to determine that in advance, after the spectral analysis and the invention of the telephone, is surely a piece of impertinence. 


\section{III}

Inquiry never arrives at an end - neither objectively nor subjectively; neither the infinity of the world, nor the infinity of the intellect admit of an end; that, however, the intellect is but a limited portion of the world, no Social-Democratic materialist will ever deny. On the contrary, it is precisely he who scientifically conceived the thinking faculty as an instrument, quality, product or part of Nature. We are not animated to such a presumptuous extent by mind as to ascribe to it every capacity and every faculty. We only wish - what our professor wished, but could not achieve - we only wish to escape from dualism. We can only acknowledge one solitary world - the one "of which we obtain knowledge through the sensory perception." We keep Nägeli to his word, namely, where we do not see or hear or feel or taste or smell anything, there we can not know anything either.

I wish to return once more in a positive manner to the perceptibly limited nature of human cognition. With this faculty we can only know; to sing, to jump and to do a hundred other things with it we cannot; in so far reason is limited. But in its own element, in cognition, it is unlimited, and so unlimited that it never comes to an end with its work.

To go on. Everything knowable is open to it. The unknowable, that which is absolutely inaccessible to the senses, is for us non-existent ; it is also "in itself " nonexistent insofar as we cannot even speak of it without drawing upon the fanciful.

"Our senses are just organized for the needs of common life, but not in order to satisfy our mental need, and to give us knowledge of all phenomena of Nature. 
. . Just as we came to know something about the clear ical phenomena which have their seat in every particle of matter, so there may be yet other natural forces, oher moleculer forces of motion of which we do not get any sensory impression, because they never unite into an observable sum, and therefore remain hidden from us."

We reply: Those who have the 'mental need' to know something of phenomena ' which remain hidden from us,' and must remain hidden according to our Nature, have not a mental need, but a mystical need. The electrical phenomena have no more been discovered by accident than America was. And what a strange Columbus a scientist must be to speak of phenomena which nobody ever perceived or will perceive. It is possible that Mephistopheles should hover about me in the form of an invisible rearmouse; but what I don't know leaves me cool and ought also to leave cool every natural philosopher.

Nägeli says: "The natural philosopher must well be aware that his inquiry is confined in all respects by finite limits, that on all sides he is categorically bidden to halt by the unknowable eternity. That this has not always been understood, that the infinitely great and the infinitely small have been mistaken for the endless and nothing, has often led to erroneous ideas. Such are the erroneous theories of the physical atoms as the infinitely small, and of the beginning and end of the world as the infinitely great."

The consciousness of the limits of research may, eventually, be useful to the scientific inquirer. Still our professor ought not to have forgotten that rational doctrine in the very same breath in which he propounded it. This he does when saying that " on all sides we are categorically ordered to halt by the unknowable eternity." 
How can one know anything about this 'halt' when it is unknowable? Or is Nägeli, like Du Bois, perhaps, unable to escape from the mere negation? Can he, too, only tell of the great halting-point of the 'eternal,' that nothing can be known about it?

Nägeli continues. "This is not to say that the scientist must not philosophise, that he must not enter the domain of the ideal and transcendental. But he ceases to be a scientist, and the use he can make of his own profession is to keep the two domains strictly apart, that he treats the one as the real domain of research and knowledge, and the other, freed as it is of all finite, as the occult domain of presentiment."

Our good professor knows the philosophers badly if he thinks that they will content themselves with the 'occult domain of presentiment.' Not only the Social-Democrat. but also many ' official' philosophers, claim that although their domain be hidden from the Munich professor, it is still open to 'human understanding,' and that all ' divine cognition' must be rigorously excluded from it. The occult domain or the metaphysical world beyond is not nearer Philosophy than to the other pure ideologists who seek each and every one to find some snug corner for their shrines. With science these conservative endeavors have nothing to do; they belong to the domain of practice. On the other hand, there is much more that belongs to the domain of exact science than those gentlemen are at all inclined to admit. They consider the conception of Nature in too vague a fashion. If it cannot be disputed that History, Economics, Politics, etc., ought to develop into exact sciences, nay, are already in a fair way to do so and have already partially done so, then SocialDemocracy can also prove that the gulf between Philosophy and Science has already been bridged over with- 
out the bourgeois geniuses getting the slightest wind of it.

Professor Steinthal has gone in this respect further than his scientific colleagues. In the third edition of his book, "The Origin of Speech," he says: "Speaking is not thinking, but the means, the organ of thinking," and " no mind is without speech (designation); speech itself already belongs to the domain of mind." Continuing this train of thought we argue: Speech lends our ideas their true designation. What speech designates as Nature, truth, knowledge and tin is really and truly tin, knowledge, truth and Nature. Steinthal teaches us on this point as follows: A only equals $A$ and never B, if ' equal' is not taken in the mathematical sense of being equal in magnitude. But if 'equal' means equality in essence, then $A$ equalling $B, B$ must be $A$, and we have no right to call it otherwise than A. Steinthal calls this "the principle of research and knowledge." In other words unity, unity in conception and name is the first condition of science. All dualism is untenable. If divine knowledge $=\mathrm{A}$, and human knowledge $=\mathrm{B}$, that is, if both are essentially different, then we simply juggle with the word knowledge in a dualistic manner. Just as all mankind, in spite of the different races, make but one species, so necessarily is there in spite of the diverse kinds but one knowledge, one truth, one Nature,- the true Nature, the natural truth. And everything we get to know in heavens, on earth and in other places belongs to the same category. And what we do not get to know and of which only the parson and the professor tell us,is mere jugglery, which, however, belongs to the natural truth, that is, true jugglery. 
IV.

Nothing more is meant by these deductions than this: the world is a unity, that is, there is only one world. And whoever wants to pass over to another world - from that of experience to that of presentiment or divinity,nay, whoever merely speaks of it, is either a 'crank' or a scamp or a deceiver of the people. To have the right to stigmatise an opponent with one of these bad names no further proof is required than that he contradicts the "wants of Reason for unity."

When Nägeli tries to impose upon his colleagues at the meeting of scientists the belief that our intellect has, or, perhaps, has outside of the bounds of its own nature yet other, supernatural or unnatural limits, he performs thereby a scandalous trick, the more scandalous, in fact, the further he has progressed in the conception that Nature represents an organic whole where no gulf could be found.

"Our knowledge of Nature is thus always a mathematical one and is based either on simple measurement, such as in morphological and descriptive sciences, or on a measurement of causation as in physical and physiological sciences. But with the assistance of mathematics, of measure, weight and number only relative or quantitative differences can be understood . . . Real qualitative differences we cannot determine since qualities cannot be compared. This is an important fact for the knowledge of Nature. It follows from this fact that if there are in Nature qualitatively or absolutely different domains, scientific knowledge is only possible in an isolated way within the bounds of each of them, and no connecting bridge leads from one domain into another. But from the same fact also follows that in so far as we car 
investigate Nature connectedly, in so far as our measuring knowledge proceeds in a consistent, uninterrupted way, and as we come to an understanding of one phenomenon by means of another . . absolute differences, impassable gulfs do not exist in Nature at all."

This passage shows how very near our Munich professor came to a right and complete conception of the nature of knowledge. It is only wanted to dot the i's and to cross the t's. This little thing however, is of infinite importance, since without it one always slides back into the intolerable error of wishing to formulate absolute or qualitative differences, to separate by an impassible gulf the finite and infinite or the human and divine knowledge, and to describe two domains without a connecting bridge.

This dualistic scandal must once for all be put an end to by going one little step further than Nägeli. The faculty of cognition must be recognised as the faculty which embraces all differences, all qualities as a unity, as one solitary quantity. It is rational means: reason makes of all existence one order. To enroll under this order all the phenomena of the world as different species, is to know Nature. Because the intellect can do this, because it divides everything into orders and species, into subjects and predicates so that finally only one order remains, only one subject, Being or the Given Premises of which mind and body, reason, fancy, matter, force, etc., are predicates or species, - because of that there cannot possibly remain in the world any impassable gulf. Everything must reduce itself to a theoretical harmony, to one system.

As soon as this $i$ is dotted, it becomes no longer possible to talk grandiloquently that there can be an absolute 
difference or impassable gulf between the inorganic and organic, between plant, animal, ape, man, mental and manual work, etc. One must know that two drops of water are just as infinitely different as animal and man, as body and soul, and that separation and differentiation are just as little limited as "striving after unity."

I should like to make the reader understand what the professors, so far as I know them, have not yet understood, viz., that our intellect is a dialectical instrument, an instrument which reconciles all opposites. The intellect creates unity by means of the variety and comprehends the difference in the equality. Hegel has made it clear long ago that in science there is no either - or, but as well as. The faculty of knowledge in the ape, the rustic and the scientist is just of the same category as that in the philosopher, and also the most divine knowledge belongs to the same category, and are all forms of one variety, varieties of one order, predicates of one subject. It is certainly admissible to distinguish between the human and the animal intellect, to raise the former to the skies and give it a different name. But it is just as inadmissible to create an impassable gulf between reason and instinct. If we reason soberly and do not indulge in extravagant exclamations we are bound to recognise that the faculty of discrimination separates infinitely but also connects endlessly.

Nägeli says: "It is a logical necessity for the scientist to allow in the finite Nature only gradual distinctions." Our reply to this is : it is a logical necessity to throw the infinite and the finite into the same heap, that is to conceive of Nature as a unity which is both finite and infinite.

"But what is the world which is dominated by the human mind? Not even a grain of sand in the eternity of 
space, not even a second in the eternity of time, but is an outwork of the true essence of the All." That's exactly the language of the parson. And it is quite true, if it is only meant as an emphatic expression of sentiment in view of the greatness of existence; but is also very insipid, if the professor takes it to mean that our space and our time were not part and parcel of the infinite and eternal,- very insipid, if it is meant to express that the ' true essence of the All' is hidden beyond the phenomena in the infathomable region of metaphysics or religion. The All is to be found in its moments, and to seek it elsewhere is a task which Social-Democrats willingly leave to the ruling classes.

\section{V.}

After Prof. Nägeli had thus tried to curb our scientific knowledge of Nature his example was followed at the same meeting by Prof. Virchow in order to restrict still further the "freedom of science in the modern State." His eyes are so sensitive that they cannot stand even the feeble light which Nägeli had put up.

"I should like to prove to you that we have arrived at a point where we must make it our special business to modcrate ourselves and to renounce to a certain extent our predilections and personal views so as to keep up the good temper which the nation still exhibits towards us."

What a miserable " nation" this is, whose good temper the professor desires to preserve, will prove no puzzle to our comrades. We recognise the well-to-do by this mere predilection for the moderation of others, by their sensitiveness to everything which may interfere with their digestion.

"It goes without saying that we must demand for everything which we consider to be well established scien- 
tific truth complete adoption in the national store of knowledge; this the nation must absorb, - this it mus? consume and digest."

Our professor is right; there are some truths which are too patent to allow of being hushed up, and there are others which can serve the revolutionary tendencies and must, therefore be "moderated," though science un" mistakably gravitates to them.

"We cannot proceed to explain to every yokel: this is true, established by fact, this is fairly known and tha" is only a conjecture. . . . We must abstain from putting into the heads of our schoolmasters what we merely conjecture. . . . After all, this theory of evolution, too, when consistently carried to its logical conclusion, has some very dangerous aspects, and it will not have escaped your attention, I hope, that SocialDemocracy has taken cognizance of it."

This hardly requires any comment. One needs only listen to the man to perceive at once how it stands with the "Freedom of science in the modern State." Knowledge must naturally be still more restricted by Virchow than it was by his colleague, Nägeli.

"In thus narrowing the limits of our knowledge we must remember above all that what is commonly called natural science is like all other knowledge in the world made up of three heterogeneous elements. Usually we merely distinguish between objective and subjective knowledge. Yet we have still a third, a sort of medium element, namely, that of belief, which, as you know, also exists in science."

This subtle distinction which the artful dodger, for the sake of his reputation, thereupon draws between scientific and religious belief, need not be taken seriously, but the ingenious way in which he scents the weak points of 
his predecessor deserves some acknowledgement. Nägeli had said:

" Reflex action is clearly bound up in higher animals with sensitiveness. We must also grant it in the case of lower animals, and we have no reason to deny it in case of plants and inorganic bodies. . . . In virtue of its structure out of different parts the atom possesses various properties and powers, accordingly it also exercises various influences (attraction and repulsion) upon other atoms. . . . If, therefore, the molecules experience something akin to sensitiveness it must also be a pleasure to them if they can follow their sympathies and antipathies, etc. . . . The molecules of chemical elements are, therefore, swayed by a number of qualitatively and quantitatively different sensations.

We accordingly find in the lowest and simplest organizations of matter of which we know, essentially the same phenomena as in the highest. . . . The difference is merely that of degree."

To that Virchow replied: "This is the objection which I make to the statements of Herr Nägeli.

He not only wants us to extend the domain of mind to animals and plants, but also that we finally pass with our views of the nature of mental phenomena from the organic to the inorganic world. . . . If mental phenomena are at all costs to be brought in connection with those of the rest of the world, then one necessarily arrives at transferring first the psychical phenomena as they are found in man and the highest organized vertebra to the lower and ever lower animals, and then to endow even plants with a soul; then it is the cell which feels and thinks, and finally there is a gradual transition even to the chemical atoms which hate and love each other. seek or avoid each other. . . . I do not object to 
atoms of carbon also having a mind, . . . but I do not see anything by which it could be known. It is a mere play upon words. By declaring attraction and repulsion to be mental, psychical phenomena we simply throw the psychical overboard. . . . To us the sum total of psychical phenomena is undoubtedly only associated with certain animals and not with the whole of organic life, not even with all animals. This I declare without hesitation."

We must acknowledge that Virchow is in one respect perfectly right: ideas with a distinct meaning in language should remain distinct. One must not play with words; but neither must one shut his eyes to the fact that the psychical sensation of pleasure and pain presents a certain analogy to the chemical attraction and repulsion. Let us only dot the $i$, and then the two will appear as equally legitimate forms of the same Nature, as the equally intelligible predicate of the same subject. Only those who utterly refuse to connect the mental phenomena with those of the rest of the world, will fail to perceive that the animal and chemical, the physical and psychical phenomena are common varieties of the great world process. And once more, gentlemen: The world is dialectical, as much one or homogeneous in essence as varied in the manner it appears; all distinction is only that of degree. The unity which Nägeli defends is lost to him as soon as he lands in "the world of presentiment" and at "divine omniscience;" but that unity is already lost to Virchow when he merely arrives at the distinction between organic and inorganic; still more intolerable is to him the link between animal and man; and as for the opposition between body and soul,- this he wants to keep outside the province of debate altogether, as the bridging over of this opposition " in the 
head of the Socialist" was bound to cause an awful confusion and lead to the overthrow of all professorial wisdom. 


\section{THE INCONCEIVABLE}

A SPECIAL CHAPTER IN SOCIAL-DEMOCRATIC PHILOSOPHY

(VORWÄRTS, I877)

Both the clergy and the professors are of the opinion that the human intellect is debarred from the greatest possible knowledge and from the clearest possible understanding. They agree in their endeavor to preserve to the human intellect the character of the limited understanding of the poor commoner. Yet there is a difference between the two camps. The clergy keep account of the human desire of a perfect light, in so far as they refer the poor commoner's intellect for support to the great spirit above who, through his revelations, enlightens and makes known to man what is good for him to know. The Philosophers of our Universities, on the other hand, have their doubts about the great spirit above; they are progressive and they substitute the earthly knowledge for the divine one, but for all that they show the same dualistic, half-hearted character in abstract thought as their colleagues, the "Progressists," in politics. They exhibit the same mixture of mala fides and incapacity in wisdom as these colleagues in matters of liberty. They cannot make an end to all secret-mongering; and if they find no mystery in heaven and the sacraments, then there must be something mystical in "the essence of things" and in "the ultimate reasons" of Nature, some insurpassable barriers or " limits of our cognition of Nature." Against such inveterate mystics it is as Social- 
Demorrats our bounden duty to proclaim the limitless passibilities of the human intellect.

No doubt there is much in Nature which is not yet known,- who would deny that? Where is the man who never mot with phenomena which he called wonderful, inexplicable, incomprehensible! Who would find that unnatural? But what is really wonderful, incomprehensible and inexplicable is that there are still in the second half of the nineteenth century certain scholars who seriously speak of the limits of human understanding and believe in the real existence of wonderful things, of miracles which are beyond the understanding not of Peter or Paul, but beyond the horizon of mankind.

We must, however, soon recover from our astonishment and try to comprehend the incomprehensible. And to do this, it is necessary to find the category to which it belongs. The incomprehensible is explained as soon as we recognise that it belongs to the category of thoughtlessness. It may appear presumptuous on my part to speak so disrespectfully of a thing which is treated by high authorities with such a solemn seriousness. In science, however, all belief in authorities must cease. The capacities of the human intellect are so unlimited that they, in the course of time, make new discoveries, open new vistas which regularly make the old authorities appear as mere duffers. Though I am defending the view of the unlimited capacities of the human intellect, I am none the less thoroughly conscious of the limitation of all men and all times, and so I am, despite my exuberant spirits, a modest fellow.

The intellect is, as is well known an organ with which we perceive. From the other organs of perception it is differentiated by its being the most essential factor. Without eyes we may still hear, taste and smell but with- 
out consciousness, without the spirit in our head the whole world is at an end. On the other hand a consciousness without the aid of the senses would know nothing. Thus it may be seen that they all belong together. The intellect may be a captain but only so in connection with the private soldiers, our five senses and the things of the world.

We may even regard the senses of man deficient, because there are animals whose senses are more developed than his, but with regard to intellect man is no doubt superior to all other "creatures." "In this world" nobody has ever met with a superior mind to that of man. How it stands "in the other world" with angels, goblins and nymphs, history can tell us nothing about that. And even if we admit for a moment that supernatural spirits crowd the stars and moons, they must, insofar as they bake bread, use flour, and not metal or wood for this purpose. If the supernatural spirits are endowed with reason, then that reason cannot be of any other general nature than ours. If the metaphysical intellect is different, and perhaps of the nature of wood or tallow, then we must be permitted to deny it the name of intellect. We may only use the language as it is customary. It has divided things into classes and varieties and we must accept them as such if we want to be comprehensible and reasonable. If there are things in heaven or in some transcendental region, which are of a nature totally different from the things on earth, then they must be given other names; and not being adepts of the angel-language we cannot reasonably say anything with regard to "something higher," the metaphysical or ghostly.

Strange and yet true! Such reasoning is exasperating to our philosophers. Kant has told them something and they are going on rehearsing it: only the natural phe- 
nomena can be conceived; but what is behind them, the "thing in itself" or the mystery - that, thou poor human intellect, is inconceivable by thee. And yet that whole mystery, the whole secret, is nothing but an exaggerated idea which they got about the intellect. Although they pretend limitation and continually speak of the incapacity to go beyond the limits of cognition, they cannot get rid of the exaggerated notion of an inconceivable conceivability, or of the idea of a monster-mind who could understand where there is nothing to be understood.

Aha! - my keen opponent will retort - you see! you speak somehow of things which no man can understand. Then there are inconceivable things. Well, well!

Yes, my dear mystic! I should like to see the wonderful things discussed, provided that they are stripped of their wonderful metaphysical character. There is much that is incomprehensible, there are limits to our understanding, but only in the sober sense of the word, just as there are things invisible and inaudible, just as there are limits to the capacity of our senses of seeing and hearing. Everything has its natural limit, and so has also the intellect. If musical tunes, sweet scents, the gravity of bodies are not visible to the eye, it is because the eye has reasonable limits, and not because the eye has unnatural limits in a metaphysical sense, which denotes human inferiority in comparison with some over-human superiority. Inferior a thing may be in comparison with another of the same class, but in general all things are perfect - they can't be otherwise. A more perfect wood than that which is generally growing on earth could not be grown in metaphysics. When the wood changes completely the character of its kind then we can't call it wood any more. Or should we deal with iron woods? 
Just as wood is limited by its wooden nature, so is the eye limited to visible things. And just as the eye, the general eye, sees all that is visible, so does the intellect, especially the human intellect, perceive everything which is reasonable. Unreasonable things, which can't be reasoned out and understood, do not belong to its domain, and that is no more a defect, a barrier of the intellect, than the incapacity of the eye to see without light, or to feel a toothache. Monster-eyes may possess such an unnatural capacity of seeing.

In order to make an end to the gruesome talk of the Inconceivable and of the "limits of knowledge of $\mathrm{Na}$ ture" in the metaphysical sense it is necessary to be clear about this question: What does it mean to know, to explain, to perceive? I repeat the cause of all superstition, of all religious and philosophic metaphysics, is to be found in the exaggerated idea of the function of the intellect, in the unreasonable demands made upon the faculty of cognition - that is, in epistemological ignorance. Our contemporaries have an inkling of this fact. The learned magazines teem with discussions on that subject-matter, and nearly approach the truth, but the full light is still missing, and can only be given by Social-Democrats. It is the possession of that light which enables our party to handle the intellect with systematic precision and to clear away the philosophic and theological mysteries guarded until now by the privileged classes.

Just as the peasant misunderstands the principle of mechanics, so does the professor of Philosophy misunderstand the principle of the intellectual function. It is difficult to make untrained brains understand that all levers and wheels do not increase the volume of a power. but merely distribute the pressure and thus enable us to 
handle it in an easier manner. But still more difficult is it to convince the professors of Philosophy that all cognition, comprehension and explanation is simply a formal act. The phenomena of the world and of life must be regarded as comprehended and explained when they are divided into classes, families, varieties, species, etc., and brought into a formal scientific schedule showing how they belong to one another and how they follow each other.

When a monster meets me in the forest, which, on account of my defective knowledge of natural history, makes me wonder as to what it is, and when at the same time a naturalist comes along and informs me that it is not a cannibal, but a rhinoceros which belongs to the family of pachyderms whose home is in Africa, Asia, etc., then under such a systematic registration my astonished ignorance turns into clear knowledge. And when I ask the physicist why the falling body increases in velocity from second to second, he will explain it to me by the law of gravitation, that is, he brings the different phenomena into one class and subordinates them under one scientific formula. All our reasoning, explaining and knowing cannot ask for more and ought not ask for more of our intellectual force. Those who demand more of the intellect are like the ignorant mechanic who seeks to invent the Perpetuum Mobile.

"Physics," says Schopenhauer, "explains the phenomena by something still more unknown, by natural laws, natural forces, etc. Such explanations are, like the devil with the cloven foot, afflicted with the defect that they themselves need to be explained." The same philosopher says in another place: "However great the progress may be which physics makes, it does not bring us a single step nearer to metaphysics. . . . Under 
metaphysics I (Schopenhauer) understand any alleged knowledge which goes beyond the possibility of experience, in order to furnish us with information as to what is behind Nature. . . . Even if one has traversed all stars and planets, no step was made into the region of metaphysics." With those words the famous man has stated two things: First, that metaphysics lies in Cloudlands; secondly, that he, with his inordinate desire for crazy explanations, still sticks to the metaphysical craving. He calls man " animal metaphysicum," whereby he wants to say that it is metaphysics which distinguishes man from the animal. As against that I am of deliberate opinion that the descent of man begins just where the metaphysical or philosophical animal disappears.

No doubt, the thing has, as everything else, different sides. Metaphysics or the exaggerated ideas had to proceed in order to lead to the sober view that our intellect is an ordinary, formal and mechanical force. The light of that conviction is even dawning everywhere, but still only dawning. How its ascent is hampered by the old exaggerated ideas may be seen daily in dozens of the learned reviews. For instance, in No. 34 of the Wage, I876, Dr. Kalischer remarks : "Newton as well as Darwin starts from given material, to which the first applies his Law as a measure. But what he shows by such an application is the mathematical, the formal, while the essential of the physical process remains completely unexplained. - . According to that we reach the highest summit of knowledge when we get the mathematical formula; for the so-called 'explanation' goes always so far as we can subordinate the natural phenomena under the principle of mechanism."

Thus Dr. Kalischer knows the highest summit of knowledge, he is, so to speak, in agreement with Hobbes: 
"Where there is nothing to add and nothing to subtract all thinking is at an end," yet he desires to climb to the highest-highest top in order to reach an explanation which overtops the "so-called explanation." Or in other words: Though our thinking force is in the last instance explained when we recognize it as a formal in. strument, yet there are people who speculate upon a monster-reason which should explain the world metaphysically.

I can well imagine how the professors of Philosophy dislike our conception, but I should like to ask them mo3t earnestly to kindly tell us what gives them the right to conclude from the natural limits of reason that there is an unnatural unlimited reason; further to tell us why they don't conclude from the limited nature of a piece of tin-plate that there is a limitless, heavenly, metaphysicid tin-plate. Such a conclusion can only be drawn by ore who does not consider reason or tin-plate to be a natural thing which, like all other natural things, have their fixed limits defined by linguistic usage; only professors and scholars who carry in their bosom the last Mohican of a "higher" transcendental world, an exaggerated idea of a superhuman intellect, can draw such conclusions.

After the clear statements of the philologists Max Müller, of Oxford, or of William Dwight Whitney, that where the limit of things begins their names cease, all limitless fancyful speculations must cease. When our intellect reaches the point where there is ncthing to be perceived, or where the Inconceivable begins, even then we have as little right to speak of a totally different world as when we reach the point with our voice where there is nothing more to sing. Where the singing ceases, howling may commence, and where theory is at an end, practice should begin. 


\title{
EXCURSIONS OF A SOCIALIST INTO THE IX. MAIN OF EPISTEMOLOGY.
}

\author{
(SOCial-Democratic Library, HotTingen-Zürich \\ I887.)
}

PREFACE

The subject of the following articles seems to have so little in common with Social-Democracy that their publication as part of the Social-Democratic Library necessitates a few words of explanation.

The theory of cognition with which these Excursions deal has for its subject-matter the question, how is the instrument in our head constituted which everybody has to use in order to gain knowledge of the natural and human conditions which surround him, to distinguish, judge and understand them.

An instrument which everybody possesses and uses may be called a democratic instrument. The intellect is common to all men and, therefore, is a concern of the community or society, a Social-Democratic instrument, a Social-Democratic concern. If Bismarck uses his instrument differently from Social-Democrats we are convinced that he makes a wrong use of his intellect.

Absolute unanimity we can never attain, yet progress in this direction is unmistakable. So also will the theory of cognition never exhaust its subject and render us infallible in the use of our mental powers; still we must not on that account renounce improvement. Social-Democracy, too, is strenuously working with the view of 263 
making the minds more unanimous; consequently a wellfounded theory of cognition can only be of value to it.

As I say, the theory of cognition deals with the question of how our instrument of thinking is constituted. By learning the nature of it we learn at the same time the use of it. Although the nature and the use of a thing may be regarded as two separate things, it is none the less permissible to coalesce them into one. In my opinion only that person is able to understand the nature of a violin who knows thoroughly how to play it - who knows what there is in it and what is to be done to bring it out of it.

That men, with their instrument of thinking, have judged correctly, thought correctly and discriminated exactly without knowing anything of epistemology is, of course, unquestionable. The farmer knows how to grow potatoes without having attended an agricultural college. Yet one cannot but admit that science makes even the farmer more intelligent in his work. It teaches him how to predetermine the results of his work. If he still remains, in spite of his predetermination, at the mercy of wind and weather, yet it cannot be denied that science gives him the means to control Nature to a certain extent. Absolutely free he will never be; science and reflection cannot help him to sovereign power, still they help him. If we cease to be slaves of Nature we shall nevertheless ever remain her servants. Knowledge can only give the possible freedom which is at the same time the only rational one.

And so the instrument which is analysed in the following pages is used by everyone at every opportunity. Nothing is so general and universal in the world of man as perception, discrimination, judgment, knowledge, etc. The theory of cognition must, therefore, be regarded as 
an elementary study, as the Alphabet, but in a higher sense. A trained intellect goes farther than the art of reading and writing. The celebrated Spinoza already left us an opuscule on the "Improvement of Understanding," and it is to be regretted that his work has been left incomplete. And it is nothing less than the improvement of this instrument that we aim at in the present "Excursions into the domain of the theory of cognition."

Whoever desires to be an intelligent Social-Democrat must improve his method of thinking. It was mainly the study of the improved method of thinking which helped the well-known founders of Social-Democracy, Marx and Engels, in raising Social-Democracy to a scientific standpoint on which it finds itself now. The improvement of the method of thinking is like every other improvement, a limitless problem, the solution of which must always remain unachieved. This, however, must in no wise keep us from striving after it. The only and natural way consists in increasing our general knowledge by mastering the special branches of science. Although the theory of cognition, by setting out to illuminate the lamp from which all light emanates, touches the desired enlightment of the human mind at its very source, we are nevertheless modest enough to acknowledge that such a theory, be it ever so perfect, is not sufficient. Though all special branches of science are conducive to that end, yet none of them is able to form the generalisation which could entirely illuminate the mind. This can only be achieved gradually, wherefore we shall be content if these "Excursions" will have contributed something to the general aim of science.

Chicago, December I5, 1886.

J. Dietzgen. 
" THE inNERMOSt OF NATURE No CREATEd MiNd CAN ENTER."

These words of von Haller are singularly apt to demonstrate on them, how even the "eternal truths" have succumbed to the corroding influence of time. This so often quoted line of the poet has even now numerous admirers who repeat it. The more reason have we to show those who believe in the old wisdom, what progress is being made by the ever-revolutionary criticism.

The "created mind" is the special subject-matter of a special science calling itself "Philosophy." The meaning of this term has undergone many changes. In the times of the ancient Greeks a philosopher was a general lover of wisdom, whilst nowadays the growth of general culture has proceeded so far as to make people understand that with the general love no great results can be achieved. Whoever seeks wisdom must turn to science, which grows its fruit not in the hazy generality, but in concrete special fields. Philosophy, too, has become a special branch and has a special subject of study which is that of the "created mind."

To speak precisely: since Kant's time Philosophy has begun to recognise that its former efforts had been more or less of a youthful dream, and that it must, like all other scientific branches, set before itself a definite aim if it is at all to arrive at some sort of result. Philosophy has since then become gradually modernised and has now finally settled down to a critique of cognition. 
The created mind or the mental organ which has hen implanted by Nature in the head of man, has always puzzled him as a mystery. The solution of this mystery has been effected by the observation that all things, all natural phenomena are mysterious as long as they are not understood, not investigated. The more intimately man gets acquainted with them, the more they lose their mysterious character. The mind is no exception to this rule. Since Philosophy has consciously, clearly and definitely occupied itself with it, the mysterious unknown has become more known and has acquired quite a different complexion.

Just as the fetishists deify the commonest things stones and pieces of wood - so has the "created mind," too, been deified and wrapt in mystery - first by religion and afterwards by Philosophy. What religion used to call belief and supernatural world, was called by Philosophy metaphysics. Still we must acknowledge that the latter had for its laudable object to make of its study a science, - an aim which, indeed, it has finally achieved in a physical manner. Behind its own back there has arisen out of the metaphysical world-wisdom the special science of a modest theory of cognition.

Nevertheless we do not wish to give the philosophers too much credit for that. The mind saw scientific light not merely through philosophical heads; investigators of natural science, too, have at least indirectly, contributed something towards its elucidation. By enlightening the human mind in respect to other subjects science prepared the ground for, and provided the possibility of, an epistemological enlightenment. Before Philosophy could enter the innermost of the mind-function, it had to be shown by the practical achievements of natural science how the mental instrument of man possesses the hitherto 
doubted faculty of illuminating the innermost of Nature. The physicists do not close their eyes to the fact that there are many unknown worlds. Still some of them have yet to learn that the Unknown, too, is not so totally unknown and mysterious. Even the most unknown world and the most mysterious things are together with the known places and objects of one and the same category, namely, of the universal union of Nature. Owing to the conception of the Universe virtually existing, as a kind of an innate idea, in the human mind, the latter knows a priori that all things, the heavenly bodies included, exist in the Universe and are of universal, common nature. The "created mind" proves no exception to this scientific law.

The old religious world of ideas renders difficult the recognition of the truth that Nature is not only a nominal but an actual monas which has neither above it, nor in it, nor alongside of it anything else,- not an uncreated mind, either. The belief in an uncreated, monstrous, religious mind impedes the conception that the human mind itself has been created and produced by Nature - consequently is her own child towards which she knows no reserve. And yet Nature is reserved,- she never discloses her secrets all at a time or completely. She cannot give herself away entirely because she is inexhaustible in her treasures. Still the created mind, the child of Nature, is a lamp which illuminates not only the outermost, but also the innermost of Nature. In view of the physically endless and inexhaustible and all-embracing Nature such expressions as Innermost and Outermost must be regarded as antiquated conceptions. The same holds true of the term "created mind" insofar as this expression suggests an uncreated great, monstrous, metaphysical spirit which has its seat beyond the clouds. 
The "great spirit" of religion is the cause of the disparagement of the human mind of which the poet is guilty when he denies to it the capacity of penetrating into the "Innermost of Nature." And at the same time the uncreated monstrous spirit is but a fantastical reflex of the naturally produced human mind.

The theory of cognition in its most developed stage is able to prove this proposition up to the hilt. It has shown to us that the created mind derives all its ideas, conceptions and thoughts from the monistic world which science calls the "physical world." The created mind is the definite child of the world. Good mother Nature gave to it something of her inexhaustibility. Mind is as limitless and inexhaustible in gaining knowledge as $\mathrm{Na}$ ture is in her readiness to open her breast. The child is only limited by the limitless wealth of its mother's love, - it cannot exhaust the inexhaustible. The created mind penetrates with its science into the innermost of Nature. but it cannot penetrate beyond that,- - not because it is a narrowly limited mind, but because its mother is InfiniteNature, a natural infinity having nothing besides it.

The wonderful mother gave its child consciousness as an inheritance. The created mind comes into the world with the faculty of becoming conscious that it is the child of its good mother Nature which created for it the ability to form excellent images of all other children of its mother, of all its brothers and sisters. Thus the "created mind" possesses images, ideas, notions of air, water, earth, fire, etc., and at the same time the consciousness that these pictures which it had formed, are each true and adequate images. No doubt, the mind finds by experience that the children of Nature are changeable, that, for instance, water consists of various kinds of waters of which no drop is absolutely like the other; but 
that much it has inherited from its mother: to know by its own nature and a priori that water cannot alter its general nature without ceasing to be water and without losing all sense; it therefore knows, so to speak, prophetically that however much things may change, their general nature, their general essence cannot change. The created mind can never know all the possibilities and impossibilities of its uncreated mother; but that water is under all circumstances wet, or that mind, be it even met with beyond the clouds, cannot change its general nature, - this the created mind knows apodictically and of its own innate nature. The created mind, child of nature that it is, possesses the innate faculty of knowing that reason must be rational, that nature must be natural, that water must be liquid and that the uncreated spirit must be a monstrous absurdity.

The above may seem to be a mere assertion without proof. Yet, since every reader carries about with him the proof of these facts in his head, I may be spared the trouble to bring proofs from other quarters. One need only ask his own head whether it does not know prophetically that if there be a reason on the moon that reason may be smaller or greater than that of Peter or Paul, but must, in spite of all possible variations, remain as regards its magnitude and power within certain reasonable limits.

The knowledge of the "created mind," accumulated in the course of centuries by Philosophy and Science, culminates in the doctrine that this mind is a force, a force of nature, like that of gravitation, like heat, light, electricity, etc., and that alongside of its general nature, it possesses, like all other forces, a special nature of its own which distinguishes it from all other forces and makes it knowable. If we closely examine this special nature of 
the "created mind," we find that it possesses an innate, and, if you like, "wonderful" faculty of knowing with perfect sureness and without further inquiries that two mountains must have a valley between them, that a part is smaller than the whole, that circles are not square and that bears are not elephants. This wonderful faculty of the mind deserves every notice, since from it follows the further positive knowledge that the idea of another mind, besides the familiar human mind,- the idea of a mind which is above all known minds, is an extravagant idea, an ideological extravagance.

The created mind has inherited from its mother Nature the faculty, developed by experience, to classify the other creatures of nature, to distinguish and to name them. Thus it distinguishes the beech from the oak, the bears from the elephants; it classifies the world and is convinced that such classification is justified, and true, clear, and distinct. That this classification is subject to development and, consequently, to certain modifications, to limited changes, does not alter, and is no contradiction of, the fact that on the whole the classification made by the human mind is a well-defined, stable and durable one. From this it follows that what is called in New York bread may be called in Paris $d u$ pain, that is, bread may change its name, but it always and everywhere remains bread. It may also be of various kinds, forms and tints and be made of various kinds of flour, but these forms cannot alter its essence. The oak may be of different varieties, but it cannot vary beyond the limits of its species. The same with bears: there are large and small, brown and black, but there can be none which drop out of their species entirely.

Such knowledge is supplied to us through the objective research of the "creative mind." 
We refer to these facts in order to make it clear that we are as sure in this respect with regard to the mind as we are with regard to bread, oak or bear. There may be on other planets many minds which we do not know, but on the whole, according to their species they cannot be constituted differently from those "created minds" which we know, without dropping out not only from the name, but also from the conception. The supernatural mind is a fantastic conception.

Just as fantastical is also the conception of Nature by those who speak of a Nature which shuts her innermost against the "creative mind." Nature is the Unlimited. Those who grasp this grasp also that with reference to her there can be no question of beginning and end, of the above and below, of the innermost and outermost. All these terms do not refer to Nature in general, which is the absolute, but merely to her parts, to her products, the single things.

With our hands we only grasp the tangible, with our eyes only the visible, etc., but with our conception we grasp the whole Nature, the Universe. With all that our faculty of conception need not be conceited and look down on the senses as on something quite inferior and limited. That faculty, innate in the human head, would as little be able to form a conception without the aid of the senses as would the eye to see, the ears to hear, the hands to touch without the assistance of the mind. Just as the whole depends on the particulars, so all particulars depend on the Nature as a whole.

If we wish to form a concrete picture of Nature and its created mind we must, above all, infuse the latter with the consciousness that it must not raise itself above the mother as it did when it dreamt of a super- and extra-natural mind. $\bar{A}$ proper conception of the human 
mind, a conception which thinks of this piece of Nature neither extravagantly, nor disparagingly, but exactly,such a conception can only be gained if we become possessed of the clear and distinct consciousness of the universality of Nature. Then we perceive that the mysterious character which was ascribed to her, is a fancy. We see then and learn from experience how frankly universal Nature goes about her work. Our mind is her own product. She endowed it with the faculty and mission to gain knowledge of her and of all her phenomena. I say " of all" and use the term in a reasonable and moderate sense of the word, without failing to consider that Nature is inexhaustible in the production of her phenomena, and that the "created mind," so far as it is but a piece of Nature, can, in spite of its universality in conceiving, only be a limited creature of $\mathrm{Na}$ ture.

Do we not possess a sense of touch which feels everything tangible? Maybe, that there is an animal whose feelers are still more delicate than the nerves of the human skin. Have we on that account cause to complain of our limited sense of touch or of the inadequacy of $\mathrm{Na}$ ture? Perhaps, we should have, if she had not endowed us with a mind which is inventive enough to acquire instruments by whose means we can discover things inaccessible to the most delicate feelers.

In short, whoever considers the results of natural science cannot accuse Nature of a mysterious reservedness, and whoever at the same time takes stock of the results of Philosophy cannot fail to notice that the human mind is called upon to solve all possible problems. But the Impossible has neither sense nor reason and must not therefore form the object of our observation and attention. 
What did we say? The Impossible had neither sense nor reason? Are we to postulate reason in something else besides the human head? Are we not, we human beings, the highest ones to possess a mind, reason, understanding, a faculty of cognition? The latter being the special subject of this chapter, we may as well deal with the question now.

Just as the faculty of seeing is connected organically with light and color, or the subjective sense of touch with tangible objects, so also is the created mind connected with the riddle of Nature. Without comprehensible things in the external world there can really be no understanding inside the head. To have missed this interrelation of things was the fault of those backward epistemologists who have such hazy notions of mind and Nature that they seek for a solution beyond the clouds.

The exaggerated disparagement of the mind which is said not to be able to illuminate the innermost of Nature, just as the exaggerated mystification of Nature whose innermost is said to be impenetrable - both arise out of a method of thinking which for thousands of years has, like a natural growth, dominated mankind. This has now changed; the efforts of philosophy have now succeeded at last in making man the master of his way of thinking, - at least in so far as to be able to solve the problems, which are confronting him, with more skill and method.

Philosophy has discovered the art of thinking. That it has thereby occupied itself so much with the all-perfect Being, with the conception of God, with the "Substance" of Spinoza, with the "thing in itself" of Kant, and with the "Absolute" of Hegel, has its good reason in the fact that the sober conception of the Universe as of the All-One with nothing above or outside or alongside of 
it, is the first postulate of a skilled and consistent mode of thinking, which knows both of itself and of all possible and impossible objects that they all belong to one eternal and limitless union which is called by us Cosmos, Nature and Universe.

We think to have proved thereby that a higher mind than the human one is not possible. My mind and thine are limited minds because they are only parts and fragments of the human mind in general. The minds of men are connected with one another, one supplements the other, one learns from the other, and this connection forms the progressive, developing process of the mind of the species. "On the tree of mankind blossoms sprout and throng upon blossoms." How high that tree may grow yet, we do not know; but that it will not grow right into heaven - that we know a priori, positively, apodictically.

We, therefore, on the one hand, assert, we do not know what is possible for Nature to accomplish. She may yet in the long run bring out wonderful things such as no imagination could ever have dreamt of. And yet we assert, on the other hand, that we know apodictically what is impossible.

How, then, does it stand with this contradictory knowledge of the Possible and Impossible?

Quite simply; our undoubted knowledge of the impossibility of a supernatural, uncreated mind rests on the critique of reason which is also called by another name: theory of cognition. This branch of study has selected as its special object of inquiry the empirical mind and has found out that the mind possesses the undoubted conviction of the universality of Nature, that the consciousness of unity, infinity and immensity is innate in it, at least as a predisposition. 
The parson was already convinced that his divine omnipotence can do nothing bad. Why should we not be convinced that the natural omnipotence, the creator of the human reason, can not have created anything irrational, illogical? There is, of course, enough irrationality in Nature, that is, enough which is comparatively or secondarily irrational. But of such irrationality as would completely and absolutely overstep the boundaries of its kind, we cannot even conceive,- Nature simply does not permit it to our faculty of thinking. She has endowed our mind with the conviction that she cannot be irrational and illogical to such an extent.

The omnipotent Nature has created Reason and implanted in it the consciousness that her omnipotence is a rational force which cannot be so illogical as to create minds or beings which are still more omnipotent than the natural omnipotence. It is a law of natural logic and logical nature that everything must remain within the natural species, that though species and varieties may change, yet not so extravagantly as to outgrow the general species, the natural. There can, therefore, be no mind which should penetrate so.deeply into the innermost of Nature as to be able to clasp her and pocket her, as it were.

Is this certainty, given to us by Nature, wonderful? Is it inexplicable that the thinking fragment of Nature should possess from its mother the conviction that the omnipotence of Nature is a rational omnipotence? Would it not have been more inexplicable if the child of its mother were compelled to think that the latter is omnipotent and omnipresent in an irrational sense?

Yes, Nature is in every respect wonderful whether we contemplate her in a superficial manner or penetrate into her innermost recesses. But withal, her natural 


\section{EXCURSIONS INTO THE DOMAIN OF EPISTEMOLOGY 277}

wonderfulness is explicable. Still more wonderful, however, are the people who dream of an intellect wonderful beyond all measure, in comparison with which the wonderfulness of Nature would be trivial. 
THE ABSOLUTE TRUTH AND ITS NATURAL MANIFESTATIONS.

Was it Goethe or Heine? It is one or the other who said: only the know- and have-nots are modest. I repudiate, accordingly, all such modesty because I believe myself in a position to make a small contribution to the great work of science. I am strengthened in this belief by the May number of the Neue Zeit (1886), where my efforts are honorably mentioned by our highly meritorious Frederic Engels in an article on Ludwig Feuerbach. In such cases the personal and objective elements are so closely bound up with one another that an exaggerated modesty can only hinder the progress of the objective inquiry.

The things which I am going to discuss here were already set forth by me some seventeen years ago in an opuscle which then appeared. Yet what I said at that time is so scanty that in view of the progress since made on the subject I feel justified in returning to it once more. Already Hegel said in his preface to the "Phenomenology of Mind" quite aptly: "The easiest thing is to judge what has substance and solidity; more difficult is to conceive it ; and most difficult of all, because it must contain both judgment and conception, is to reproduce it by description." In fully endorsing these words I forbear to give an adequate presentation of the case now before me; all I should attempt here is to sketch the essence of the cherished epistemological question, which $I$ have in 
my mind, in all brevity and with as much precision as I can command. I hope that the task thus defined may justify me in explaining in a few words - by way of elucidating the subject - how I came across it.

The year 1848 with its reactionaries, constitutionalists, democrats and socialists called forth in my then youthful mind an irresistible desire to acquire a critically firm, undoubted standpoint, a positive opinion as to what in all that I had heard and read for and against was absolutely and unmistakably true, good and right. As I had my just doubts about God in heavens, and the church did not inspire me with any confidence at all, I found myself amidst the greatest perplexity, not knowing how to escape from the situation. While on search I came across Ludwig Feuerbach, and the diligent study of his writings gave me a good push forward. Of still greater help in my thirst for knowledge was the "Communist Manifesto," which I got to know through the newspapers on the occasion of the trial of the Communists at Cologne (1849). Most of all, however, I owe, after a number of old philosophical volumes had in the meanwhile appeared in my rural life, to the work of Marx which appeared in I859 under the title: "A Contribution to the Critique of Political Economy." There it is stated in the preface that the way - so approximately runs the sentence - in which man earns his daily bread, that the level of civilisation on which a generation physically works, determines the mental standpoint or the way in which it conceives and must conceive the True, the Good and Right, God, Freedom and Immortality, Philosophy, Politics and Law.

Everything that I have studied and read all my life referred to one point which I desired and made mental efforts to grasp, viz.: how to attain a positive, undoubted knowledge, that is, to a criterion of what is true and 
right. The above passage leads us to the true path which shows how it altogether stands with human knowledge and with the absolute and relative truth.

What I have just related as a personal experience is the experience which mankind, too, has made in the course of centuries. If I had been the first to moot these questions and to exhibit the thirst for the absolute truth, I would have been the fool to wait for an answer in all eternity. The fact, however, that I was not left such a fool, but received a sufficient answer, is due to the historical development of things which made me put the questions at a time when after a long series of preceding generations the best minds had occupied themselves with their solution and could already supply me with such elucidation as I obtained, in point of fact, from Feuerbach and Marx. What I mean to say by this is, the light which those men gave me was not merely the product of these individuals, but it was the common product of culture older than the historical times.

At first sight it seems as if there was little agreement among the predecessors,- - who, begining with the Greek Thales and ending with the Prussian Jürgen Bona Meyer at Bonn, have enquired after the absolute truth. A closer examination, however, will reveal the red line which, running from generation to generation, becomes ever more distinct and patent. It is the lack of appreciation of the importance of the historical which even now misleads some people to look in the innermost of their heads for that enlightenment which with a little more historical sense they would have found in the products matured in the gradual development of science through the long period of centuries.

But to the point. By way of reply to the question, what is truth, absolute truth, Pilate shrugged his shoul- 
ders as if to say, that is too high for me,- - go and ask the High-Priest Caiaphas. The latter then said the same which priests say to this day: God is truth,- it is supernatural, super-earthly. It is not worth while at the close of the nineteenth century to trouble myself with the refutation of such an answer. On the other hand, Pilates are still too numerously represented even among the leaders of science to hinder a rational enlightenment on that point.

To understand more clearly the nature of the absolute truth it is first of all necessary to do away with the oldrooted prejudice which regards it as of a purely mental nature. No, no! Absolute truth can be seen, heard, smelt, touched and, of course, also known; but it cannot be resolved into pure knowledge,- it is not pure mind. Its nature is not either corporeal, or mental, not one or the other, but all embracing, as much corporeal as spiritual. Absolute truth has no nature of its own, but, on the contrary, it has the nature of the general. In other words, to speak without mystification, the general natural nature and general truth are identical. There are no two Natures, one corporeal and another a mental. There is only one Nature which contains all bodies and all minds.

The Universe is identical with Nature, with the world and the absolute truth. Natural science divides Nature into parts, domains, branches of study, but it knows and feels that all such divisions are formal only, that Nature or Universe is in spite of all divisions undivided,- in spite of all variety and manifold natures only one indivisible, general and universal Nature, World and Truth. There is only one Existence, and all forms are modi, varieties or relative truths of one general truth which is absolute, eternal and endless at all times, in all places. 
Human knowledge is, like anything else, a limited portion of the unlimited, a modus, a variety of Existence or General Truth.

Since the nature of truth has hitherto been regarded as purely mental, and accordingly, truth was looked upon as a thing which is only to be found in knowledge, the inquiry into human knowledge comes within the province of our subject, of our search after the absolute and relative truth and their relation.

The mental world of man, that is, all we know, believe and think, forms a portion of the universal world which only in its absolute inter-relation, in its complete whole possesses an unlimited, perfect, absolute existence, a true one in the highest sense of the word. At the same time it possesses through its component parts, modi, varieties. products or phenomena an infinite number of existences of which every particular one is also true, but is as against the whole a mere relative truth.

Human knowledge, itself a relative truth, is the medium between us and the other phenomena or relativities of the absolute Existence. Still the faculty of cognition, the knowing subject, must be distinguished from the object, the distinction being, however, a limited and relative one, since both the subject and the object are not only distinct, but at the same time alike in that they are parts or phenomena of the same generality called the Universe. We distinguish between Nature and parts, departments or phenomena, though these are inseparably connected with the All-Existence, emerge from it and submerge in it. There is no Nature without phenomena, her manifestations, nor phenomena without Nature, as the Absolute. It is only our knowledge which provides the separation, the mental analysis in order to form an image of the phenomena. Knowledge, conscious of its doings and 
dealings, must know that the mentally separated, differentiated objects are indivisibly bound up with the reality of Nature.

What we learn to know are truths, relative truths or natural phenomena. Nature itself, the absolute truth. cannot be known, - not directly, but only through her manifestations, the phenomena. How then do we know that there is behind the phenomenon an absolute Truth, a general Nature? Is this not a new mysticism?

Well, let us see. As human knowledge is not the absolute truth, but only an artist making pictures of the truth, true, genuine, correct and exact pictures, it is selfevident that the picture does not exhaust the object and that the artist cannot reach the comprehensiveness of the model. Nothing more insipid has ever been said of truth and knowledge than what has been repeated for thousands of years by the commonly accepted logic, namely, that truth is the conformity of our knowledge with its object. How can a picture "conform" with its model? Approximately it can. What picture worth the name does not agree approximately with its object? Every portrait is more or less of a likeness. But to be altogether alike, quite the same as the original - what an abnormal idea!

Thus we can only know Nature and her parts relatively, since even a part, though only a relation of $\mathrm{Na}$ ture, possesses again the characteristics of the Absolute, the nature of the All-Existence which cannot be exhausted by knowledge.

How, then, do we know that behind the phenomena of Nature, behind the relative truths, there is a universal, unlimited, absolute Nature which does not reveal itself completely to man? Our vision is limited, so are also our hr "ng, touch, etc., and our knowledge; yet we know of 
all these things that they are limited parts of the Unlimited. Whence that knowledge?

It is innate; it is given to us with consciousness. The consciousness of man is the knowledge of his personality as part of the human species, of mankind and of the Universe. To know is to form pictures in the consciousness that they are pictures of things which all, both the pictures and the things, possess a general mother from which they have issued and to which they will return. This mother is the absolute truth; she is perfectly true and yet mystical in a natural way, that is, she is the inexhaustible source of knowledge and consequently never entirely to be comprehended.

All that is known in and of the world is, however true and exact, only a known truth, therefore a modified truth, a modus or part of truth. When I say that the consciousness of the endless, absolute truth is innate in us, is one and the only knowledge a priori, I am confirmed in my statement also by the experience of this innate consciousness. We learn that every beginning and end are only a relative beginning and end, at the bottom of which lies the Inexhaustible by all experience, the $\mathrm{Ab}$ solute. We learn by experience that each experience is only a part of that which, in the words of Kant, surpasses all experience.

The mystic of a fantastical character will, perhaps, say: then, there is something after all which surpasses the limits of physical experience. We reply, yes and no at the same time. In the sense of the old exaggerating metaphysician, there is nothing of this kind. In the sense of the cognition conscious of its nature, each particle, be it of dust or of stone or of wood, is incomprehensible as to its whole extent, each particle being an inexhaustible material for the human faculty of cognition, 
consequently something which surpasses all experience.

When I say that the consciousness of the absence of a beginning and end of the physical world is an innate consciousness which is not acquired by experience, - in other words, that it is a consciousness which is given $a$ priori and precedes all experience, I must still add, that originally it is only given as a germ and that it has developed to what it is now through experience in the struggle for existence and through sexual selection.

In so far the knowledge of the Universe as the absolute truth is, too, an empirical knowledge which, just like every other knowledge and like every other thing, is given a priori as a germ and originates in the Endlessness. Hence it follows that the human mind, which has clearly conceived the relation between the universal truth and the natural phenomena, will no longer separate in an exaggerated way the knowledge gained by experience from the innate faculty of knowledge, cognition, etc.

Mysticism of this kind is not of the nebulous, morbid sort such as the one which teaches us that the human faculty of cognition is too narrow to know the absolute truth. The human intellect is too small to exhaust by study the smallest particle as well as the whole of $\mathrm{Na}$ ture. But since such inexhaustibility or endlessness is a predicate which applies to all things without exception, and consequently, to our faculty of cognition also, it is sheer humbug to make much capital out of it as was the custom until now.

Morbid mysticism separates unscientifically the absolute truth from the relative truth. It makes of the phenomenal thing and of the "thing in itself," that is, of the phenomenon and truth, two categories which differ completely from each other and are not contained in one united category. This nebulous mysticism turns our 
knowledge and faculty of cognition into mere substitutes which have to suggest to us a superhuman monstrous mind somewhere in the transcendental heavens.

Humility is always becoming to man. Yet the statement of the inability of man to know the truth has a double sense,- one that is worthy and one that is unworthy of man. Everything which we know, all scientific results, all phenomena are parts of the genuine, the right, the absolute truth. Though the latter is inexhaustible and cannot with full perfection be portrayed in knowledge or pictured in the mind, yet the pictures, which science is able to show of it, are exact pictures in the humanly relative sense of the word. Just so the sentences which I am now writing down here have an exact, rational sense and yet have not, if one likes to pervert or misunderstand them.

Granted that truth cannot be exhausted by knowledge. Still it is not so far removed from our cognition as the fantastical mystics assume who are not satisfied with the human mind, because they carry about in their head the fantasy of a superhuman monstrous mind.

Scientific cognition must not long after absolute truth because that truth is given to us by means of our senses as well as of our mind without further search. It is in reality the phenomena, the special manifestations of the given general truth, which we want to know. Such truth readily yields itself to us in its particular phenomenon. It is exact pictures, genuine knowledge which our cognition has to provide. And the question here deals only with relative exactness or completeness. More must not be wished for by human reason. This is no resignation as the monks recommend. We are able to know the truth - it yields to us readily. But it is quite natural that we cannot jump out of our skin. It may also be 
natural that there should be metaphysical and religious dreamers who still go about with such an intention. Their quest after another absolute truth is a dream which the history of human knowledge has left far behind it, whilst the modesty which is satisfied with the knowledge of relative truth is called rational enlightenment.

Spinoza says, there is only one substance,- - it is universal, endless or absolute. All other finite so-called substances originate in it, emerge from it and submerge in it; they only have a relative, transient, accidental existence. All finite things are to Spinoza, and justly so, mere modi of the endless substance, as confirmed by our modern natural science in its doctrine of the eternity of matter and conservation of force. Only in one thing, and that a very essential one, Spinoza had to be corrected by the subsequent philosophy.

According to Spinoza, the endless, absolute substance possesses two attributes: it is infinitely extended and it thinks infinitely. Thought and extension are the two Spinozist attributes of the absolute substance. This is wrong, especially as there is nothing which could support the proposition of the absolute thinking. And the absolute extension, too, explains very little. The world, or the absolute, or Nature, or the Universe, or whatever else the thing of things, the One and Infinite is called, extend infinitely both in time and space; yet every little space of the Space, and every particle of Time as well as every other thing which is contained in it, is an individual, changeable, transient, limited thing, and thinking forms no exception to this limitation and finity.

Our present knowledge of the nature of thought and thinking far surpasses that of Spinoza in clearness and definiteness. We now know that thinking or consciousness is no mysterious depository of truth, but rather in 
its true nature possesses no other nature than the natural one of which all other things participate. It is as murh trivial as mysterious, and, though an unlimited object of study, yet no more unlimited than any other particular matter or force.

What is called by Spinoza the endless substance, and what we call the Universe or the absolute truth, is as identical with its finite phenomena, with the relative truths which we meet in the Universe, as the forest is identical with its trees, or in general, as the species with its varieties. The relative and the absolute do not lie so far apart as it is painted to man by that uncultivated sense of infinity which is called Religion. And the branch of study, too, which is called speculative Philosophy was permeated by religion and proceeded from that ignorance which did not perceive the relative position of the human mind to the absolute truth. The branch of study which strove after a clear idea of the mind was from its beginning to the very last classical philosophers biased by inconsistent extravagance. It fails to perceive that everything which is relative, and the faculty of cognition, too, is contained in the Absolute precisely in the same way I repeat the analogy - as trees are contained in the forest. It misses the essence of all logic, viz., that all specialties without any exception are contained in one species and all species in one general species, the Universe, which is the absolute truth.

Philosophy, like Religion, lived in the belief in a supernatural absolute truth. The solution of the problem lies in the conception that the absolute truth is nothing but the generalized truth, that the latter dwells not in the mind - at least, not more than anywhere else - but in the object contemplated by the mind, which we designate by the general term, the Universe. 
The transcendental absolute truth which Religion and Philosophy used to call God, was a mystification of the human mind which in its turn mystified itself with this fantastical picture. The philosopher Kant, who dealt with the critique of the faculty of cognition, found out that man cannot know the transcendental absolute truth. We may add: man cannot know the prosaic, every-day things, either, in a transcendental absolute manner. When, however, he uses his faculty in a sober and relative way as one has to consider all circumstances relatively, as soon as he rids himself of his supernatural bias, then everything is to him open and nothing closed, and he can also grasp and know the general truth.

Just as our eye, be it with the assistance of glasses, can see everything and yet not everything, since it can neither see sounds nor smells, nor, in general, anything invisible, so our faculty of cognition can know everything and yet not everything. It cannot know the unknowable. But this is plainly enough only a fantastical or a transcendental desire.

When we recognize that the absolute truth which was sought by Religion and Philosophy in the region of the transcendental, is close at hand in its full reality as the bodily Universe, and that the human mind is a real, or actual and active part of the general truth, having the mission to form true pictures of the parts of the general truth, then we have the problem of the limited and unlimited completely solved. The Absolute and the Relative are not separated transcendentally, they are connected with each other so that the Unlimited is made up of an infinite number of finite limitations and each limited phenomenon possesses the nature of the Infinite.

How and in what way the things said here bear upon the passage from Marx quoted at the beginning, that 
is, upon the true, good and right in political and social life, I must leave meanwhile to the reader to find out for himself, as a detailed elucidation of it would take up too much space here. Perhaps, I may yet find the opportunity to return to that reference at another time. ${ }^{1}$

1 Find the explanation in the next chapter.-Eprroz. 


\section{MATERIALISM VERSUS MATERIALISM.}

“"The insight," says Frederic Engels, " gained into the utter perversity of the hitherto prevailing German idealism led necessarily to materialism, but, of course, not to the mere metaphysical materialism of the eighteenth century."

This modern materialism which is here derived from the total perversion of German idealism and of which Engels himself is one of the founders, is little understood, though it forms the fundamental basis of the theory of German Social-Democracy. We propose, therefore, to make it the subject of a somewhat detailed examination.

This specifically German, or, if you like, Social-Democratic materialism, can best be characterized by comparing it with the "metaphysical, exclusively mechanical materialism of the 18 th century;" and when we further confront it with the German idealism from the perversity of which it sprang, the character of the Social-Democratic basis, which, owing to its materialist name, is easily exposed to misrepresentation, must clearly reveal itself.

And first of all, why does Engels call the materialism of the I8th century "metaphysical?" Metaphysicians were people who were not satisfied with the physical or natural world, but always carried about the idea of a supernatural, metaphysical world. Kant in his preface to the "Critique of Pure Reason," sums up the problem 
of metaphysics in three words: God, Freedom and Immortality. One knows now that God was a spirit, a supernatural spirit, who created the natural, physical, material world. The celebrated materialists of the 18 th century were no friends or worshippers of this biblical story. The problem of God, Freedom and Immortality, so far as it refers to a supernatural world, left those atheists thoroughly indifferent. They stuck to the physical world and were so far no metaphysicians.

It is evident that Engels uses the word in a different sense.

Of the primary great mind beyond the clouds the French and English materialists of the 18th century had disposed completely enough ; but they could not help occupying themselves with the secondary human mind. It is the difference in the conception of this mind, its nature, its origin and its constitution which distinguishes the materialists from the idealists. The latter regard the human mind and its ideas as children of a supernatural, metaphysical world. Still they have not been content with the mere belief in such a distant origin, but rather strove, since the very days of Socrates and Plato, to supply this belief with a scientific basis, to prove it, to elucidate it, just as one proves and elucidates physical things of the tangible world. In this way the idealist brought the knowledge about the nature of the human mind down from the transcendental, metaphysical world to the real, physical, material world which reveals itself as a dialectical or evolutionary process, where mind and matter, though two, are yet one, that is, twin children springing from one blood, from one mother.

The idealists originally favored the religious notion that the world was created by a spirit. In this they were completely wrong, since it finally, as a result of their 
efforts, became evident that it is precisely the natural material world which is the original; that this was created by no spirit, but on the contrary, the natural or material world itself is the creator which brought forth and developed man with his intellect out of itself. Thus it was discovered that the supreme uncreated spirit is but a fantastical image of the natural mind which has developed in, and together with, the human nervous system and its brainy skull.

Idealism, which derives its name from the circumstance that it sets the idea and the ideas, those products of the human head, above and before the material world - both in point of time and importance, this idealism has started very extravagantly and metaphysically. In the course of its history, however, this extravagance has toned down and become more and more sober till Kant himself answered the question which he had set out to solve, viz.: "Is Metaphysics at all possible as a science?" in the negative; Metaphysics as a science is not possible; another world, that is, a transcendental world can only be believed and supposed. Thus the perversion of idealism has become already a thing of the past, and modern materialism is the result of the philosophical and also of the general scientific development.

Because the idealist perversity in its last representatives, namely Kant, Fichte, Schelling and Hegel, was thoroughly German, its issue, dialectical materialism, is also a preëminently German product.

Idealism derives the corporeal world from the mind, quite after the fashion of religion where the great spirit floats over the waters and has only to say: "Let there be," and it is. Such idealist derivation is metaphysical. Yet, as mentioned already, the last great representatives of German idealism were metaphysicians of a very mod- 
erate type. They had already emancipated themselves considerably from the transcendental, supernatural, heavenly mind,- not, however, from the spell-bound worship of the natural mind of the world. The Christians deified the mind, and the philosophers were still permeated to such an extent with this deification, that they were unable to relinquish it - even when the physical human mind had already become the sober object of their study making this intellect of ours the creator or parent of the material world. They never tire in their efforts to arrive at a clear understanding of the relation between our mental conceptions and the material things which are represented, conceived and thought.

To us, dialectical or Social-Democratic materialists, the mental faculty of thinking is a developed product of material Nature, whilst according to the German idealism the relation is quite the reverse. That is why Engels speaks of the perversity of this mode of thinking. The extravagant worship of the mind was the survival of the old metaphysics.

The English and French materialists of the I8th century were, so to speak, too hasty opponents of this sort of worship. This over-hastiness prevented them from emancipating themselves from it thoroughly. They were extravagantly radical and fell into the opposite perversity. Just as the philosophic idealists were worshipping the mind and the mental, so were the materialists worshipping the body and the corporeal. The idealist overestimated the idea, the materialist matter, both were dreamers and in so far metaphysicians, both distinguished mind and matter in a fantastic, unreal way. Neither of them raised themselves to the consciousness of unity and monism, generality and universality of Nature which is 
not either material or mental, but is one as well as the other.

The metaphysical materialists of the 18th century and their present followers - for there are still some of them among us - undervalue the human mind and the inquiry into the constitution and its proper use just as much as the idealists overvalue them. They, the materialists, proclaim, for instance, that the forces of Nature are properties of matter, and that especially the mental force, the force of thought, is the property of brain. Matter or the material, i. e., the ponderable and the tangible, is in their eyes the main thing in the world, the primary substance, while the mental energy, like all non-tangible energies, is but a secondary property. In other words, ponderable matter is to the old materialists the exalted subject, and all other things subordinate predicates.

There is in this mode of thinking an exaggeration of the importance of the subject and a disparagement of the predicate. The fact is lost sight of that the relation between the subject and the predicate is a variable one. The human mind may legitimately turn every predicate into a subject, and vice versa, every subject into a predicate. The snow-white color is, if not tangible, at least as substantial as the color-white snow. To think that matter is the substance or the main thing, and its predicates or properties are mere subordinate appendices, is an antiquated, narrow way of thinking which has taken no notice of the work of the German dialecticians. It must now be understood that subjects are composed exclusively of predicates.

The statement that thought is a secretion, a product of the brain, as bile is a secretion of the liver, tells us something that is unquestionable. Yet, it must be confessed that the analogy is a very bad, a faulty one. The liver, 
the subject of this observation, is something tangible and ponderable; likewise the bile which is said to be the predicate or the effect of the liver. In this illustration both the subject and the predicate, both the liver and the bile, are ponderable and tangible, and it is this circumstance which conceals what the materialists wish to convey when they represent the bile as the effect and the liver as the superior cause. We must therefore specially emphasize what in this case is not at all disputed, but what in the relation between the brain and mental energy is entirely lost sight of,- - namely, that the bile is not so much the effect of the liver as the effect of the life-process as a whole. In the life-process of human nature as in the cosmic life-process of the natural Universe the liver and the bile are of equal standing and equally subordinate, equally cause and equally effect, equally subject and equally predicate.

By saying that bile is a product of the liver the materialists do not in the least wish to deny that both are of equal value as subjects of scientific research. When, however, it is stated that consciousness, the faculty of cognition, is a property of the brain, the tangible subject appears to them as the sole object worthy of study, while the mental predicate is a mere settled thing as it were.

We call this mode of thinking of mechanical materialism narrow because it makes the tangible and the ponderable the subject, the depositary of all properties, and that to such an extent as to overlook entirely that in the Universe the transcendentally extolled palpability plays precisely the same subordinate predicative part as every other subordinate subject of General Nature.

The relation between subject and predicate explains neither matter nor thought. Still in order to elucidate the connection between the brain and the mental energy 
it is necessary to elucidate the connection between subject and predicate.

We shall, perhaps, come nearer to the point, if we select another example, an example where the subject is material, but the predicate is such as makes it at least doubtful, whether it is material or mental. If, for instance, the legs walk, the eyes see, the ears hear, it is questionable whether the subject and its predicate belong together to the domain of the material; whether the light which is seen, the sound which is heard, and the movement which is effected by the legs are something material or immaterial. The eyes, ears, and legs are tangible and ponderable subjects, while the predicates - vision and its light, hearing and its sound, movement and its steps (apart from the legs which do the pacing) can neither be touched nor weighed.

Now, how great or small is the conception of matter? Do colors, light, sound, space, time, heat and electricity belong to it, or must we relegate them to a different category? With the formal distinction between subjects and predicates, things and properties, causes and effects, the question is by no means disposed of. When the eye sees, the palpable eye is, of course, the subject. But one is also justified to reverse the expression and to say, that the imponderable vision, the forces of light and vision are the main things, the subjects, while the material eye is a mere instrument, a secondary thing, attribute or predicate.

So much is evident: matter has no greater importance than the forces, and the forces have no greater importance than matter. Materialism is narrow when it gives matter the preference and waxes in enthusiasm over the material at the expense of the forces. Those who assume the forces to be mere properties or predicates of matter 
are badly informed of the relativity, or the variability of the difference between substance and property.

The conception of matter and the material has hitherto been very confused. Just as the lawyers cannot agree as to the first day of life of the child in the womb, or as the philologists continually dispute what is to be taken as the beginning of speech, whether the alluring cries and love songs of birds are speech or not, or whether speech by mimics or gestures are of the same category as vocal speech, so also do the materialists of the old school continually dispute as to what is matter,- whether it is merely the tangible and ponderable which ought to be regarded as such, or also the visible, smellable, audible and finally the whole Nature, including even the human mind which is also an object of study, namely, of epistemology.

We see, the distinguishing mark between the mechanical materialists of the I8th century and the Social-Democratic materialists trained in German idealism consists in that the latter have extended the former's narrow conception of matter as consisting exclusively of the Tangible to all phenomena that occur in the world.

There is nothing to say against the transcendental materialists distinguishing between the tangible and ponderable, on the one hand, and the smellable, audible and visible and even the world of thought, on the other. We only object to their carrying this distinction beyond reasonable bounds, failing thereby to see the common and kindred nature of things or properties, - in other words, we object to their distinction becoming metaphysical, thereby missing the significance of the common category which embraces all opposites and contrasts.

The old materialists dealt in irreconcilable opposites just like the perverted idealists. Both place cognition 
and its material too far from each other, they magnify the opposition in an unnatural manner, and that is why Engels calls their mode of thinking "metaphysical." An example to illustrate this is the common way of thinking which forgets that death which concludes life is but an act of life and stands in the same connected relation with life as might be seen in the opposition between word and deed where a little thought will show that word is, after all, deed too - words are ideas embodied by an act of will - thus confirming our view that "metaphysical" distinctions are inadmissible.

Modern science is even to-day still animated by the bias of the materialists of the 18 th century. These materialists were the general theoreticians, the philosophers of natural science, so to speak, in so far as the latter confines its study to the mechanical, that is the palpable, the ponderable and tangible. Natural science, of course, has begun long since to overstep these limits. Already Chemistry has led beyond the narrow boundaries of the mechanical, and the same is now being done in Physics by the theory of the conservation and transformation of energy. With all that, however, science is narrow and wanting in penetration, it still lacks a systematic theory of the Universe as an infinite monistic evolutionary process. The study of the human mind and of all those relations which cognition has effected in human history, that is, the things political, judicial, economical, etc., all this natural science excludes from its province, still laboring under the delusion that mind is something metaphysical, is a child of another world and not subject to the laws governing the Universe.

Science deserves that reproach not because it separates the mechanical, chemical, electro-technical and other knowledge from one another and constitutes them special 
branches; this is quite legitimate; our reproach is only directed against the metaphysical mode of thinking in which science is caught, as it were, in a straight-jacket, as is evidenced by its hard and fast distinctions and by its absolute separation of matter from mind. It is only in so far as it does not perceive that Politics, Logic, History, Law, and Economics - in short, all mental relations are natural and scientific relations, that it together with the mechanical materialists and the German idealists still remains in the metaphysical, that is in the transcendental stage.

It is not what one thinks of the stars or animals, plants or stones that distinguishes materialists from idealists; the characteristic point is solely and only the respective view of the relation between body and mind.

The insight into the total perversity of German idealism which would not desist from regarding mind as a metaphysical primus creating all tangible, visible, audible and other phenomena, led necessarily to the Socialist Materialism which is called "Socialist" because it was the Socialists Marx and Engels who first enunciated clearly and distinctly that the material, that is, the economic conditions of human society form the basis from which the entire superstructure of the juridical and political institutions as well as the religious, philosophical and other modes of thought are at each historical epoch in the last instance explained. Instead of explaining, as hitherto, the existence of man out of his consciousness, it is now, on the contrary, the consciousness which is to be explained out of his existence, that is, from the economic position, from the way and manner of bread-winning.

The Socialist materialism understands by matter not only the ponderable and tangible, but the whole real existence. Everything that is contained in the Universe - 
and in it is contaned everything, the All and the Universe being but two names for one thing - everything this Socialist materialism embraces in one conception, one name, one category, whether that category be called the actuality, reality, Nature or matter.

We, modern Socialists, are not of the narrow opinion that the ponderable and tangible matter is matter par excellence. We hold that the scent of flowers, sounds and smells are also material. We do not conceive the forces as mere appendices, mere predicates of matter, and matter, the tangible one as "the thing" which dominates over all properties. Our conception of matter and force is, so to speak, democratic. One is of the same value as the other; everything individual is but the property, appendix, predicate or attribute of the entire Nature as a whole. The brain is not the matador and the mental functions are not the subordinate servants. No, we modern materialists assert that the function is as much and as little an independent thing as the tangible brain-mass or any other materiality. The thoughts, too, their origin and nature, are just as real matters and materials worthy of study as any.

We are materialists because we do not make of mind a metaphysical monstrosity. The force of thinking is to us just as little a "thing in itself" as gravity or a clod. All things are merely links of the great universal connection which alone is durable, true, subsisting and thus more than a phenomenon, indeed, the only "thing in itself" and the absolute truth.

Because we Socialist materialists have only one interrelated conception of matter and mind, the so-called mental relations such as those of politics, religion, morals, etc., are to us also material conditions; and material labor and the bread-and-butter question are only in so far 
regarded by us as the basis, the perquisite and foundation of all mental development as the animal element is prior in point of time to the human one - which does not prevent us from valuing man and his intellect very highly.

Socialist materialism is distinguished by the fact that it does not undervalue the human mind as the old materialists did, nor over-value it as the German idealists did. It proceeds in its appreciation in a moderate manner and regards both Mechanics and Philosophy from the standpoint of critical dialectics, namely as interrelated phenomena of the inseparable world-process and world-prog, ress.

In his "General Morphology" Ernst Haeckel says: "The general and rapid advancement made by Geology and Botany in consequence of the extraordinary services rendered by Linnæus to the systematic knowledge of animals and plants, led to the erroneous assumption that the systems themselves were the aim of science and that it was only necessary to enrich the system with as many new forms as possible in order to render durable service to the cause of zoological and botanical sciences. It was thus that there arose the great and melancholy host of zoologists of the Museum and botanists of the Herbarium who could distinguish by their names each of the thousands of species, but at the same time had not the slightest knowledge of the rougher and more delicate structural conditions of these species, of their development and life-history, of their physiological and anatomical conditions. . . . We must, however, point out the singular delusion under which modern Biology labors when it advertises in glowing terms as scientific Zoology and scientific Botany the bare mechanical description of the inner and delicate, especially microscopical, form-rela- 
tions and compares this, not without pride, with the pure description of the external and rougher form-relations, which was exclusively prevalent in former times and which is the chief occupation of the so-called systematizers. As long as these two schools, which are fond of contrasting themselves so sharply, are aiming at description only (whether of the external or internal, the delicate or the rougher forms, does not matter) the one is worth just as much as the other. Both of them can only rise to the level of science when they try to explain the form and trace the law underlying it. In our firm conviction, the reaction which was sooner or later bound to come against this totally one-sided and narrow empiricism, has in fact already begun. Darwin's discovery, given to the world in 1859 , of the natural selection in the struggle for existence - one of the greatest discoveries of the human mind - has with one stroke turned such a fierce and clear light upon the obscure mass of the gradually accumulated biological facts that even the most obstinate empiricists - if they wish to keep pace with science at all - will in future no longer be able to avoid the new Natural Philosophy which arose as a consequence of it."

We quote these words of Haeckel, one of the most renowned naturalists of the time, to show what his attitude is to the old question: what is science? What must we do in order to understand, to study, to explain stones, plants, animals, men and human instincts? Man possesses in his head an active faculty which is engaged in this work of elucidation. It is the different ideas, opinions and views on this active faculty - otherwise called mind, intellect, reason, faculty of cognition - which divide the old and new Materialists as well as the Idealists into different camps. These parties all differ between them 
as to the mind and the way in which this mind arrives at science and how science must be constituted.

In natural science there is comparatively little difference of opinion on this subject, yet, as we have just heard from Hæckel, sufficient to arouse a lively discussion as to what is science and what is not. Classical, however, the controversy becomes only in the so-called "philosophical " branches of knowledge which deal with the doctrines and lives of the teachers of religion, of statesmen, politicians, jurists, sociologists, economists, etc., that is, with the most vital interests of human society. It is there that one is first to perceive to the full extent the import which attaches to what one thinks of the human mind and of the influence which a solid method of thinking, or, in fact, a theory of it has for human society.

No doubt, natural science knows how to use the human mind,-its successes are proof of that. But these same naturalists are also sometimes engaged in discussing politics, religion, socialism, etc., and though they know how to use their brains scientifically in their own province, this habitual use is not sufficient for purposes of solving successfully problems which arise in other domains. We, therefore, believe to have proved by this fact that we are justified in proceeding with our inquiry into the nature of the faculty of thinking and into the proper and successful mode of its application.

As we don't agree with the old materialists who thought that they had sufficiently explained the intellect by calling it the property of the brain, we cannot hope for a solution of the problem by subjecting the human mind to an anatomical dissection. Nor can the speculative way which expects to find out the nature of the mind by rummaging in the interior of the head, be ours 
because such idealist speculation has achieved altogether too little. Thus comes opportunely Haeckel with his opinion about the proper method of science. He contemplates the human mind, and how it worked historically, and this appears to us to be the right method.

Every natural product behaves with a peculiarity of its own; the stone remains stationary, and the wind travels from land to land. Nor is the mind a thing that can be got hold of at a certain place; true, we feel its activity in our head, but it does not remain there; it issues forth into the wide world and there it combines, if not chemically, still as a matter of fact with all objects of the universal Nature. As little as the wind can be separated from the air, can our mind be separated from the other natural objects; it only manifests itself as a phenomenon in mental combination with such natural things. Without the natural combination with other material the mind is not to be had. It is probably not a chemical element which can be produced in a pure state. And why should everything be chemical?

And so the mind knows something of plants and animals. Botany and Zoölogy are mental combinations. In natural sciences - generally speaking, in everything which we know positively - the human mind is naturally combined with the respective material things and is only to be conceived and represented in such combinations.

Now, Haeckel tells us of the melancholy host of zoologists of the Museum and botanists of the Herbarium and explains that the method in which they combined their mind with animals and plants was not the right one. And the succeeding scientists, too, who studied the more delicate and inner structures microscopically, but still confined themselves to mere description of the objects, did not know how to bring about the right combination 
between the subject and the object, mind and matter. It was only the discovery of the natural selection through the struggle for existence, given to the world by Darwin in 1859, which was a proper mental combination - so Haeckel thinks, and we take the liberty to differ.

Let not the reader misunderstand us. We do not dispute that Darwin and Haeckel have correctly and in a scientific way combined their individual minds with the vegetable and animal kingdom and produced clear crystals of knowledge. We merely want to call the attention to modern dialectical materialism which is of opinion that Darwin and Haeckel, however high their merits are, were not the first and not the only ones who produced such crystals. Even the melancholy zoologists of the Museum and the botanists of the Herbarium left us a good slice of science. The arrangement of the vegetable and animal kingdoms in classes, species and varieties according to different characters was a fully justified scientific combination of mind and matter, "bare description" though it was. Without thoughts it could not have been done. Certainly Darwin has done more; but still nothing but more. $\mathrm{He}$ added to the old a new light, but his light was by no means a different light from that of Linnæus. Darwin uses the "many accumulated biological facts" and adds some new ones; he describes Embryology and how by means of natural selection the changes are inherited and how these inherited changes by means of the struggle for existence become stronger, and so intermediate forms and new varieties arise. $\mathrm{By}$ means of observation and accumulation of facts and their description a new light is gained or, rather, the light gained previously is increased. The service rendered by Darwin is great, but not so overwhelming as to justify 
Leckel in making this "science" something higher than we everyday combination of the human mind with the objective facts.

We have already pointed out in our first article that the narrow materialism not only considers mind a property of the brain - a proposition which nobody disputes - but infers from that directly or indirectly that the faculty of reasoning or of knowledge predicated if the brain was not a substantive object of study, so that the study of the material brain yielded sufficient information of the mental property and force. As against this, our dialectic materialism proves that the qurstion ought to be considered after the precept of Spinoza from the standpoint of the Universe, sub specie aternitatis. In the endless Universe matter in the rense of the old and antiquated materialists, that is, of tangible matter, does not possess the slightest preferential right to be more substantial, i. e., more immersiate, more distinct and more certain than any other ?henomenon of Nature.

It is an essential brjadening of our sphere of knowledge to conceive the material subject, the brain, together with its mental predicate, that is, both the brain and the mind, as mere properties or phenomena or changes of the absolvte subject, the natural Nature which has no other nature besides, or above or outside. This conception restrains the extravagance with which materialists extoll their matter, and idealists their function of the brain to the skies.

Those materialists who make tangible matter the substance and the intangible function of the brain a mere incidence think too little of this function. In order to gain a more adequate and just idea of it, it is above all necessary to go back to the fact that they are children of one mother, that they are two natural phenomena on 
which we turn a light when we describe them and arrange them in classes, species and sub-species

When we declare as regards matter - and nobody will dispute it - that it is a phenomenon of Nature and state the same with regard to the mental faculty of man, then, of course, we still know very little of them. Yet so much we do know that they are twin-children, that nobody must separate them to any extravagant extent, that nobody must draw between them a distinction toto genere, toto coelo.

If we wish now, for instance, to know something more of matter, then we must do as the zoologists of the $\mathrm{Mu}$ seum and the botanists of the Herbarium did once upon a time,- we must try to ascertain, to study and to describe its different classes, families and varieties, how they rise, pass away and change into one another. This is the science of matter. Whoever wishes for more wishes something transcendental, and does not understand what knowledge means, does not understand either the organ of knowledge or its use. When the old materialists deal with special matters, they behave quite scientifically; but when they have to deal with abstract matter, with its general conception, then their helplessness in the science of knowledge stands revealed. It is precisely the merit of the idealists that they at least have advanced the use of abstractions and general ideas to an extent which enabled modern socialist materialism to recognize at last, that matter and conception are ordinary products of Nature and that there is not and cannot be anything which does not wholly belong to the one and only absolute category of the natural world.

Our materialism is distinguished by its special knowledge of the common nature of mind and matter. Wherever this modern materialism takes up the human 
mind as an object of study, it treats it like any other object of study, consequently like the zoologists of the Museum, the botanists of the Herbarium and the Darwinists treat the knowledge and description of their objects. Unquestionably, the former have by their classification thrown a light upon the thousands of their objects. Perhaps that light was not a very strong light and Darwin strengthened it in a way which made the additional light outshine the original one. Yet, the old "describers" had to "know" before they could classify, and Darwin's knowledge itself was nothing but a description guided by the conception of evolution and yielding, by a description of the natural proceedings, a more adequate picture of the accumulated facts.

With all that, the old zoologists and botanists were narrow-minded interpreters: they interpreted the varieties of the animal and vegetable kingdoms merely as regards their contiguity, and failed to see their evolutionary process. To have drawn within the limits of his observation the historical transformation constitutes in the main the merit of Darwin. It is impossible to deny the fact that it was Darwin's science which first illuminated the results gained by the zoologists of the Museum. Still, the same will also happen to modern natural science: future discoveries will enlarge those already made, will consequently make them always more and more valuable. Nothing and nobody can pose as the only true solution, but everything is to be considered from the standpoint of the Universe.

The materialist theory of knowledge amounts, then, to this statement, that the human organ of cognition radiates no metaphysical light, but is a piece of Nature which pictures other pieces of Nature whose essence is explained when we describe it and bring it in connec- 
tion with the whole Universe as the one Reality and the real Unity. Such a description demands from the epistemologist or philosopher that he should treat his subject in the same precise way as the animal world is treated by the zoologist. Should I be reproached with not following this precept immediately, I would point to Rome which, too, was not built in one day.

It is remarkable how those enlightened naturalists, who know so well that the eternal movement of Nature has through adaptation, selection, struggle for existence, etc., produced elephants and apes out of protoplasma and molluscs, should be reluctant to acknowledge that mind has developed in the same way. Why should not reason be able to accomplish what bone did? But true, bones did not do it, and reason cannot do it. It is the substantial force of the Universe, in which they participate, which has brought about the things that are, and all that the human mind can do is to form a picture of its gradual, consistent and rational working. Why does it wish for more? It only wishes for more because and in so far as it is too exacting and extravagant a taskmaster.

When we say not only of reason, but also of Nature in general that it is rational, we do not wish to convey the idea that this rational Nature and its working are the predetermined and purposeful work of a fantastic mind. Nature, which could develop the human reason, is such an astounding thing that it requires no central organ for its rational development. Wonderful Nature is not robbed of its wonderfulness by our "knowledge," " cog. nition," "interpretation"; it may, however, by a closer description or an adequate picture, well be freed from all transcendentalism, from all mystificaticn, - nay, interpreted and grasped, in so far as onc. does not form ar 
exaggerated idea of those mental functions, but gains a true conception thereof.

Just as the zoologist of the Museum got to know his animals by description of the class, species and family in which they have been arranged, so is also the human mind to be studied through finding the different varieties of the mind. Every person has an intellect of his own which together with those of all others must be considered as blossoms of the general mind. This general human mind has, like the individual one, its development partly behind, partly before it; it has had and will have to undergo different and manifold metamorphoses, and if we follow those back to the beginning of mankind we arrive at a stage where the divine spark manifests itself but dimly in bestiality. The bestialized human mind forms there the bridge to the animal mind proper, then to the mind of plants, to the spirits of the wood and mountains. In other words: in this manner we arrive at the understanding that between mind and matter as well as between all parts of the universal unity of Nature there are but gradual and hardly perceptible transition-stages, but no metaphysical differences.

It is because the old materialism did not understand this fact; because it was unable to conceive the ideas of matter and mind as but abstract pictures of concrete phenomena; because in spite of its religious free-thought, in spite of its disparagement of the divine mind, it did not know what to do with the natural mind and was on account of such ignorance unable to overcome metaphysics, - it is because of all that that Engels called this materialism metaphysical, and the materialism of SocialDemocracy, which has received a better schooling through the preceding German idealism, the dialectical.

In the eyes of this latter kind of materialism the mind 
is a collective name for the mental phenomen-, as matter is a collective name for the material phenomena, and the two together figure under the idea and name of the phenomena of Nature. This is a new epistemological mode of thinking which applies to all special sciences, to all special thoughts, and puts forward the principle that all things in the world are to be considered sub specie aternitatis, from the standpoint of the Universe. This eternal Universe is so combined with its temporal phenomena that all eternity is temporal, all temporality is eternal.

The substantiated mode of thinking of Social-Democracy throws thereby a new light upon the old problem with which idealism was afflicted, namely, how can we think truly, how is the subjective thought to be distinguished from the objective? The answer is: thou shalt not distinguish transcendentally; even the most exact representation, even the truest thought can only give you a picture of the universal varieties which exist within and outside you. It is not at all so difficult to distinguish realistic pictures from the fantastical, and every artist can do it with the utmost precision. The fantastica? ideas are borrowed from reality, and the most exact idea of reality are necessarily animated by a breath of fan. tasy. Exact representation and ideas render us excellent services precisely because they do not possess an ideal exactness, but only a moderate one.

Our thoughts cannot and must not agree with thei objects in an exaggerated, metaphysical sense of the word. What we desire and may and should desire, is to gain an approximate idea of reality. Hence, also reality can only approach our ideals. There can be, outside the idea, no mathematical point, no mathematical straight line. In reality all straight lines contain an admixture of crookedness, just as even the highest justice must still 
contain a grain of injustice. Truth is of a substantial nature and not of an ideal one; it is materialistic; it is not to be conceived through thoughts alone, but also through the eyes, ears and hands; it is not a product of thought, but on the contrary, the thought is a product of universal life. The living Universe is incarnate truth. 


\section{IV.}

DARWIN AND HEGEL.

It is well known that philosophers have often thrown out ideas far in advance of their time which subsequently found their verification in the exact sciences. Thus, for instance, Descartes is well known to physicists, Leibnitz to mathematicians, Kant to physical geographers. It may be generally said that philosophers enjoy the reputation of having influenced by their ingenious anticipations the progress of science. We wish to point out thereby that philosophy and natural science do not at all lie inordinately far apart. It is the same human mind which works in the one as in the other science by the same method. The method of natural science is more exact, but only gradually so, not substantially. There is in every sort of knowledge, even in natural science, a certain amount of obscure, mysterious "matter," a matter of cognition, alongside the luminous and palpable one and even the most ingenious anticipations of our philosophers are, in spite, or rather because of, their mysterious nature, still "natural." To have worked with success at a certain conciliation between the natural and the mental is the common merit of Darwin and Hegel.

We wish to render the now almost forgotten Hegel what is to due to him as the forerunner of Darwin. Mendelssohn, in a dispute with Lessing, called Spinoza a "dead dog." Just as dead appears now Hegel, who in his time, in the words of his biographer Haym, achieved 
in the world of letters a position analogous to that of Napoleon I. in the political. Spinoza has long since undergone resurrection from the state of a " dead dog," and so will Hegel, too, find his merits acknowledged by future generations. If he has lost his influence at the present time, it is merely a temporary eclipse

Hegel, it is known, once said that of his numerous disciples only one understood him and that one, too, misunderstood him. That such a general misunderstanding is more to be ascribed to the obscurity of the master than to the lack of understanding in the disciples, admits, of course, of no question. Hegel cannot be thoroughly understood because he did not understand himself thoroughly. With all that he is an ingenious anticipator of Darwin's theory of evolution, and with equal justice and truth one may say the reverse: Darwin is an ingenious interpreter of Hegel's theory of knowledge. The latter is a doctrine of evolution which embraces not only the origin of species of the entire animal world, but also the origin and development of all things. It is altogether a cosmical theory of evolution. We have as little right to blame Hegel for his obscurity as Darwin for not having exhausted all knowledge with regard to the origin of species.

Truly and surely who explains everything, explains nothing. From such fantastical desire the great philosopher was quite free, though his school was ready enough to worship him. Many Hegelians really believed in their time that the master could furnish them the absolute knowledge, and that it was only necessary to open one's mouth and swallow it. Still we also had such disciples who proceeded with earnest labors on the inherited soil and brought forth glorious fruit on the tree of knowledge. 
Let us be critical towards God and all men, Hegel and Darwin included. Darwin's theory of evolution has its indestructible merits. Who will deny it? Still a German, who has been brought up under the influence of his great philosophers, must not forget that the great Darwin was much smaller than his doctrine. How anxiously careful is he, not to draw the necessary conclusions! No one can overvalue the worth of exact research; but whoever does not perceive that it must be accompanied, if not by a flight into the Endless, at least by an endless flight, by a continuous soaring, does not understand the full value of exact experimental inquiry.

The theory of evolution which we will not say was solved, but was considerably stimulated and advanced by Hegel, received before all at the hands of Darwin an exceedingly valuable application or specification in relation to zoology. Still we must not lose sight of the fact that the specification was of no greater value than the gereralization in which Hegel excels; the one cannot and must not be without the other. The naturalist combines the two, and no philosopher who deserves the name will fail do so, either; it is only the more or the less which is characteristic for the two branches of knowledge. True, the necessity of specialization would sometimes be forgotten by the best philosophers; it may not even come to their consciousness in any clear form at all. But just as often would exact science forget the general aspect of its work, while it was not the worst investigators in the scientific domain who sometimes ventured on too bold a flight to the skies. The sporadic cloud-soaring of natural science and the exact anticipations of philosophers should prove to the reader that the General and the Special harmonize together.

All art is natural art,- despite the usual opinion which 
places Nature and Art at an over great distance from each other; and likewise all science, philosophy included, is science of Nature. Speculative philosophy, too, has its exact object, namely, "the problem of cognition." It would, however, be rendering the philosophers too much credit if we were to say that they have solved their problem. Other branches of knowledge, especially those of natural science, have cooperated; for science of all branches, of all nations and of all the times is the general result of a closely connected coopperation. The philosophers have assisted the naturalists, natural science has helped philosophy until the problem of knowledge is now developed, revealed and clearly worked out.

There is no question as to what ought to be the name of the subject-matter which is studied by the physician or astronomer, whilst the subject-matter of philosophy was at first much disputed so that one might say that the philosophers did not know what they wanted. Now at last, after thousands of years of incessant philosophic development, it came to be recognized that the "Problem of Cognition" or "Theory of Science" has been the object and the result of philosophic work.

In order to understand clearly the relation between Hegel and Darwin we are bound to touch upon the deepest and most obscure questions of science. The subjectmatter of philosophy is just one of those. Darwin's subject-matter is undoubted. He knew his object; yet it is to be observed that Darwin who knew his object wanted to investigate it,- consequently did not know it through and through. Darwin investigated his object, " the Origin of Species," but he did not exhaust it. This means that the subject-matter of every science is endless. Whether one wants to measure the Infinite or merely the smallest atom, one always has to deal with the Im- 
measurable. Nature, both as a whole and in its parts, is inexhaustible, not knowable to its last particle,-consequently without beginning and end.

The recognition of this every-day Infinitude is the result of science, although the latter started from a transcendental religious or metaphysical Infinitude.

Darwin's subject-matter is just as endless and unknowable to the very last particle as Hegel's. The one inquired into the origin of species, the other into the process of human thinking. The result in both cases was the doctrine of evolution.

We have to deal here with two very great men and with a very great thing. We try to show that these men did not work in opposition to each other, but in the same direction, on the same line. They have raised the monistic conception of the world to a height and strengthened it with positive discoveries that up till then were unknown.

Darwin's doctrine of evolution is confined to the animal species, and removes the rigid lines which the religious conception of the world sets up between the classes and species of living creatures. Darwin emancipates science from the religious class conception and ejects divine creation from science in respect to this special point. In this point he puts in the place of the transcendental creation the matter-of-fact self-development. To prove that Darwin did not fall from the clouds it is but necessary to remember Lamarck who disputes with Darwin the honor of priority. This, however does not diminish the service rendered to science by Darwin; whilst Lamarck can lay claim to the philosophical anticipation, Darwin can claim the specified proofs.

To our Hegel belongs the honor of having placed the self-development of Nature on the broadest basis, of 
having emancipated knowledge from the class-view in the most general way. Darwin criticises the traditional class-view zoologicaliy, and Hegel universally.

Science makes its way out of the darkness to light. Philosopliy, tco, which aims at the illumination of the process of human thinking, made its way upwards; that it pursued its object rather instinctively than otherwise became by the time of Hegel tolerably patent to it.

The main works of philosophy move about the "method," the critical use of reason, the doctrine of science or of truth, the way and manner in which man thinks, in which he should use his head. It was the aim of philosophy to inform itself of the special piece of the universe which serves as an instrument of the illumination of the universe.

We draw special attention to the dualism, to the double problem in this endeavor: the Universe was to be illuminated and at the same time the lamp, by means of which it was to be illuminated. It is preeminently this double problem which confuses the work of philosophy. Science starts from the desire of illumination and does not know at first what to take hold of, whether the Cosmos as a whole, or gradually and piecemeal. Many a time it had already entered the practical road without having arrived at any guiding principle. In the time of Hegel the problem was as yet to a large extent obscure, still the way had been considerably cleared. It was Kant who desisted from the direct search after the whole wisdom of the world and took up, at first, specially the piece of the Universe called thinking. This piece, according to tradition, belonged preëminently to the metaphysical class of the transcendental things. Kant by his critique has done enough to emancipate the intellect from this sinister class-character. Had he succeeded in this completely, 
had he proved to us entirely that Reason is a thing which together with other things belongs to the same natural series, he would have, like Darwin, delivered a crushing blow against the transcendental way of classification as well as against Religion. No doubt, Kant has done so, but he did not cleanly cut off the ear of Malchus and left therefore still some work to his successors.

Hegel was an excellent successor to Kant. When we place those two side by side, the one illustrates the other, and the two illustrate Darwin. Kant chose Reason as his special object of study. In dealing with it he could not help drawing other things within his circle of research. He studies Reason as it behaves in the active pursuit of other sciences; he studies it in its relation to the rest of the world and tells us a hundred times that it is limited to experience, to one indivisible world which is temporal and at the same time eternal. Hence it ought to be clear to the reader that in the teaching of Kant general knowledge of the world and special critique of Reason are united.

It is clear at a glance that Kant's discovery of the limitation of human Reason by experience was both philosophic science and scientific philosophy. The same holds good of Darwin's doctrine of the "Origin of Species." $\mathrm{He}$ proves on that point scientifically that the world develops in itself and not from the heavens above - "transcendentally" as the philosophers say. Darwin is a philosopher, though he makes no claim to that. To have worked for the monistic conception, both by his special demonstrations and general conclusion, he has in common with Kant and Hegel.

Hegel teaches the theory of evolution; he teaches that the world was not made, is not a creation, has not an invariable and fixed existence, but is always in the mak- 
ing by its inherent force. Just as with Darwin the classes of animals are not divided by unbridgeable gulfs from each other, but on the contrary, are linked with each other, so with Hegel all categories and forms of the world, nothing and something, being and becoming, quantity and quality, consciousness and unconsciousness, progress and inertia - all inavoidably flow into each other. He teaches that there are differences everywhere, but nowhere - " exaggerated," metaphysical, transcendental differences. According to Hegel there are no such things which differ from each other "essentially." The difference between essential and non-essential is only to be understood as relative and gradual. There is only one absolute thing, and that is Cosmos, and everything which hangs about it are fluid, transient, changeable forms, accidentals or properties of the general being which in Hegel's terminology bears the name of the Absolute.

Nobody will think of asserting that the philosopher has accomplished his work in the most lucid and complete manner. His teaching made further development as little superfluous as that of Darwin, but it gave an impetus to the entire science and the entire human life,an impetus of the highest importance. Hegel has anticipated Darwin, but Darwin unfortunately did not know Hegel. This "unfortunately" is not a reproach to the great naturalist, but merely a suggestion to us that we should supplement the work of the specialist Darwin by the work of the great generalizer Hegel and proceed still further to greater crearness.

We have stated that Hegel's philosophy was so obscure that the master could say of his best disciple that he misunderstood him. It was with the view to illuminating this cbscurity that not only the succeeding philosopher 
Feuerbach and other Hegelians have worked, but also the entire scientific, political and economic development of the world. When we consider Darwin's discoveries, and the latest theory of the transformation of energy, it must at last become clear to us - what occupied the best minds during three thousand years of civilized life that the world is not made up of fixed classes, but is a fluid unity, the Absolute incarnate, which develops eternally and is only classified by the human mind for purposes of forming intelligent conceptions.

* $\quad * \quad * \quad * \quad * \quad * \quad * \quad * \quad * \quad *$

Ernst Haeckel, the well-known naturalist and disciple of Darwin, says in his preface to a paper read by him at Eisenach on September 18, 1882, and published afterwards at Jena, "that the present attitude of Virchow towards Darwinism is entirely different from that which he assumed at Munich five years previously. In rising at the above mentioned Congress of Anthropologists immediately after Dr. Lucæ he (Virchow) not only turned against this latter's assertions and paid Darwin the merited amount of his high admiration, but he expressly acknowledged that his more important propositions are logical postulates, irresistible demands of our reason. 'Yes,' said Virchow, 'I do not for a moment deny that the generatio aquivoca is a sort of general demand of the human mind. . . . Also the idea that man has evolved through a slow and gradual development from the ranks of lower animals, is a logical postulate." "

The enlightened knowledge of Nature, proceeds then Haeckel in his speech, " recognizes only that natural revelation which is open to everyone in the book of Nature and can be learned by every one who is free from pre. conceived notions and is endowed with healthy senses 
and a healthy mind. From the study of that book we gain that monistic and purest form of belief which amounts to a conviction in the unity of God and Nature and which found long since its complete expression in the pantheistic professions of our greatest poets and thinkers."

That our greatest poets and thinkers exhibit the tendency to a monistic and pure form of belief and strive after a physical view of Nature which makes all metaphysics impossible and excludes from the scientific world the supernatural God together with the miracle-rubbish,- that is quite true. But when Haeckel gets carried away by his feelings so as to declare that the tendency "has long since found its most complete expression," then he is laboring under a very grave delusion,- - a delusion as regards even himself and his own profession of faith. Haeckel, too, does not know yet how to think monistically.

We shall presently justify our reproach; but it may be stated at once that it affects not only Haeckel, but the entire school of our modern natural science, because it has neglected the results of two and a half thousand years of philosophic research, which has back of it a long empirical history not less so than experimental science itself.

The above mentioned lecture by Haeckel contains the following passage: "We should like to emphasize especially the conciliating and soothing effect of our genetic view of Nature,- this the more so as our opponents are continually engaged in trying to ascribe to it destructive and dissolving tendencies. The latter are supposed to work not only against science, but against religion also and in so far against the most important foundation of our civilized life in general. Such serious charges, in $\omega$ far as they really are based on conviction and not 
merely on sophistical syllogisms can only be explained by a lamentable lack of knowledge of what constitutes the real essence of true religion. This essence is not based on a special form of faith, of domination, but rather on the critically sound conviction of the ultimate unknowable and common cause of all things. In this acknowledgment that the ultimate cause of all phenomena is with the present organization of our brain unknowable, critical natural philosophy meets with dogmatic religion."

There are three points in this confession of Haeckel which should be kept separately and prove to us that the "monistic view of the world" has even in its most radical and scientific representative not found as yet its complete expression.

I. Haeckel wants to clear natural science from the reproach of having "destructive tendencies." This enlightened science, which knows only of a natural revelation and has its religion or form of faith in the unity of God and Nature should -

2. Not act destructively upon the prevailing religion which is based on a supernatural or unnatural revelation. This unnatural religion, forsooth, possesses a true essence which is also recognized by the natural or scientific religion. This is the common cause of all things.

Very well, the old belief has the common cause of all that is in a personal God who is supernaturally, indescribably, inconceivably a spirit or a mystery. The new religion $\dot{a}$ la Haeckel believes to possess in Nature also named God - a common cause of all things, and so the two forms of faith possess a common cause. The difference only is that the cause, recognised by natural science, is the every-day Nature which, of course, is mysterious enough, yet its mysteries, its riddles are only 
such as natural science is engaged in solving. The sort of Nature which Haeckel transforms into a God, which he deifies, is also a mystery, but only a natural, an everyday mystery, whilst the supernaturally revealed God is, according to all that is said of him, of a nature thoroughly inexpressible, undefinable by any words at our command. Or, since one cannot help treating the good religious God with human words, it is easy to understand how in such process all these names and words lose their human sense. Just put the religious God and the natural God of Haeckel side by side: both of them are omnipotent; Nature makes everything which is made, but only in a natural, every-day sense. The good God in Heavens, too, makes everything, but not naturally; he makes it unnaturally in a sense and in a way which does not even admit of being defined, of being expressed. The good God, forsooth, is a spirit, but not such as dwells in old castles, nor such a limited one as man has in his head, but a spirit like no spirit, a monster-spirit, a monster-mind whose constitution cannot even be expressed in words.

Before we pass to the third point of the "purest form of faith," we must consider a little closer the two already mentioned. It will then be the more easy to dispose of the third and last one as well as of the final combination of all the three in one.

The difference between the every-day natural and the unnatural, between the physical and metaphysical revelation, religion or divinity, is so great that the enlightened view of Nature, as represented by Haeckel the Darwinian, would have been justified to forego the old names and the revealed divine religion and put "destructively" against it the monistic view of the world. By not doing that, Darwinism only manifests the limi- 
tation of its theory of evrlution. In so far as it want; to remain monistic it ought to have viewed Nature only physically, not metaphysically. It must see in Nature the primary cause of all things, but not a mysterious one, that is, a not yet explored, but never an inexplorable cause,- inexplorab'e in the metaphysical sense.

That Haeckel, however, the most radical representative of natural science monism, still rides that dualistic horse, is proclaimed openly by the third point which finds the ultimate cause of all phenomena "with the present organization of our brain" unknowable.

What is knowable?

The whole context to which that word belongs shows conclusively that our monistic scientist is still in the mire of metaphysics. Nothing in the world, not an atom of it, is to be known out and out. Everything in the world is inexhaustible in its secrets, no less than it is imperishable and indestructible in its essence. With all that, we learn every day more and more to know the things, and learn that there is nothing which is closed to our mind. Just as the human mind is unlimited in the discovery of mysteries and problems, so, on the other hand, the inexhaustible and the unknowable yield themselves readily and unreservedly to its inquiries and its attempts to solve them.

It is due to the "old belief " that the words, the speech, nave acquired a double meaning, - a natural, relative and common-sense one, and a transcendental, metaphysical one. The reader may notice the double effect of natural science when it is compromised by metaphysics; it contains mysteries and propagates, by their solution, the conviction that what was formerly a mystery becomes through research an ordinary, everyday thing in the chain of interrelation. Nature is full of mysteries which re- 
veal themselves to the inquiring mind as ordinary properties. Nature is inexhaustible in scientific problems. We sound them and we can never come to an end with this sounding. 'The human common-sense is quite right when it finds the world or Nature unfathomable, but it is also right when it repudiates all metaphysical unfathomableness of the world as transcendental folly and superstition. We shall never finish with our exploration of Nature, and yet the more natural science proceeds in its exploration the more strikingly patent it becomes that it need not at all fear the inexhaustible mysteries, that "there is nothing which resists it" (Hegel). Hence it follow's that the in:xhaustible "primary cause of all things" is being pumped daily with our instrument of knowlefge which is no less universal or infinite in its capacity for exploration than Nature in setting problems.

"With the present organisation of our brain!" No doubt. Our brain will yet, through sexual selection and struggle for existince, develop enormously and probe more and more the natural cause of things. If that phrase is meant in this sense, then we perfectly agree. But it is not mesnt so by the metaphysically prejudiced Darwinian. The human mind is supposed to be too small for the thorough exploration of the world, in order that we may believe in a monster-mind and not combat him "destructively."

Darwin with all his merits was an exceedingly modest man; he was content with a special branch of inquiry. Everybody should be as modest, but not everybody should limit himself to the same specialty. Science has not only to investigate the morphology of plants and animals; it has to deal also with the problem, as to how the unknowable changes into the knowable, and must not exclude from is 3 province the ultimate cause of all existence. 
Hegel has propounded the doctrine of eviution on a far more universal scale than Darwin. We do not wish on that account to prefer or to subordinate the one to the other, but merely to supplement the one by the other. If Darwin teaches us that amphibia and birds are not eternally separated classes, but emerge from one anothe? and merge into one another, then Hegel teaches us that all classes, that the whole world, is a living being which has nowhere rigid limits so that even the knowable and unknowable, the physical and metaphysical, flow into one another, and the absolutely Inconceivable is a thing which belongs not to the monistic, but to the dualistic, religious view of the world.

"We have to go back twenty-five centuries, to the dawn of classical antiquity in order to find the first germs of a natural philosophy, that pursued with a clear purpose Darwin's object, viz., to find the natural causes of the phenomena of Nature and thus to dissipate the belief in supernatural causes, in miracles. It was the founders of Greek philosophy in the seventh and sixth centuries B.C. who laid this true cornerstone of knowledge and tried to discover a natural common catuse of all things " (Haeckel, 1. c.).

Now, if our esteemed naturalist drops this "natural" cause and substitutes a mysterious cause which is so wonderful that we cannot possibly know anything of it, he again leaves us a metaphysical ultimate cause to believe in, which brings us in line with religion.-Does he not thereby play false to the common aim of Darwin and his critical natural philosophy?

According to our monism Nature is the ultimate cause of all things; it is also the cause of our faculty of cognition; yet this faculty, according to Haeckel, is too small to know the ultimate cause! How does that fit in? 
Nature is recognised as the ultimate cause, and yet it is to remain unknowable!

The fear of destructive tendencies has taken hold of even such a determined evolutionist as Haeckel. He abandons his own theory and lands in the belief that the human mind must content itself with the phenomenon of Nature and is unable to reach the true essence of it. The ultimate cause is, according to our naturalist, an object which does not come within the province of natural science.

"The contentedness in receiving and the parsimony in giving are not virtues in the domain of science," says Hegel in the preface to his "Phenomenology of the Mind." He goes on saying: Those who merely seek edification, who desire to envelop in a mist the earthly manifold richness of existence and of thought, and hanker after the vague enjoyment of this indefinite divinity, may look out where to find it; they will easily discover the means to rave about it and to put on mysterious airs. But philosophy must take care not to wish to become edifying.

Darwin's aim has been represented by his most acknowledged disciple as a philosophic one,- to find out the natural causes and to dispel the belief in supernatural intervention and miracles. And yet the wonderful inconceivableness of the common cause of all things, the wonderful limitation of the human mind must still remain untoucher for the sake of edifying conciliation!

Our reproarh against Haeckel, the Darwinian, amounts to this: he has not assimilated the results of two and a half thousand years of philosophic evolution and therefore, though he may, perhaps, know very well the nature of " the present organisation of our brain," he nevertheless sadly lacks the knowledge of the process of cognition 
which is a thing different from the physiology of the brain. At least, so much do the above quoted passages show that Haeckel's ideas of the natural and unnatural, of the wonderful and knowable, as well as his ideas of the natural divinity and the divine nature are not monistic, but are still permeated by a very reactionary dualism.

As to the pantheistic professions of our greatest poets and thinkers,- professions which culminate in the conviction of the unity of God and Nature, Hegel has left us a very characteristic doctrine. According to it, we not only know the unity of things, but also their difference. A poodle and a bloodhound are both dogs, but this unity does not prevent differences. Nature has much likeness to God,-it rules from eternity to eternity. As our mind is its instrument, a natural instrument, Nature knows everything that there is to be known. It is omniscient. Yet natural wisdom is sufficiently different from divine wisdom that there are enough scientific reasons for the destructive tendencies to do away entirely with God, religion and metaphysics, - to do away in a rational manner so far as they can be done away with. The confused ideas have been before and will therefore remain as have-beens in all eternity.

The Hegelian, too, assumes towards religion an attitude which is merely scientific, not irreconcilable. We readily recognize religion as a natural phenomenon which in its time and under special circumstances was fully justified, and, like all phenomena, like wood and stone, carries within its transient shell an eternal germ of truth. What Hegel has failed to do, or done imperfectly, was supplemented by his follower Feuerbach. He brought that germ to light and showed that burned wood does not come to nothing, but turns into ashes and undergoes in that process such a change that the use of the former 
name is no longer permissible. The transformation of wood into ashes is a development; likewise religion develops into science. And when the Darwinian, in spite of that manifests a desire to leave in the ultimate cause of all things something undeveloped and undevelopable, something mysterious and metaphysical he only shows that he has not grasped the doctrine of evolution in its universality and that the great Hegel who developed the doctrine of cognition is for him a "dead dog."

Let us cast a cursory glance over Darwin's work. His subject matter is the animal in general, the amimality, the animal life in its generic sense. Before Darwin we only knew living individuals, and the general animal was a mere abstraction. Since then, however, we have learned that not only individuals, but also the general animal, is a living being. The animality exists, moves and changes, undergoes a historic development, is a widely ramified organism. Before Darwin the ramifications or divisions of the animal world were marked off by zoologists according to a fixed system. They divided it into classes,fishes, amphibia, insects, birds, and so forth. Darwin has introduced life into this system. He showed us that animality is not a dead abstract entity, but is a moving process of which our knowledge has up till now given us but a scanty picture. And if the old knowledge of the animal world was a scanty picture and the new one is more substantial, more complete and truthful, then the gain from it by our knowledge is not confined to the animal world. We also gain at the same time an insight into our faculty of cognition, viz., that the latter is not a supernatural source of truth, but a mirror-like instrument which reflects the things of the world, or Nature. 
Darwin was the negation of a metaphysician. Without, perhaps, knowing it or wishing it, he took metaphysics, the belief in the miraculous, by the throat; he removed in zoology the unnatural class-lines and gave the edifying belief in the metaphysical, wonderful nature of the human organ of cognition a blow which stuck, and substantially illuminated philosophy, the critique of reason or theory of cognition.

If not Darwin himself, at least, his follower Haeckel told us that his master was a glorious fighter against metaphysics. This is the ground on which he meets Hegel and all philosophers as allies. All of them strove after illumination,- especially the illumination of the metaphysical dimness, though they themselves were laboring more or less under it.

Hegel has much in common with the old Heraclitus, nicknamed "the Obscure." Both of them taught, that the things of the world do not stand still, but flow, that is, develop, and both of them deserve being nicknamed " the Obscure." To illuminate a little Hegel's obscurity it is necessary to pass in brief review the development of philosophy.

Science began its career more as philosophy than natural science, that is, it lived at the beginning more in metaphysical speculation than in real Nature. True, mankind had already made some excursions into natural science before, just as our most modern naturalists sometimes land in a backward philosophy; still we must say in all truth that the old cultivators of science were philosophers while the modern were naturalists. Now at last the conciliation is near at hand, or even already concluded. Now the question is of a completely systematic, natural view of the world which has neither before nor behind it anything supernatural, "edifying" or meta- 
physical. Since the days of the Greek colonies, since Thales, Democritus and Heraclitus, Pythagoras, Socrates and Plato, philosophy sought to solve the riddle of $\mathrm{Na}$ ture. But they were continually in doubt and in the darkness as to the ways and means of inquiry, whether the solution of the problem was to be sought in the outer or inner world, in matter or in mind. And in modern times, too, when after a thousand years of darkness a new scientific day dawned, and the philosophers took up again the work of the old predecessors, - at the time of Bacon, Descartes and Leibnitz - the dispute about the "method" and the proper "organon" for the acquirement of truth was still going on. The whole thing appeared doubtful,- especially the nature of truth which was to be investigated and the riddle which was to be solved, whether it be natural or supernatural,-indeed, so doubtful that, as is well known, Descartes made Doubt the primary condition and the cardinal sirtue of inquiry.

Yet science could not stop at that point. It had to arrive at Certainty,- particularly on that question which for Descartes and for all other philosophers was the most pressing. It needed certainty about the method, that is, how one must proceed in the inquiry in order to arrive at scientific truth which is identical with certainty. At the same time natural science already began to apply practically the method which the philosophers were still searching for. And the great Descartes was, too, partly a scientist, and proceeded in philosophy so far as to make the above mentioned method the definite, clearly-conceived subject of his main work.

And now the light spreads more and more. The metaphysical, the incoriceivable, the mysterious has to go, and must be driven out of science, and its place taken up by 
certainty, by the undoubted. The process is in full swing. The philosophers develop mightily and the scientists render them mighty assistance.

And here comes the great Kant with his question: "How is metaphysics possible as a science?"

Let us keep in mind what the old Königsberg philosopher means by "metaphysics." He means by it the miraculous, the mysterious, the inconceivable, that is the traditional, theological subject-matters: "God, Freedom, Immortality."

You have been talking about it a pretty long time, says Kant. I will now try and see whether it is really possible to know anything about the matter. And he takes as his model Copernicus. After astronomy had for a long time allowed the sun to move round the earth and not much came out of it, Copernicus turned the method upside down and attempted to see whether it would not be better when the sun was fixed and the earth moved round. With the assistance of the faculty of cognition Man has, up to the time of Kant, tried to probe the great metaphysical, the existence of the world-miracle. The famous author of the "Critique of Pure Reason" turns the thing round and takes the piece of Nature which man feels glowing in his head,- the lamp of illumination of which some empirical information had been gained before - and attempts to find out, whether with this lamp it is possible to illuminate the great sea-serpent which since the Christian era has been known under the name of God, Freedom and Immortality, but in classical antiquity was designated by its wise men as the True, the Good and the Beautiful.

This classical name is very apt to mislead us. True, good and beautiful specialties, as they are daily cultivated by the exact sciences, must clearly be distinguished from 
the great sea-serpent which floated before the eyes of the ancients when they investigated the abstract ideas. The Christian name with which Kant designates the metaphysical monster is in the present stage of the problem better calculated to bring out the difference between physics and metaphysics, between the perceptible Nature and the senseless Beyond.

On the other hand, we are also apk to miss the true importance of the sea-serpent, if we concentrate our attention exclusively on its religious culor. Its belly is yellow and glitters with God, Freedom and Immortality; but its back takes the color of its environment and by this mimicry it is able, like the white hare in the snow, to escape our eye. When, however, we come nearer and inspect the thing closely, we find on its grey back the words "The True, the Guud, the Beautiful " imprinted in Greek letters of a dark hise. If we resume in one word the inscriptions which the philosophical-theologicalmetaphysical sea-serpent bears on its back, the beast will, perhaps, be most aptly characterized by the beautiful name, "Truth." The double meaning of this word ought not to be missed. The sea-serpent-truth is transcendental. Still it rests on a natural basis, on the basis of natural truth, which, of course, must be distinguished from the transcendental one. The natural truth is the scientific truth; it is not to be gazed at either with enthusiasm of with "edification," but it must be contemplated soberly, and it is so general that all things, even the paving stones, belong to it. The sea-serpent-truth is a human delusion of the childish prehistoric times; the sober truth is a collective name which embraces in one conception both true fancies and true paving stones.

Kant asked: How is metaphysics, that is, the belief in the oupernatural, possible as a science? And he replied. 
This belief is not scientific. After having examined the intellect in its various faculties Kant comes to the conclusion that the human mind can only form images of the phenomena of Nature and as far as science goes, does not know and does not wish to know of any other "true" spirit. Though the time for such a radical pronouncement was not ripe yet, nevertheless it is well known that Kant concludes his inquiry with the statement that Reason - meaning thereby the highest measure of our intellectual efforts - can only understand the mere appearances of things.

The inquiry into the nature of the sea-serpent has in the hands of the philosopher Kant changed into the scientific and sober question, what sort of a light is it and what is it to illuminate. Still Kant, too, was unable to extricate himself from the muddle, whether he should combat the metaphysical monster, or criticize Reason, or do the two things at the same time. His successors, Fichte, Schelling and Hegel, had to take up the same work and continue it. By the inquiry into the human mind the head of the sea-serpent is to be crushed,- that is certain, so much had the road been cleared by the Königsberg Copernicus. Still we must not allow ourselves to be carried away by the enthusiasm for his heroic deed to such an extent as to ignore the fact that neither he nor his followers have completely purged their emotions from the wretched metaphysics, from the belief in a higher truth than the natural one. They rather guess at the monstrous than perceive it, and they onlv gain their victory step by step.

Kant argues as follows: Even if our Reason be limited to the knowledge of natural appearances, even if we could not know anything beyond that, we still must believe in something mysterious, higher, meta- 
physical. There must be something behind the appearances, "since where there are appearances there must be something which appears." So concludes Kant,only seemingly a correct conclusion. Is it not enough that natural appearances appear? Why should there be anything else behind them,- - something transcendental, inconceivable - but their own nature? However, let that pass. Kant expelled - at least formally - metaphysics from scientific pursuits and relegated it to the province of belief.

That was in the eyes of the successors and especially of Hegel too little. The belief which Kant had left, of the limited mind, the limits which he had set to scientific inquiry, were to this giant of thought too narrow; he soared into the Universe and there "there should be nothing to resist him." He wants to escape from the metaphysical prison into the fresh physical air; and this is not to be understood in the sense as if Hegel himself were mentally free and wanted to assist others to gain such freedom. No, the philosopher himself is prejudiced and wants to be instructed. His mind, his flame is but a portion of the universal light which glows in every man, which wants to, and can illuminate everything, but can only proceed step by step.

In consequence of the more or less entangled nature of things our discussion, too, cannot be free from entanglement. We wish to elucidate the connection between the old philosophers and their " last knight," then between Hegel, Darwin and the whole science. Hence our episodical excursions in various directions.

In order to elucidate the teaching of Hegel in relation to that of Darwin it is necessary above all to keep in mind the bewildering double nature of all science. Every scientist - and Darwin, too - illuminates not only 
his special subject-matter on which he is consciously engaged; but his special contributions at the same time inevitably assist in illuminating the relation of human mind to the world as a whole. This relation originally was a slavish, religious, non-human one. The human mind considered itself and the world as a riddle which it was unable to illuminate with the light of his knowledge, but which could only form fantastical imaginings of the overpowering metaphysical thing. Every contribution which has been made to science since the beginning of human history has weakened the slave chain in which our race was born. Both the philosophers and the scientists were fettered by it, and the emancipating work was done conjointly and has proceeded vigorously to this very day. The scientists, however, have no reason to look down upon their colleagues, the philosophers. They, the scientists, with Darwin at their head, look straight in the face of their selected special subject-matter, and squint at the same time at the general riddle, the riddle of the Universe. Even when Darwin declares explicitly that science has nothing to do with the sea-serpent and thus clears it out of his way or relegates it $\dot{a}$ la Kant to the province of belief, these are merely subjective limitations or anxieties which may be pardonable as far as the individual is concerned, but must not fetter the universal research of the human race. Now, there cannot be knowledge here and belief there; it is the solution of all doubt that is required, and whosoever's doctrine is opposed to such a demand will be rejected by posterity as a piece of cowardice.

It was said before that the scientists boldly contemplate their specialties while they squint at the monstrous miracle-world. We may now add that the philosophers iet the rays of their intellectual light fall direct upon the 
great sea-serpent and get thereby so dizzy that they squint back at their own light as something metaphysical. The confusion which arises from the bewildering double nature of knowledge is now overcome by the discovery that the human mind, or the light which illuminates the things, is of the same nature, of the same kind as the objects which are illuminated and that is the result of ages of philosophic thinking.

Kant left to posterity the excessively humble opinion that the light of cognition of his race is far too small to illuminate the great, wonderful beast. By showing that it is not too small, that our light is neither smaller nor larger, neither more wonderful nor less, than the object which has to be illuminated, the belief in miracles, in the sea-serpent, i. e., metaphysics, is at once done away with. Simultaneously man loses his excessive humbleness; and it was our Hegel who substantially contributed to that result.

A thorough perception of the situation requires the historical reconstruction of philosophic development, piece by piece in all the details. Still, we may in this respect, too, content ourselves with a brief sketch, since general education is now so widely spread, that the interested reader can easily supply himself the fitting illustrations to the picture presented here.

The labors of Darwin and Hegel, however differing in other respects, have this much in common that both of them combat the metaphysical, the non-perceptible and the nonsensical. While proposing to explain both the difference and community of the two thinkers we cannot help drawing within the province of our investigation the great sea-serpent. The sport, however, is rendered difficult by the numerous names which in the course of History have become attached to the monster. What 
is metaphysics? According to the name it is a branch of study,- or rather, it was, and now it casts its shadow on the present. What is it after? What does it want? Of course, enlightenment! But on what subject? On the subject of God, Freedom and Immortality. This sounds nowadays quite parson-like. And even if we should characterize its subject-matter by the classical names of the True, the Good and the Beautiful, there is still enough occasion left to make it clear, both to ourselves and to the reader, what it is for which the metaphysicians are looking? Without this it is impossible to measure and to explain what Darwin or Hegel accomplished or left undone and what, in consequence, there is still left for posterity to accomplish.

The sea-serpent cannot be at all characterized by an apt name since it has so many. Its origin goes back to the childhood of the human race, and the comparative philology is agreed upon the point that in those prehistoric times the things had many names and the names denoted many things, and this resulted in a great confusion which in modern times has been investigated and recognised as the source of mythology.

One has only to see what, for instance, Max Müller has to say on that point in his "Chips from a German Workshop." We are told there that the heathen and Christian fables about God, etc., were no empty nonsense; but natural developments of the store of speech. It was the poetical predilections of the ancient peoples that found vent in the language. Sober as we have become by now we still use such expressions as that of "killing time." Such pictures, full of sense and intelligence, served the ancients, inclined as they were to poetry and transcendentalism, for the filling out of the metaphysical wonder-world. Names are and have al 
ways been images of things. Those who forget this simple fact and ascribe to words a transcendental sense, are engaged in metaphysics. The latter is the general idea underlying all fables. The poet is a conscious fablespinner, fables are unconscious poetry. Hence it follows that when we speak of the wonder-world it all depends on the consciousness with which we accompany our words. Everything which exists is heavenly, divine, indescribable, inconceivable if we only mean to give thereby vent to our overpowering emotions caused by the natural wonderfulness of Nature. But nobody may in a sober manner express himself to the effect that everything which exists is a sea-serpent and is bound up with the unnatural truth or with something which the metaphysical enthusiast calls God, Freedom and Immortality.

It was not to overcome poetry, but to overcome the unconscious, exaggerated poetry that constituted the object of the movement for human enlightenment in which all workers of science have participated, partly deliberately, partly against their will. 


\section{V.}

\section{THE LIGHT OF COGNITION.}

Where is light to be got from? Moses brought it down from Mount Sinai; but after his people had been praying for more than three thousand years: Thou shalt not steal, they steal like ravens to this very day. That means that the Revelation proved futile. Then came the philosophers and wanted to extract light from the innermost of their heads, a priori knowledge as they call it. But what had been established by one to-day was upset by the other the next day. Natural science chose a third path, the inductive path, and drew its wisdom from observation. This discipline has finally obtained true, real, durable knowledge which is accepted by everybody and is not disputed - and cannot be disputed by anybody. Hence it clearly and unmistakably follows that we must seek enlightment along the road entered upon by natural science.

Still there are a good number of people - even among the "higher" circles and equipped with the best of knowledge, who declare themselves not satisfied with this light. They speak of the metaphysical craving, they build up a literature of their own and try incessantly to prove that all interpretation and knowledge of natural science, however fertile in individual branches, is, on the whole, inadequate. "The nature of matter," they say, "is in the last resort inconceivable; all mechanical interpretation of Nature refers only to changes of the enigmatic sub- 
stance and leaves our craving for causation in the last instance unsatisfied."

Julius Frauenstädt says: "The need for metaphysics has been compared by Schopenhauer to the need of a man for further information when finding himself in a totally unknown company whose members are introducing themselves to him one after another as friends and uncles. Where the deuce do I come to such a company of friends? This is the specifically philosophical question. Where natural science ends, there philosophy begins." . . . "Though the subject of both is the same," says Frauenstädt further, "the whole world, the Cosmos,- nevertheless natural science studies its subject from the point of view of its law-determined manifestation, whilst philosophy studies it in its inner essence." Only, thus, we must at once add, such philosophical contemplation has not borne any fruit and has not discovered anything of the inner essence of Nature.

Nature, as is known, gives us only phenomena, transformations. Everything flows, everything is in the making, in emerging and submerging. The philosophers, however, want something substantial, essential, what Dühring calls "unchangeable truths." As nothing of this kind can be found, the majority have desisted from further searching and turned, after the example of Kant, from philosophy to "critical philosophy," that is, they shift the blame for not finding the substantial, unchangeable spectre, on to the wretchedness of our faculty of cognition which, being incapable of anything higher, creeps about the treasures which rust and moths destroy.

And thus, as thousands of years ago, we hang between heaven and earth. Many have succeeded in extricating themselves from that position; but only in practice. Since religion and metaphysics could not yield 
anything positive, the materialists of the old school content themselves with jumping over the supernatural snares and tricks and passing over to the scientific order of the day. Stiebeling says: "A bridge can only be built from that bank where natural science has pitched its camp. It will be a pontoon-bridge. All new facts, observations and discoveries will be joined one with the other in a regular order till they reach the other bank lying in the misty distance. It is only then and not before that the true system will be arrived at."

But now other competent scientists come and show that this method not only postpones the solution of the problem to a far too distant future, but has really no prospect of success whatsoever: all pontoons which natural science successively joins bring us no nearer to the opposite bank. "And even," says Schopenhauer, " if one were to visit all the planets of all the fixed stars, one would not proceed a single step in metaphysics." And not only the older generation of philosophers speaks thus, but more or less modern scientists. Dubois-Reymond speaks about the "limits of cognition of Nature," and shows that there are natural things which we cannot reach with our cognition, conception, interpretation, etc. In the 271 volume of the "Collection of Popular Lectures" by Virchow and Holzendorf, a Dr. Töpfer declares: "We, of course, know that with the assumption of atoms the nature of matter is not defined. But the scientist does not consider it his business to define the nature of matter. He adheres to facts and humbly acknowledges that the human mind has limits set to it which it can never overstep."

One could quote any number of passages from contemporary literature stating what an absolute gulf there is between ordinary cognition of Nature and the meta- 
physical craving. This means that the confusion on the question: Where is Light to be got from? is endless. But a truly classical piece of confusion is given to us by F. A. Lange in his "History of Materialism." Apart from the numerous secondary beauties and excellent qualities of the work, apart also from the democratic kinship of the author with Social-Democracy,- things which we gladly acknowledge - the philosophic standpoint of Lange is the most pitiful exhibition of convulsive struggling in the metaphysical noose that has ever been seen. Indeed, it is precisely that continual swinging to and fro which lends the work its chief importance, since though no problem is solved and nothing is decided, it places the problem in such a clear light as to bring the final solution unavoidably near.

And now come opponents like Dr. Gideon Spieker ("On the relation between natural science and philosophy") and point to those convulsions and abuse their justified criticism in order to discredit with Lange at the same time the conception of materialism. Thus, not only the eternal, the metaphysical craving, but the real need of the present day demands that we should advance beyond the practical materialists. These people simply dismiss the question of the nature, the substance and the limits of cognition, and go on with their building of scientific pontoons, not seeing or not wishing to see, that one may, of course, be carried away by the stream, but that it is impossible to arrive at the opposite bank, where the metaphysical infatuation dwells.

Materialism, which has learned to practice the knowledge and interpretation of the most varied scientific matters, has failed up till now to explain the matter of cognition, and therefore, even its sympathetic historian was unable to gain from it a decisive preponderance over, 
the idealistic ruins. The faculty of cognition or interpretation is the only force which is still being deified. It is of the world, and yet must not be worldly, physical, mechanical. What, then, is it? Metaphysical! And none is able to explain what that means. All the definitions which we get are negative. The metaphysical is not physical, not palpable, not conceivable. What else can it be but an emotion which the happy idealists carry about with them without knowing where it is?

Man wants to know everything, and yet there is something which cannot be known, or explained, or conceived. Then one resigns himself to one's fate and points out the limitation of the human understanding. "There are two points," says Lange, "where the human mind fails. We are not able to understand the atoms and we cannot explain out of the atoms and their movement even the slightest manifestation of consciousness.

One may turn and twist the idea of matter and its forces as one likes,- one invariably reaches a residuum which is inconceivable. . . . Not without justification, therefore, Dubois-Reymond ventured to assert that our entire knowledge of Nature is in reality not knowledge, but a substitute of an interpretation. . . . This is the point which the systematisers and apostles of a mechanical view of the world pass by heedlessly,- the question of the limits of the cognition of Nature." (A. Lange, "Geschichte des Materialismus, 2 vol. p. 148-1 50.)

This, with its exact reference to chapter and verse was, properly speaking, superfluous, since the phrase is thoroughly well known. It is not only Lange who speaks thus, but also Jürgen Bona Meyer and von Sybel. Also Schäffle and Samter would speak in a similar strain were they to render an opinion. In fact, the whole ruling world speaks thus, - so far as it has advanced beyond the 
Capucines. The Social-Democrats, however, were known to Lange insufficiently,-else he would have known that in regard to this point, too, the mechanical view of the world had been completed by them.

The reader may well stop and consider where it would lead if our knowledge and cognition, if the mental instrument which during the last few centuries has been applied with so much success by science should be a mere "surrogate." Where is, then, the honest John? And if we were to look through all the big folios of philosophy, we should still not find any positive answer to it, since it were precisely the philosophers who have so far destroyed the belief in a personal ruler of heaven and earth. The unphilosophical, the religious world really had somewhere in excelsis a true fund of Reason which had lent some slight breath to a piece of dirty clay. These people were, therefore, justified in distinguishing the holy mind from the profane, the genuine from its surrogate. But how can such distinctions be upheld by those who had left the great spirit-in-chief way up in the clouds to the ignorant back-woodsmen, passes my comprehension.

“The great step backwards, made by Hegel, as compared with Kant," says Lange, "consists in that he entirely lost the idea of a more general way of knowing things than the human one." Thus Lange deplores that Hegel did not speculate about any superhuman knowledge, and we reply to it by saying that the reactionary cry: "Back to Kant!" which at present is heard everywhere, arises from the monstrous tendency to put back the clock of science and to subordinate the human knowledge to a "more general way of knowing." One would like to abolish the dominion over Nature which mankind has so far won and to get for the old bogey- 
man the crown and sceptre out of the lumber-room to reestablish the reign of superstition. The philosophic current of our time is a conscious or unconscious reaction against the visibly growing freedom of the people.

The metaphysical idea of the "limits of cognition," which runs through all the chapters of Lange's famous book and which is accepted wholesale by the learned men of the age, need only to be examined a little closer so far as its contents go in order to reveal itself immediately as a conglomerate of empty phrases. "The atoms cannot be understood, nor is consciousness to be explained." But the whole world consists of atoms and consciousness, of matter and mind. If the two are unintelligible, then what is there left for the human reason to understand and to explain? Lange is right,- properly speaking, nothing. Our ideas are in reality not ideas, but substitutes. Perhaps, the grey beasts, commonly called asses, are mere asinine substitutes and the genuine asininity is to be looked for among the higher organized creatures. I have already characterized elsewhere philosophy as a science which seeks a cracked and crazy sort of truth. When one starts to mistrust the language and charge it with giving things perverted names, then it is a sure sign that something has begun to crack. Listen to the following passage from the "History of Materialism": "Shall we define the idea of the true, the good, the real, etc., in a sense that we call that true, good or real which is so to mankind or shall we imagine that what man regards as such is also and to the same extent valid for all thinking beings that are and may be?"

We reply to this definitely and simply: As truly as that is true folly which language calls folly, so it is a perversion to imagine that the true, good, real or thinking being can elsewhere be constituted differently from 
the one which our language terms as true, good, real or thinking being. And the metaphysical water, too, must be thoroughly wet, since what is not wet cannot be called water. We certainly do not know how many strange kinds of trees may yet be found in Central Africa, but so much we do know with the apodictical certainty of Kant that the boards which are cut out of trees, may the latter grow on the planet Mars or Jupiter, cannot look, cannot make themselves felt to the touch, cannot taste the same as beef. The reader will forgive the drastic comparison, - but whenever the metaphysical craving begins to confuse the language, patience comes to an end.

Our experiences, observations or "phenomena" are classified by our faculty of cognition and by our language and designated by names. So long as the future changes are not essential, that is, so long as the movement of Nature keeps within the limits as fixed by conception and language, everything remains as before. But if and as soon as the future changes overstep those limits, so that the true, the good, the thinking beings, boards or beef or knowledge appear substintially different, then they have become different things and we require new names for their designation.

The light of knowledge makes man the master of Nature. With its assistance he is able to produce in the summer the ice of winter and in the winter the fruits and flowers of summer. But withal the mastery over Nature remains limited. Everything that is possible to do is only possible with the assistance of natural forces and given material. To desire to rule over Nature in an unlimited way by means of a mere "let there be," can only be conceived by a dreamer. Just as children and savages wish to rule unlimitedly, so do our childish scienists wish to know unlimitedly. "The system of satisfy- 
ing oneself with the given world," says Lange, "is opposed to the tendencies of unification inherent in Reason, it is also opposed to art, poetry and religion, which are possessed of the impulse to outrun the limits of experience." Well, art and poetry are known as fancies, though beautiful and adorable ones; and if religion and the metaphysical impulse do not wish to be more than to subsist and to belong to the same category, no reasonable man will object. Man is quite entitled to his metaphysical impulse to outrun all limits if he only recognises that it is not a scientific impulse. The light of Reason has certainly its limits, the same as everything else, like wood and straw, like mechanics and understanding,that is, rational limits which every part of the Universe must have if it does not want to be a piece of folly.

As man can do everything, so can he know everything - within rational limits. We cannot create like God who made the world out of nothing. We must keep to the given, to the forces and matter extant and reckon with their properties. To direct and to guide them, to shape them - that is what we call creating. To arrange and to order the existing material, to generalise or to classify, to abstract mathematical formulas from the natural phenomena - that is what we call knowing, understanding, explaining.

Our entire mental illumination is accordingly a formal procedure, a mechanical process. Just as in technical production the natural phenomena are bodily transformed, so should in science the transformation be done mentally. Just as production leaves the exaggerated craving for creation unsatisfied, so in the last instance science or "knowledge of Nature" leaves the exaggerated craving for causation unsatisfied. But as little as a reasonable man will deplore the circumstance that we need material 
in order to produce and that out of nothing and of pious wishes nothing can be made, so little will anybody who has grasped the nature of knowledge wish to outrun the limits of experience. We want material both in order to know and to explain as well as in order to produce. Therefore no cognition can enlighten us as to where the material comes from or begins. That is: material is antecedent to thought. The phenomenal world or the material is the primary thing, the substance which has neither a beginning nor an end, nor an origin. The material exists and the existence is material (in the wider sense of the word), and the human faculty of knowledge or consciousness is a part of that material existence, which like all other parts can only exercise a definite, limited function, the cognition of Nature.

When Schopenhauer wanted to have "introduced" to him the "whole company," he did not consider that the introduction is merely a ceremony and that every ceremony of introduction presupposes an unknown company. Just as "introduction" can only take place in the world of men, so is cognition only possible in the world of experience. The metaphysical impulse wishes to reverse that order, it wants to proceed with its knowledge beyond the nature of knowledge - to leave its own skin or to pull itself by its own hair out of the mire, like Münchhausen. It is only those whose ears still resound with the eternal music of religious flutes and who have, therefore, no taste for the vicissitudes of the world, that can think of such a desperate undertaking.

Lange has aptly remarked that the relation between names and things, the definitions have caused the philosophers an immense amount of trouble, but he does not notice that he himself is continually struggling in the same noose. Words or names denote always a whole 
genus of varieties. Blacks and Whites, Russians and Turks, Chinese and Laplanders are all included in the name of men. But as soon as a variety leaves its genus, as soon as it becomes more than formally different, its genus-name ceases. That is why no thing can proceed beyond its general nature, beyond its definition. Why should it be otherwise with the intellect? Does it, or does knowledge no longer belong to the phenomena, to the mundane things? It is only where there are two worlds, one a perceptible world and the other a higher, a religious or metaphysical world, that one can believe in the higher nature or origin of consciousness. But in that case there is no reason why the impulse of the higher nonsense should be limited at all. Why should not tin, board and beef also be deified, along with cognition? It is the business of Socialists to show that also the last and the most subtle metaphysical residuum of "something higher" is only fit, together with the most antiquated ridiculous superstition, for the lumber-room.

* $* \begin{array}{llllll}* & * & * & * & * & *\end{array}$

The world offers nothing but forms, changes or transformations. Those to whom that is not sufficient, should seek the eternal beyond the stars, as religion does, or beyond the phenomena, as philosophy does. The "critical " philosophers, however, have faintly felt that what is thus being sought is a crazy notion which instruction has to remove from the head of man. They have, therefore, given up the inquiry after the substance and turned their attention to the organ of inquiry, to the faculty of cognition. There they have worked quite critically. If formerly there dwelt something higher behind every bush and tree, it has now.- at least in authoritative circles - been driven to its last privacy, beyond the un- 
knowable atoms, beyond the still less knowable consciousness.

It is there you find "the limits of cognition," and there is also the crazy notion. To emancipate oneself from it is the more difficuit since the demands of the working class have driven our official scientists to pursue a conservative, a reactionary policy. Now they show themselves obdurate, they want to perpetuate the evil and go back beyond Kant. The late Lange might have landed in this company through error; but many of his successors are mere scamps who use the words of their predecessor as a good weapon against the new generation and thus compel us to carry the critique of Reason right to the very roots.

Everything that one perceives, say the Neo-Kantians, can only be perceived through the spectacles of consciousness. Everything which we see, hear or feel, must come to us through the medium of sensation, that is, through our soul. Consequently, we cannot perceive the things in their purity, in their complete truth, but only in so far as they appear to us subjectively. According to Lange, "the sensations are the material from which the real eternal world is being built up. . . . The point in question can easily be defined. It is, to the successors of Kant, like the apple in the original sin, viz., The relation between the subject and the object in cognition." (Vol. II, p. 98.)

Thus they shift their own sin to the shoulders of the post-Kantian philosophy. Let Lange speak for himself : "According to Kant, he says, our knowledge originates in the interaction of the two (subject and object),- a proposition infinitely simple, and yet invariably misinterpreted. It follows from this view that our phenomenal world is not merely the product of our conception, but a 
result of objective actions and their subjective formation. It is therefore not what an individual may perceive thus or otherwise according to his accidental mood or faulty organisation, but what mankind as a whole must perceive through its senses and Reason, that Kant calls in a certain sense objective. He called it objective in so far as we only speak of our experience; but it is transcendental, or to use another word, false, if we apply such knowledge to things in themselves, that is, to things which exist absolutely, independently of our knowledge."

Here we have some of the brew stewed over again. It would still be tasty if it really were as homemade as it is apparently being served. If I did not know that behind the belief in transcendental objects there is hidden the source of all superstition I would not waste much time in drawing over-nice distinctions between the ordinary subjectivity as "it must be perceived by mankind through its senses and reason," and the higher objectivity of "things in themselves," I would simply leave "the things which exist independently of our knowledge" till they become perceptible to it. Now, however, when I know that the above lines conceal the desire to proceed beyond the ordinary objects in order to arrive at the belief in transcendental objects, I smell distinctly that this brew has for its basis the old distinction between sacred and profane truth. At the back of the phenomena of the world there is, forsooth, something higher or mysterious which our reason is too small, our intellect is too low to grasp, which we are unable to know even "formally," which, therefore, if we are not addicted to religious belief, we must crave at least philosophically, transcendentally.

Of course, the materialists have failed up to now to take account of the subjective element of knowledge and 
have accepted uncritically the perceptible objects as current coin. This error, forsooth, is now mended.

Let us take the world as it is according to Kant, that is, as a mixture of subject and object; but let us keep to the fact that the whole world is one mixture, i. e., a unity; let us also keep to the fact that this unity is dialectical, i. e., such as is made up of its opposite, of mixture or manifoldness. Well, there are in this manifoldness of the world things such as wood, stones, trees, clods of clay, etc., which are unquestionably called objects - I say "called" without as yet stating that they really are such. There are also things such as colors, odors, heat, light, etc., the objectivity of which is more questionable. Then there are others which recede still further, such as pains in the stomach, love and spring sensations, which are decidedly subjective. Finally there are things still more and by far the most subjective which are such in a superlative degree, like moods, dreams, hallucinations, etc. Here we are at the salient point of the whole matter. Materialism has won its case if it has to be acknowledged that dreaming, though called subjective, is an actual, real thing. We are then ready to grant our critical philosophers that wood and stones,-in short, all things which are decidedly called objects, are likewise perceived through the senses of vision and touch, that, consequently, they are not pure objects, but subjective things. We readily acknowledge that even the idea of a nure object or "thing in itself" is a squint-eyed idea which sees distortedly into another week of another world.

The distinction between subject and object is a relative one. Both are of the same kind. They are two forms of one being, two individuals of one species. The subject of all predicates is called the natural process, actuality, 
empirical reality or existence. Who is there to deny that his accidental mood has the same true existence as the Mont Blanc, i. e., the quality of the existence of the two is the same, though the existence of the Mont Blanc is more universally accessible than that of the mood which only exists for the individual consciousness. It is enough that it is and that it belongs with all existence to the same category. Whoever wants a more detailed proof of the objective existence of his subjectivity has only to turn to Descartes who, as is well known, ascribed the most solid existence to cogito, to thinking, to consciousness. Idealism, the entire modern philosophy, which makes a special study of the subject-matter of cognition, lives and moves in the opinion that the intellect or the conscious, thinking being is the most evident of all evidences. "Sense of Self, self-consciousness," says Lazarus in his "Life of the Soul,"-“" that most difficult idea for physiologists, is as a matter of fact for every single individual, through his inner experience, the most certain, the most firm." Well, whether it is through the inner or external experience, it is sufficient for us, if it has to be admitted that the mind is an object of experience.

"The unification-tendencies of our Reason" require from the theologians and philosophers that they should recognise "something higher" or inconceivable. The same tendencies require from us that we should conceive heaven and earth, body and soul, atoms and consciousness as the manifold manifestations of one entity, as the manifold forms of one species, as the various predicates of one subject. The obscure inconceivableness or the inconceivable obscurity of philosophy finds its complete elucidation in the linguistical relationship between the subject and the predicate. The philologists have 
long since emphasised the unity of mind and speech. Of every predicate speech makes a subject and vice versa. The color is attached to the leaf, that means, is its predicate, the leaf is attached to the tree, the tree is attached to the earth, the earth to the sun, the sun, to the world and the world finally is the last entity or subject, the only substance which is attached to itself only, is no longer a predicate and has no thing above it. That which in the terminology of the grammar is called subject and predicate is elsewhere called matter and form. Stone is a matter; basalt or flint or marble are forms. But the stone-matter, too, is but a form of the inorganic, and the latter is a form of existence. The world is the entity, the matter, the "thing in itself"; in relation to it everything else, thinking or knowing included, are predicates, phenomena or subjectivities. Thus the conceptions of subject and predicate, of matter and form, of entity and phenomenon interchange up to the largest and down to the smallest. Whatever we grasp with our faculty of cognition we grasp as part of a whole and a whole part. The understanding of this dialectics illuminates and explains to perfection the mystical impulse to seek the truth beyond the outward appearance, that is, the subject behind every predicate. It is only through ignorance of the dialectical working of the mind that this impulse can proceed so far as to crave for a subject outside of the predicates, for a truth outside the phenomenon. A critical epistemology must recognise the instrument of experience itself as experience, in consequence of which any excursion beyond experience cannot even be discussed.

When now the modern philosophers with the historian of Materialism at their head come to us and say that the world offers but phenomena and these are the objects of 
cognition of Nature and the latter has only to do witb transformations, and desire to find a higher knowledge. an eternal, essential object, then it is clear that they are either knaves or fools who do not want to be satisfied with all grains of sand of the sand-heap, but look behind all the grains for an extra sand-heap without grains. Those who have to such an extent fallen out with the vale of tears of our phenomenal world, may with their immortal soul put themselves in a fiery chariot and go up to Heaven. But those who wish to remain in this world and believe in the salvation of the scientific knowledge of Nature, should study the materialist logic. Here it is stated:

I. The intellectual kingdom is of this world only.

2. The process which we call cognition, conception, interpretation must not and cannot do anything else but classify in genera and species this world of perceptible, interconnected existence. It must not and cannot practice anything else but formal cognition of Nature. There is no other cognition than that.

But here comes the man with the metaphysical impulse who is not satisfied with the "formal cognition," and wants to know in a different way which cannot at all be defined by him. It is not enough for him to classify the experienced phenomena with the assistance of the understanding. What natural science calls science is to him but a surrogate, a poor, limited knowledge. He strives after an unlimited spiritualisation so that the things shall be resolved into pure intellect. Why cannot that dear impulse see that it puts forward an exaggerated demand? The world does not proceed from the spirit, but quite the reverse. Being is not a variety of intellect, but on the contrary, the intellect is a variety of the empirical existence. Existence is the absolute, which is everywhere 
and eternal ; thinking is merely a special and limited form of it.

If the philosopher perverts this simple fact, then it is no wonder that the world is to him a riddle. After having so perverted the relation between thinking and being that it contradicts reality, he naturally has to rake his brain over this "contradiction of thinking." But those who regard Reason as one of the natural things, as a phenomenon among and along with, other phenomena, will not require over and above "formal " science yet some higher foolish sort of knowledge; they will make the essence of things not knowledge, but life, the empirical material life of which knowledge constitutes only a part. Science or knowledge must not take the place of life; life must not and cannot dissolve in science, since it is more comprehensive. That is why no single thing can be exhaustively mastered by knowledge or interpretation. No single thing is knowable entirely, a cherry no more than a sensation. Even when I have studied the cherry in accordance with all the demands of science, botanically, chemically, biologically, etc., I only know it truthfully after I have gone through its history, after I have touched it, seen it and swallowed it. The reader must understand that the distinction I draw here between knowledge and true knowledge is quite different from that which the metaphysicians draw. We may very well distinguish between knowledge separated from life, such as is given in school, and the living knowledge which grows with and out of the material of experience. Science presupposes life and is conditioned on experience. This is what may be called rational. And if one seeks the rational in a different way, if one wishes to get pure, unconditioned knowledge, then he may just as well look out for square circles, or iron wood, or other similar nonsense. When- 
ever a person wishes to proceed beyond the natural limits of things - and the thing termed cognition is no exception - he proceeds beyond the limits of language and reason, and black becomes white and reason unreasonable.

The wretched philosophical criticism which prevails today represents the human mind as a poor beggar which can only explain the superficial phenomena of things. True knowledge is closed to it, the essence of things is considered inscrutable. In reply to that we may ask whether each thing has its special essence, whether there is an endless number of essences, or whether the whole world is but one single unity. Then it will be seen that our mind possesses the faculty to connect all things, to sum up all parts and to divide all sums. All the phenomena are constituted by the intellect as an entity, and all entities are recognised by it as phenomena of the great general entity of Nature. The contradiction between phenomena and entity is not a contradiction, but a logical procedure, a dialectical formality. The essence of the Universe consists of phenomena and its phenomena are essential.

From this point of view the metaphysical craving or the impulse to seek an entity behind every phenomenon may live and flourish so long as it recognizes the "formal cognition of Nature" as the only rational practice of science. The impulse to go beyond the appearance towards Truth and Essence is an excellent and scientific impulse. But it must not exaggerate; it must know its limits. It must look for the sublime and divine amidst the earthly transiency; it must not separate its truth and essences from the phenomenon; it must only search after subjective objects, after relative truth.

On that the old- and neo-Kantians are also agreed; we only disagree with the melancholy resignation, with 
the sad squint at a higher world with which they accompany their teaching. We do not agree that the "limits of cognition" should again become limitless by sending belief in search of an unlimited Reason. Their reason says: "Where there are phenomena, there must also be something transcendental which appears." And our critique says, The Something which appears is itself a phenomenon, the subject and the predicate are of the same species.

With the light of cognition man illuminates all things of the world. In order that he may use it properly and avoid jugglery, it is necessary to know that the light of cognition is a thing like other things. Darwin's theory of the origin of species, which shows the gradual descent of one from the other, must also be applied here. The monistic conception of the world of the naturalists - the latter in the narrower sense of the word - is insufficient. And even if Haeckel should prove the "Perigenesis of the Plastidule" up to the hilt, even if the rise of the organisms from the inorganic should be demonstrated in the most evident manner, there will still remain the metaphysical loophole: the great opposition between mind and Nature. It is only through the dialectic-materialist. theory of cognition that our conception becomes monistic. As soon as we only grasp the relation between subject and predicate in general, we cannot fail to see that our intellect is but a variety of form of the empirical reality. Materialism, it is true, has long since put forward that cardinal proposition, but it has remained a mere assertion, a mere anticipation. To establish it on a sure basis it is necessary to gain the general conviction that science altogether does not want and cannot want to accomplish more than the classification of the perceptible things according to species and varieties; its entire desire and 
ability is confined to the mental reconstruction of the different parts of a differentiated unity.

No doubt, in case of other objects not much is said of them when it is proved that something belongs to the general order of things. One wishes to know something more specific than that, as for instance, whether it is organic or inorganic, whether matter or force, plant or animal, etc.: that it is natural, is here beyond dispute, but in the case of the mind, which for thousands of years has been the object of edification, of which people do not know how transcendentally they should extol it, a great deal is said when it is stated that it is but a variety, a form, a predicate of Nature, that it must be such since the linguistic unity of word and meaning admit of but one Nature. Just as necessarily as water is wet so necessarily has each thing which has a nature - and how can one conceive of anything which has no nature of some kind - the very same natural nature. The word and its meaning allow of no other nature.

The savage makes a fetish of the sun, the moon and other things. The civilized nations have made a God of the mind, a fetish of the faculty of thinking. This must cease in the new society. There the individuals live in dialectical community: the many in unity; and the light of cognition will also have to moderate itself and be content with being a force among other forces, a tool among other tools. At the same time, however, it must claim that it is truly what it is. Human cognition has no cause to feel that disgracefully humble modesty which the Professors Nägeli and Virchow wanted to ascribe to it. They have cunningly spoken of the limits of cognition, because the will-o'wisp of a " higher" unlimites cognition has been playing pranks with them in tne metaphysical darkness.

* $*$ * $* * \quad * \quad * \quad * \quad * \quad * \quad * \quad * \quad *$




$$
\text { - }
$$




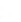




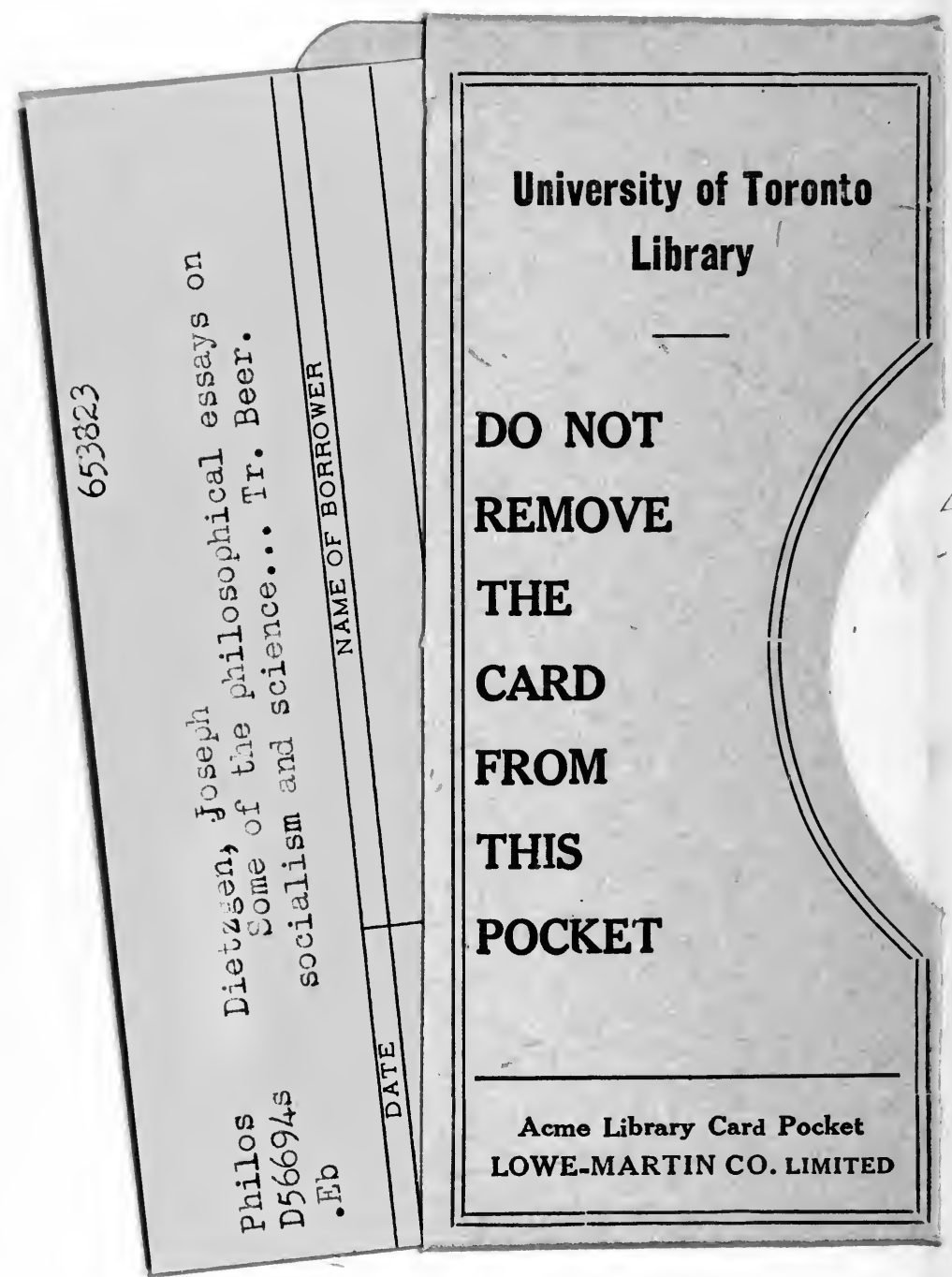


